\title{
متطلبات تطوير الميزة التنافسية لجامعة أسوان في ضوء الاتجاهات العالمية المعاصرة
}

\author{
إعلاد \\ دا حا تم فرغلي ضاحي \\ مدرس بقسم أصول التربية -كلية التربية - جامعة أسوان \\ Email: hatemdahy1973@hotmail.com
}


متطلبات تطوير الميزة التتافية لجامعة أسوان في ضوء الاتجاهات العالمية المعاصرة

$$
\begin{aligned}
& \text { إعداد } \\
& \text { د. حانم فرغلي ضـاحي } \\
& \text { مدرس بقسم أصول التزبية } \\
& \text { كلية التربية - جامعة أسوان }
\end{aligned}
$$

Email: hatemdahy1973@hotmail.com

\section{المستخلص :}

استهدف البحث التعرف على متطلباث تحقيق الميزة التتافية لجامعة أسوان

في ضوء الاتجاهات العالمبة المعاصرة، و اعتمد البحث على المنهج الوصـفي ، و و

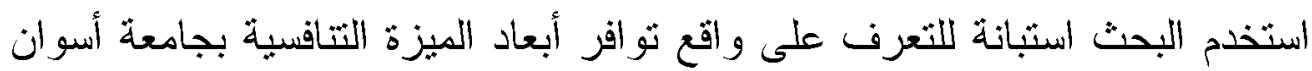

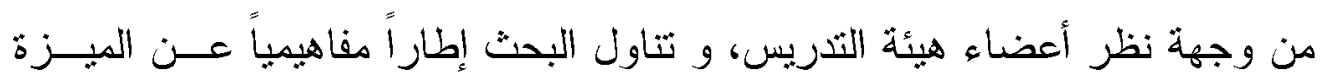
التنافسية الجامعية من حيث المفهوم و الفسلفة و الأهـــاف و الأبعــاد و مثطلبــات

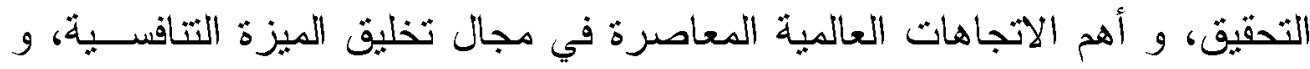
توصلت الدراسة إلى نتائج أهمها: تحقق معظم أبعاد الميزة التتافسية لجامعة أســـوان بصورة جيدة، مع وجود ثصور في تحقيق بعض منطلبات ضمان الجودة والاعثماد، و في النهاية ثوصل البحث إلى مجموعة منطلبات لنطوير الميزة التنافسية بجامعسة - أسوان الكلمات المفتاحية: الميزة التنافسية الجامعية - الاتجاهات العالمية المعاصرة 
متطلبات تطوير الميزة التنافسية لجامعة أسوان في ضوء الاتجاهات العالمية المعاصرة

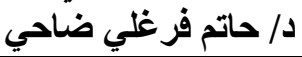

\title{
Requirements for developing the competitive advantage of Aswan University in light of contemporary global trends
}

\author{
By \\ Dr. Hatem Farghaly Dahy \\ Teacher in the Department of Education Origins \\ Faculty of Education- University of Aswan \\ Email: hatemdahy1973@ hotmail.com
}

\begin{abstract}
:
The research aimed to identify the requirements for achieving the competitive advantage of Aswan University in the light of contemporary global trends, and relied on the descriptive approach, and the research used a questionnaire to identify the reality of the dimensions of the competitive advantage at Aswan University from the viewpoint of faculty members, and the research dealt with a conceptual framework on the feature University competitiveness in terms of concept, philosophy, goals, dimensions and requirements for investigation, and the most important contemporary global trends in the field of creating a competitive advantage, and the study reached the most important results: Most of the dimensions of the competitive advantage of Aswan University are achieved well, with deficiencies The achievement of some of the requirements of quality assurance and accreditation, and finally reach a set of research requirements to develop a competitive advantage at the University of Aswan.
\end{abstract}

Key words: University competitive advantage - Contemporary global trends 
شهدث بدايات القرن الحادي و العشرين منافسة حادة في دول العالم أجمع و

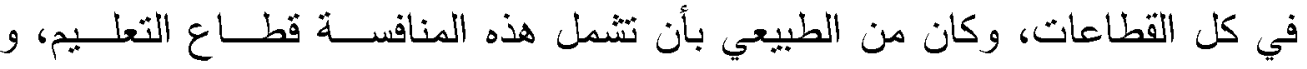

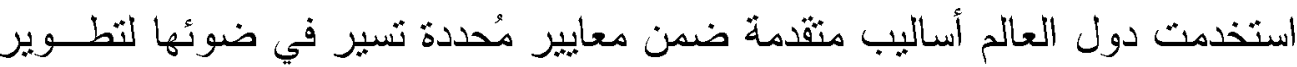
نظامها التعليمي و تقليل نكاليفه، و على رأسها الميزة التنافسية .

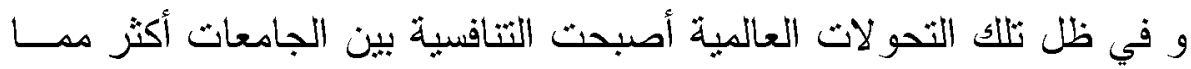
كانت عليه، فذخلت المنافسة إلى الساحة المحلية بين الجامعات الحكومية و الخاصة

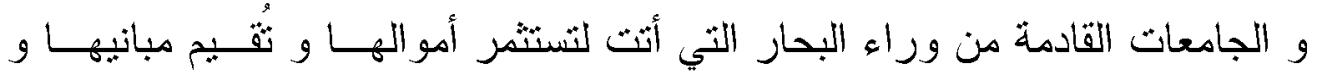
تُمارس خدماتها محلياً، أو ثلك التي تُتشئ بر امج مشتركة مع جامعات خاصة محلية، أو التي نستثطب طلاب من الداخل للسفر للالتحاق بها أو للار اسة عن بعد إلكترونياً، و هو ما جعل الجامعات ثسعى لتوظيف إمكاناتها في تخليق مزايا نتافسية تضمن لها

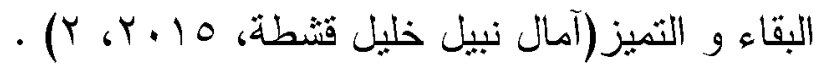
و فى ظل تداعيات العولمة و تدويل التعليم و إقتصــاد المعرفــة أصــبحت

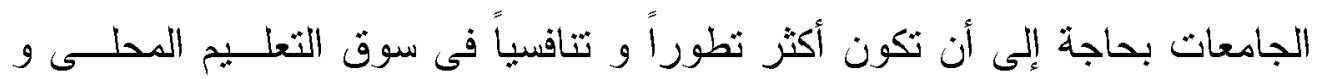

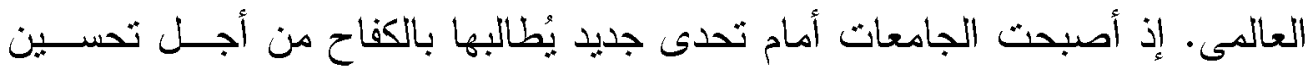

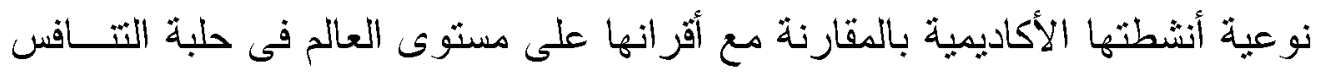

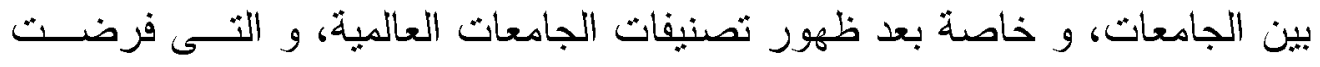
على كل جامعة العمل على صياغة استر اتيجيات لبناء و تعزيز مزاياهــا التتافسـية .(Horta, Hugo, 2009, 388, 389)

و تعني الميزة النتافسية الجامعية: "قدرة الجامعة على ثقديم خدمة تعليمية و

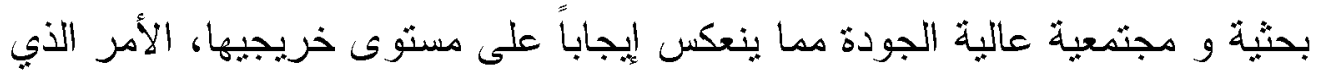
يُكسبهم مز ايا نتافسية في سوق العمل بمسنوياته المختلفة، و يعكس ثقة المجنمع فيها و التعاون معها و زيادة إقبال الطلاب على الالتحاق بها. و لذا تتسابق الجامعاث دن

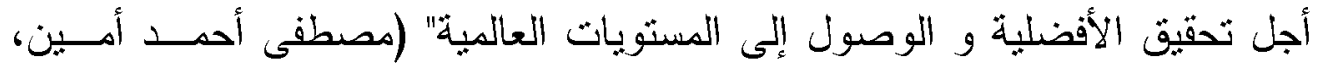
$\cdot(r), r \cdot 1 V$ 
و ثقوم تتافسية الجامعة على شقين أساسين هما: الثنق الأول: و هو قـدرة الجامعة على تحقيق الثميز على الجامعات المنافسة في مجالات حيوية مثل: البرامج

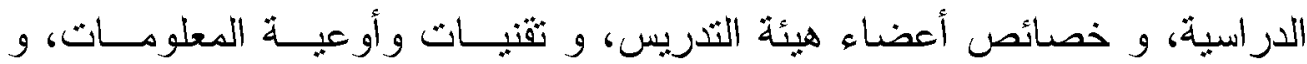

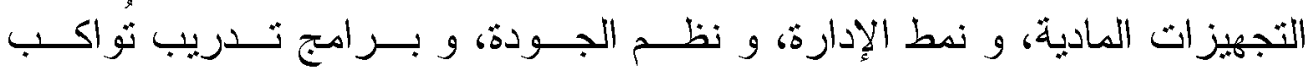

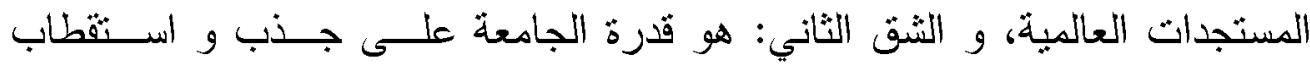
الطلاب، والثمويل من السوق المحلية والعالمبة، و بالتالي فالسباق التتافسي للتعلــيم

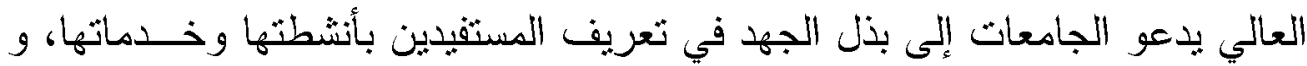
توزيعهم إلى مجموعات مستهدفة، حنى ثستطيع الجامعة دراسة رغباتهم و إثباعها

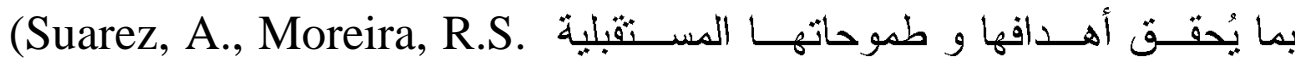

.Carrapatoso,E., 2006, 314)

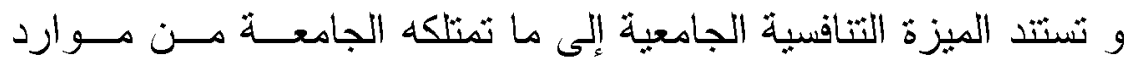

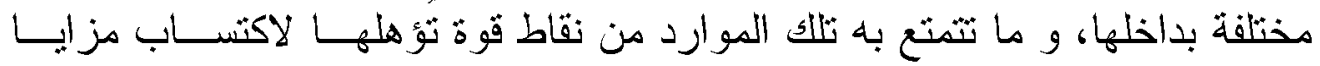
تتافسية تتفرد بها عن غيرها من الجامعات المنافسة، فتزداد بذلك قدرة الجامعة على بلى الاحتفاظ بجاذبيتها و بقاء مُساهمبها في الأجل الطويل، و تثحقق المبـزة التتافسـية

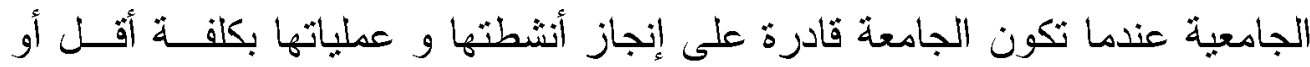
بفاعلية أفضل من الجامعات الأخرى المنافسة، و تشنطيع توفير فيمة مُضافة أكبــر

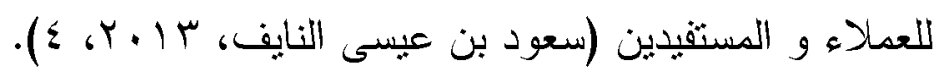

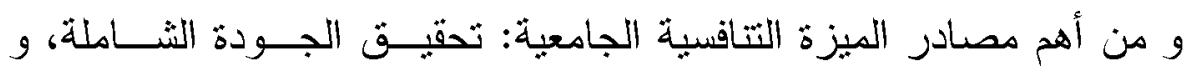
الاهتمام بالكفاءات المنميزة، و تلبية رغبات العملاء و المستفيدين، و تحفيز الابتكار،

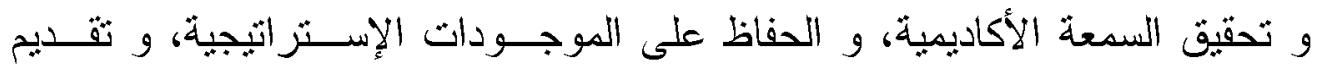
منتجات جامعية مرنة ذات كفاءة عالية، و السعي لتحقيق الأهــداف الإســتراتيجية للجامعة، و ثو افر قوة بيع فاعلة للبرامج الجامعية المتجــدةث، و تشــويق البحــوث

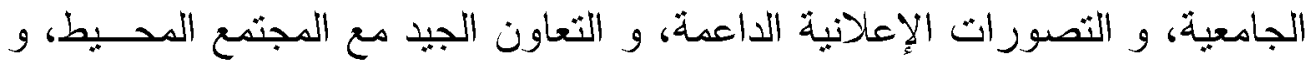
استغلال الموقع الجغر افي للجامعة، و التجديدات المتلاحقة لمرافق الجامعة، و تكوين

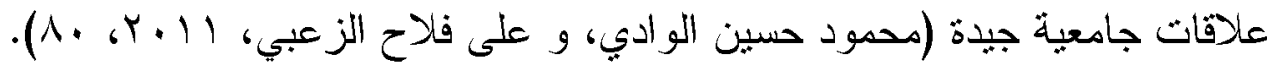


و في ظل نزابد حدة المنافسة بين الجامعات و اتساع رقعتها و تعـدد مجالاتهـا، يجب على الجامعات المصرية البحث عن كيفية تعزيز مز اباها التتافسية التي تمنحها

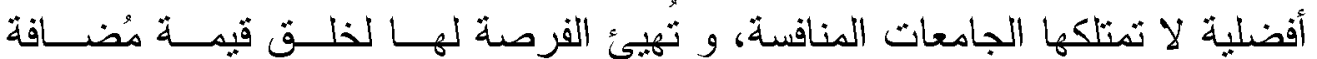
لمنتجاتها و خدماتها، و الاستجابة لرغبات العملاء و المستقبدين . مثكلة البحث: - مثن لم يكن تحقيق الميزة التتافسية في العقود الماضية هــدفاً مُلحــاً للجامعــات

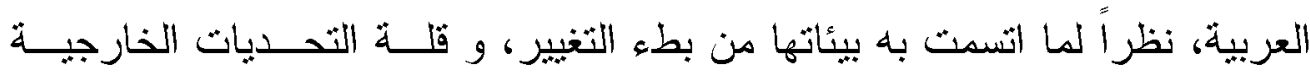

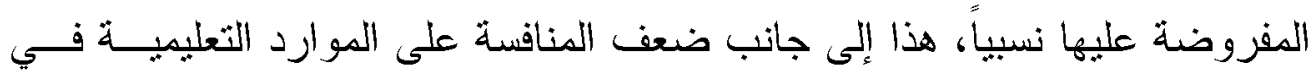
ذلك الوقت . و لم تكن هناك مُنككلات كبيرة تهدد بقاء الجامعات العربية خاصة في هي

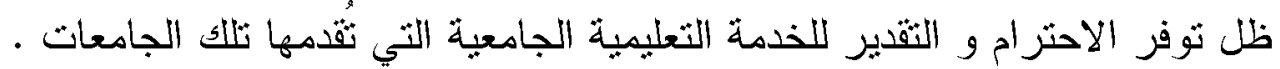
و ثو اجه الجامعات العربية العديد من المعوقات التي تُدد من قدرثها التتافسبة، و و تتقسم هذه المعوقات إلىى: معوقات خارجية: و تشنمل تحول التتافس مسـن الســلع و الخدمات إلى التتافس المعرفي، و تحول المعايير الخاصة بالجودة و الاعتمــاد هـن المحلية إلى الدولية، و وجود جامعات عالمية المستوى تثحالف مع مر اكـز بحثيــة

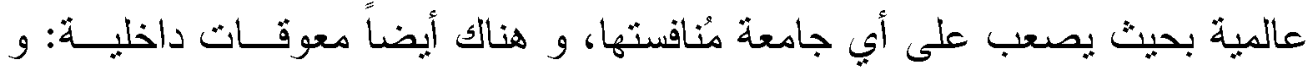
تشمل: الفجوة العلمية و التكنولوجية بين الجامعات العربية و العالمية، و عدم مُو اكبة المقررات الدراسية لمنطلبات التحديث، و نقص الكفاءات الأكاديميــة المتمبــزة، و و تز اجع أدوار أعضاء هيئة التدريس، و ضعف الاهتمام بتتمية مهــارات العـاملين،

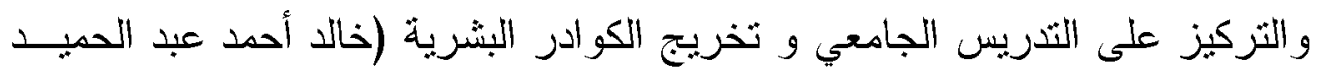

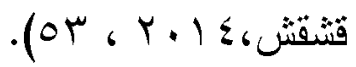

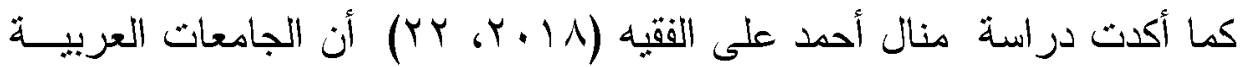

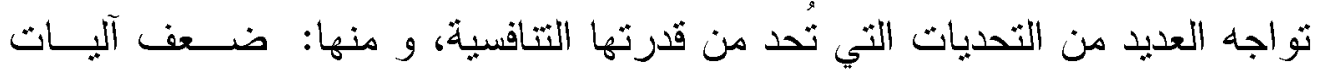

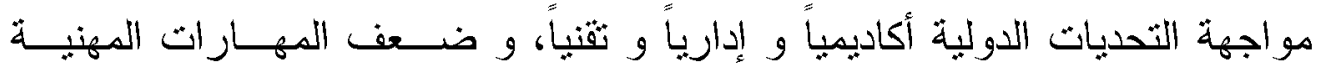

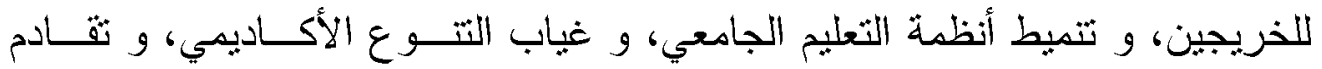

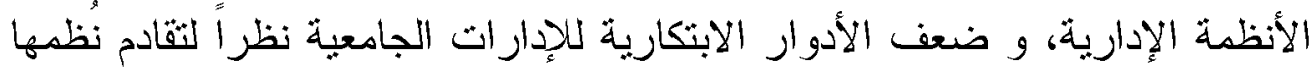


المالبة و الإدارية، و ضعف التوجه التشويقي ، و افتقاد آلبات إرضــاء العدـلاء و المستفبدين، و ندرة الموائمة الاحتر افية بين السياسات الجامعية ومتطلبـات سـوق العمل، علاوة على تراجع ترتيب معظم الجامعات العربية فــي التصــنيف الـدولي للجامعات .

و على صعيد جمهورية مصر العربية شهد التعليم الجامعي تغيرات مُعقدة أثرت على مكانته الدولية، خاصة في ظل المنافسة العالمية، و الاندماج الحادث بين الجامعات العريقة، و ظهور العديد من التوجهات المسثقبلية مثل: التدويل، و ضمان

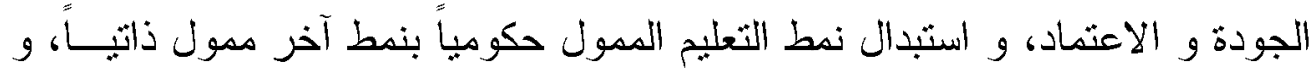
لقد تأثر التعليم الجامعي المصري بهذه التغيرات، و من دلائل خطورة ما يتعرض له له من تحديات ما كثنفت عنه الثقارير الدولية، حيث أشار تقرير التتافسية العالمي للعام

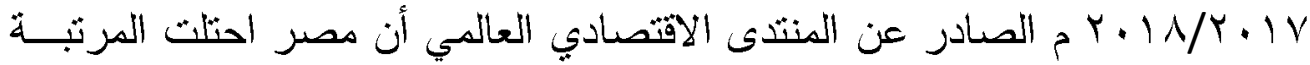

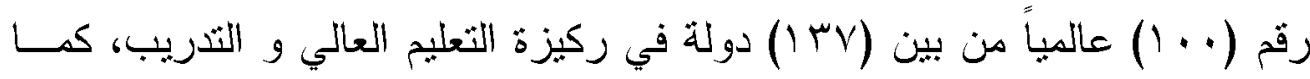

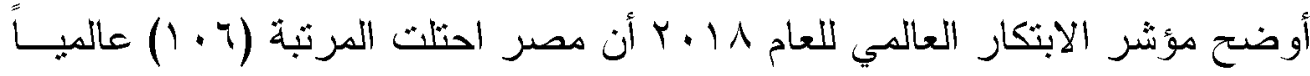
من بين (TY I) دولة في مؤشر التعليم الجامعي، و هذا يُنذر بعو اقب وخيمة فمن لا

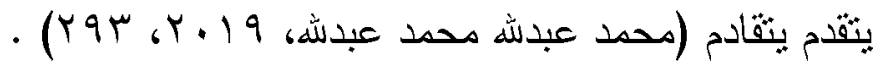

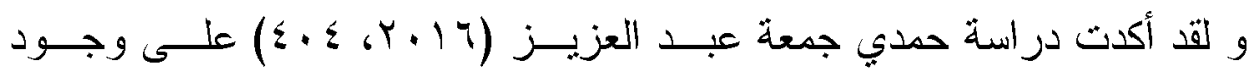
معوقات أخرى تُؤدي إلى ضعف الميزة النتافسية للجامعات المصرية، و منها: عدم الربط بين التعليم الجامعي و استراتيجيات الميزة التتافسية، وضعف كفاءة المقرار ات الجامعية، و قلة المخصصـات المالية اللازمة لاستثمار التعليم الجامعي فـي نتميــة الموارد، وضعف ثدرة الجامعات المصرية على تسويق منتجاتها البحثية، و وجــود فجوة بين البحث العلمي وتطبيق نتائجه داخل المجتمع ، كل ثلك المشكلات تُقلل من ون القدرة التنافسبة للجامعة .

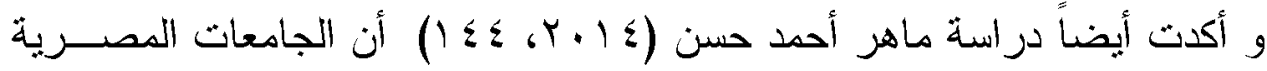
لا نمنلاك مقومات القدرة على منافسة الجامعات المنقدمة و الجامعات العابرة للحدود، و ذللك بسبب غياب تواجدها على مسنوى التميز البحثي الدولي و ضعف إمكاناتها و 
محدودية دور ها في إنثاج المعرفة و ثبادلها، و اتساع الفجوة بين قدرات خريجيها و منطلبات سوق العمل المحلية و العالمبة، و بالتالي نزاجع نرنيبها فــي التصــنيفات العالمية للجامعات

و من أهم أسباب نز اجع ترثبب الجامعات المصرية في التصنيفات العالميــة

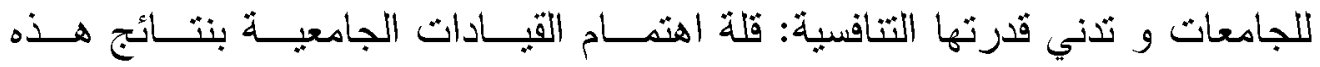
التصنيفات، و ضعف البنية التحتية التكنولوجية، و ضعف الانفاق على البحث العلمي

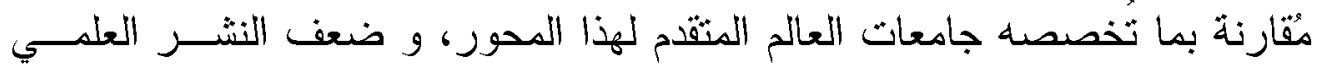

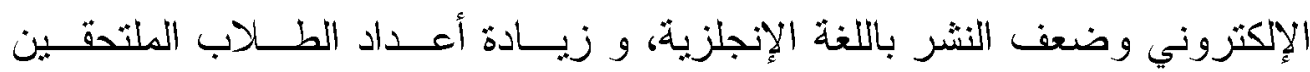

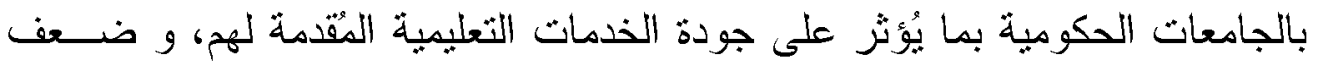

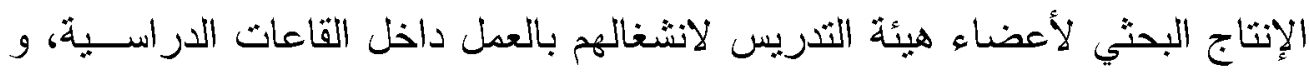
هجرة المو هوبين منهم بسبب نقص الإمكانات، و عدم استقلال الجامعات المصــرية

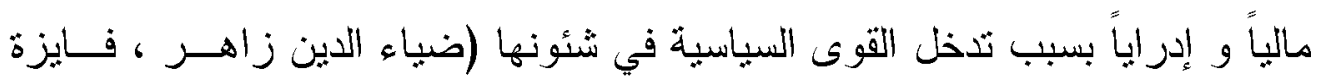

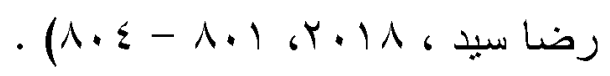

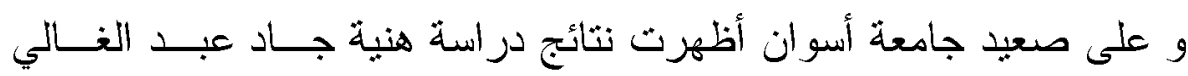

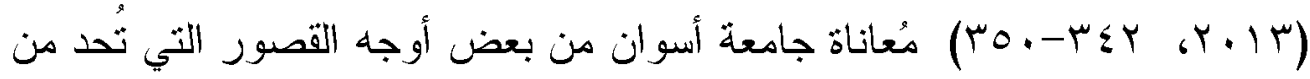
قدرتها التتافية، و أهمها: ضعف الهياكل التتظيمية، و عدم وجود منظومة للمعلومات

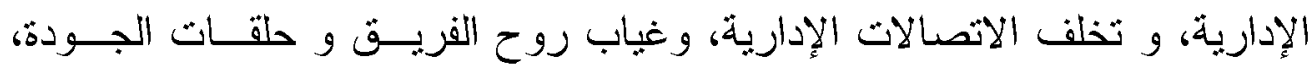

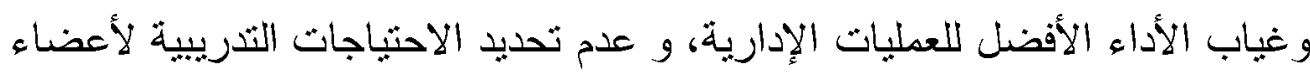

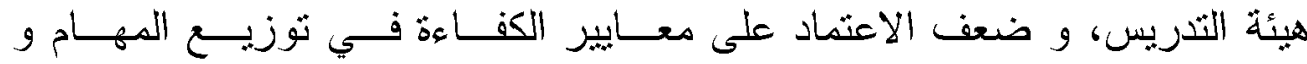

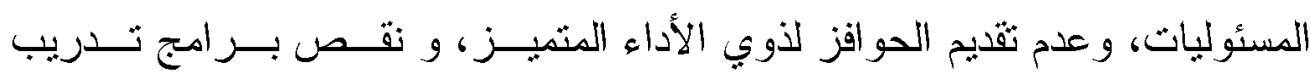
العاملين على كفايات الأداء الجامعي المنطور .

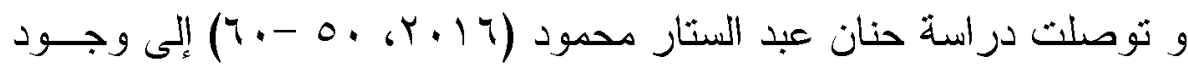
بعض المعوقاث الأخرى التي تُقلل من القدرة التتافسية لجامعة أســـوان، و أهمهـــا:

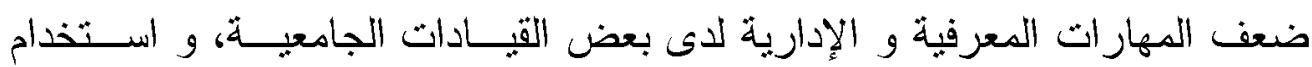

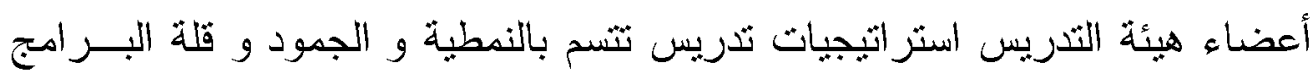


التدريبية المخصصة لهم، و عدم ثقبل الجامعة لنقافة التغيير بما تحنويه من مهارات

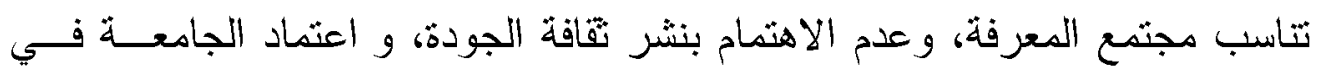

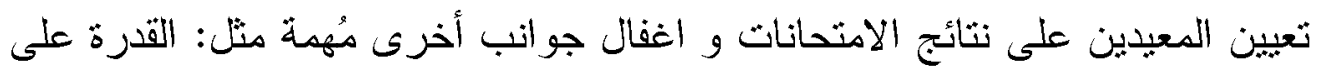
البحث عن المعلومات و تطوير المعرفة و انتاج أفكار إبداعبة . و في ضوء ما سبق تحاول الدراسة الحالية وضع تصور مقترح لإمكانية تطوير

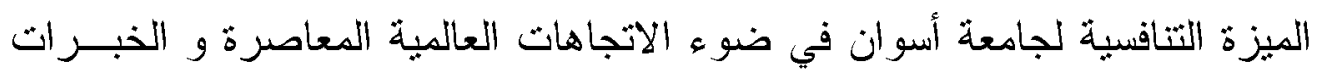
الدولية في هذا المجال ، لذا بُمكن بلورة مشكلة البحث في النساؤلات الثالية:

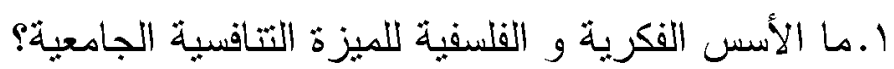

r. ما الاتجاهات العالمية المعاصرة في مجال تخليق الميزة التتافسية الجامعية؟ r.ما واقع تو افر أبعاد المبزة التنافسية بجامعة أسوان من وجهة نظر هيئة التدريس

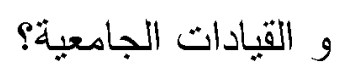

ـ. ما منطلبات ثطوير الميزة التنافسية لجامعة أسوان في ضوء الاتجاهات العالميـة

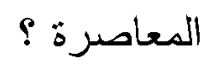

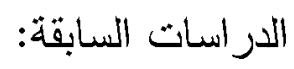

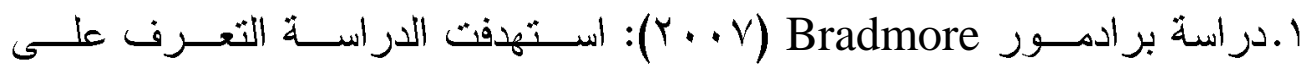

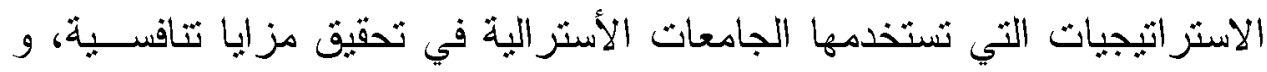

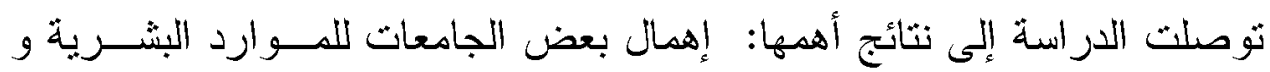
المادية، وعدم اعتمادها على منهجية و اضحة للتخطبط الإســتراتبجي فـي إدارة أعمالها بل تعتمد في قراراتها على الخبرة الثخصية، و اكتشفت الدرسة المبدانية

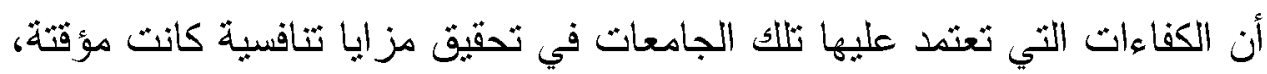
و بالثالي الميزة التتافسية المتحقة لبست مستدامة، و رغم تطبيق هذه الجامعسات لنموذج القوى الخمس لبورثز لكن لم تجد الدراسة تأثير لهذه القوى على الميـزة لهزة

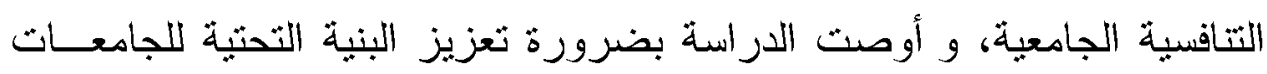

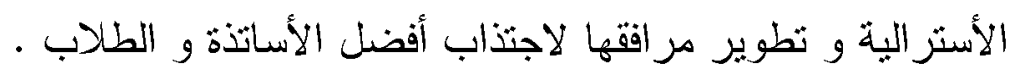


Y.دراسة عدنان الإبر اهيمي (9 . . Y): استهدفت الدراسة التعرف على درجة فاعلية

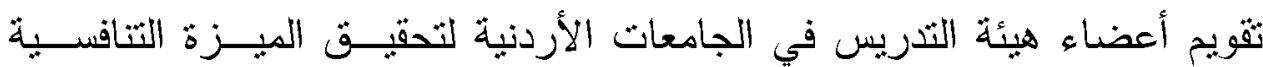

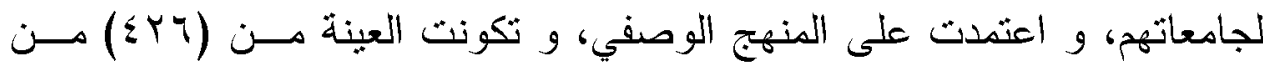
أعضاء هيئة التثريس في أربع جامعات أردنية ممن هم بدرجة (أستاذ و أســتاذ

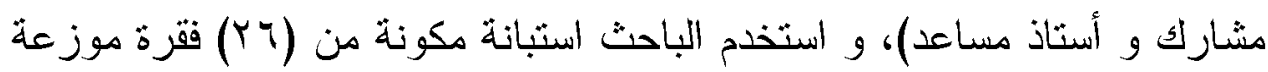
على ثلاثة مجالات رئيسية هي: الأهداف الإسنراتيجية و أهداف الجامعة و أهداف

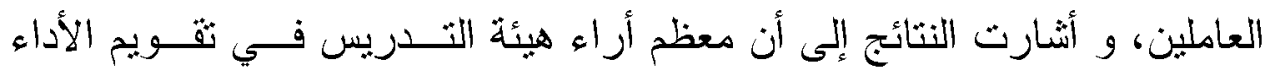
جاءت بدرجة منوسطة، و أن هناك اختلافات في تثديرات أعضاء هيئة التدريس

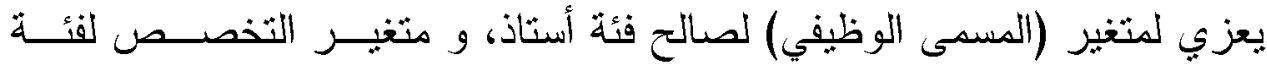
(أستاذ)، و متغير التخصص لفئة الكليات الإنسانية، و ليس هنالك اختلافات فـي تقدير ات أعضاء هيئة التدريس باختلاف الجامعة و الخبرة. ץ.دراسة Soegoto, Eddy Soeryanto (2009): استهدفت الدراسة الثعرف على أثز البيئة التسويقية في الجامعات الخاصة في منطقتي جاوا و بانتين في أندونيسيا على انخفاض إقبال الطلاب على هذه الجامعات منذ عام (ع ...Y.م) حتـى عـام

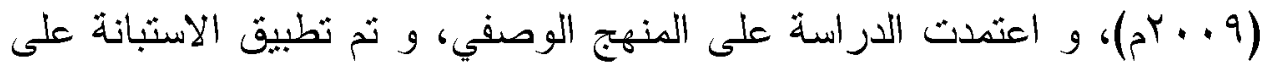

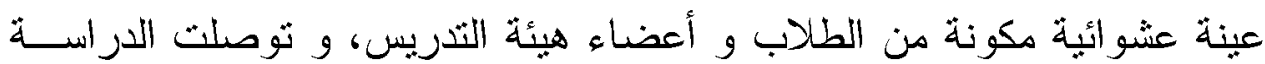

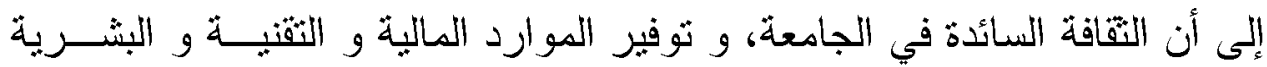

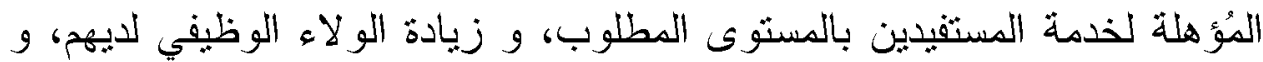
اسثقطاب عدد أكبر من الطلاب، كل هذه العو امل تُحقق مز ايا تنافسية للجامعة.

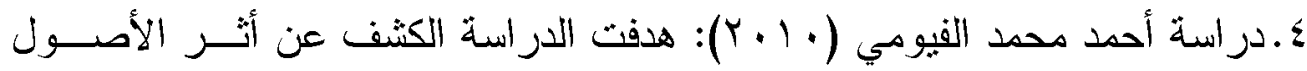
غير الملموسة (رأس المال البشرب و رأس المــال المنظـــومي و رأس المـــال المعلوماثي) في نحقيق المبزة التنافسية في ظل ثبني معايير الجودة النـاملة فـي الجامعاث الأردنية الرسمية و الخاصة، و استخدث الدراســة اسـتبانة لجمـع الييانات، و تكونت عينة الدراسة من (· (M) من القادة الأكاديمين و الإداريين في ولي الجامعاث الرسمية و الخاصة، و ثم التوصل إلى أثر لمعايير إدارة الجودة الثاملة 
في تحقيق المبزة التتافسية في الجامعات الرسمية و الخاصة، وأثز الأصول غير الملموسة في تحقيق الثميز في ظل ثبني معايير إدارة الجودة النشاملة بالجامعـات الأردنبة.

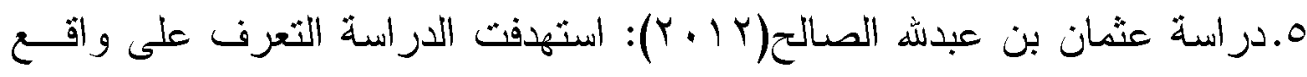
المبزة التتافسية في الجامعات الحكومية السعودية، و استخدمت الدراسة المــنهج الوصفي، و نكون مجتمع الدراسة من ست جامعــات حكوميــة، و نمثلــــ أداة

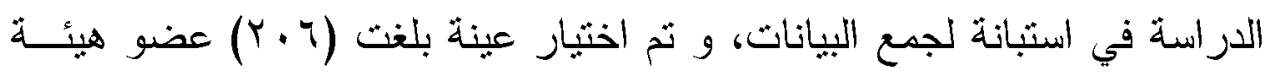

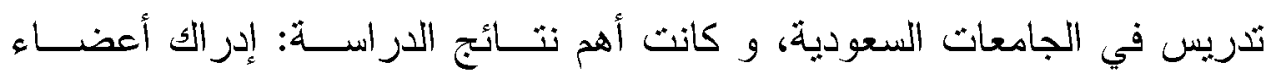

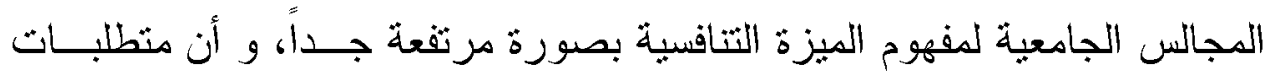

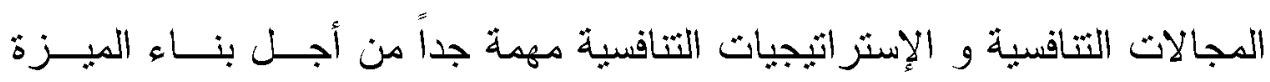
التتافسية من وجهة نظر أعضاء تلك المجالس، و عدم وجود فروق في مثوسطات استجابات أفر اد عينة الدراسة حول محاور الدراسة وفق لمنغير (سنوات الخبرة)، و وجود فروق في متوسطات استجابات أفراد العينة حول محاور الدراسة وفـق

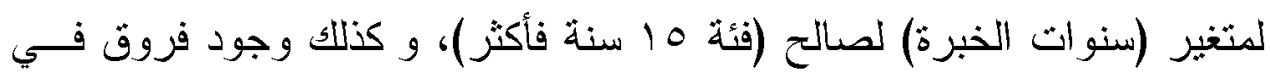
منوسطات استجابات أفراد العينة حول محاور الدراسة وفق (متغير الجامعة) .

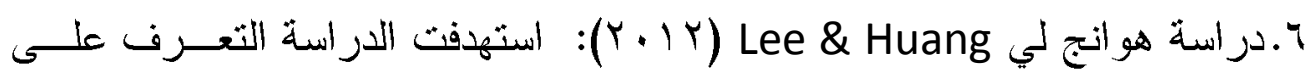

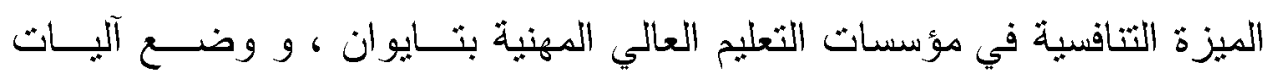
لتحقيق الميزة التتافسية بالتعاون مع القطاع الخاص و المر اكز المهنية في ثايوان،

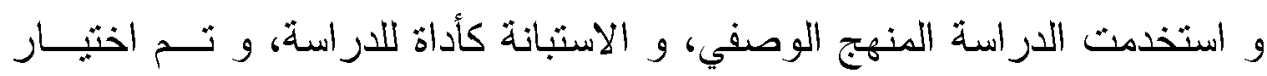

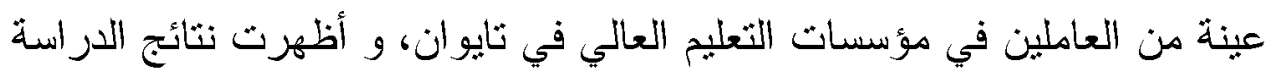

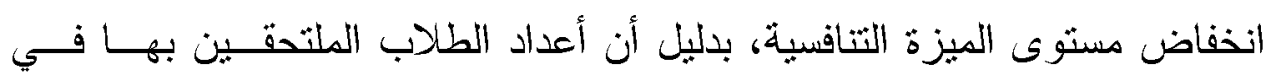
تتاقص من عام لآخر، و اقترحت الدراسة بعض الآليات لتحقيق الميزة التتافسية،

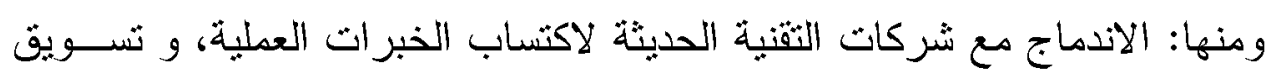

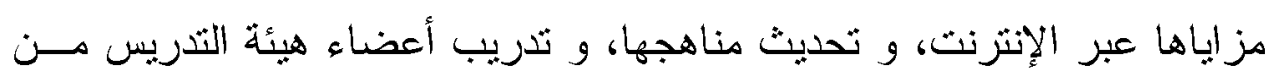

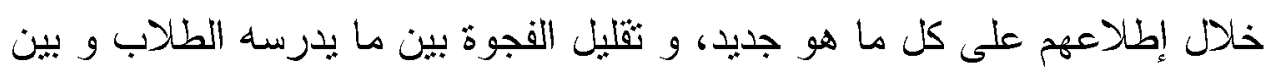


ما بحثاجه سوق العمل، و إقامة شراكات مع الجامعات المرموقة لتبادل الخبرات

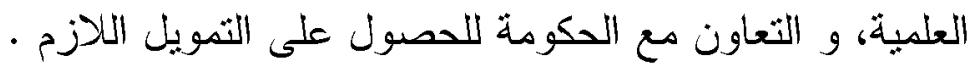

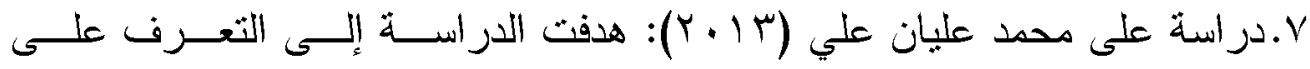
منطلبات استدامة الميزة التتافسية في مؤسسات التحليم العالي الفلسطينية من وجهة

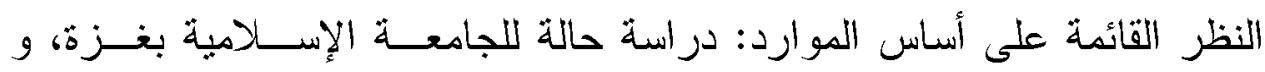
اعتمدت الدراسة على المنهج الوصفي التحليلي، و استخدمت استبانة ثم تطبيقهـا

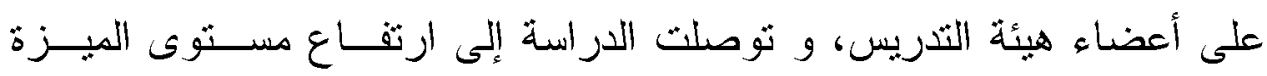
التتافسية بالجامعة الإسلامية بغزة، وأهم منطلبات استذامتها هي (ثقييم مــوارد و قدرات الجامعة، التعلم المنظمي، و التحسين المســثر، التكيــف المنظمـي، و و التركيز على أسس الميزة التتافسية )، و أوصت الدراسة بضرورة اهتمام الجامعة بمثطلبات استخامة الميزة التتافسية، و الثركيز على بناء القدرات الإستراتيجية، و و امنلاكك الجامعة موارد تثسم بالندرة للحد من قدرة المنافسين علـى محاكاتهــا، و و التحسين المستمر للبر امج الأكاديمية، و تبني الابتكارات النوعيــة، و ضــرورة

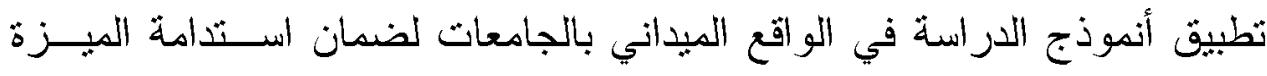
الثنافسية.

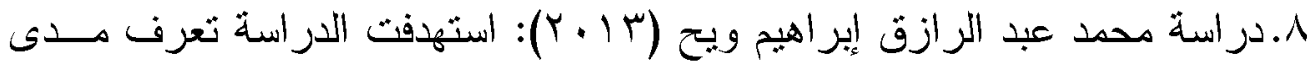
توافر رأس المال الفكري في جامعة بنها لتحقيق المبزة التنافسية لها، و اعتــدت

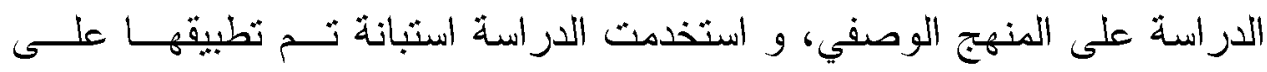

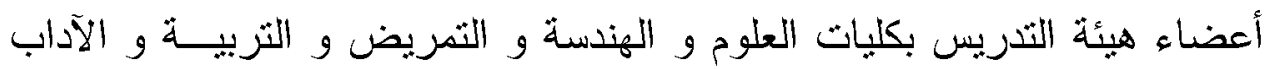

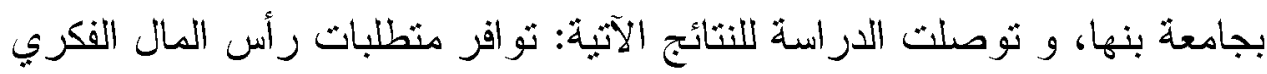

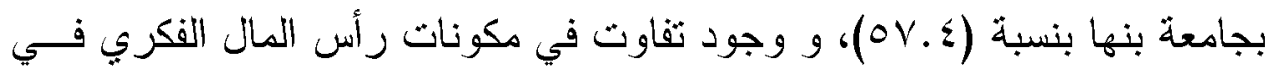
تحقيق المبزة النتافسية لجامعة بنها، و جاء ثبني الجامعة لتكنولوجيا المعلومات في وهي عملياتها التعليمية والإدارية العنصر الأكبر في تحقيث المبزة التتافسية، تلاه سعي

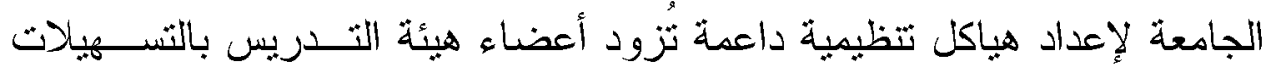

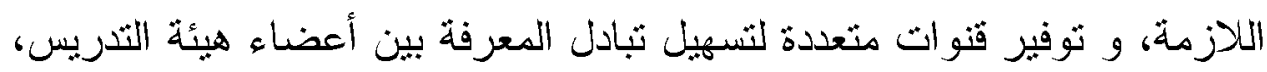


و أوصت الدراسة بضرورة تفعيل الخطة البحثية لجامعة بنها و التسويق الجيد لها في جميع الكليات، و رفع مستوى طموح أعضاء هيئة التدريس للارثقاء بأنفسهم

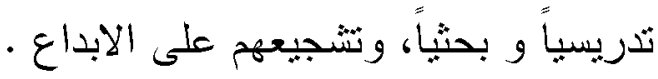

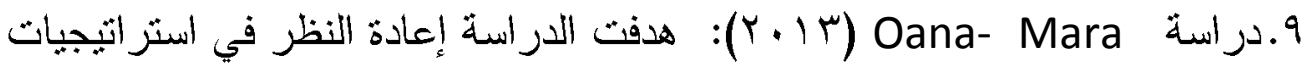
إدارة الموارد البشرية في الجامعات الرومانية عبر أعلى مسثوى في الجامعسات

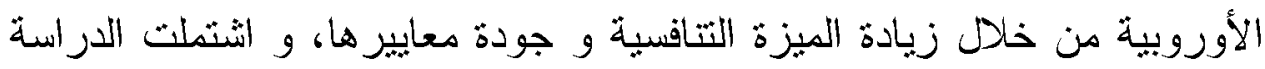

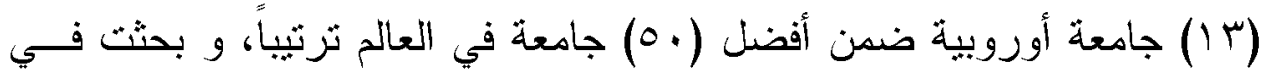

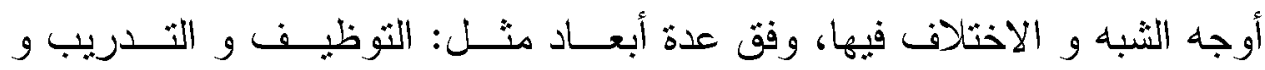

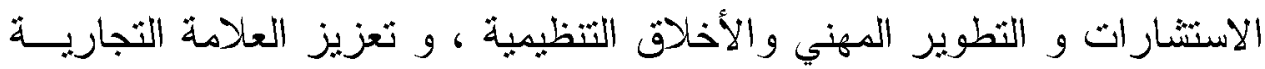

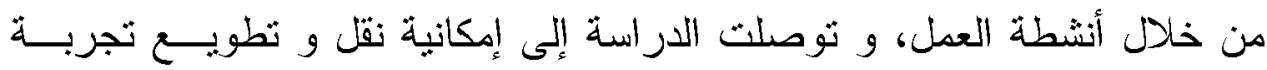

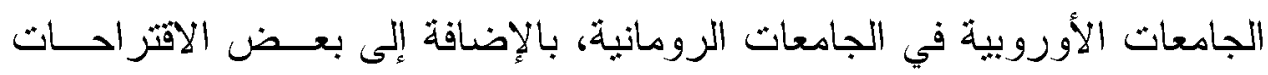
القيمة لإدارات الجامعات الحكومية و الخاصة في رومانيا لتحقيق الميزة التنافسية في جامعاتهه

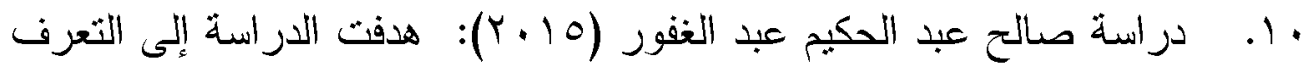

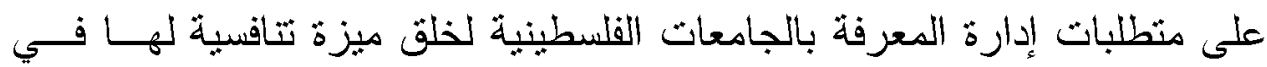
ثطاع غزة من وجهة نظر الطلاب المنوقع تخرجهم، وطبيعة العلاقة الارنباطيـة يين متغير إدارة المعرفة و عناصر مختارة للميزة التنافسية الجامعية، و اعثمدت الار اسة على المنهج الوصفي التحليلي، و استخدمث اســنبانة لجمـع الييانــات الأولية، و توصلت الدراسة لنتائج عديدة أهمها: سعي الجامعات الفلسطينية لثوفير مثطلبات إدارة المعرفة في مجموعة أبعاد كانت على الترثيب (القوى البثــرية،

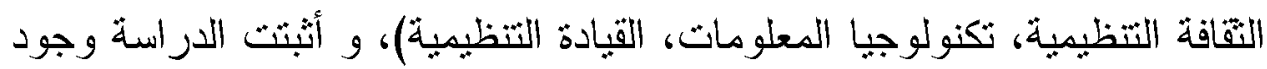
علاقة قوية بين تلك المنطلبات و تحقيق مز ايا تتافسية، و أوصت الدراسة بضروة وهية تو اصل الجامعات مع الطلاب لتبادل الأفكار و المعلوماث، و أن ثتقبل النقد البناء للارتقاء بالجامعة، و تفهم الجامعة للظروف المالية للطلاب، و نشر ثقافة الجــودة بين العاملين بالجامعة، و تطوير قدراتهم من خلال مزيد من التدريب . 


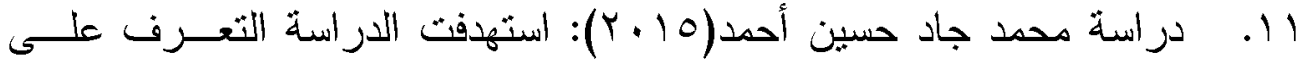
منطلبات تطبيق Six Sigma بالجامعة و علاقتها بتحقيق الميزة التتافسية بـبعض

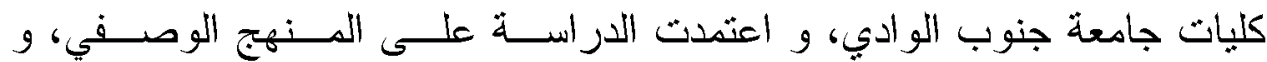
استخدمت استبانة تم تطبيقها على كل من أعضاء هيئة التدريس و العاملين بكليات (العلوم و الزر اعة و الهندسة بقنا) ، و ثوصلت الدراسة إلى أهم منطلبات تحقيق هن مدخل ستة سيجما بالجامعات، وهي: دعم الإدارة العليا بالجامعة، و ثو افر البنيــة التحنية اللازمة لنطبيق هذا المدخل الإداري، وتطوير الثقافة التنظيمية بالجامعة،

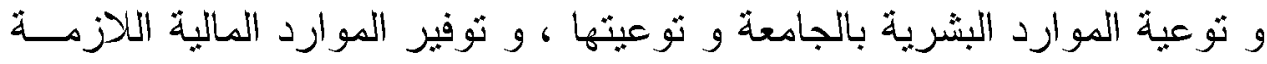

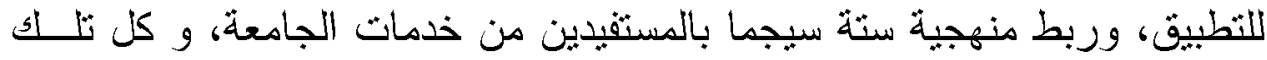
الأبعاد على علاقة ارتباطية بأبعاد الميزة التتافسية (التكلفة، و الجودة ، و المرونة

$$
\text { و الإبداع). }
$$

Y 1. دراسة يوسف رزق عبدله السوسي (10 ب): و هدفت الدراسة إلى الكثّف

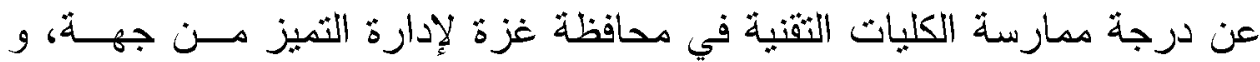

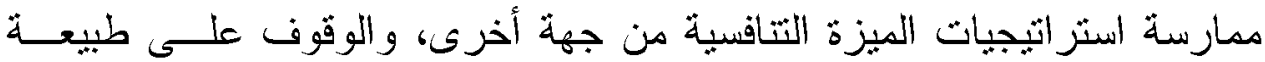

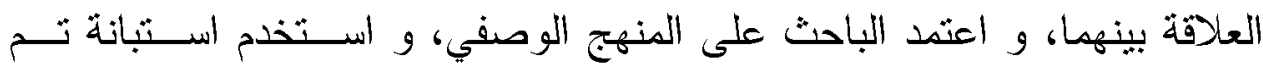
تطبيقها على مجموعة مُمثلة من العاملين في الكليات الثقنية ، ومن أهـــــــــائج الار اسة: درجة ممارسة الكلبات التقنية في محافظة غـزة لاســـر اتيجية المبـزة التتافسية من وجهة نظر الهيئة الإدارية و الأكاديمية فيها حصلت على وزن نسبي

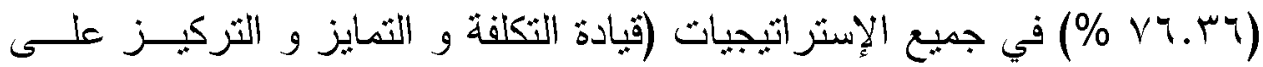
خدمة الطلاب)، و أوصت الدراسة بإجراء تغييرات في الكليات التثنية، و تحسين

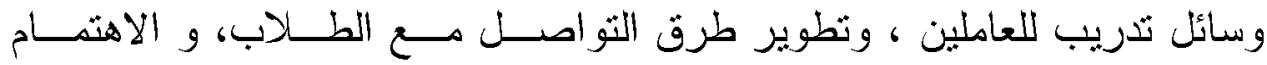

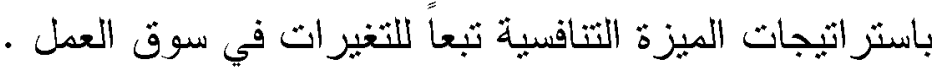
با ا. دراسة منال رفعت مصطفى غنايم (10 ـ ب): استهدفت الدراسة بناء تصـــور

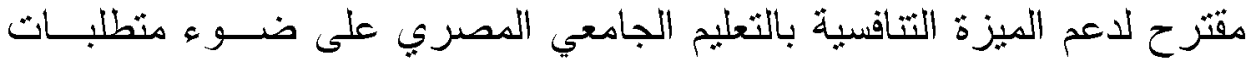

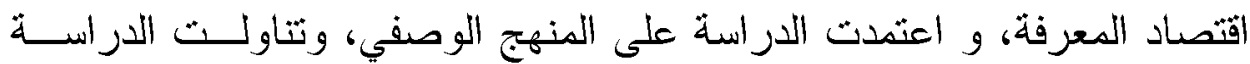


إطارًا نظرياً حول الميزة التتافسية من حيث المفهوم و أساليب التحقق ومعـايير

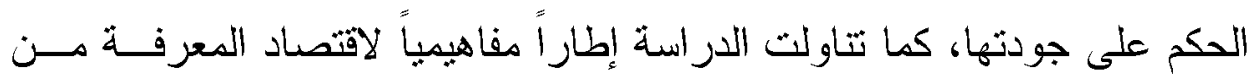
حيث المفهوم و السمات و المتطلبات، وتتاولت الباحثة دراسة نظرية لمدى تو افر مثطلبات اقتصاد المعرفة بالجامعات المصرية، وانتهت الدراسة بثقديم تصــور مقترح لدعم المبزة التتاقسية بالتعليم الجامعي المصري على ضـــــ منطلبــات اقتصاد المعرفة .

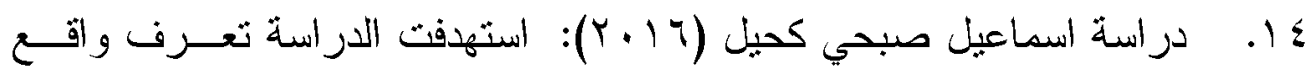
إدارة الجودة الثشاملة في جامعة فلسطين و علاقته بمســتويات تحقبــق الميـزة التتافسبة للجامعة، و اعتمدت الدراسة على المنهج الوصفي، واستخدمت اسنبانة

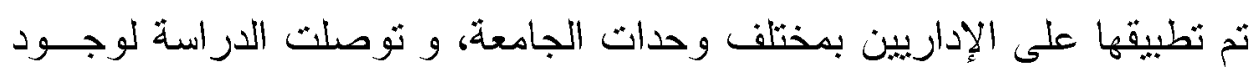
علاقة ارثباطية بين كل محور من محاور إدارة الجودة الثــاملة (دعـــ الإدارة العليا و التحسين المستمر، و الثركيز على الزبون، التخطبط الإستر اتيجي لإدارة

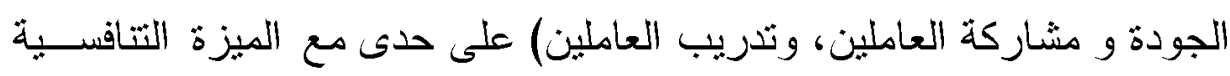

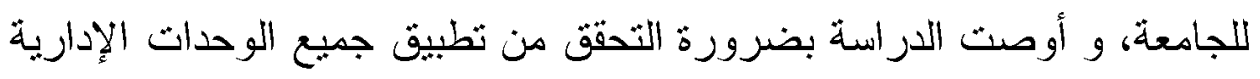

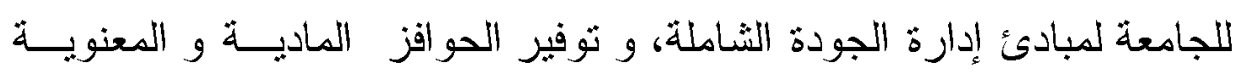

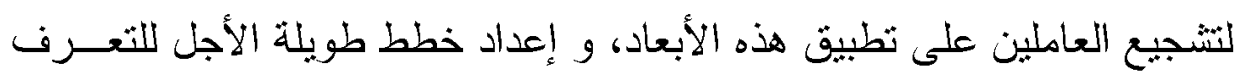
على احنباجات الطلاب لنطوير الخدمات المُقدمة لهم.

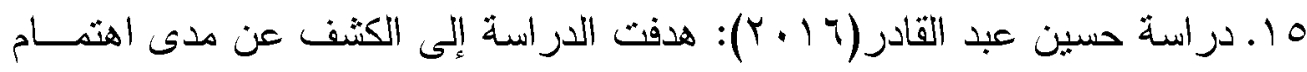
إدارة جامعة الاستقلال الفلسطينية بر أس المال الفكري لنعزيز الميزة النتافسية لها، هله

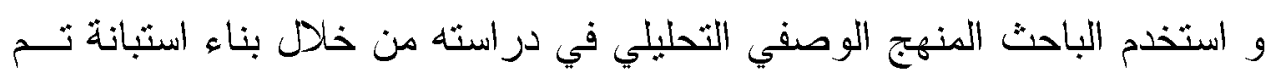

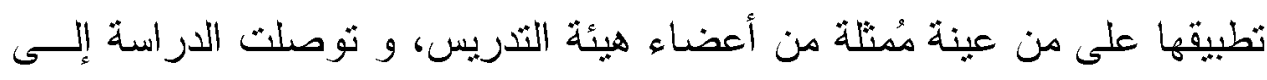
عدة نثائج أهمها: أن الجامعة تشتثطب الأكاديمين المتميزين ذوبي الرتب العلميــة

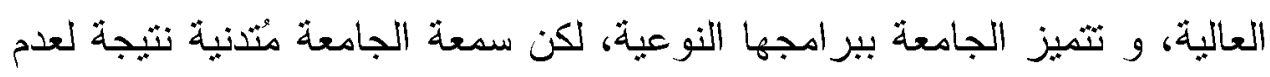

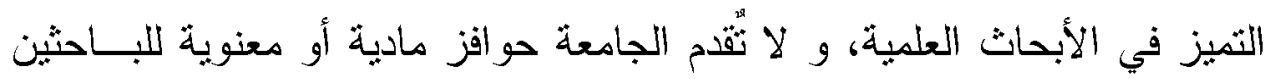

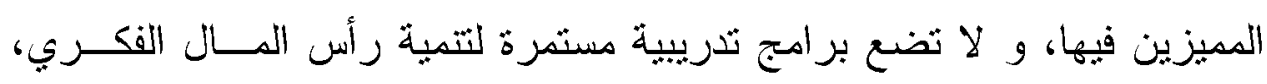


وأثـارت نتائج الدراسة عدم وجود علاقة ذات دلالة إحصائية بين اهتمـام إدارة الجامعات برأس المال الفكري و ثعزيز الميزة التتاقسية لديها تُعزي إلى منغيرات الدر اسة.

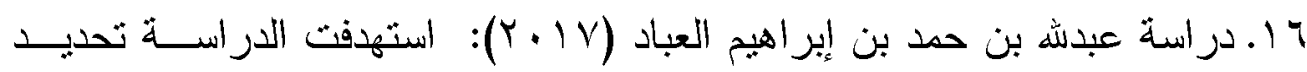
متطلبات رفع القدرة التتافسية لجامعة الملك سعود في ضوء معايير التصــنيفات

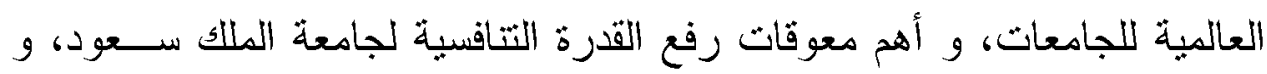
صياغة نموذج مقترح لرفع القدرة التنافسية لجامعة الملك سعود في ضوء

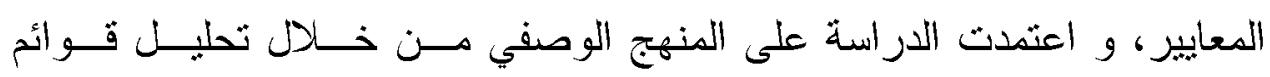

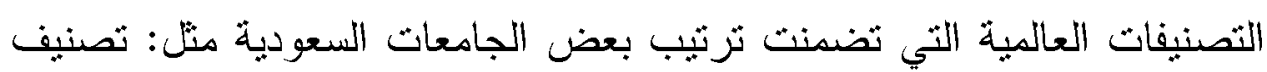
ويبماتركس، و التصنيف البحثي للجاهعات Sclmago، و تصنيف شنغهاي للعام

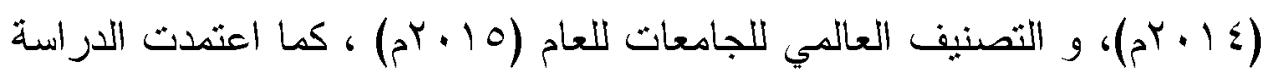
على تحليل خبرات بعض النماذج الجامعية الرائدة على مستوى الثصنيف العالمي للجامعات، مثل جامعة هارفارد التي تحتل مُقدمة التصنيف، وفي النهاية توصلث

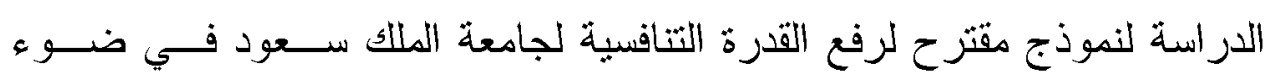

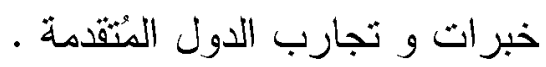

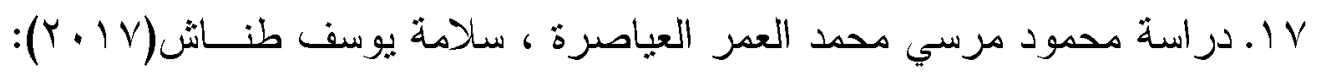
هدفت الدراسة التعرف إلى واقع الميزة التتافسية في الجامعات الأردنية الحكومية

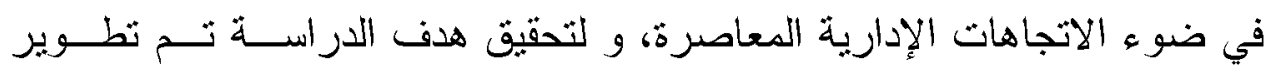

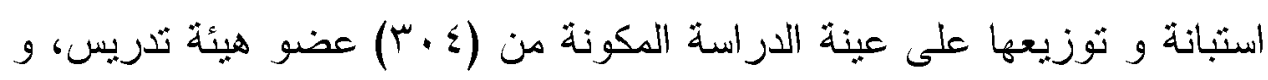
اعتمدت الدراسة على المنهج الوصفي المسحي في جمع بياناتها، و أظهرت نثائج الدراسة أن درجة ثقدير واقع الميزة التتافسية في الجامعات الأردنية الحكومية من

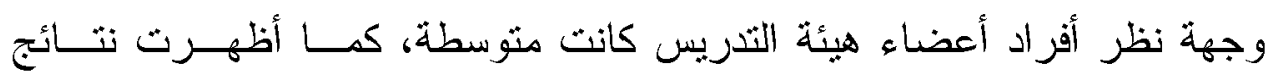
الدراسة عدم وجود فروق ذات دلالة إحصائية تعزي لأثز متغير طبيعة العمل في هي جميع المجالات و في الواقع ككل، و أوصت الدراسة بضـــرورة ثبنــي مفــاهيم

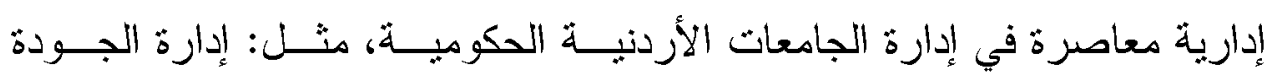


الثاملة، و إدارة المعرفة، و هندسة إدارة العمليات، و الثي تئدي إلى رفع كثاءة

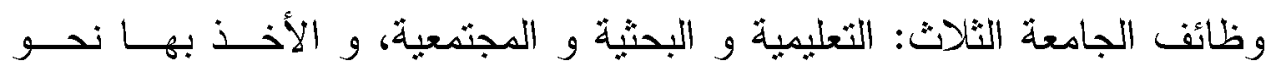
التنافسية .

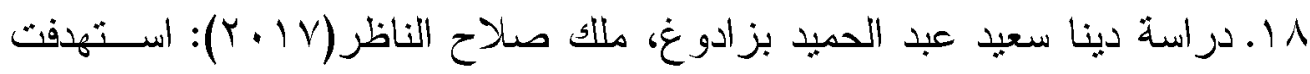

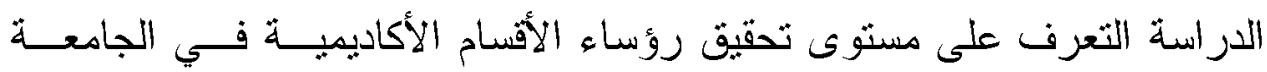

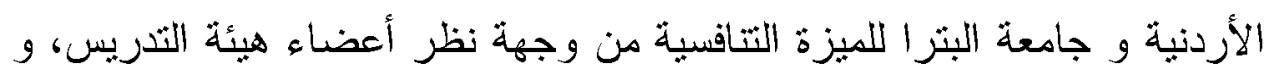
تكونت عينة الار اسة من (Y9V) عضو هيئة تــدريس، و اســتخدت الباحثـــان المنهج الوصفي، و استخدمت الاستبانة أداة لجمع البيانات، و أظهرت الدراســـة فئه النتائج الآتية: أن مستوى تحقيق الميزة النتافسية في الجامعة الأردنية و جامعسة

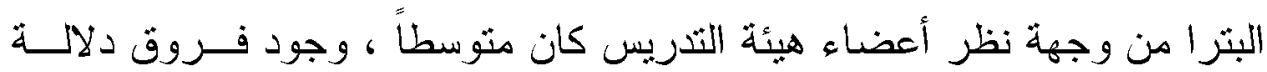

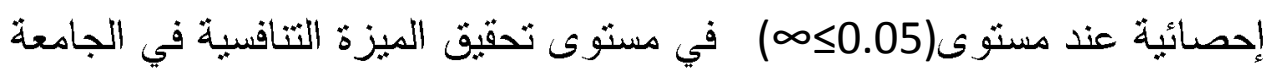

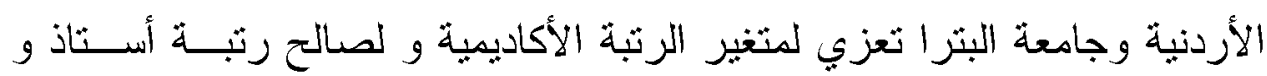

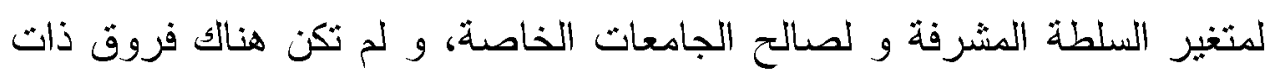

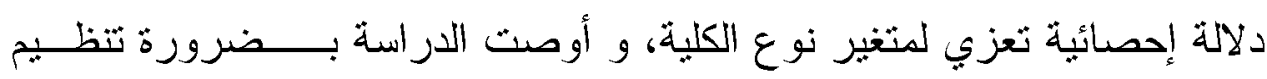
دورات تدريبية لرؤساء الأقسام في مجال الميزة التنافسية الجامعية .

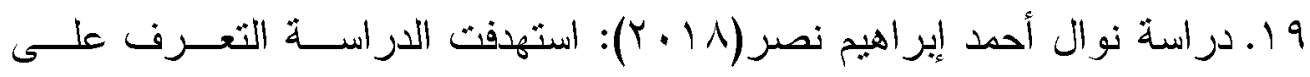
منطلبات تفعيل إدارة المعرفة بالجامعات المصرية في تتمية القدرة على الإبداع و

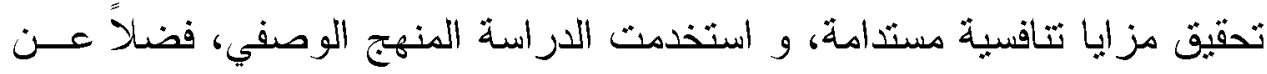
استخدام أسلوب المقابلة الثخصية المحدودة مع القيادات الإدارية بجامعسة عـين شمس ، و اقترحت الدر اسة ضرورة ثبني الجامعة آلبات نُهم في تدفق المعلومات

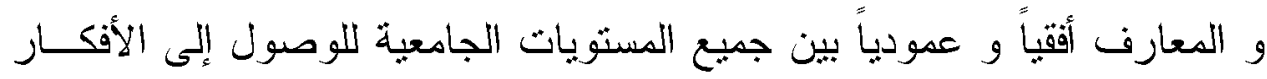

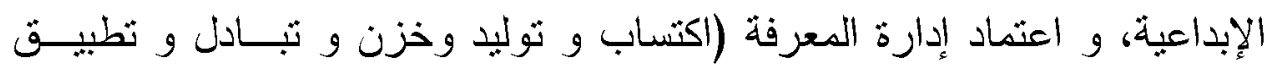
المعرفة) من قبل القبادات الجامعية بما بُحقق مزايا تتافسية للجامعة.

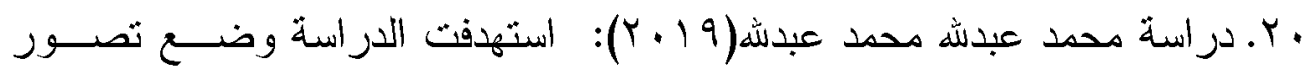
مقترح لتحقيق الميزة التنافسية لمؤسسات التعليم العالي بتطبيق مدخل سلسلة القيمة 
في ضوء بعض النماذج العالمبة، و اعثدث الدراسة على المــنهج الوصــفي، و

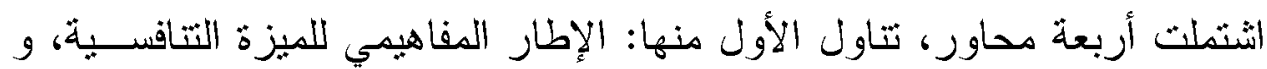

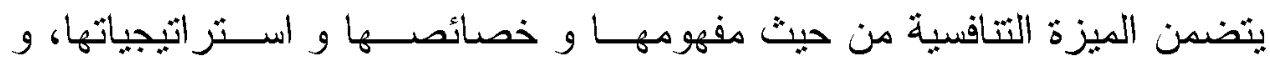

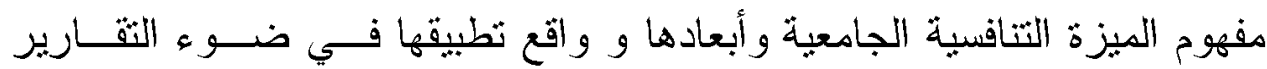

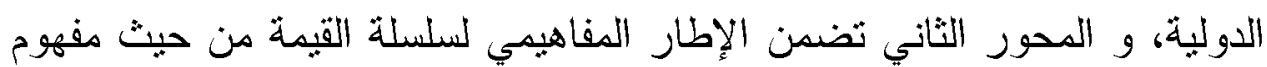

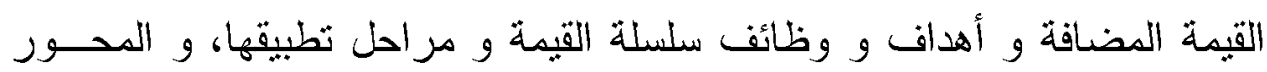

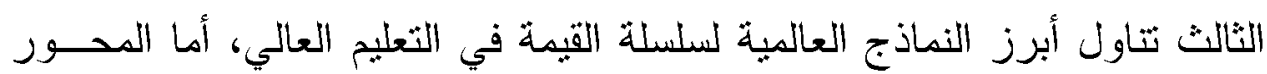
الر ابع فتضمن تصوراً مقترحاً لتحقيق الميزة التتافسية لمؤسسات التعليم العالي في ضوء مدخل سلسلة القيمة . التعقيب على الدر اسات السابقة: أولاً: من حيث موضوع علئ البحث و أهدافه:

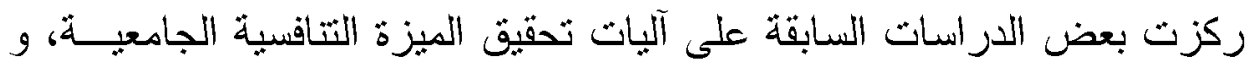

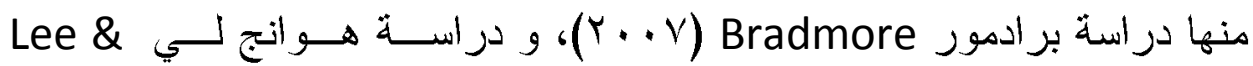
Huang

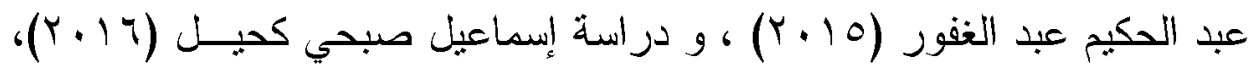

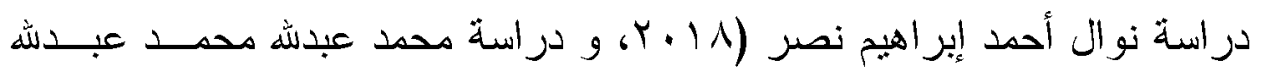
$\cdot(r .19)$

ركزت بعض الدراسات على التعرث على واقع تو افر أبعاد الميـزة التتافسـبـة

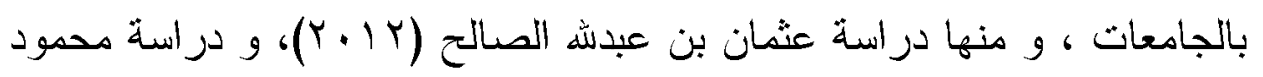

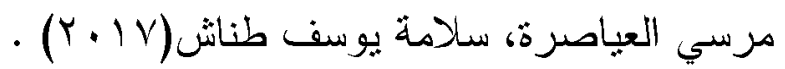

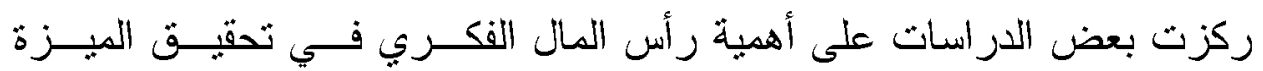

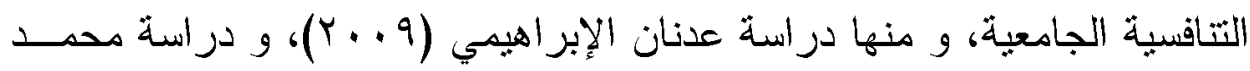

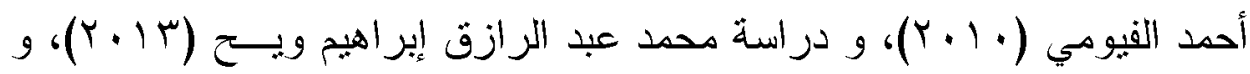

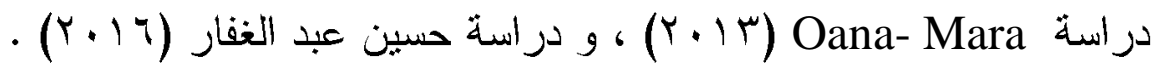


ركزت بعض الدر اسات على منطلبات استدامة الميزة التنافسية بالجامعـات ، و

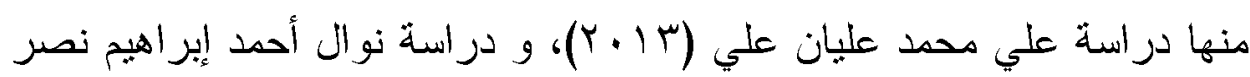
$\cdot(r \cdot 1 \Lambda)$

ركزت بعض الدر اسات على منطلبات تدعيم الميزة التتافسية في ضوء منطلبات اقتصاد المعرفة ، و منها دراســة Soegoto, Eddy Soeryanto (2009)، و و دراسة منال رفعت مصطفي غنايم (10 (Y) و).

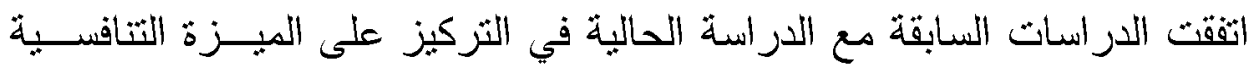

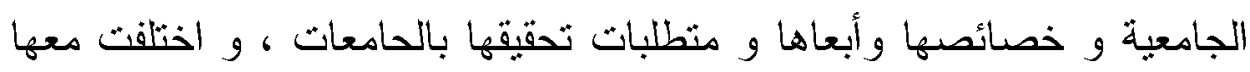
في ثقديم تصور مقترح لمنطلبات نطوير الميزة التنافسية في ضوء الاتجاهــات العالمية المعاصرة ، و استفادث الدراسة الحالية من الدراسات السابقة في إثــراء الإطار النظري للبحث الحالي و إعداد أدواته و تفسير نتائج الدراسة المبدانية .

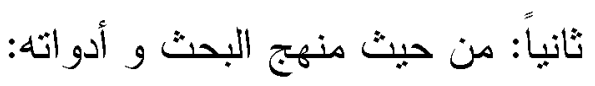

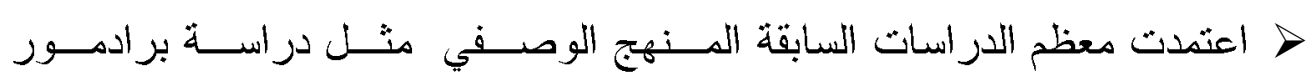
Soegoto, Eddy Soeryanto Bradmore

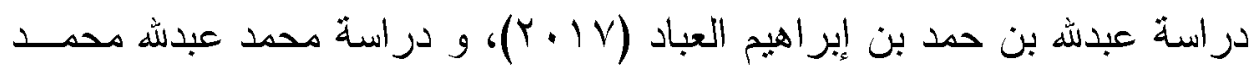

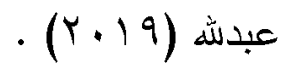

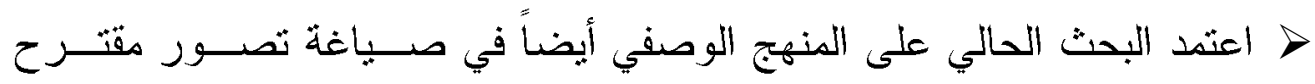

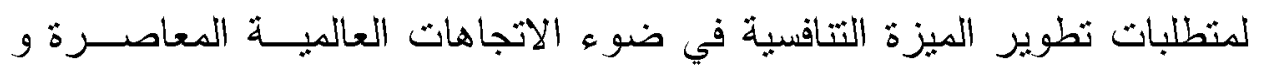
المداخل الأكاديمية و الإدارية و الخبرات و التجارب العالمية .

\section{ثالثاً: من حيث نتائج البحث}

توصلت بعض الدراسات إلى أن درجة نو افر أبعاد الميزة التتافية بالجامعات قد

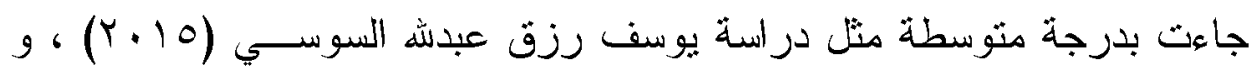

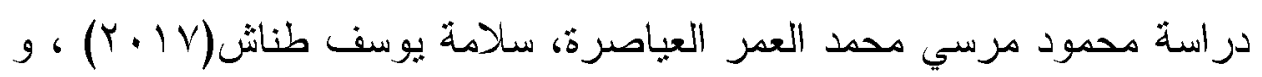

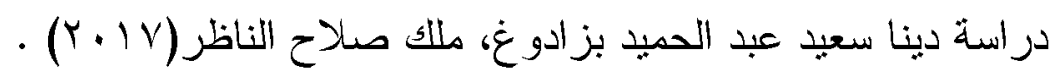


أثنارت بعض الدراسات السابقة إلى ضرورة تطوير البنية التحنية للجامعات ، و تطوير مرافقها لاجتذاب أفضل الأسـاتذة و الطلاب ، و تحقيق مزايــا نتافسـية مستديمة .

> توصلت بعض الدراسات السابقة إلى منطلبات رفع القرة التتافسـية للجامعسة

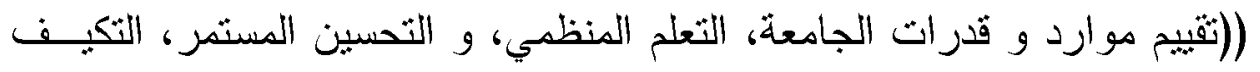

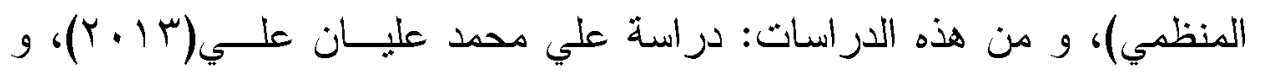

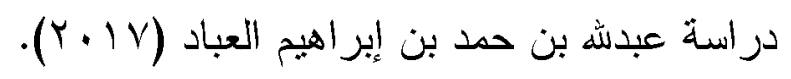

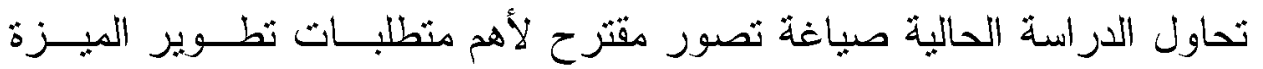
التتافسية الجامعية في ضوء الاتجاهات العالمبة المعاصرة و المداخل الأكاديمية

$$
\text { أهمية البحث: الإدارية و الخبرات و التجارب العالمية . }
$$

تتبع أهمبة البحث الحالي من خلال العناصر الثالية:

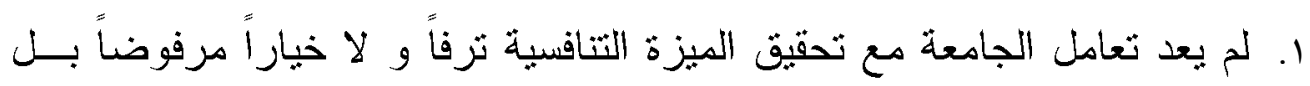

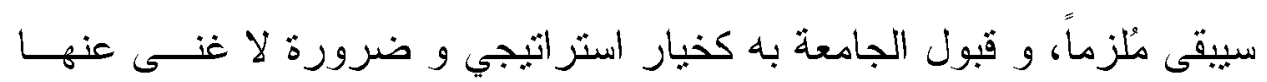
ستكون بدابة المسار الصحيح جودة وإبداعاً .

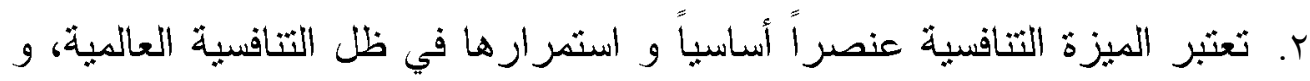
تعزيز المبزة التتافسية للجامعات يصب في صالح أطر اف عديدة هي الطلاب و أصحاب الأعمال و الاقتصاد القومي ككل .

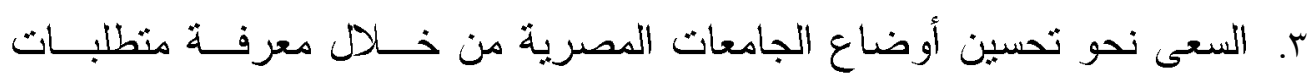
استدامة المزايا النتافسية.

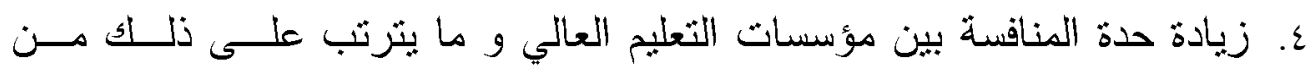

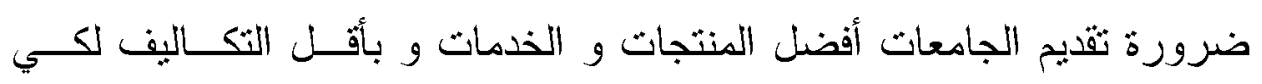
تسنطيع أن نُبت نفسها في هذا السوق التنافسي. 
0. محاولة إفادة القيادات الأكاديمية و أعضاء هبئة التدريس في جامعة أسوان بنتائج

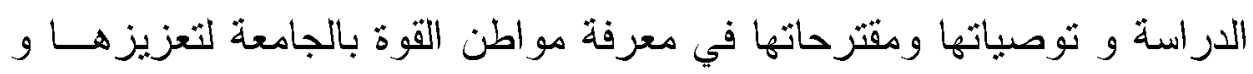
مواطن الضعف لتحسينها .

أهداث البحث: يستهدف البحث الحالي تحقيق الأهداف الثالية:

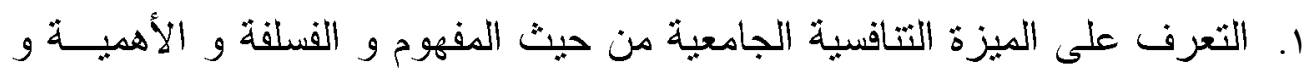

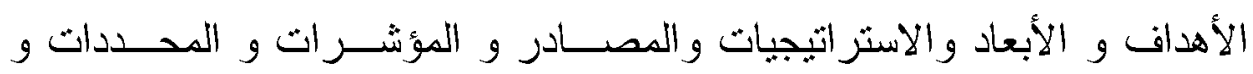

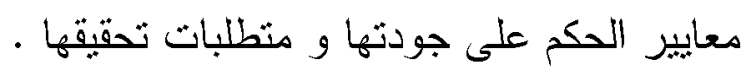
r. التعرف على أهم الاتجاهات العالمية المعاصرة و المداخل الأكاديمية في مجــال تخليق المبزة النتافسية .

r. استعر اض بعض التجارب و الخبرات العالمبة الرائدة في مجال تخليــق المبــزة

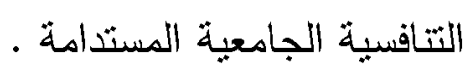

ع. التعرف على الفرص و الثهديدات التي تطرحها ثلك التوجهات العالمية على واقع تُحقق الميزة التتافسية .

0. التعرف على واقع امتلاك جامعة أسوان لأبعاد و استر اتيجيات الميزة التتافسـية ونقاط القوة و الضعف لديها.

7. صياغة مجموعة من المثطلبات الثربوية لتحقيق الميزة التتاقسية لجامعة أســوان في ضوء نتائج الدراسنتين النظرية و المبدانية وفق نتائج تحليل الييئة الاخلية و ولئية

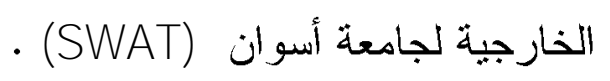
منهج البحث و أدواته:

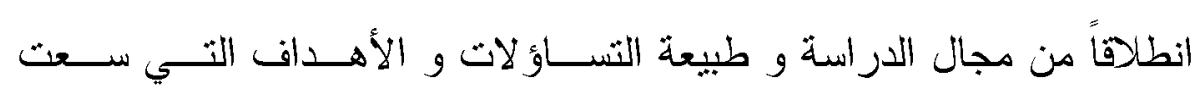
لتحقيقها، استخدم الباحث المنهج الوصفي الذي يلائم مجال الدراسة، "و هـــو يهــتم

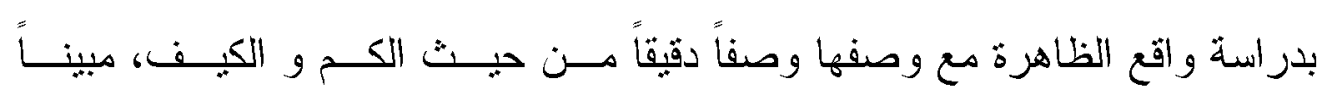
خصائصها و أبعادها و درجة ارثباطها مع الظواهز الأخرى، بعـــ جمـع بيانــات تفصبلية عنها، و يتعدى ذلك إلى التعرف على العلاقات بين المتغيرات الثي نُؤثر في 
متطلبات تطوير الميزة التتافسية لجامعة أسوان في ضوء الاتجاهات العالمية المعاصرة

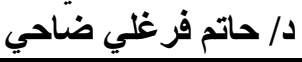

الظاهرة و التنبؤ بحدوثها و نتائجها، و الاستثلال عليها في مجثمع الدراسة" (جـابر

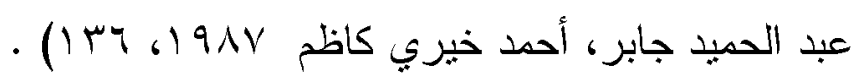
و لتحقيق أهداف البحث ثام الباحث بتصميم استبانة لقيــاس مــدى امــتلاك جامعة أسوان لأبعاد الميزة التتافسية الجامعية و أساليب تحقيقها، و تضمنت الاسنبانة ستة أبعاد هي: الجودة العالية، و الإبداع المتفوق، والاســتجابة المتفوقــة لحاجــات العملاء و المستفيدين، و المرونة، و التكلفة و ثرشبد النفقات، و التميز و التفوق على ، ونى المنافسين، و ثم نطبيقها على عينة مُمثلة من القيادات الجامعيــة و أعضـــاء هيئسة

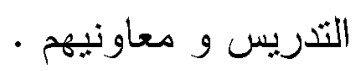
حدود البحث: تثمثل حدود البحث فيما يلي: ا.حدود الموضوع: يقتصر البحث الحالي على دراســة إمكانبــة تطــوير الميـزة

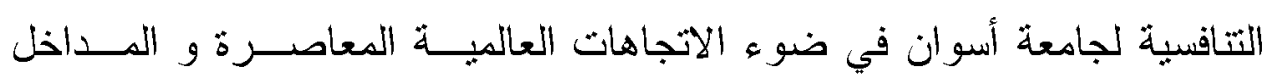
الأكاديمية و الخبرات الدولية في مجال تخليق المبزة النتافية . Y.الحدود المكانية: تم تطبيق الدراسة المبدانية على بعض الكليات العملية و النظرية بجامعة أسوان بكليات (الثربية، و الآداب، و العلوم، و الهندســة، و الزراعــة و الموارد الطبيعية، و التجارة، و الألسن، و الخدمة الاجنماعية، و التربية النوعية، و التربية الرياضية، و كلية تكنولوجيا المصايد و الأسمالك ) . r.الحدود البشرية: نم تطبيق استبانة أبعاد المبزة التتافسية في ضــوء الاتجاهــات العالمبة المعاصرة على عينة ممثلة من القيادات الجامعية و أعضاء هيئة التدريس و معاونيهم ـ. الحدود الزمانية: تم تطبيق الدراسة الميدانية في الفصل الدراسي الأول من العـام

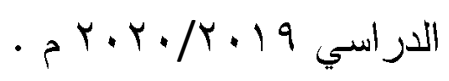


مصطلحات البحث:

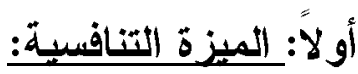

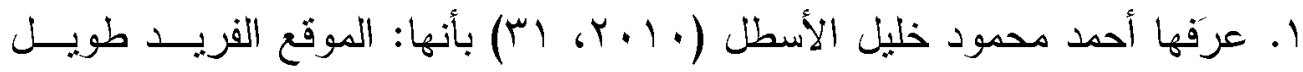

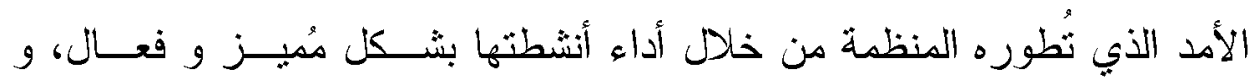
استغلال نقاط قوتها باتجاه تقديم منافع فائقة لزبائنها .

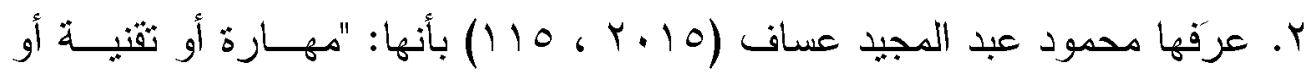
مورد منميز يُتيح للمنظمة أداء أعمالها بالثكل الذي يصعب على على منافسيها ثقليده، و ذلك من خلال ممارسة الأنشطة بأقل ثكلفة". ب. يرى الباحث أن الميزة التتافسية هي عنصر تفوق للمنظمة يتم تحقبقه عند اتباع

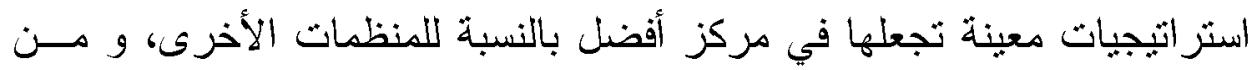

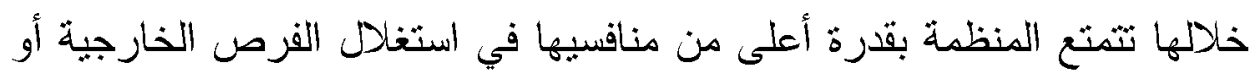
الحد من ثأثير التهديدات الخارجية بشكل يصعب على منافسيها ثقليده . ثانياً: المبزة التنافسبة الجامعبية

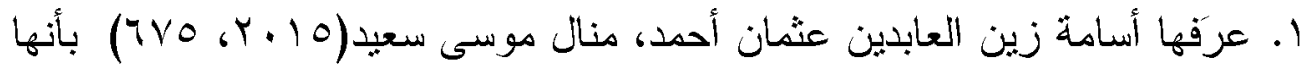
: "قدرة الجامعة على المحافظة على استمر ارية تحسين جودنها التعليمبــة عبــر الزمن أو زيادة الطلب علبها، مما يُؤدي إلى ارتفاع قيم مؤشرات التنافسية لهــــهـ الجامعات، و بالتالي حصولها على مر اكز مثقدمة في الترثيب العالمي للجامعات.

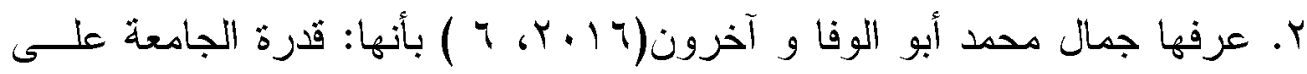

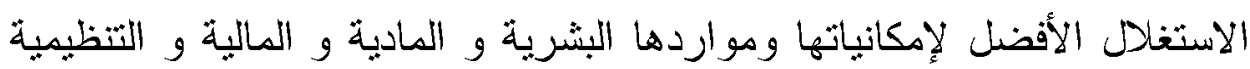

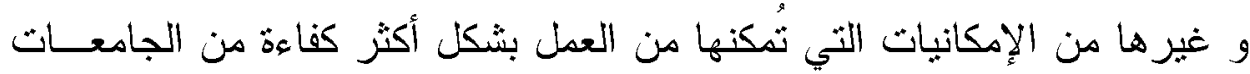

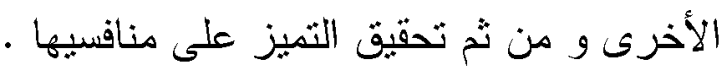

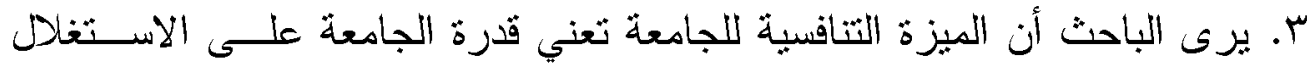

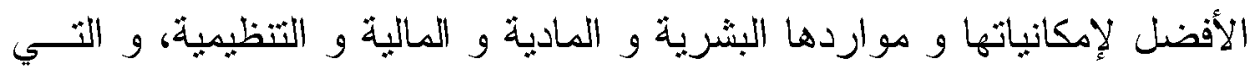

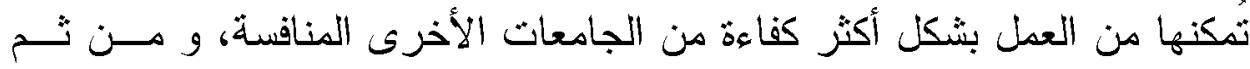

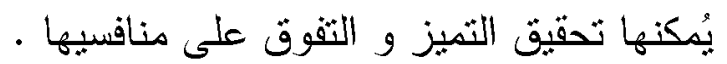


ا. للإجابة عن السؤال الأول: (ما الأسس الفلسفية و المفاهيمية للمبـزة التنافسـية الجامعية؟) يقوم الباحث بإجر اء دراسة نظرية حول الميزة التتافسية الجامعية من

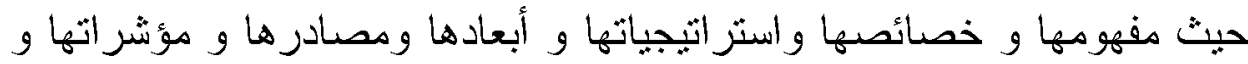
منطلبات تحقيقها، و ذلك من خلال الإطلاع على الأدبيات التربوية و الإدارية . r. للإجابة عن السؤال الثاني: (ما الاتجاهات العالمية المعاصرة في مجال تخليـق الإنق

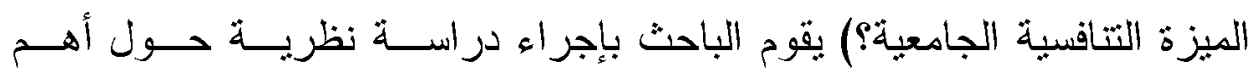

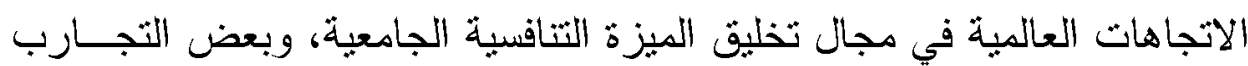

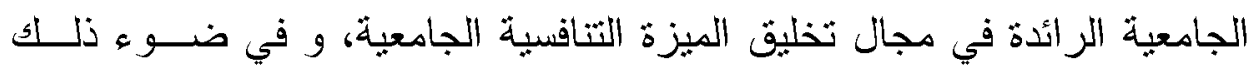

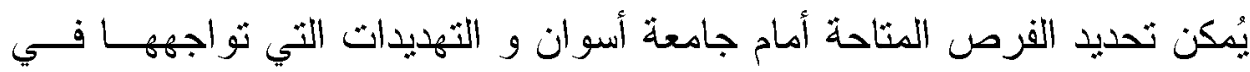
• السياق العالمي

r. للإجابة عن السؤال الرابع: (ما مدى ثوافر أبعاد الميزة التتافسية بجامعة أسوان من وجهة نظر هيئة التدريس و القبادات؟) يقوم الباحث بإجر اء دراســـة مبدانيــة

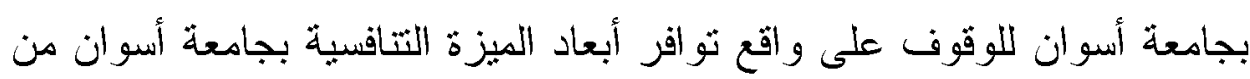

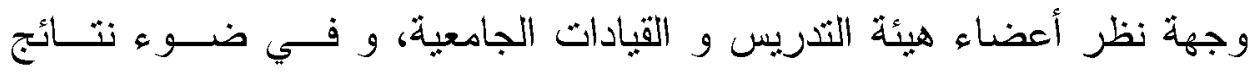

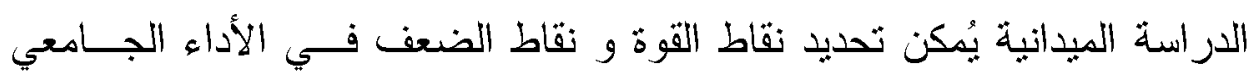

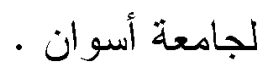
ـ. للإجابة عن السؤال الرابع: (ما متطلبات تطوير الميزة التتافية لجامعة أســـوان في ضوء الاتجاهات العالمبة ؟) يقوم الباحث بمحاولة التوصل لمجموعة مـن

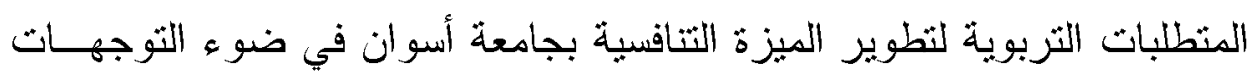
العالمية و المداخل الجامعية الأكاديمية و الإدارية الحديثة و التجارب الدولية. المحور الأول: الأسس الفكرية و الفلسفية للمبزة التنافسية والهية

برز مفهوم الميزة التتافسية في حقل الإدارة في فترة الستينات مــن القــرن

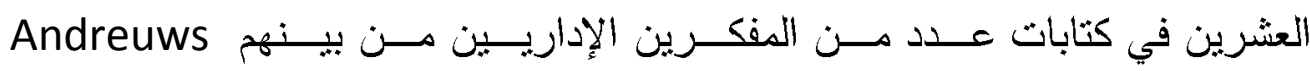


Christensen

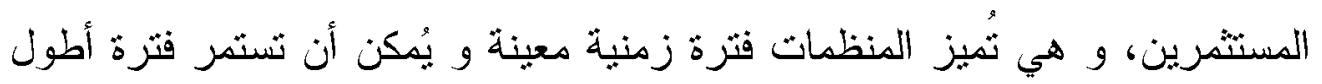

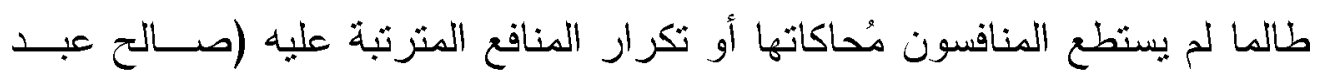

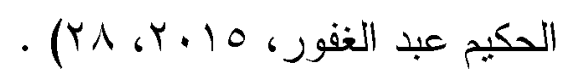

و ارتبط التزكيز على المبزة التنافسية بظهور كتابـات Michael Porter أستاذ الإدارة الإسنر اتيجية بجامعة هارفارد، حيث قدم أول مؤلف له في هذا المجال

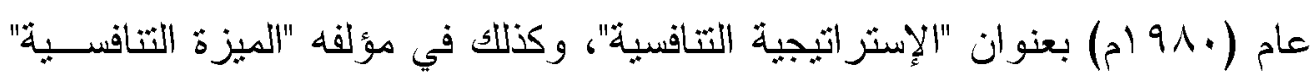

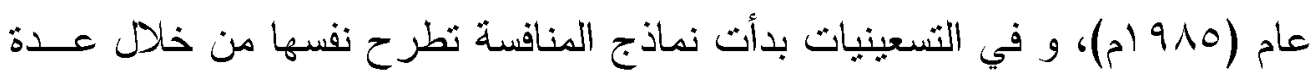
إستراتيجيات منها: نقليل التكلفة، و نحقيق الثميز، و التركيز على العميل، و نجــاح

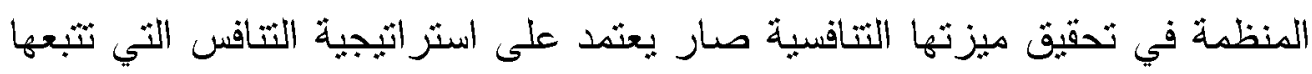

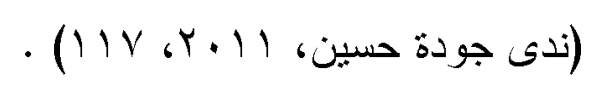

و تتشأ الميزة التتافسية بمجرد نوصل المنظمة إلى اكتثاف طرق جديدة أكثر

فعالية من تلك المستخدمة من قبل المنافسين، و يكون بمقدورها تجسيد هذا الاكتشاف مبدانباً، و تثصف الميزة التنافسية بأنها: نسيبة و لبيت مُطلقة، و نتحقق بالمقارنة، و و

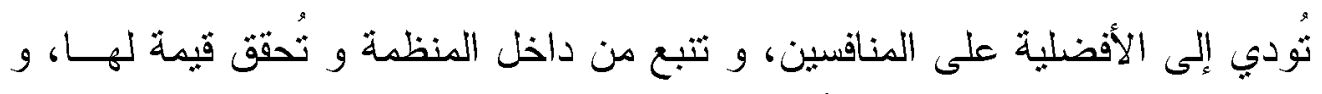

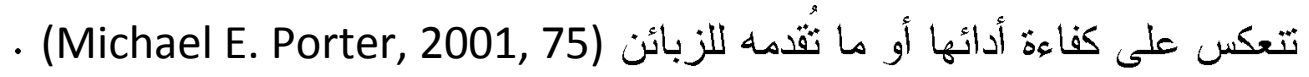

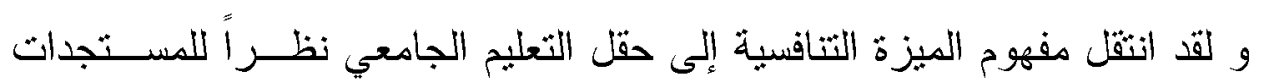

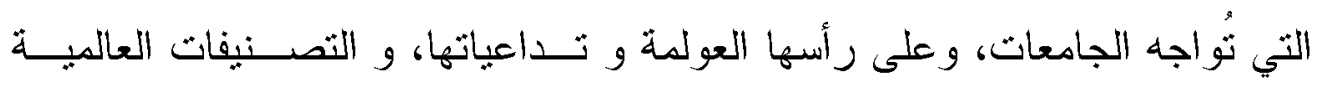

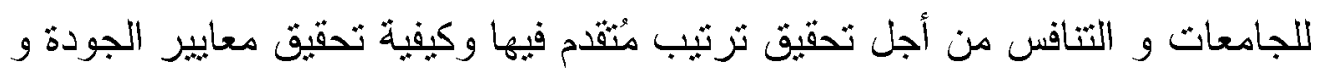
الاعنماد، و هذا يضع الجامعات المصرية في منافسة شديدة على المسنوين المحلى

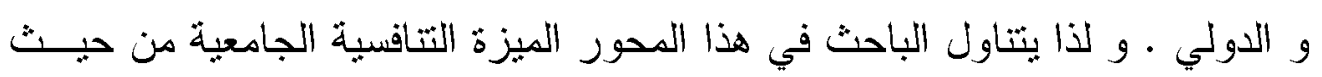

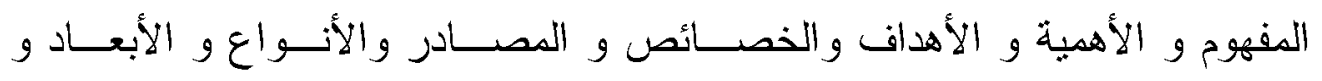

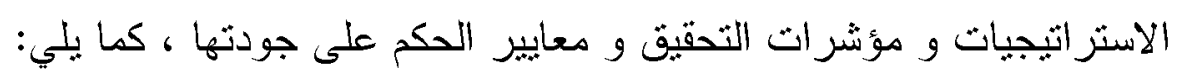




\section{الميزة التنافسية: النثأة و تطور المفهوم :}

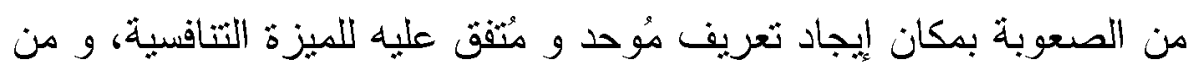

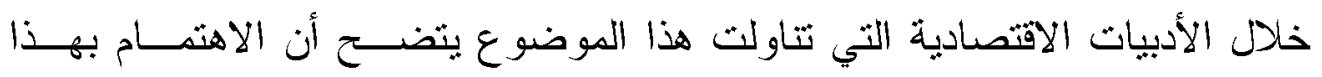
المفهوم قد تز امن مع العجز في الميزان التجاري للولايات المتحدة الأمريكية خــلال

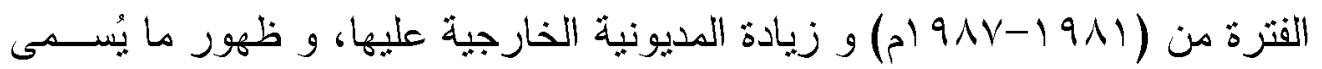

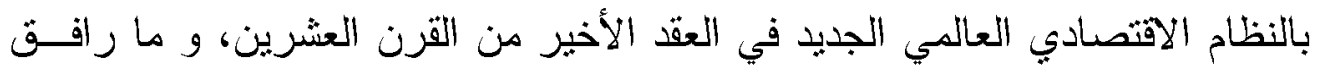

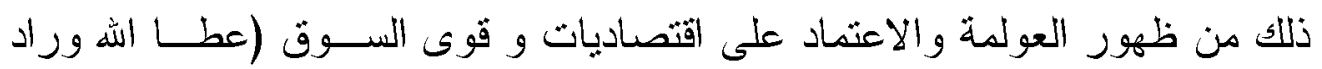

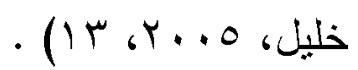

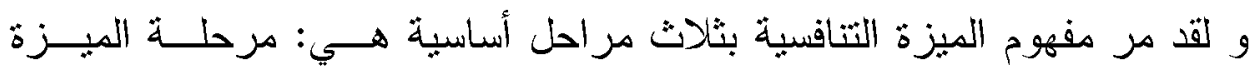

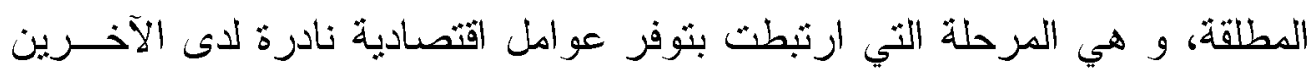

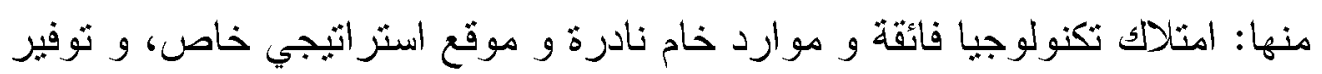

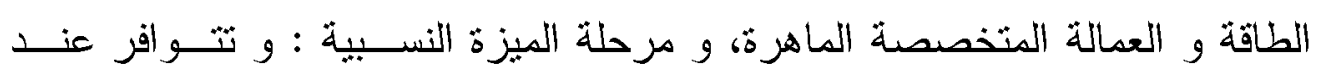

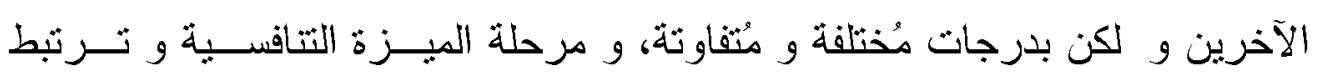

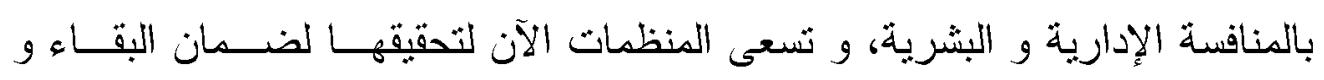

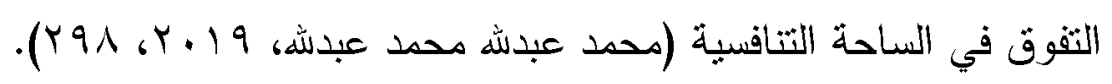
و فيما يلي بتناول الباحث بعض تعريفات المبزة التنافسية:

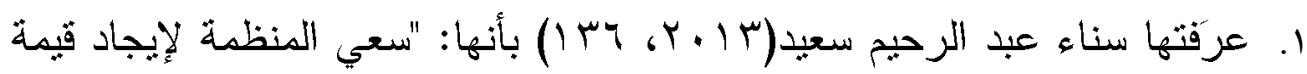

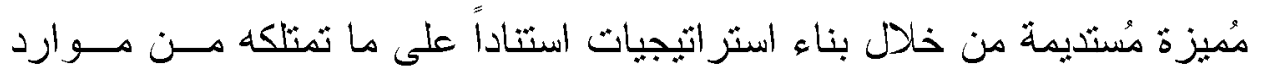
يصعب على المنافسين من تقليدها".

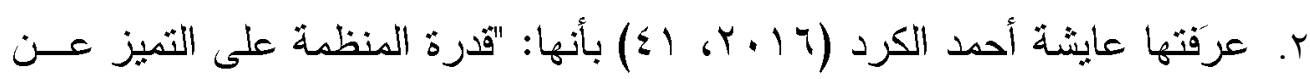
غيرها من خلال تقديم منافع متمبزة، و استغلال أفضل للموارد التي تمنلكهــا و و

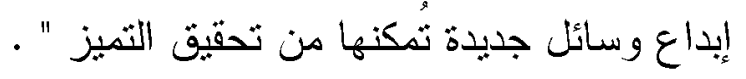

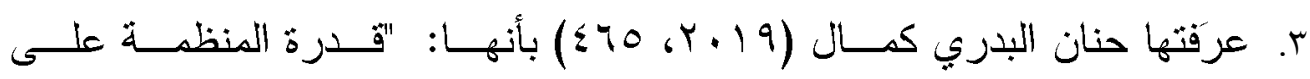
الاستغلال الأفضل لإمكانياتها ومواردها البشرية و المادية و المالية و التنظيمية، 
متطلبات تطوير الميزة التنافسية لجامعة أسوان في ضوء الاتجاهات العالمية المعاصرة

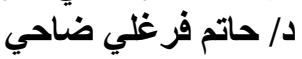

و الثي ثُكنها من العمل بكفاءة عالية و قدرة على تحقيق التفوق على منافسيها،

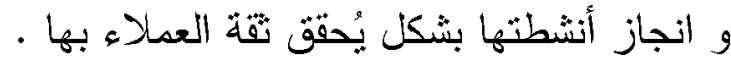

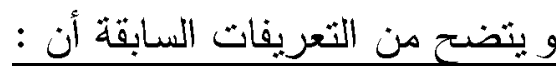

الميزة التتاقيبة تعني قدرة المنظمة على ثقديم قيمة منفوقة للسوق لمدة طويلة من الزمن

الميزة النتافسية تعني قدرة المنظمة على خلق شيء مثفرد و مختلف عن بقيـة • المنافسين الميزة التتافسية هي استغلال المنظمة لنقاط القوة الداخلية لأداء الأنثطة الخاصة ب. بها الميزة التتافسية هي تطبيق تكنولوجيا المعلومات بشكل رائــد لغــرض التقــدم • التناقسي لا نُسهم المبزة التنافسية في تحقيق الفوز للمنظمة على منافسيها و بالتــالي جنـي

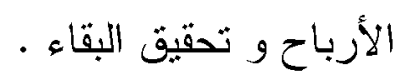
>ا الميزة التتافية تثحقق عندما ثتميز المنظمة بقدرثها على تلبية احتياجات المستفيد بأقل تكلقة ممكنة . و يرى الباحث أن الجامعات يجب أن ثتفرد ببعض المزايا التتافية التي تُؤهلها

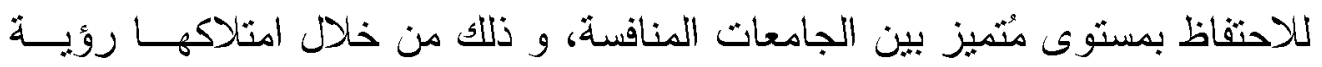
إستر اتيجية واضحة، و قر اءة جيدة للمجتمع المحيط، وتليية لرغبات العملاء، و النمو المستمر للموارد و الإمكانات، و تشعى الجامعات لتثديم منتجات و خدمات جامعيــة

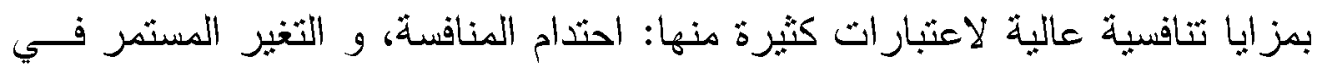

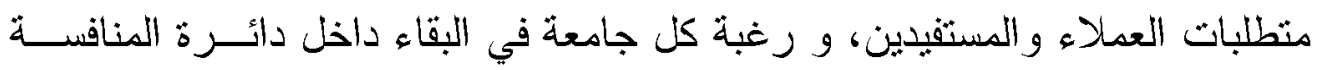

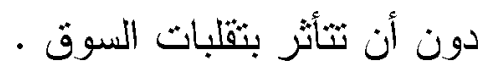


مفهوم الميزة التنافسية الجامعية:

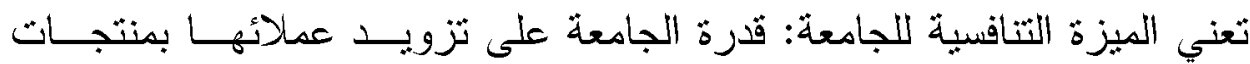

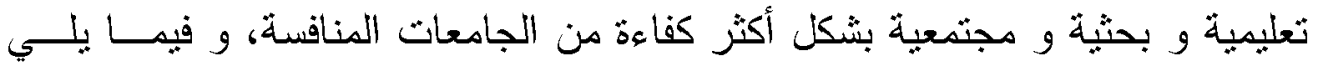
يتتاول الباحث بعض تعريفات المبزة التنافسية للجامعات: ا ـ عرف محمد نصحي سبد أحمد إبر اهيم(9 . . ب) الميزة التتافسية الجامعية بأنهـا: قدرة الجامعة على ثقديم خدمة تعليمية و بحثية عالية الجودة مما بنعكس إيجابـاً

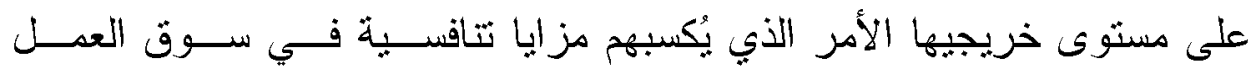
بمستو ياته المختلفة، و في نفس الوقت يعكس ثئة المجتمع فيها و التعاون معهــا.

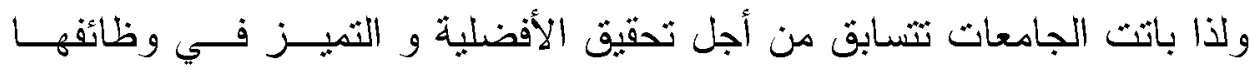
النعليمية و البحثية و المجنمعية .

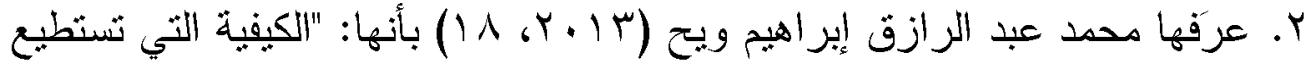

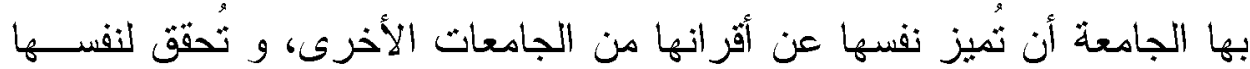

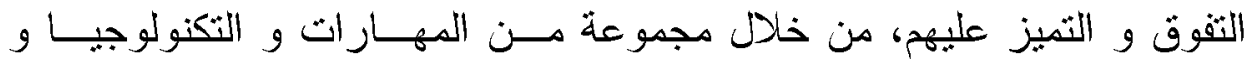
الموارد و القدرات، الثي تسنطيع إدارة الجامعة تتسيقها و اسثنمار ها لخلق قيم و

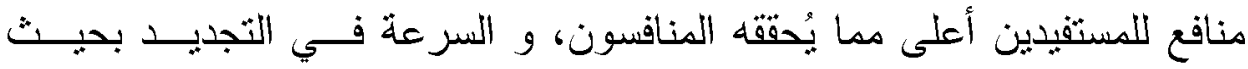
بصعب ثقلبدها .

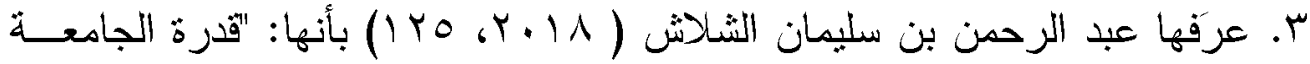
على تحقيق تفوف سوقي على الجامعات المنافسة، و يُمكن القول عن الجامعة أنها بهان حققت ميزة تتافسية عندما تثكن من تحقيق ثيمة مُضافة بفضــل الإســنر اتبجية الثي تثبناها في الوقت الذي بعجز منافسوها عن القيام بذلك .

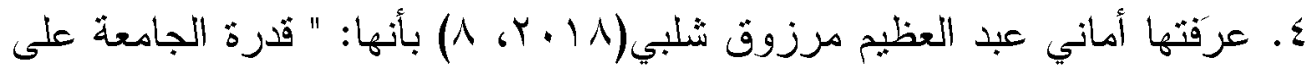

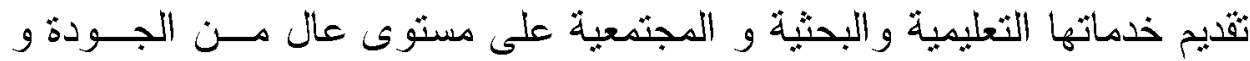
الاتثان و التميز ، هما يُكسب خريجيها و أعضاء هيئة التدريس بها مزابا تتافسية

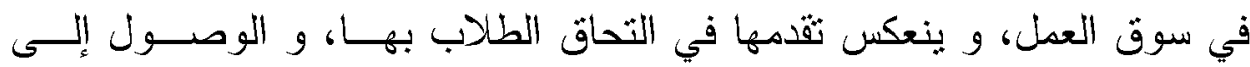
مستوى يُمكنها لأن نكون جامعة من الطراز العالمي . لمئ 


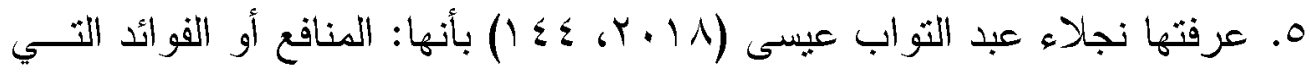
تحصل عليها الجامعة لأبعد مدى مُمكن، و التي لا يُمكن تقليدها أو استتســاخها من قبل الجامعات الأخرى، و هي عملية ديناميكية تتطلق من توجه اســتراتيجي

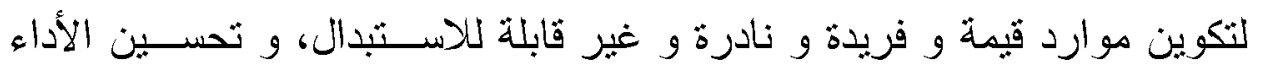

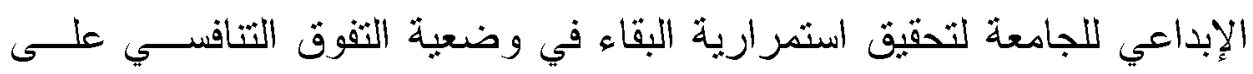
المنافسين الحاليين و المحثلين". من خلال عرض المفاهيم السابقة للميزة التنافسية للجامعات يُمكن استنتاج ما

تمثل الميزة التتافسية للجامعة مؤشر اً لاحتلال الجامعة موقعاً متميزاً بالسوق.

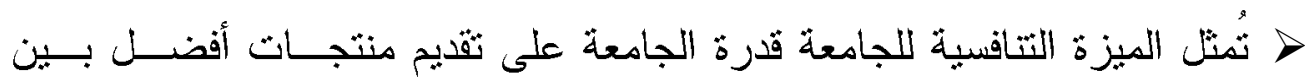

$$
\text { مثيلاتها }
$$

تنطلب الميزة النتافسية للجامعة ضمان الاستدامة فالجامعــات ثُو اجــه تحـدي المحافظة عليها . > تعكس الميزة التتافسبة للجامعة قدرثها على تحقيق قيمــة مضــافة للعمـلاءه و

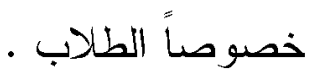
> تُمنل الميزة التتافسية للجامعة مؤشراً لتفردها بثقديم أفضل أدوارها التعليمبــة و

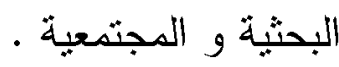
> تثمتع الجامعة ذات المزايا التتافسية بقدرة على تلبية احنياجات العملاء بفعالبـة

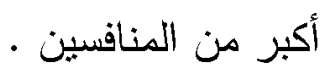
فلسفة الميزة التنافسية الجامعية: تستهدث الميزة التنافسية بصفة عامة البحث المستمر عن الكيفية التي ثُميـز بها المنظمة نفسها عن مُنافسيها، وتُحقق لنفسها التفوق و التميز علبهه، و هذا التفوق يكون في شكل إضـافة قيمة لدى العمبل (المستهلك)، وتأخذ شكل أسعار أقل أو منتج

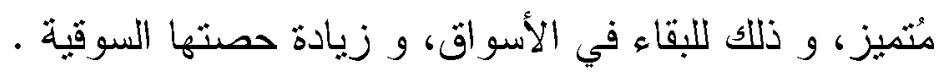


و تعتمد فلسفة الميزة النتافيبة للمنظمــات علـى امتلاكهـــا لمجموعــة

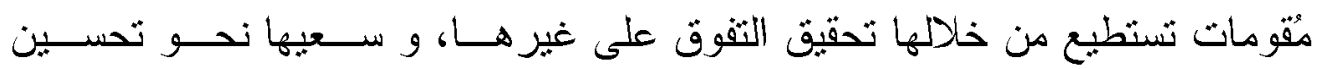

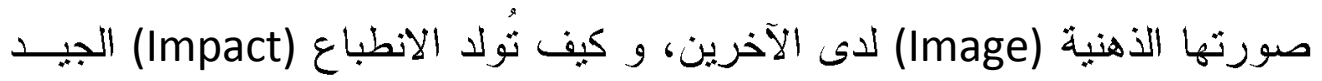

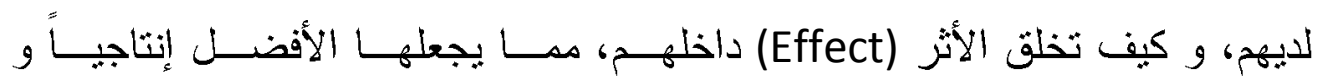

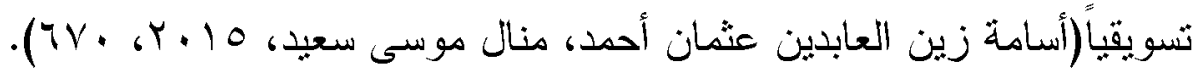

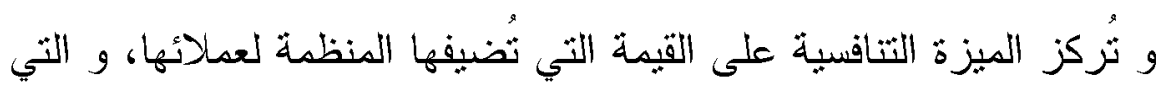

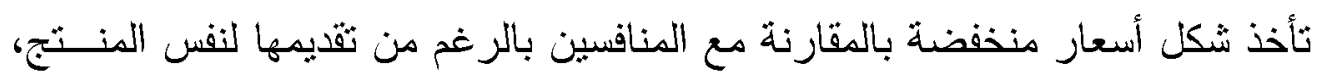

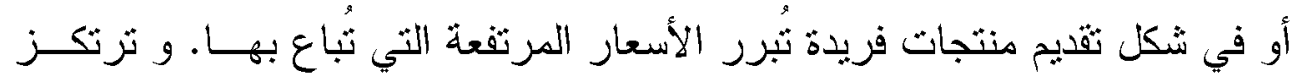

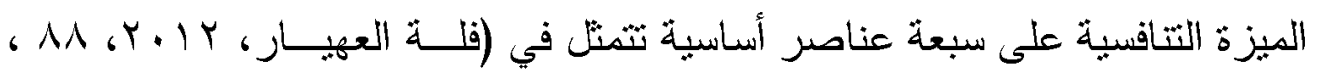
$:(\wedge 9$

1. تعظيم رضا كافة الأطر اف المعنبة من خلال تقديم منتجات و خدمات منمبزة مقارنة بالمنافسين.

r. تحديد الاحتياجات الحالية و المستقبلية للعميل و من ثم تلبيتها بطريقة أفضل مـن

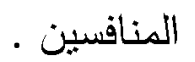

r. القدرة على مفاجئة و إبهار الآخرين من خلال خلق مبزة تتاقسبة جديدة .

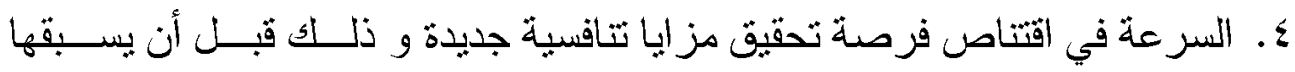
المنافسون. هـ استخدام سلسلة من التكتيكات و الطرق لخلق ميزة تتافسية مُؤقتة مما يُغير في قو اعد

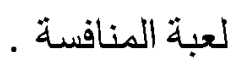
7. الإعلان عن الأفعال الإسنتراتيجية المرغوب اتخاذها مما بسمح بتعطيل ردود أفعال المنافسين V. تنظيم خطو ات متثابعة و متتاسقة للنطور الاستر انيجي مما يسمح بخلـق فـرص

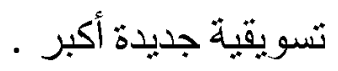

و تستند فلسفة الميزة التتافسية الجامعية على قدرة الجامعة على ثصميم و إنتاج و تسويق منتجات و خدمات جامعية مثفوقة مُقارنة بما ثُقدمــهـ الجامعــات الأخــرى 
المنافسة، و يُمكن بناء مبزة تنافسية للجامعة انطلاقًاً من الموارد الملموسة (المــواد

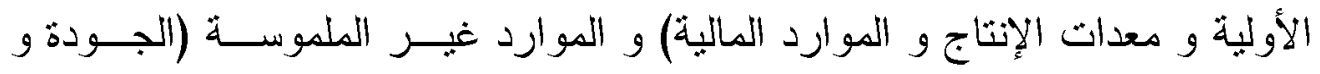

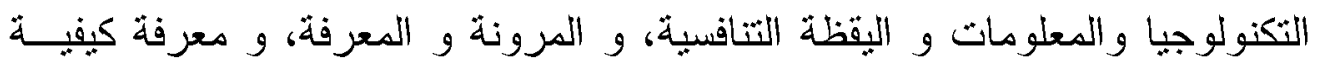

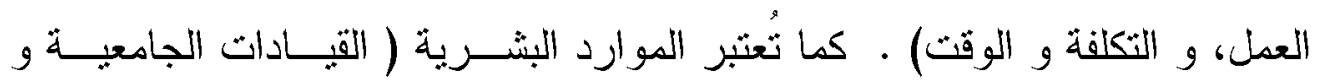

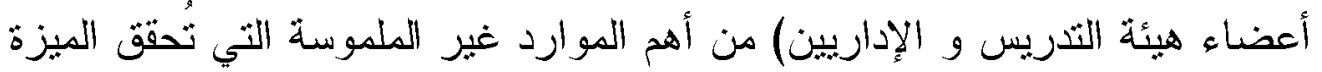

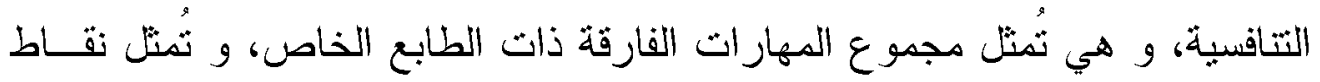
قوة للجامعة تُبح لها تحقيق الريادة لخدماتها بأقل نكلفة مُككنة، و على الجامعة تحديد

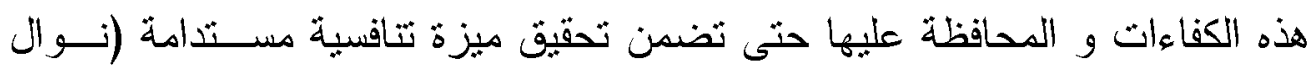

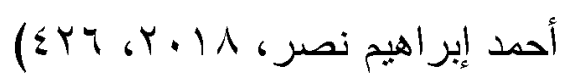
و دن خلال تخليق مزايا تتافية جديدة للجامعات يُكن تحقيق مزيد من المكاسب

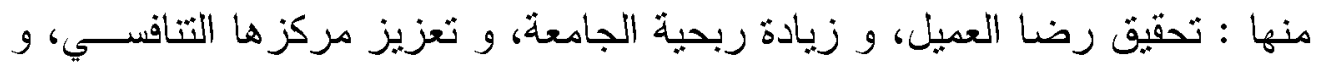

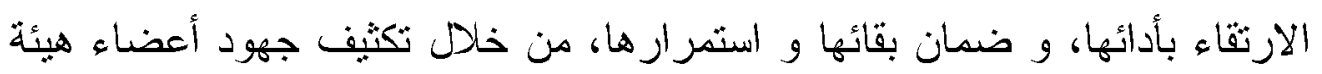
التذريس في البحث و التطوير، و استخدام التقنيات الحديثة في تحسين جودة الخدمات الجامعية، و تعظيم القيمة المضافة من وجهة نظر العملاء و المستفيدين، و بناء ميزة

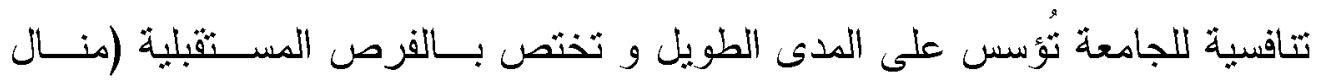

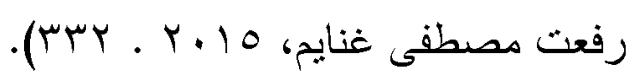

و يرى الباحث أن الميزة التنافسية الجامعية بُمكن أن ثتحقق من خلال : الـــحكم

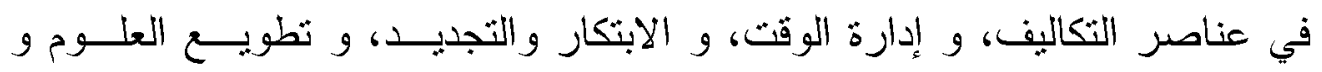

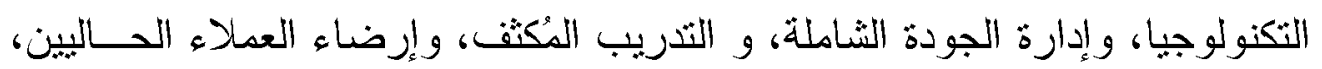
و البحث عن عملاء جُدد، و الترويج و الإعلان، و التحسينات المســتمرة، و تثــيم

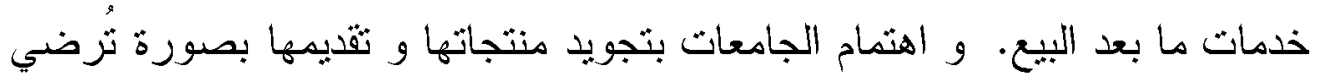

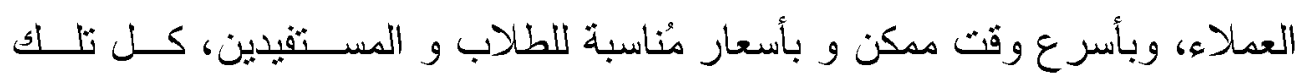
الأدوات تُشهم في تحقيق الميزة التتافسية للجامعة. 


\section{مبررات التجديد في المبزة التناقسية الجامعية:}

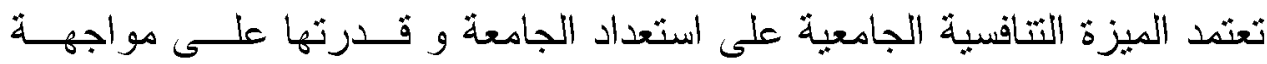
المنافسة الفعلية و المحتملة من جامعاث أخرى منافسة، و تزتبط بالوضعية السـائدة

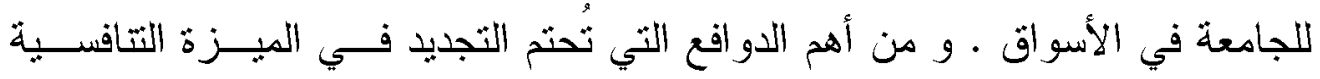

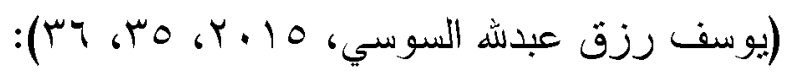
ا. ظهور تكنولوجيات جديدة وفرت فرص جديدة أهمها: ثصميم المنتج أو طــرق النسويق أو الإنتاج أو التسليم.

Y. ظهور حاجات جديدة للمستهلك تثطلب تعديل الميزة التتافسية الحالبــة أو نتميــة ميزة تتافسية جديدة .

ب. ظهور قطاعات سوقية جديدة من المستهلكين مما يُسهم في خلق فـرص جديــدة لتطوير مبزات تثافسية . لته

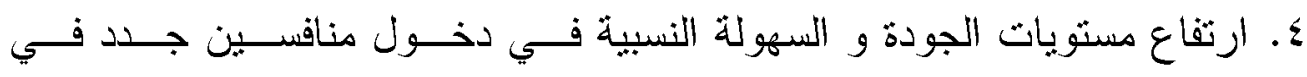

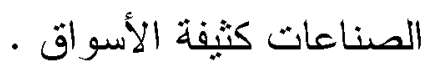

ه. سهولة الاتصالات و نبادل المعلومات بين المنظمات و بــين فــروع المنظمـة

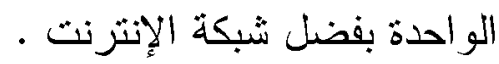
7. تغير تكاليف المُحخلات ( البد العاملة و المواد الأولية و وسائل النقل و الطاقة و

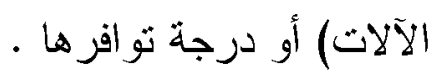

و يُككن تفسير الاهتمام المتزايد بالتتافية في التعليم العالي بغلبة الاتجاه المهني على الاتجاه العلمي في طبيعة التعليم العالي، و كذلك بروز مفهوم السوق و آلياته و بله

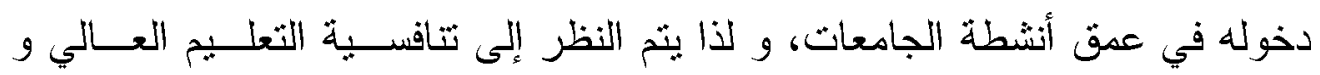
مؤسساته على مسنويين هـا (John V. Lombardi, , 2011, 3): ا. نتافسية قطاع التعليم العالي : و تُشير إلى كافة مؤسسات التعليم العالي التعليمية و التدريبية و البحثية والتوظيفية، و هناك اعنقاد بأن الازدهار الاقتصادي بعتهد

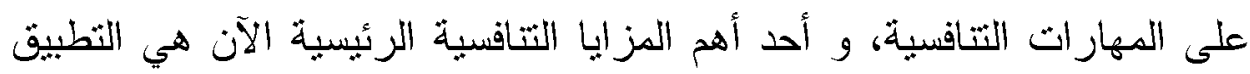

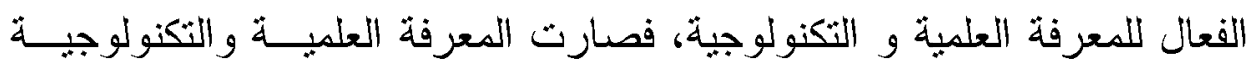


ثُثنلا معاً أساس المنافسة الكونية، حبث بثميز من بكتثف المعرفة الجديدة أولاً، و لذا يُركز تثرير تنافسبة قطاع التعليم العالي في اسكثلندا على القول بأن نجاح

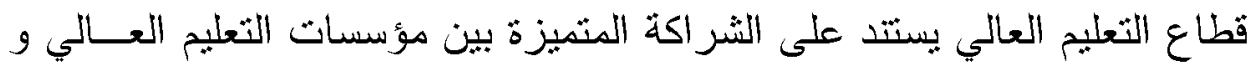

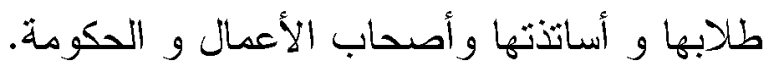

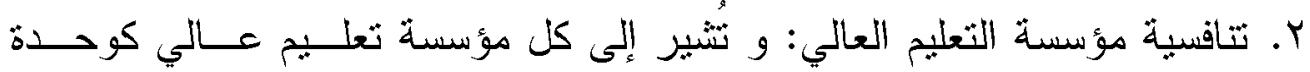

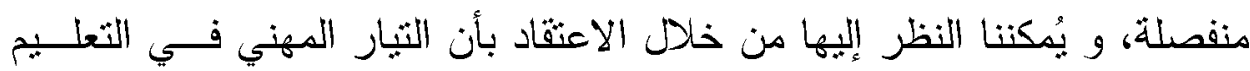
العالي و قوى العولمة جعلا الجامعة متجهة نحو السوق.

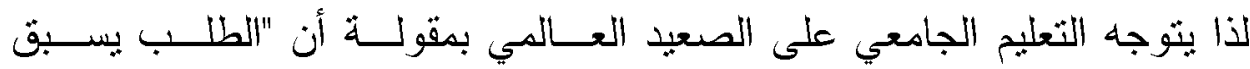
العرض"، و هذا الأمر جعل مُخططي التعليم العالي يربطون بين عمليـات الإعـــاد

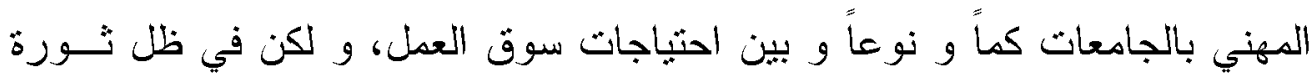

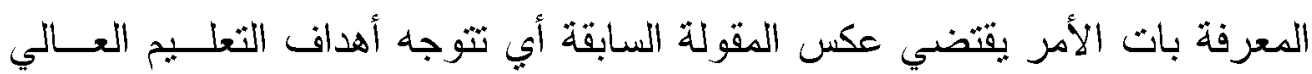
انطلاقاً من أن "العرض بخلق الطلب"، و هذا يفرض علــى الجامعــات أن نكـــون

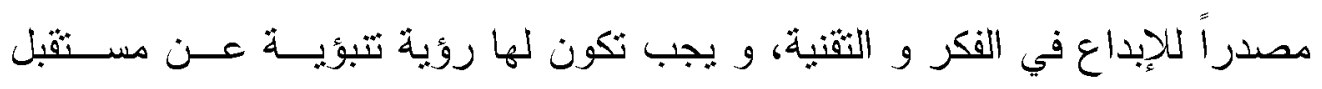

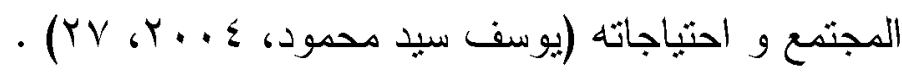
أهمية الميزة التنافسية الجامعية:

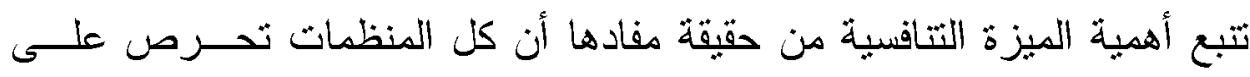
نطويز أدائها لتحقيق الأداء المثفوق، و يتفاوت مسنوى نجاح المنظمة في إحراز هذا التطور حسب كفاءتها في إدارتها الإستر اتيجية، لذا أصبحت مُهارسة للمبزة التتافسية ضرورة حتمية إن أرادث المنظمة زيادة قدرثها الإنتاجية.

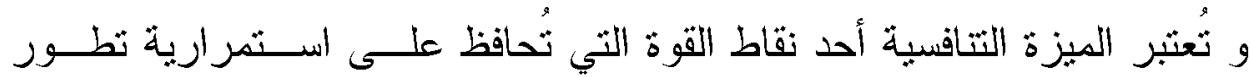

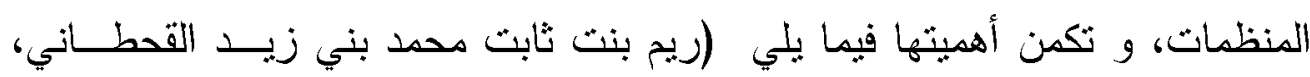
: (OV ، 07 , 4.19

ا ـ إيجاد قيمة كُضافة تُلبي احتياجات العملاء و تضمن و لاءهم و تحسن من سمعتها لديهم . لد. 
r. تحقيق التمبز في الاستراتيجيات و الخــدمات و المــوارد و الكفــاءات علـى المنافسين.

r. تحقيق حصة سوقية و تحصيل مكانة متميزة في السوق في ظل المنافسة الثنديدة.

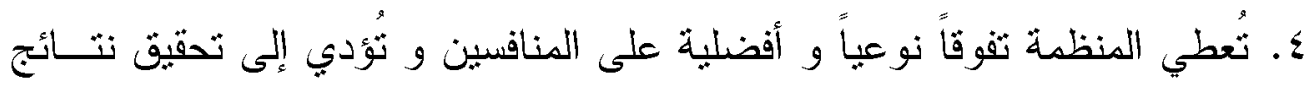
أداء عالية .

ه. تتسم الميزات التتافسية بالاستمر ارية و التجدد بما يُنيّح للمنظمة مُتابعة الثطور و

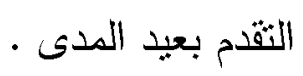

و تكمن أهمية الميزة النتافسية في أنها تُساعد الجامعات على ثحسين أدائها و رفع كفاءتها و ثعزيز ثواجدها في الأسواق، و تثمثل أهمينها في (عيبــر فــاروق

$$
\text { أكبر، }
$$

توفير بيئة تنافسية تُساعد الجامعات على الارثقاء بنوعية مخرجاتهــــا النعليميــة

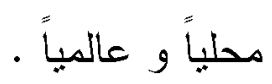

> خلق قيم جديدة للعملاء تلبي احتباجاتهم و تضدن ولائهــم و تُحسـن ســمعة و

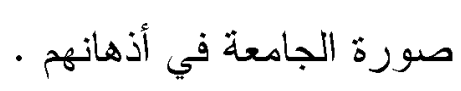

> التحسين المستمر لأداء الجامعة من خلال الابتكارات التكنولوجية لتحقيق التمبز

$$
\text { على المنافسين }
$$

> تحقيق التميز الاستر اتيجي على الجامعات المناقسة فــي الخـدمات التعليميــة و

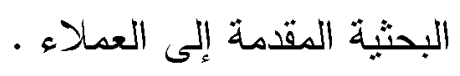

و يرى الباحث أن أهية الميزة التنافسية للجامعة تتبع من خلاهل قدرة الجامعـة على استغلال موارد الجامعة سواء المادية و البشرية، و نتعلق بتطبيق معايير الجودة

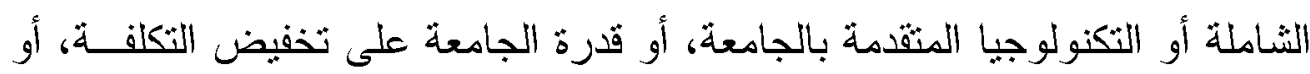
رفع الكفاءة التسويقية للجامعة، و عقد شر اكات إستر اتيجية مع كافة قطاعات الإنتاج،

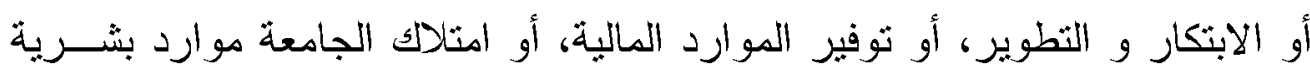

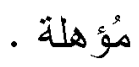




\section{أهداف الميزة التنافسية الجامعية:}

تعني المبزة التتافسبة: قدرة المنظمة على تحقيق رغبات المستهلكين، فالمستهلك هو الحكم في السوق، وإرضائه يُمنل الهدف الإستراتيجي الذي تشــى المنظمــات

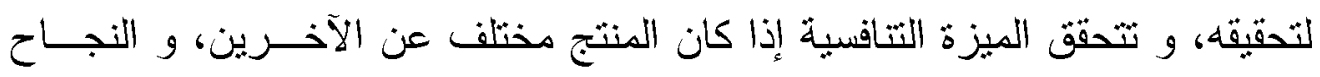
بكون بتحقيق الأرباح، و زيادة القدرة على حماية المنتج من الثقليد و المُحاكاة.

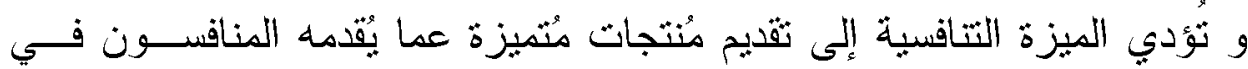
السوق، و تخفيض تكاليف الإنتاج، وتحسين ربحبة المنظمــة مـن خــلال زيــادة

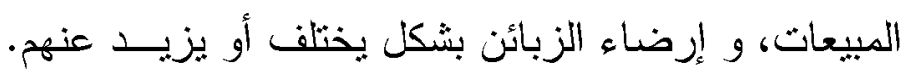

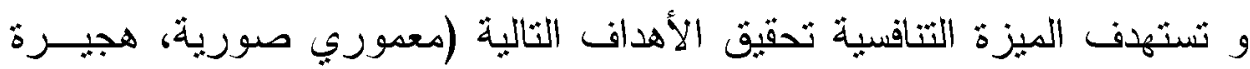

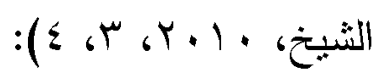

ا. خلق ثيمة للعملاء تلبي احتباجاتهم و تضمن و لائهم و تدعم و تُحسن سـمعة و صورة المنظمة في أذهانهم. r. تكوين رؤية مستقبلية جديدة للأهداف التي تُريد بلوغها و للقرص الكبيرة التـي

$$
\text { تز غب في اقتناصها. }
$$

r. تحقيق حصة سوقية للمنظمة و ربحية عالبة للبقاء و الاسنثمار في السوق •

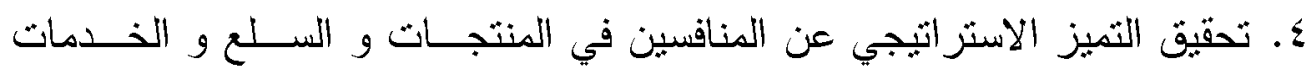

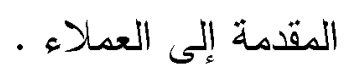
ه. إيجاد فرص تسويقية جديدة (مثال: شركة Apple الثي كانت أول من ابتكـرت

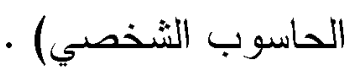
ج. تُططي دينامبكية للعمليات الداخلية للمنظمة نظراً لكونها أداة مستندة على مــوارد

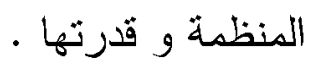
V. دخول مجال ثتافسي جديد كدخول سوق جديدة أو التعامل مع عدـلاء جــدد أو نوعية جديدة من المنتجات. و تُؤدي الميزة التنافسية للجامعة إلى تفوقها على الجامعات المنافسة، فيكون لها

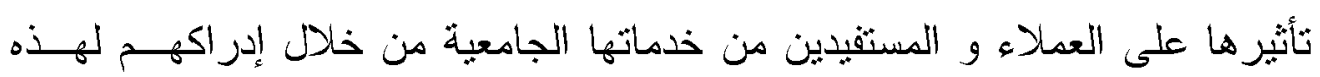




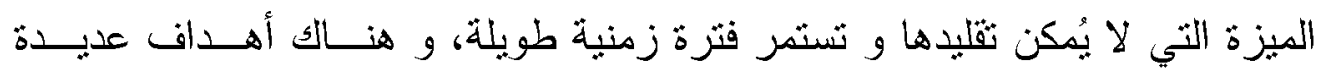

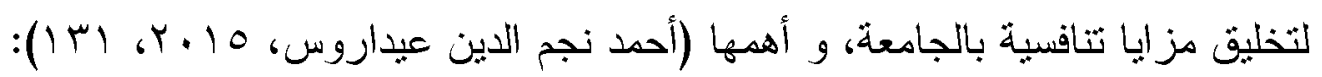
ا ـ تخليق و بناء ميزة تسويقية جديدة للمنتجات و الخدمات الجامعية .

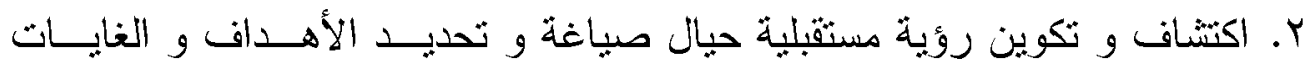
الجامعية . الن.

ب. تجويد آلبات التواصل و الثراكات المهنية تعليمياً و بحثياً و إدارياً و وطنيــاً و دولياً. ــ الإبقاء على أيقونة الإبداع بما يُحقق للجامعة استدامة الصــدارة العالمبـة بــين

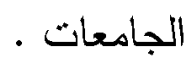

ه. التسويث الأهثل للانتاجية الجامعية تعليماً و بحثباً و إدارياً على المستوى الوطني

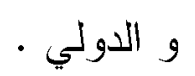

و يرى الباحث أن الميزة النتافسية للجامعات لها هدفين أساسين هــا: الهـدف الأول: تحقيق التميز على المنافسين من خلال تقديم منتجات و خدمات جامعية عالية الجودة في الوقت المطلوب الذي يُحقق رضا العملاء و المستفبدين، و الهدف الثناني

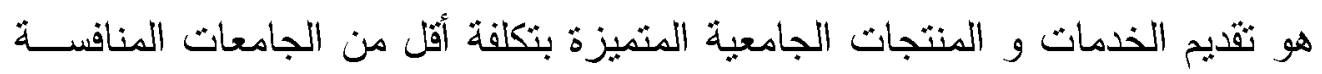

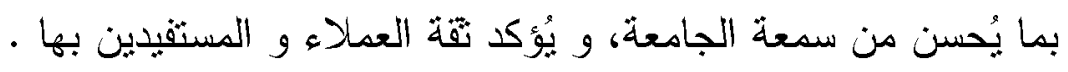
خصائص الميزة التتافسية الجامعية: عند الحديث عن خصائص الميزة التنافسية لابد من التركيز فـــي المة فــام الأول

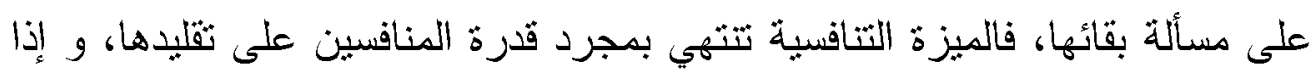
ما أرادت المنظمة أن تُحافظ على الميزة التنافسية فيجب عليها ثبنـي اســـرة اتيجيات تجعل عملية ثقليد الميزة التتافية التي قامت ببنائها عملية شديدة الصعوبة ومرتفعة

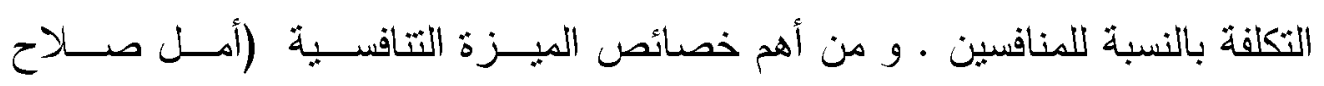

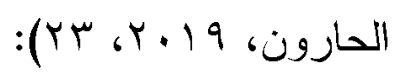
1. أنها مُسنمرة و مُستدامة بمعنى أن تُحقق المؤسسة السبق على المدى القصــير و المدى الطويل . المه مل 
r. أنها تثسم بالنسبية مقارنة بالمنافسين أو مقارنتها في فترات زمنبة مختلفة . ب. أنها مُتجددة وفق معطبات البيئة الخارجية و قدرات و موارد المؤسسة الداخليــة

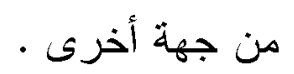

ء. يتتاسب استخدام هذه المبزات النتافسية مع الأهداف و النتائج الني ثُريد المنظمة تحقيقها

ه. تشتتد الميزة التتافسية على موارد المنظمة و جدار اتها و هذا يُعطـي ديناميكيــة للعمليات الاخلية للمنظمة. T. أنها مرنة بمعنى يُمكن إحلال ميزات نتافسية بأخرى بسهولة وفـق التغيــرات

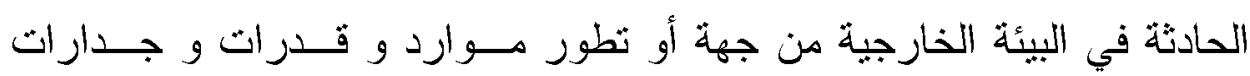
المنظمة من جهة أخرى.

و من أهم خصائص الميزة النتافية أيضاً ما يلي: أنها ثُشنق من حاجات و

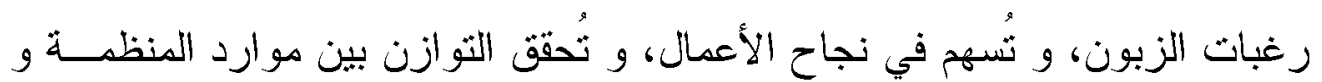

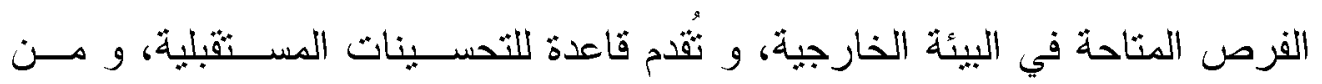
الصعب تقليدها من قبل المنافسين، كما تثصف بالديمومة و القوة، و تُؤدي إلى تحقيق

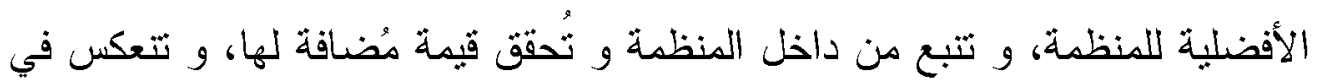

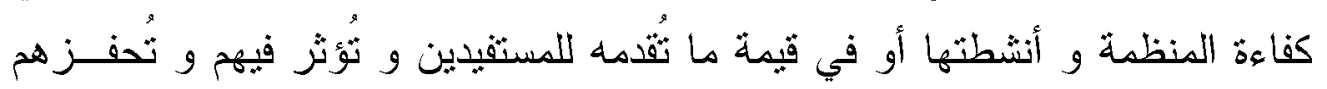

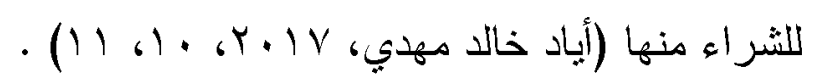

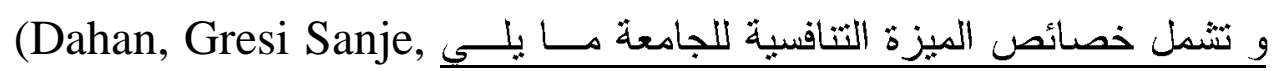

:Senol, Isil, 2012, 95)

ا ـثفرد الجامعة بأصولها الإستراتيجية (هيئة التدريس و الإداريـين و الطـلاب و

مواردها المادية و الثقنية).

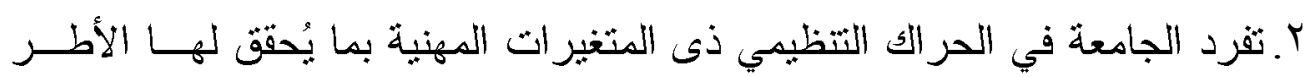

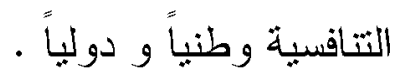

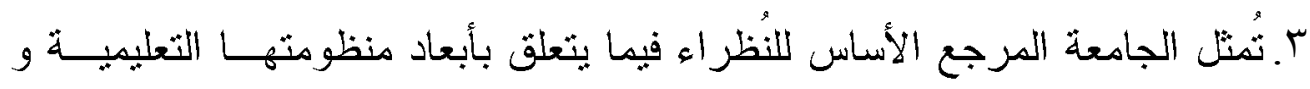

$$
\text { البحثية و الإستر اتيجية. }
$$


متطلبات تطوير الميزة التتافسية لجامعة أسوان في ضوء الاتجاهات العالمية المعاصرة

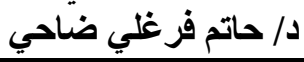

ع. ثميز الإنتاجية المؤسسبة للجامعة بالأفضلية مقارنة بالمنافسين بما بُحةـق أعلـى

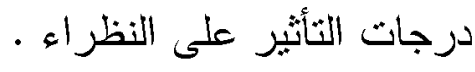

ه.زيادة قدرة الجامعة على البقاء و المنافسة و الاستجابة لحاجة المجتمع إلى خريجين بمو اصفات عالية الجودة

و حتى تشنطيع الجامعة أن تُنافس بكفاءة في أسو اقها الداخلية و الخارجية فإنهـا

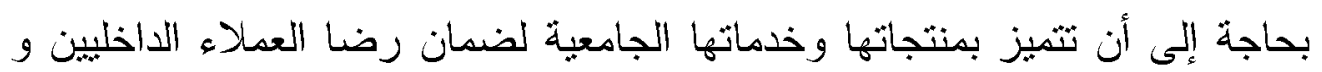

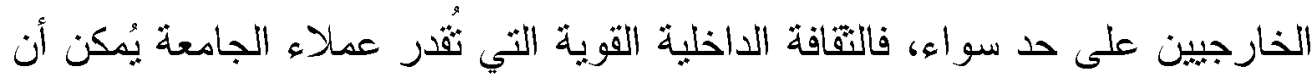

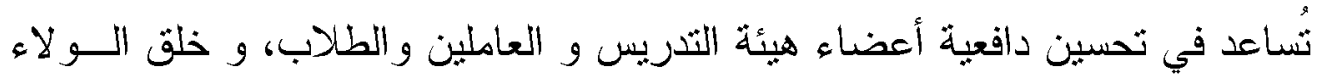

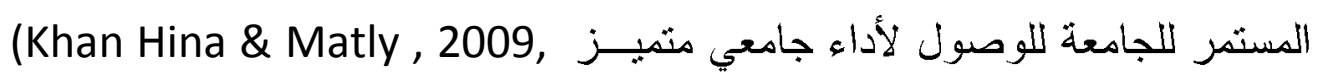

.769-770)

أنواع الميزة التنافسية الجامعية:

تعني الميزة التتافية أداء المنظمة لأنشطنها بصورة أكثر كفاءة و فاعلية، و

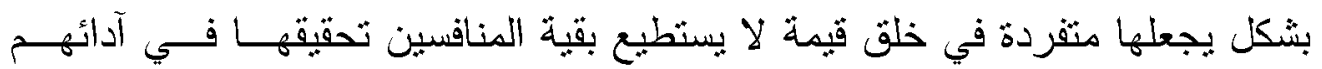

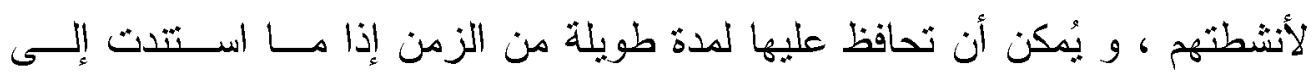
عمليات معرفية ذات منهجية إدارية و اضحة .

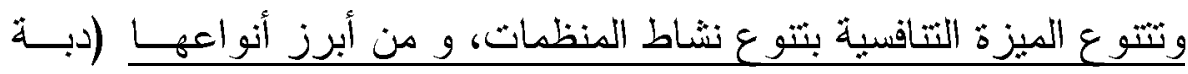
شيما، س) ا.ـميزة التكلفة الأقل: و تعني قدرة المنظمة على تصميم و تصنيع و تسويق منـتنج

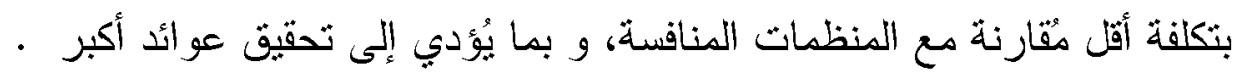

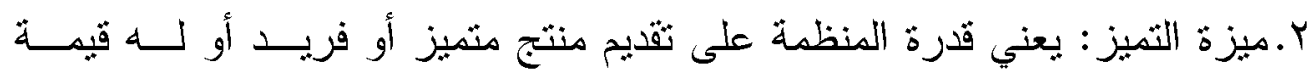

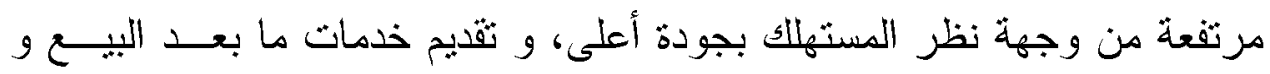

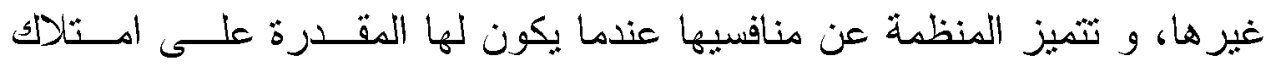
خصائص نوعية تجعل الزبون بتعلق بها، و من أهم دصــادر تمبــز المنــتج أو

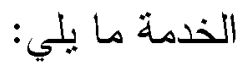


متطلبات تطوير الميزة التتافسية لجامعة أسوان في ضوء الاتجاهات العالمية المعاصرة

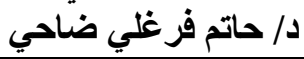

النوعية: تعني قدرة المنظمة على إنتاج منتج عالي الجودة مقارنة بمنتجــات المنظمات المنافسة.

سرعة التسليم: يعني إتاحة المنتج للمشتري عند الطلب دون تأخير .

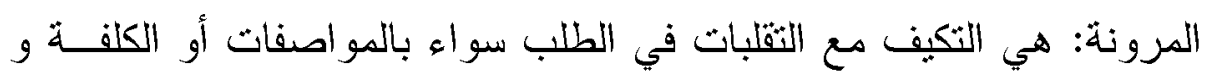

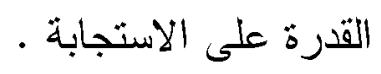

الابتكار: تعني قدرة المنظمة على ثقديم منتجات جديدة من حيث التصميم أو أو

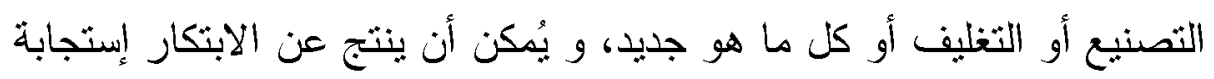

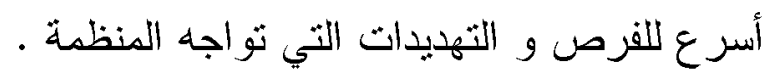
و تشمل المبزة التتاقسية للجامعة كل مجالات الثفوق الثي ثتثنع بها الجامعة مـن

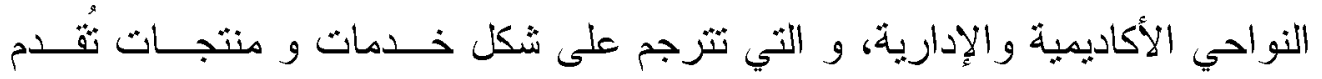

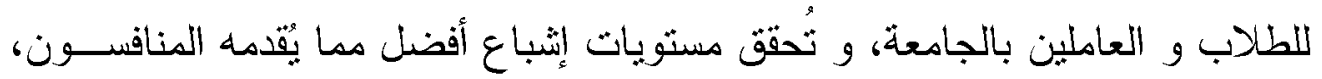

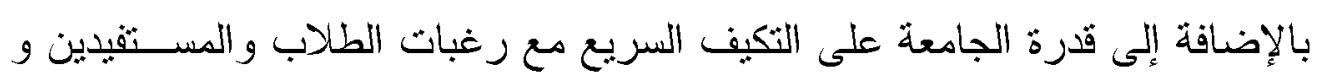

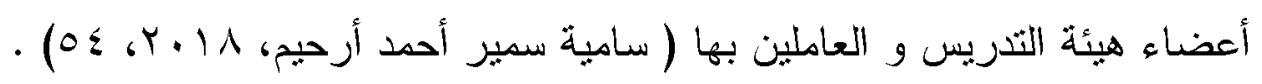

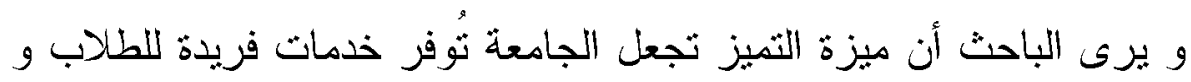

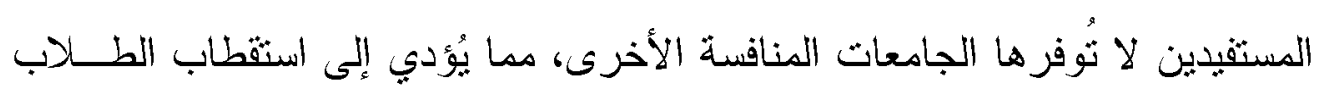

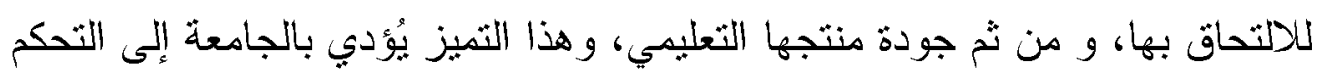

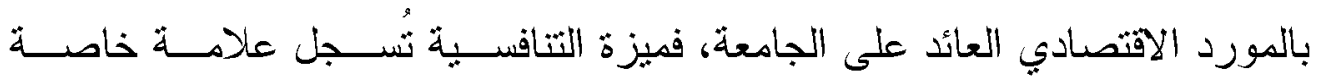
بالجامعة على المستوى المحلى كسمعة الجامعة المنميزة. عناصر الميزة التنافسية الجامعية: تُعد الميزة التتافسية القوة الدافعة لتحديد مسار ات المنظمة، و تُشكل عامل نجـــاح

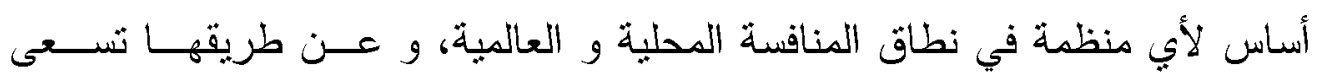

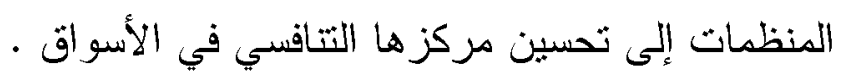

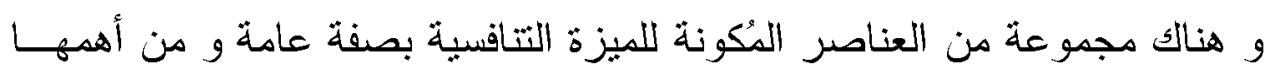

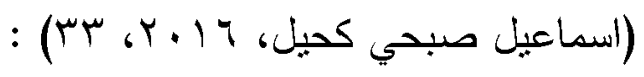


ا. الموارد الطييعية: على الرغم من أهمية نوافر الموارد الطييعية لتحقيق الميـزة

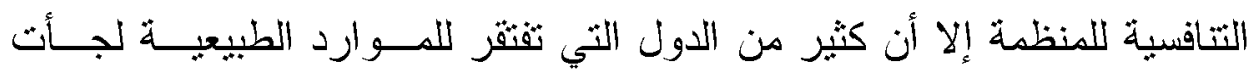
للاستثمار في العقول كاليابان على سبيل المثال . r. رأس المال: كان نوافر رأس المال في المنظمات قادراً على تحقيق ميزة تنافسية عالية، و لكن مع الاقتصاد العالمي الجديد نز اجعت أهميثه في تحقيق المنافسة . r. الموارد البشرية: يُمثل العنصر البشري ذو التعليم المثميز و المهارة العالية بُعداً

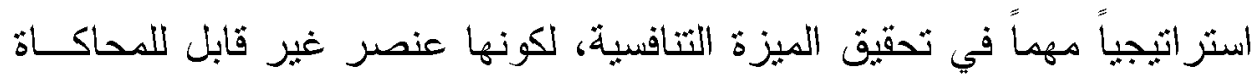

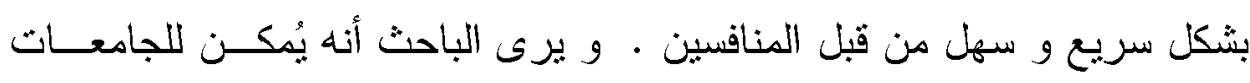
تفعيل دور العنصر البشري في تتمية قدرتها التتافسية من خلال تعزيز قيم تثافية

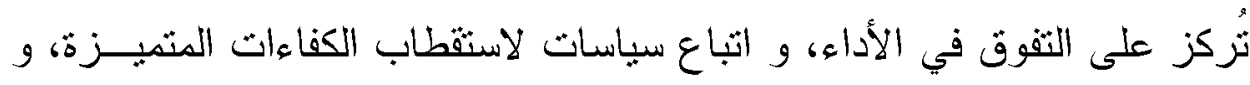
توفير مناخ تتظيمي مُحفز لباقى العاملين في الجامعة، و تطبيق التمكين الإداري

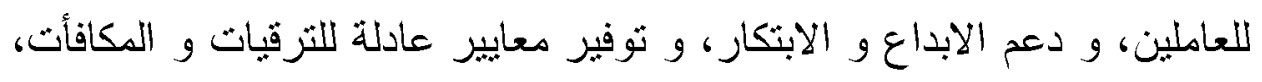

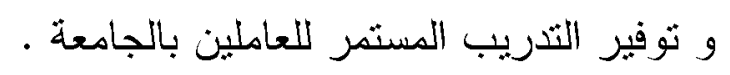
ع. التكنولوجيا: بلعب العنصر التكنولوجي دوراً مهماً في نحسين الكفاءة الإنتاجية،

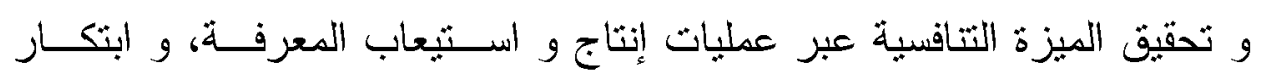

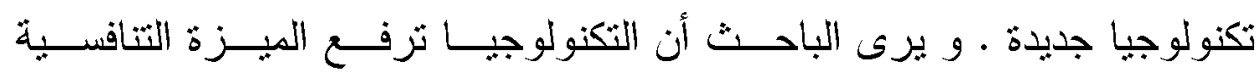

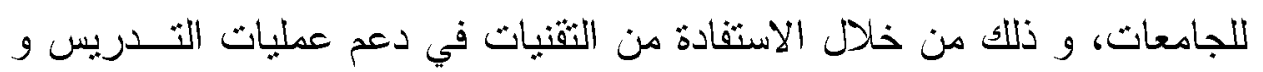

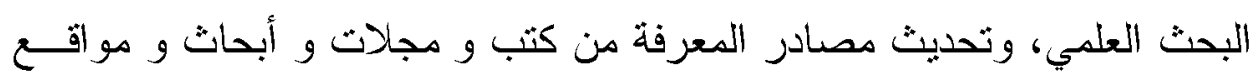

$$
\text { إلكتزونبة . }
$$

مؤشر ات تحقيق الميزة التنافسية الجامعية:

إن المحللين الاقتصاديين بعثدون في ثقييمهم للوضع التتافسي لكل منظمــة

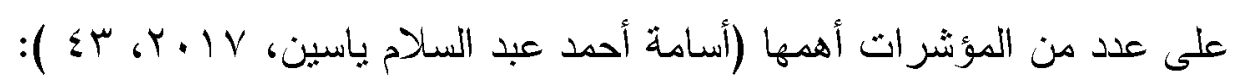

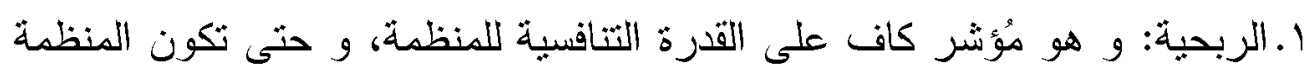

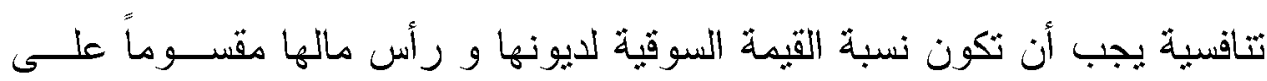

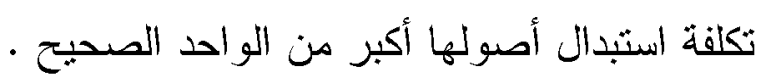


Y.نكلفة الصنع: يُمكن اعتبار تكلفة الصنع بالقياس إلى نكلفة المنافسين مُؤشر كافي

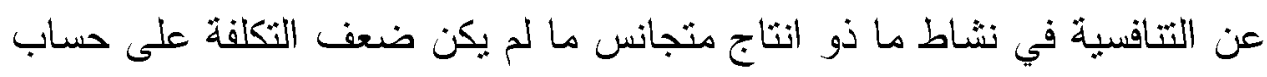
الربحية المستقبلية .

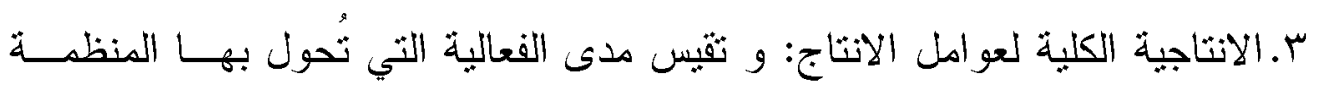
عناصر الإنتاج إلى منتجات.

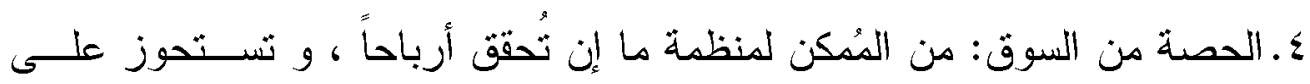

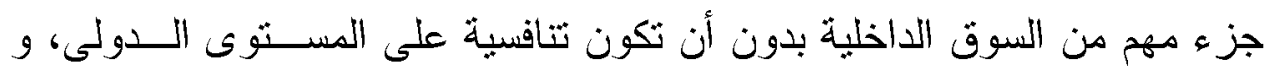
كلما كانت التكلفة الحدية للمنظمة ضعيفة بالقياس إلى التكلفة الحدية لمنافسيها كلما كانت حصنها من السوق أكبر ، و كانت أكثر ربحية مع افتراض ثناوي الأمور الأخرى، فالحصة السوقية تُرجم لمز ابيا في الإنتاجية أو في تكلفة عوامل الإنتاج. و تثمثل أهم مؤنشرات قياس الميزة التتافية للجامعات بعدة مجالات هــئ(نجلاء

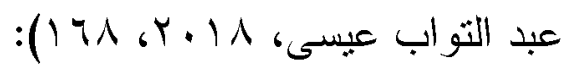

1. البحث و الاستكثاف: و يتضمن مؤشرات مثل : النشر في المجلات العلمبــة ،

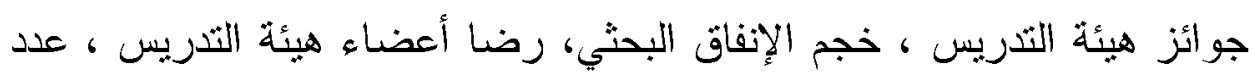

$$
\text { درجات الدكثور اه الممنوحة سنوياً. }
$$

r. التعليم و التعلم: و يتضمن مؤشر ات مثل: جودة الطلاب، و التتوع بين الطلاب ،

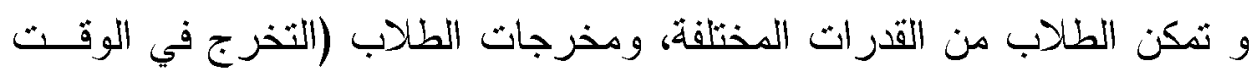
المناسب، الدرجات الممنوحة)، و المشاركة الدولية (عدد المنح و أعداد الطلاب الدوليين و الأساتذة الدوليين)، مُشّاركة الطلاب في البحوث الجامعية.

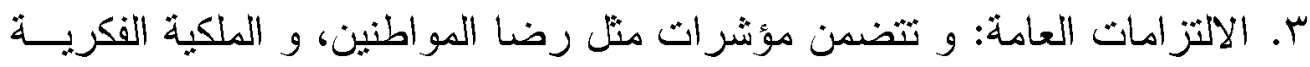

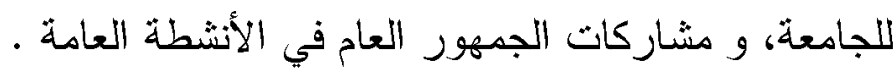

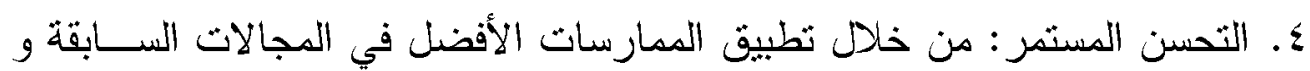
تعزيز ثقافة تتظيمبة فعالة ملتزمة بالتميز و الاستجابة للتغيير •

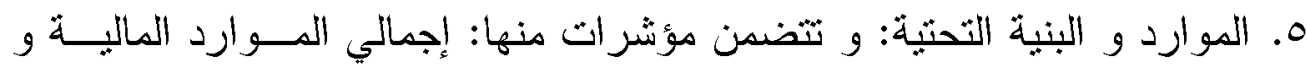

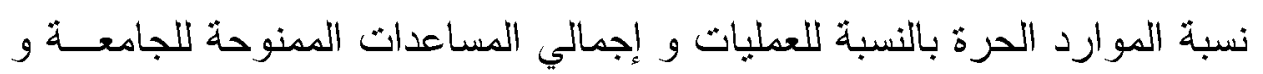


متطلبات تطوير الميزة التتافسية لجامعة أسوان في ضوء الاتجاهات العالمية المعاصرة

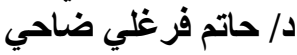

الوقف أو الثبرع السنوي للجامعة و جودة المكتبة و المساعدات و التشهيلات و رضا الموظقين و المرتبات و مكافأت أعضاء هيئة التدريس .

و هناك عدة مؤشرات لقياس القدرة التتافسية للجامعة ، و هي : جودة المنتجات الجامعية المُقدمة للعملاء و المستقبدين و تقديمها لهم في الوقت المناسب، و مسـنتوى

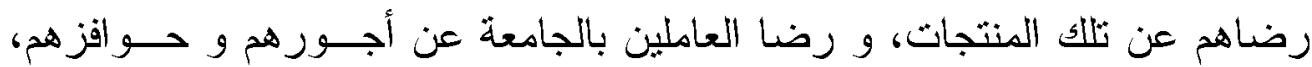
و انتماءهم للجامعة و اعنزازهم بالعمل لديها، و تثديم خدمات جديــدة للمســثفيدين، وإيجاد طرق مبنكرة في ثسويق الخدمات الجامعية، و إدخال التحسينات المستمرة في تكنولوجيا العمل، وإجزاء تغيرات تتظيمية تنتاسب و الظـــروف اليئيــة المحبطـــة

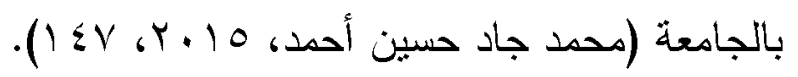

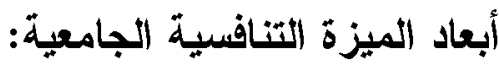

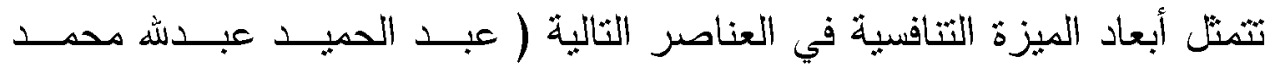

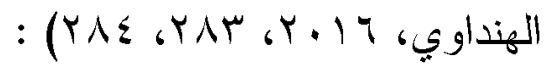

ا. الكفاءة العالية: يقصد بها قدرة المنظمة على انتاج السلع و الخدمات بتكلفة أقــلـل

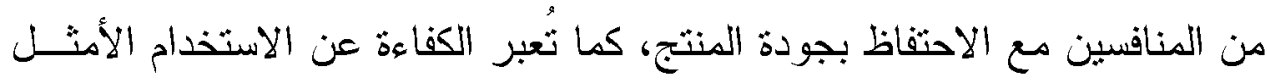
للمو ارد، و تثحقق عند استخدام أقل كم مُكن من الموارد و المدخلات لإنتاج أكبر

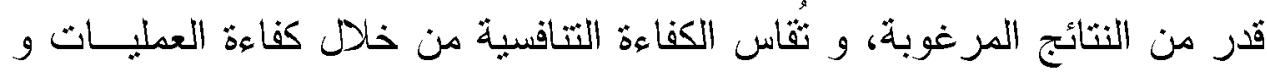
معدل الأرباح و الحصة السوقية، فكلما ارتفع معدل كفاءة المنظمة زادت جودثها الإنتاجية .

r. الجودة العالية: تُشير إلى أداء الأشياء بصورة صحيحة، و ثقديم منتجات نـتنلاهم

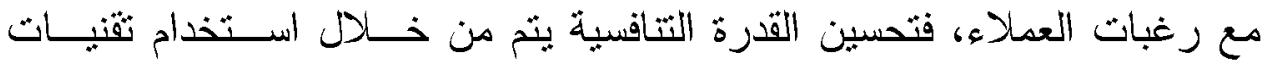
مثعددة، منها: إعادة هندسة العمليات، و إدارة الجودة الثاملة، فالعملاء برغبـــون

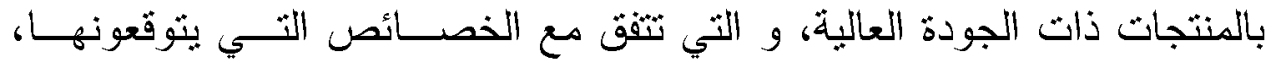

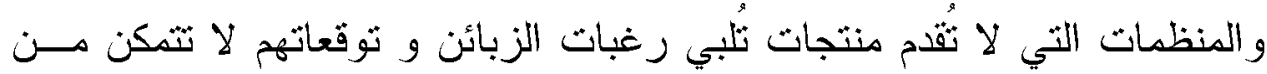
البقاء في دائرة المنافسة . 
ب. الاستجابة السريعة للزبون: و تعني قدرة المنظمة على تنفيذ أعمالهــا بصــورة

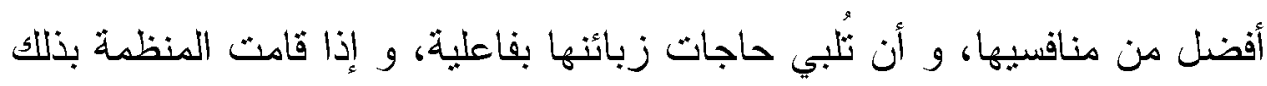

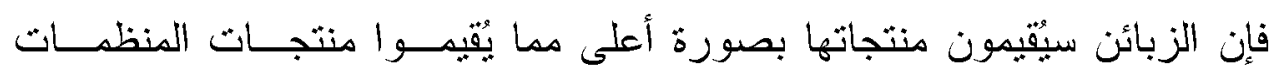

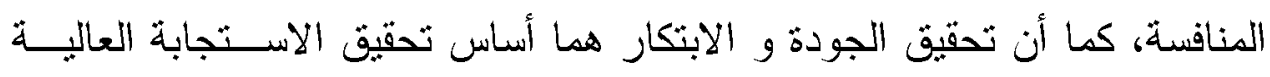
للزبون، بالإضافة إلى عامل آخر مهم هو صنع المنتج و ثقديم الخدمة حسب طلبه

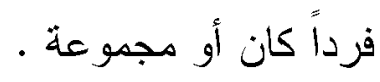
ـ. الإبداع و الابنكار : بتضمن الابداع تتويع المنتجات و الإبداع في عمليات الانتاج

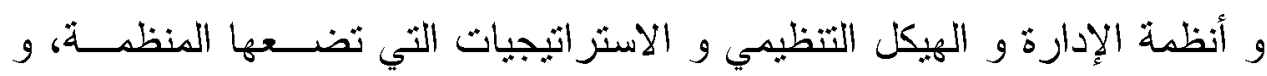

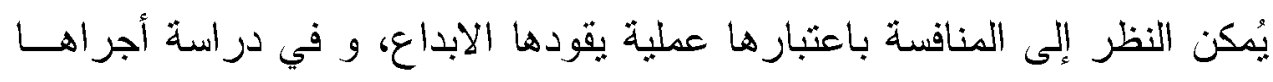
Porter

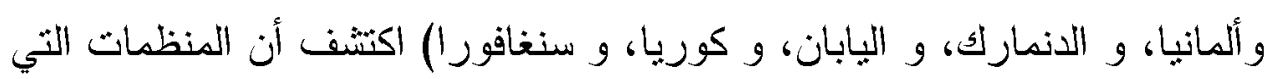

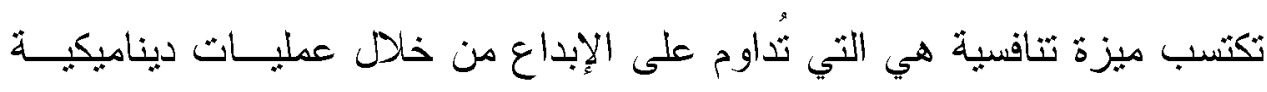

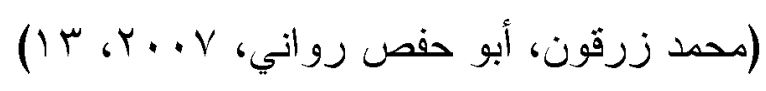

\section{و مما سبق يتضح أن أبعاد الميزة التنافية الجامعية تثمثل في :}

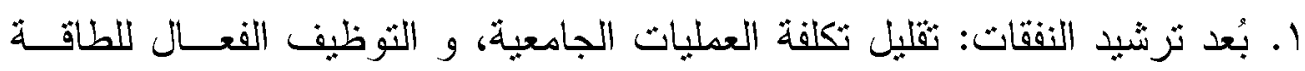

$$
\text { الإنتاجية المادية و البشرية . بانية }
$$

Y. بُعد الجودة: تُقدم الجامعات منتجات و خدمات عالبة الجودة تُطابث المواصفات

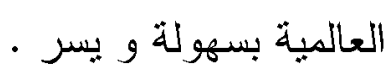

ب. بُعد الإبداع: يرتكز على إنتاج أفكار جامعية جديدة و تتفيذها و إيجـاد حلــــل بـول

جديدة للمشكلات.

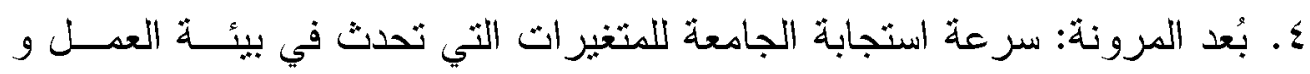

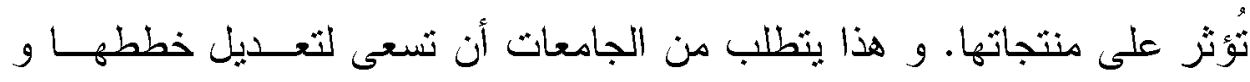

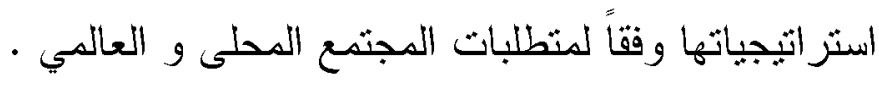


ه. البعد الزمني: بعني التزام الجامعة بالوقت المحدد و سرعة تطوير منتجاتهـا و

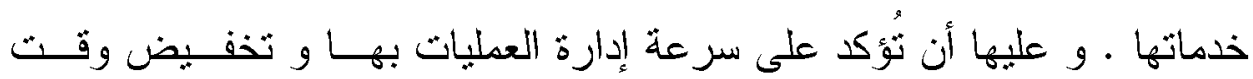

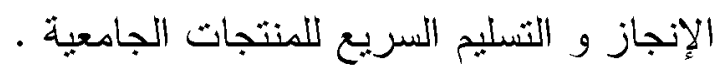

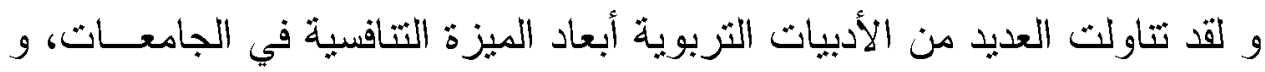

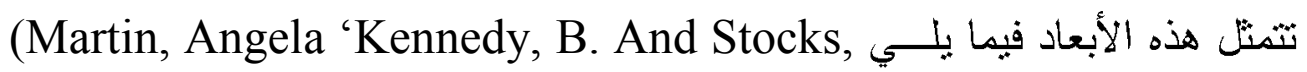
:Belinda, 2006, 139 -141

ا ـالنوعية و الجودة التنافسية: ثمثاز الجامعة التي تثخذ من الجودة أسبقية نتافسـبة

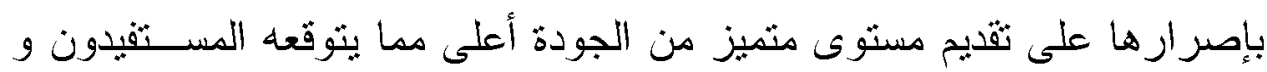

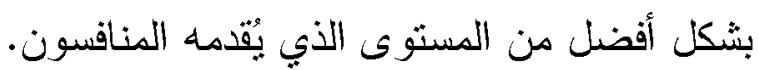

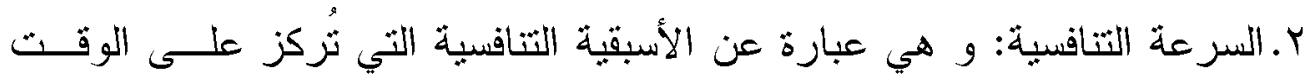
كأساس لتحقيق المبزة التتافسية، و هي: وقت التخرج للطلاب المثوائم بين خطط

$$
\text { الجامعة و اتفاقياتها مع إدارات التربية و التعليم . }
$$

r.التميز التتافسي: و تشمل على عاملين هما: قدرة التميز على المنافسين هن خلاله

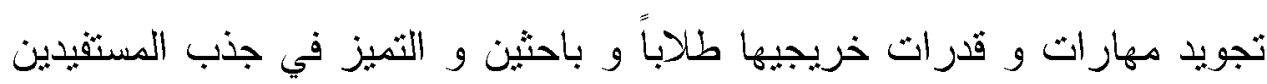

$$
\text { بتجويد خدماتها المؤسسية . }
$$

ـ. الابتكار النتافسي: و بعني طبيعة التغيرات التكنولوجية الجديدة اللازمة لسد حاجة السوق و تحقيق الميزة النتافسية للجامعة، و يُمكن تحقيق الابتكـار مـن خـلال الفرص الجديدة في البيئة الخارجية .

هـ المرونة التنافسية: و تعني القدرة على الاستجابة للتغيرات المنعلقة بسوق العمـلـل من خلال نطوير قدرات الخريجين و الهيئات التذربسـية و الإداريــة، و ثقبــبم الخطط الاستر اتيجية للجامعة وفقاً للمقتضبات المهنية .

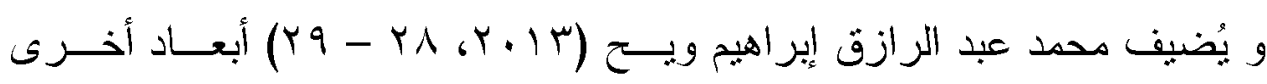
للميزة التنافسية للجامعة و هي: 
ا. الثركيز على الطلاب: أبي تحقيق القدرة على الحفاظ على الطــلاب الحــاليين، و القدرة على جذب طلاب جدد في المستقبل، و هذا بتطلب حساسية من قبل الإدارة

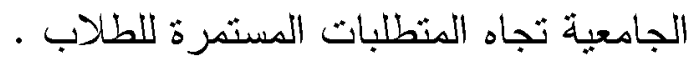
r. التحسين المستمر: أي التطوير الدائم لكل مكونات الجامعة من أجل نحقيق جودة

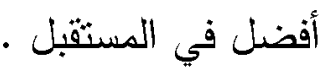

r. مشاركة أعضاء هيئة التدريس: يعثمد نجاح الجامعة في تحسـين الأداء بشـــل

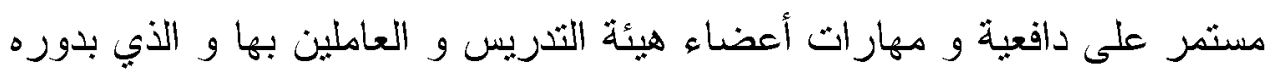

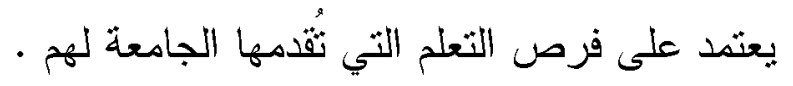

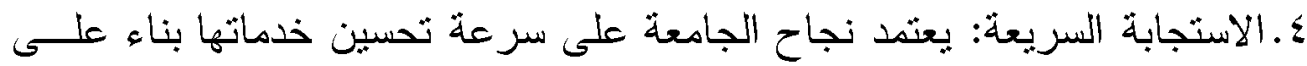
رغبات العملاء و المستفيدين • ه.الإدارة بالحقائق: ثقوم الميزة الثتافسية على بيانات و حقائق ضرورية من أجـلـ التحسين المستمر. ج. تطوير المشاركة: سعي الجامعة إلى بناء شر اكات ناجحة مع مؤسسات المجتـــع لإنجاز أهدافها بفاعلية. V. المسئولية الاجتماعبة: هناك مسئولية تتحملها الجامعة تجاه المجتمع الذبي تعدـلـ فيها و تخدم قطاعاته. و هذه الأبعاد ثربطها علاقات منشابكة و لكل منها تأثير على البعد الآخــر فـي تكامل يحدث معه تكوين مزايا تتافسية ، كما أن هذه الأبعاد نرتبط بالكفاءات البشرية

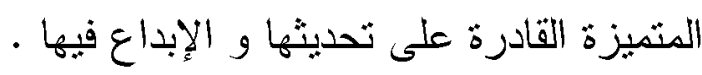
مصادر الميزة التنافسية الجامعية:

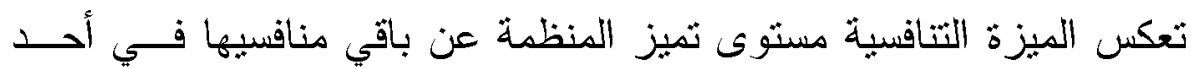

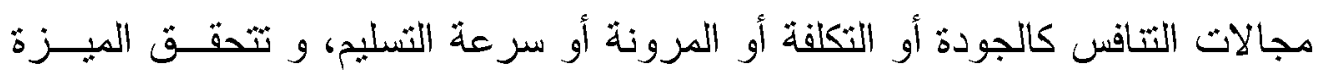

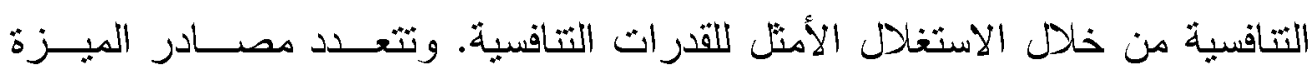

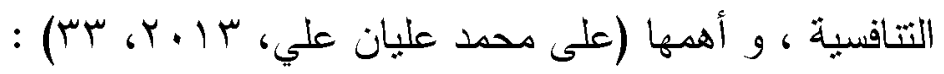


اـالمصادر الداخلية: و هي المرثبطة بموارد المنظمة مثـلـل: العوامـلـل الأساســية

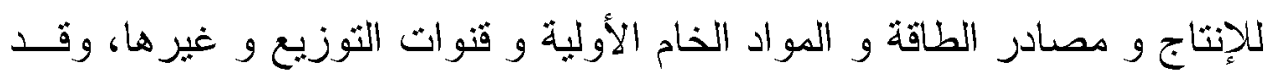

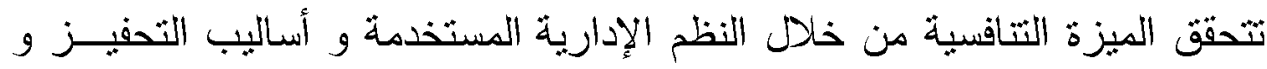
البحث و التطوير و الإبداع و المعرفة . r.المصادر الخارجية: و هي تثشكل من متغيرات البيئة مما يُؤدي إلى إيجاد ميزات تشتظلها المنظمة و تشتفبد منها، مثل ظروف العرض و الطلب على المواد الخام

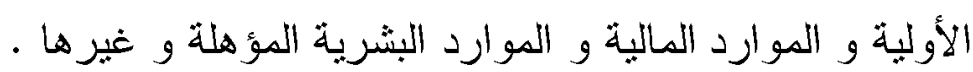

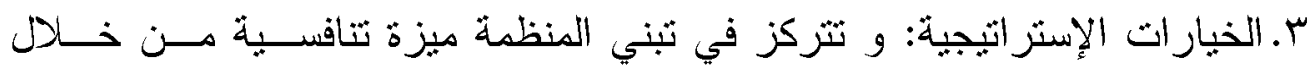

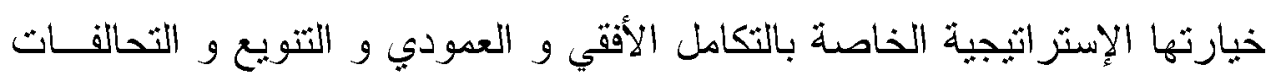

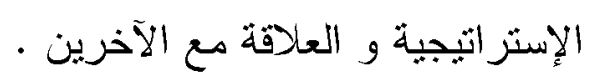

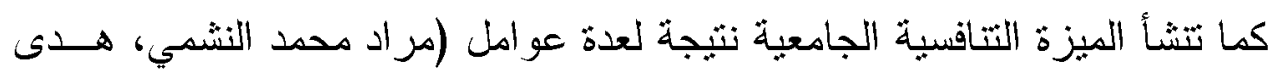

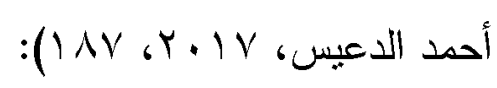

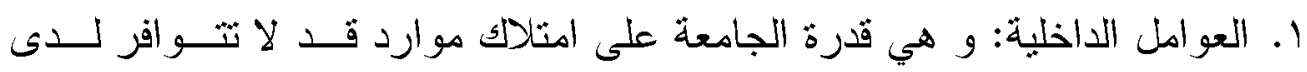

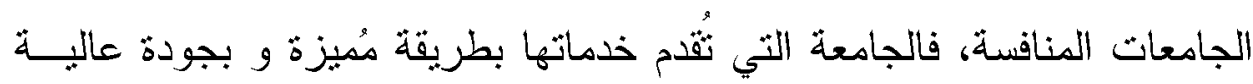

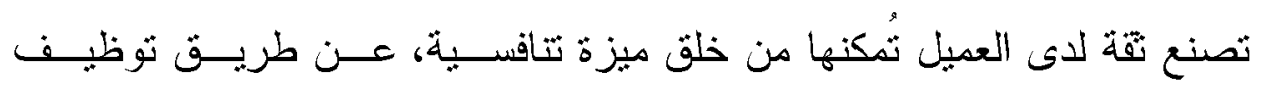

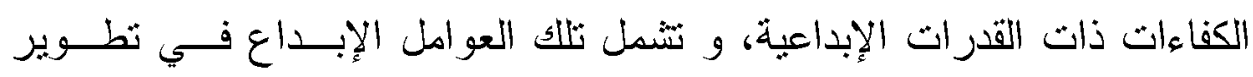

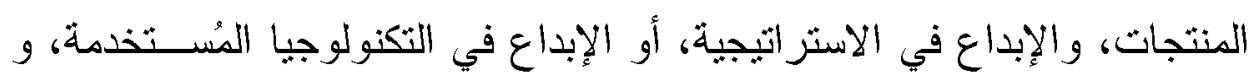
الإبداع في خلق فائدة جديدة للعميل .

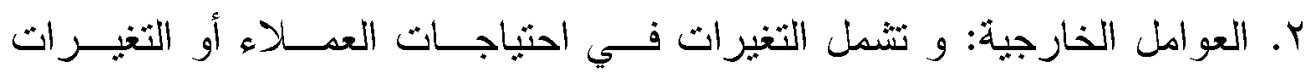

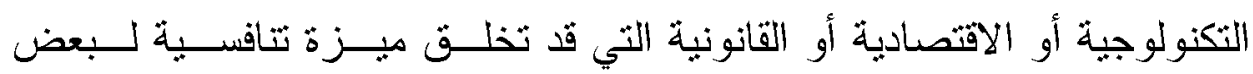

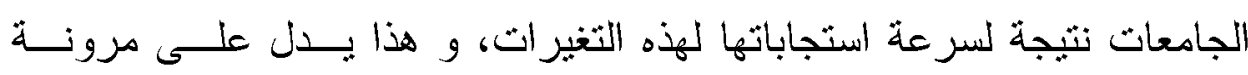
الجامعة، و قدرثها على مثابعة المنغيرات عن طريق تحليل المعلومات و مطابقة

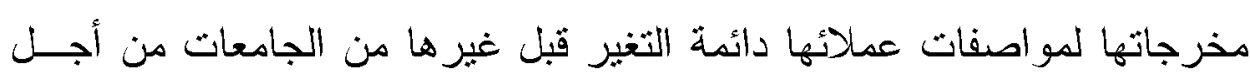
خلق ميزة تنافسية . مجية 


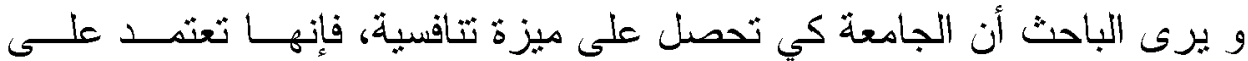

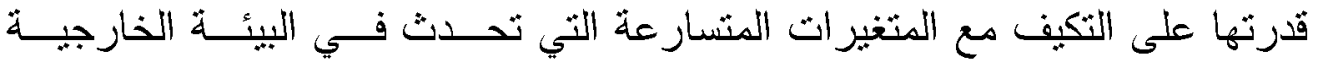

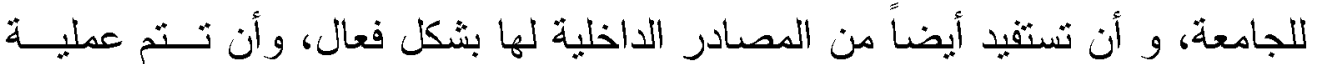
اختبار و نطبيق إستر اتيجيات الميزة التنافسية داخل الجامعة بشكل فعال . كُحددات المبزة التتافسية الجامعية:

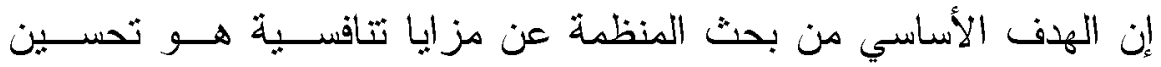

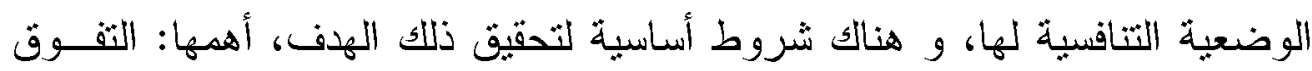

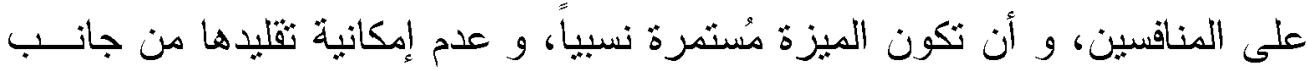
المنافسين، و قياس جودة المبزة التناقسية المكتسبة من خلال معايير معينة.

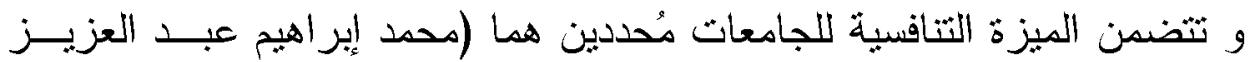

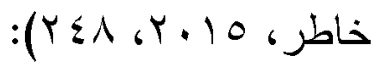

ا.حجم الميزة الثتافسية: تتحقق استمرارية الميزة الثتافسية إذا تمكنت الجامعة مـن

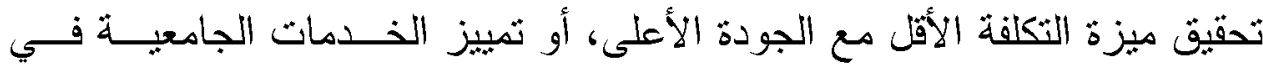

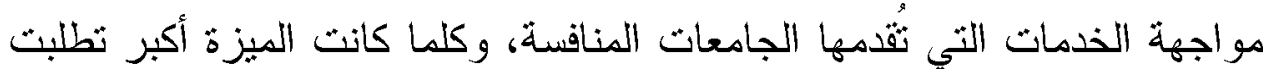

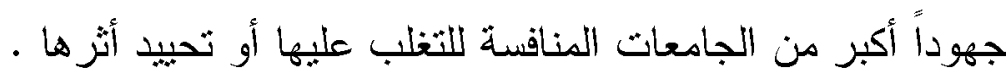

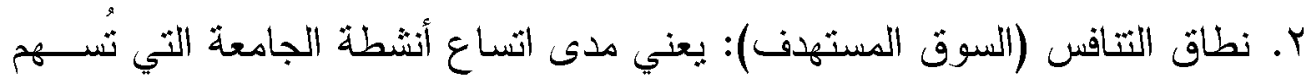
في تحقيق مزايا تنافسية، وذلك بتحقيق وفورات في النكلفة مقارنسـة بالجامعسات المنافسة، كالاستفادة من تقديم تسهيلات إنتاج مشتركة بينهــا و بــين جامعــات أخرى، و الإستعانة بخبرة فنبة واحدة، و استخدام نفس المنافذ الجامعية لثوزيـع المنتجات و الخدمات الجامعية لخدمة قطاعات سوقية مختلفة، مما يُسهم في تحقيق اقتصاديات الحجم، و يُمكن تحقيق ميزة تنافسية للنطاق الضيق من خلال التركيز

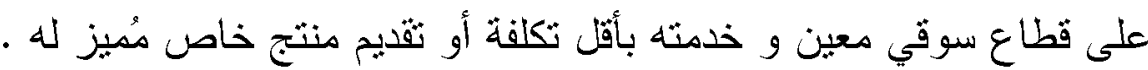
و يزى البعض أن مُحدداث الميزة التتافسية في التعليم الجامعي تكمن فـي :

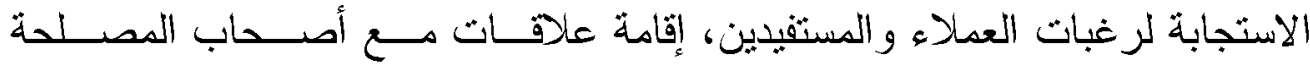
و العملاء ، و الموقع الجغرافي و الذي يُؤثر على العلاقة بـين الجامعسـة و اليئــة 
الخارجية و مدى خدمنها لهذه البيئة، القدرة على الأداء المثمبز الذي بُعطي الجامعة

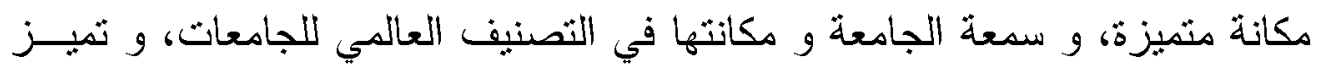

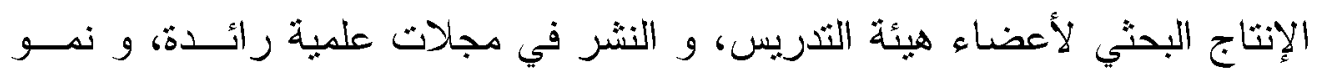

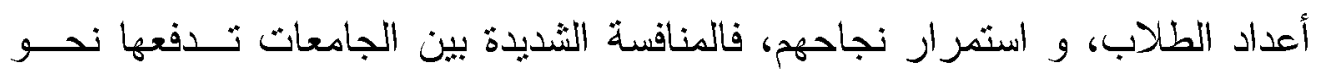

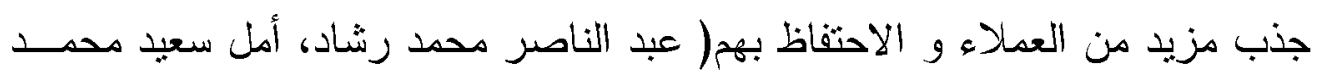

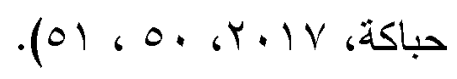

و يرى الباحث أن امتلاك الجامعة للمبزة التتافسية يُزيد مــن البــدائل المتاحسـة

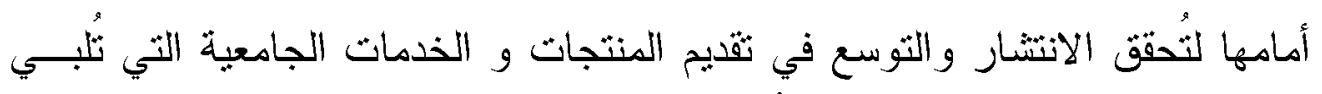

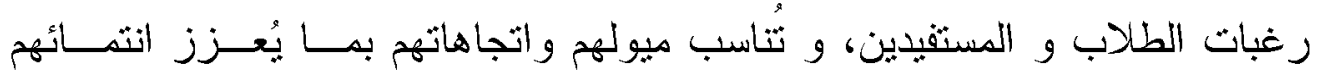
للجامعة، و يُكن الجامعة من تقديم خدماتها باستقرار نسبي يُطيل من عمرها الزمني وني وني

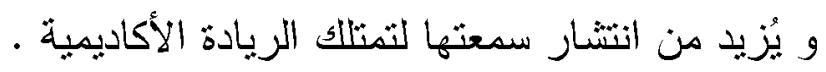
معايير الحكم على جودة الميزة التتافسية الجامعية: و هناك ثلاثثة معايير للحكم على جودة الميزة التنافسية هي (حجاج عبد الرؤوف،

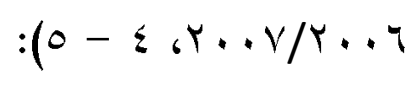

1. مصدر الميزة: هناك نوعين من المزايا وفقاً لهـــا المعيــار : مزايــا نتافسـبـة منخفضة: و هي تعنمد على التكلفة الأقل لقوة العمل و المواد الخام و هي سهلة التقلبد من قبل المنافسين، و مزابا نتاقسية مرثفعة و هي تشتتد إلى ثميز المنـتنج

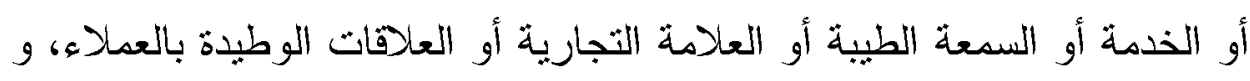
تتطلب هذه المز ايا تو افر مهار ات عالية المستوى مثل ثدريب العمال و الدعايا و الاعلانات التحفيزية .

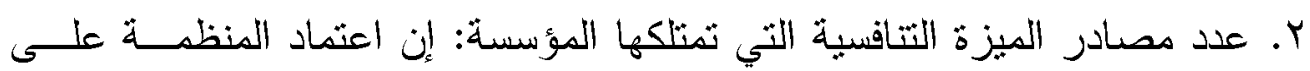

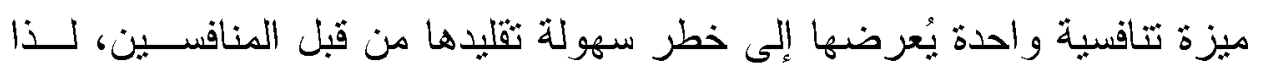
بُستحسن تعدد مصادر الميزة التتافسية . ب. درجة التحسين المستمر في المبزة: ثقوم المنظمات بخلق مزايا نتافسية جديدة و

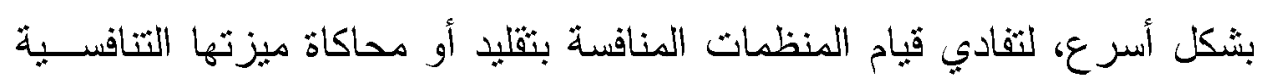


الحالية، لذا تثجه إلى خلق مزايا تتافسية من المرتبة المرتفعة، كما يجب على بـى المنظمة أن ثقوم بثقيم مسنمر لأداء مبزتها التنافسية .

و ينطلب الحكم على جودة الميزة التتافسية الجامعية مجموعة متطلبات أهدها :

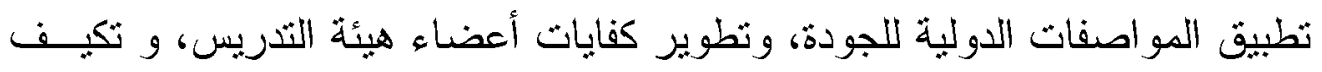

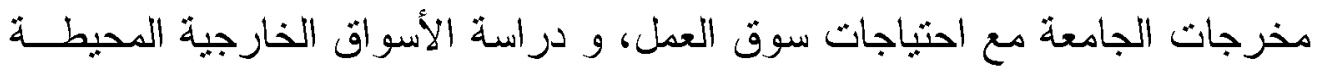
بالجامعة، و نطوير استخدامات ثكنولوجيا المعلومات والاتصالات. إستر اتيجيات تحقيق الميزة التنافسبة الجامعية:

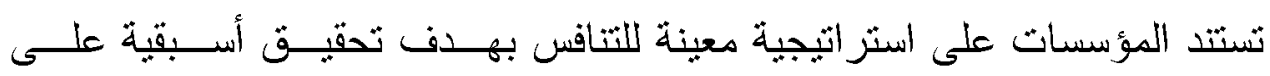

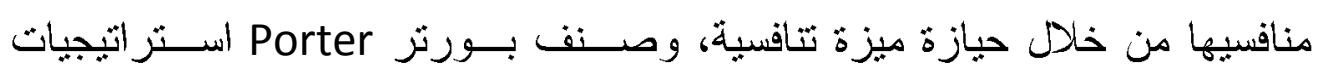

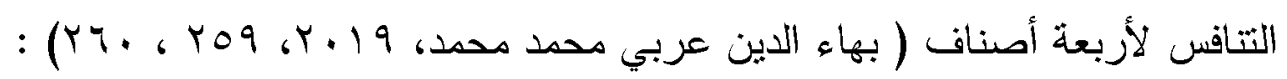
ا ـ استز اتيجيات قيادة التكلفة: و ثهدف إلى نحقيق تكلفة أقل بالمقارنة مع المنافسين،

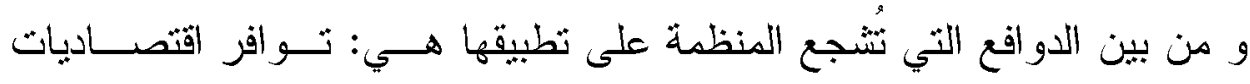

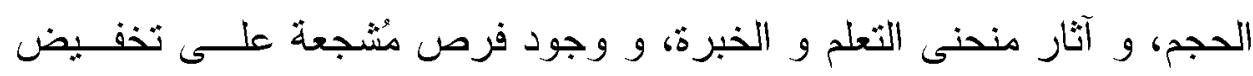

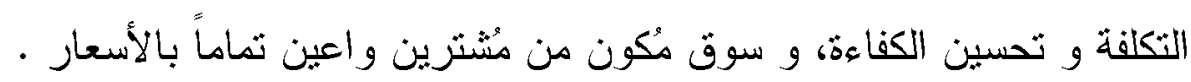

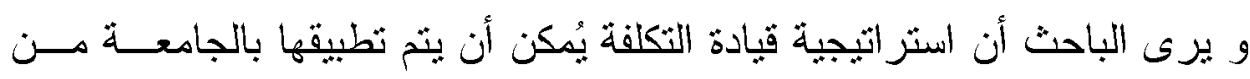
خلال الممارسات الثالية: > حرص الجامعة على تخفيض الرسوم الدراسية لطلابها مقابـلـل الخـدمات و ذلك للحماية من المناقسين. > سعى الإدارة الجامعية إلى تحقيق النتافس مع الجامعات الأخرى بمصروفات من التين مُخفضة . مُخى > نوفير الإدارة رأس مال يسمح بتقديم خدمات منتوعة بتكلفة قليلة يُعد مؤشراً لر أس مال الجامعة. تكاليف الدر اسة المُخفضة تُشكل قوة تفاوضية للجامعــة مـــع الطــلاب لأن أسعار ها مُخفضية. 
Y. استراتيجيات التمايز : تثمايز المنظمة عن منافسيها عنـــما بكـون بمقـدورها

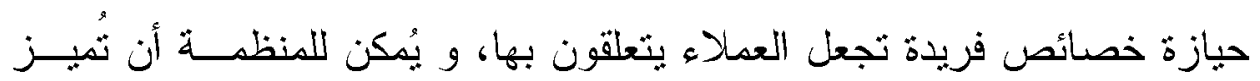

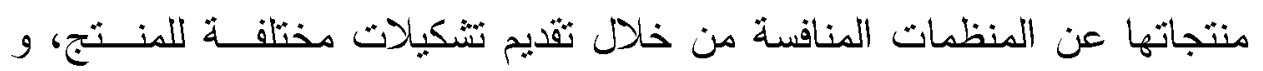

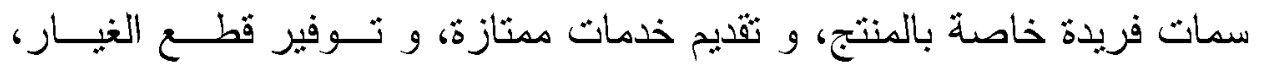
و الجودة المتمبزة، و تحقيق الريادة التكنولوجية، و السمعة الجيدة .

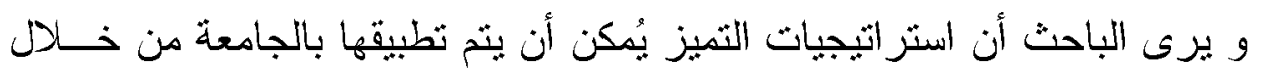

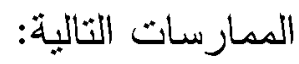

> تلتزم الجامعة بثلبية احتياجات جميع أصحاب المصلحة بجودة عالية .

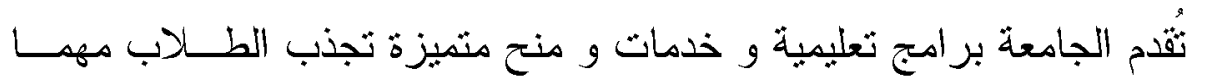
كانت التكلفة . تُشجع الجامعة الممارسات الإبداعبة لدى أعضاء هيئة التـدريس لاكنشــاب الكفاءة العالبة .

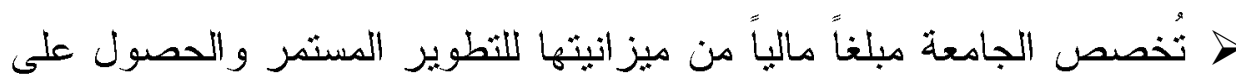
مركز تنافسي قوي > تُوفر الجامعة نكنولوجيا فريدة للتواصل مع العملاء و المسنثرين و أصحاب المصلحة . خ ثُقدم الجامعة خدمات منميزة بأقل تكلفة ممكنة لا ثُقدمها مثيلاتها لضمان و لاء

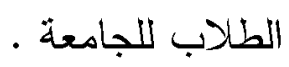
r. استراتيجيات سرعة الاستجابة: يعتمد النجاح في الأسواق التتافسية على تحسين

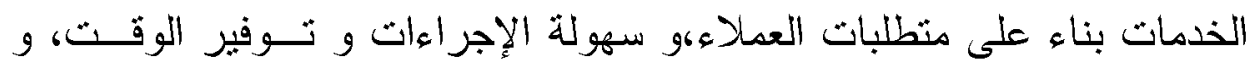
المرونة في إتخاذ القرار الأمثل، و تقديم المبادرات، و تثميز هذه الإســنز اتيجية بمرونة الخدمات، و مرونة الحجم، و سرعة التسليم، و تُحقق مزايا عديدة منها:

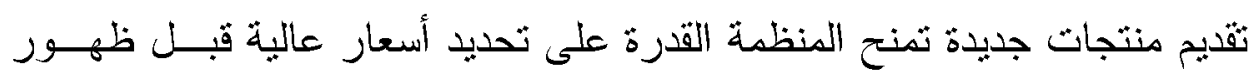

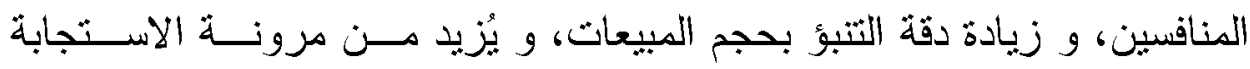

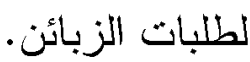


متطلبات تطوير الميزة التتافسية لجامعة أسوان في ضوء الاتجاهات العالمية المعاصرة

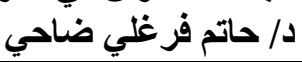

و يرى الباحث أن اسثراتيجيات سرعة الاستجابة بُمكن أن بنم نطبيقها بالجامعة من خلال الممارسات التالية: > التزام الجامعة بتشهيل سرعة وصول المنتجات و الخدمات الجامعبـــة إلــى جميع أصحاب المصلحة .

> حرص الجامعة على تتويع الخدمات المقدمة اســتجابة للتغيــرات الحادثــة المحلية و العالمبية . > منح أعضاء هيئة التذريس و العاملين المرونة الكافية فـي أداء أعــالهم و مهامهم مهر تشنحدث الجامعة تخصصات جديدة و برامج ثعليمية تُبي احتياجات ســوق العمل .

ــ استز اتيجيات التزكيز أو التخصص: تهدف هذه الإستراتيجية إلى بنــاء ميـزة تتاقسية و الوصول إلى مواقع أفضل في السوق، من خلا إثباع حاجات شريحة

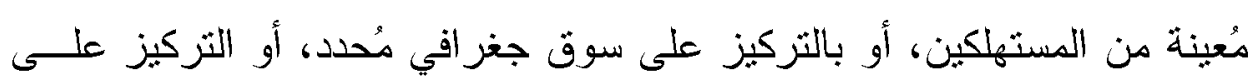
استخدامات معينة للمنتج

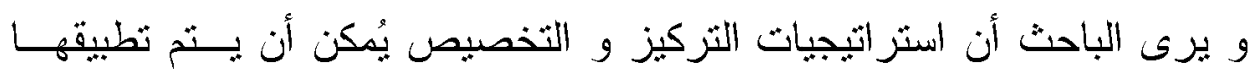
بالجامعة من خلال الممارسات التالية: > تُعامل الجامعة الطلاب بوصفهم محور العملية التعليمية ، و ثنسعى لتلبيــة احتباجاتهم بطريقة فعالة. > حرص الجامعة على تقديم خدمات ذات جودة عالبة للطلاب مهمــــ كانـــ التكالبف > حرص الجامعة على تطوير العلاقة بين الطلاب و العاملين بثكل مسنمر •

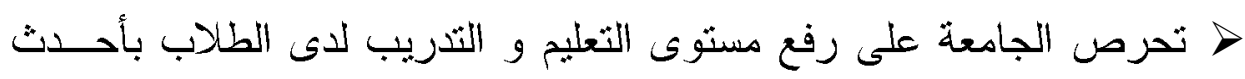

$$
\text { · الطرف }
$$

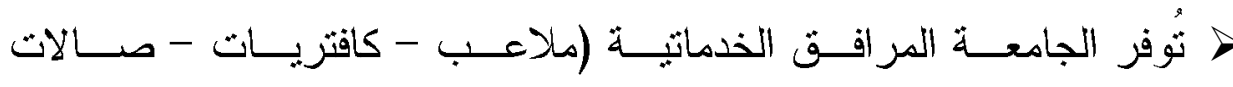

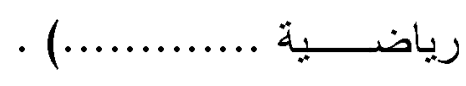


و لا يتوقف تحقيق المبزة التتافسية للجامعة عند اتباع هذه الاســتراتيجيات

فقط، لكن يلزم تفكير اسنز اتيجي في مسنقبل الجامعة، و معرفة نقاط القوة و الفرص

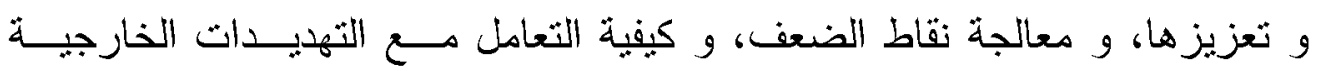
للجامعة، و هذا بوجود كفاءات بشرية مُؤهلة لضمان تحقيق الميزة التنافسية. منطلبات تحقيق الميزة النتاقسية الجامعية:

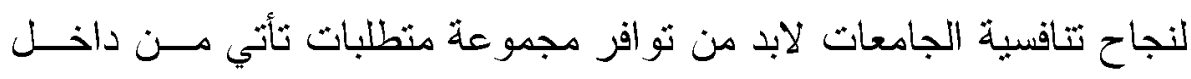

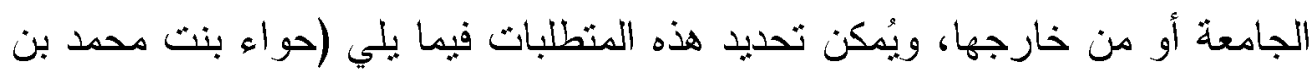

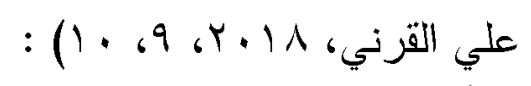
أولاً: المتطلبات الأخلية: و تتمثل في الآتي: 1. القبادة الجامعبة: بيطلب تحقيق الميزة التنافسية وجود قيادات جامعية قادرة على ولى

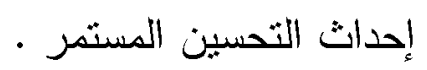

r. التوجه الإسنز اتيجي: تعنمد الجامعات على التوجهات الإسنراتيجية بحثناً عـن

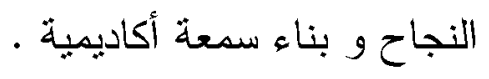

r. الكفاءات البثرية: الجامعات مؤسسات معرفية تحتاج إلى كفاءات مُؤهلة للقيـام بالعمل بكفاءة و فعالية .

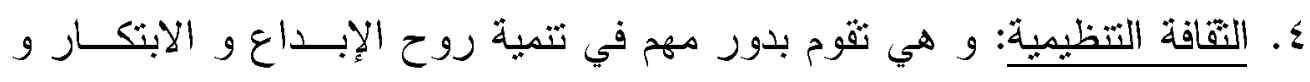

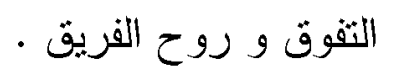

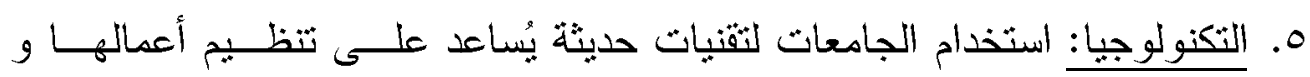

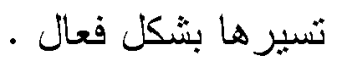
ج. الحو افز و المكافأت: يُحقق تحفيز العاملين تطور ملموس في الأداء الجـامي و يُحسن من استخدام الموارد .

V. البنية التحنية: إن نوفير البنية التحنية المناسبة في الجامعات -من مباني و معامل

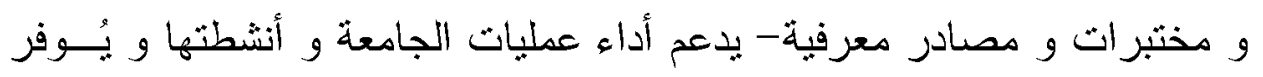

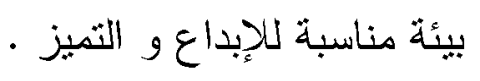




\section{ثانياً: المتطلبات الخارجية: و تثمثل في الآتي:}

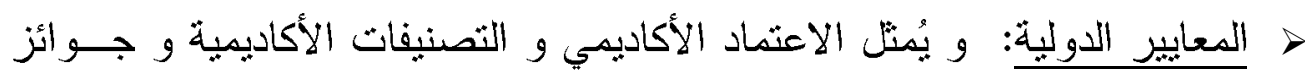
التميز، الصورة الأكثر وضوحاً للمعايير الدولية التي تتعامل معها جادعات اليوم، و تأني هذه المعايير استجابة لعولمة التعليم العالي.

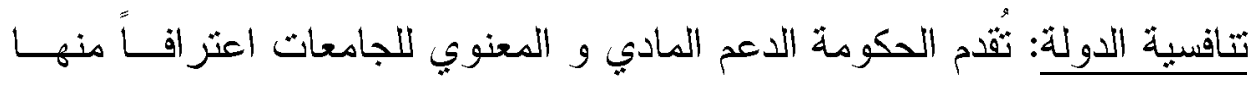
بالدور المحوري الذي تثوم به، و تدعم الحكومة تتافسية التعليم الجامعي عبـر

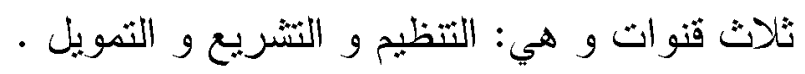

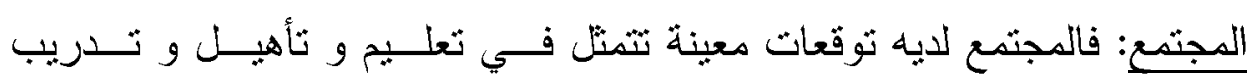
المو اطنين و استبعابهج في الجامعات .

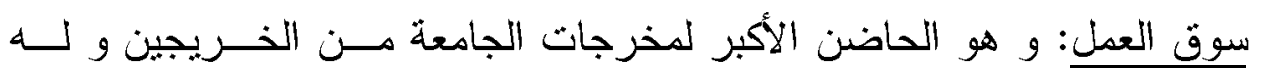
متطلبات لبستو عب هذه المخرجات. و هناك منطلبات أخرى لنحقيق قدرة تتافسية عالية للجامعة و أهمها (أحمــد محمــد

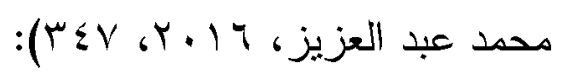

1. ثقديم منتجات و خدمات جامعية عاية الجودة و تتطبق عليها أحدث المواصــفات العالمية للتميز

r. استخدام تكنولوجيا منطورة لتحديث منظومة التعليم الجامعي من أجل زيادة كفاءة المخرجات الجامعية.

ب. الارثقاء بالموارد البشرية الجامعية على جميع المستويات الأكاديمية و الإداريــة من خلال الثدريب و التحفيز

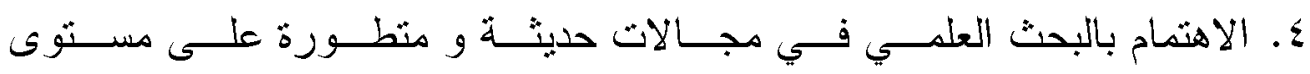

$$
\text { النانو تكنولوجي و الفمتونكنولوجي. }
$$

ه. در اسة المنطلبات العالمبة من الجامعات المصرية و ذلك من أجل فـنتح أســـواق

$$
\text { جديدة للمخرجات الجامعية . }
$$

ج. استخدام أدو ات إداربة حديثة منل الإدارة الإستر اتبجية و إدارة الأزمات و إدارة

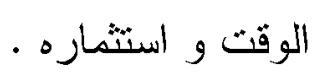




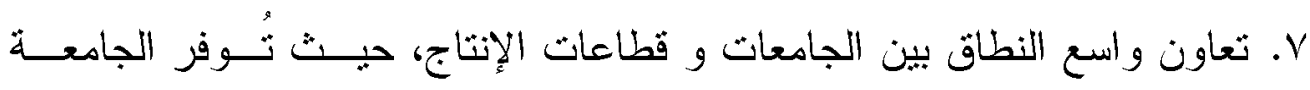

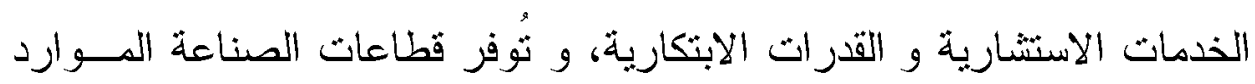
المادية اللازمة لتطبيق منت هذه الابتكار ات .

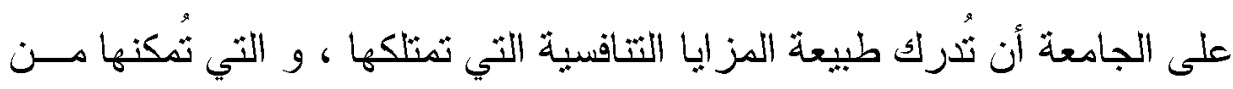
التصدي لحدة المنافسة و للحبازة على مركز تتافسي قوي في السوق، و هذا لا بكتمل

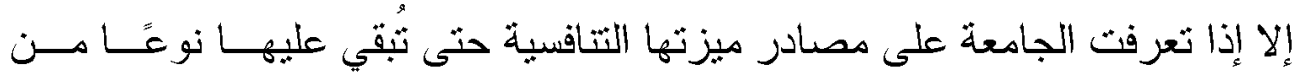

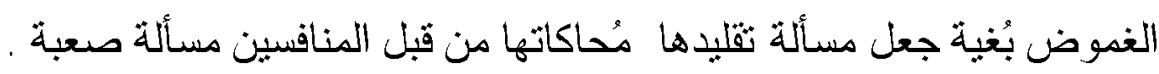

المحور الثاني : الاتجاهات العالمية المعاصرة في مجال تخليق الميزة التنافسية

البحامعية

تمهيد:

أصبحت التنافسية في التعليم العالي من القضابا المُلحة التي طرحت نفســها بعدد من الأشكال، كنتافس الطلاب للحصول على أفضل مسنوى من التعليم، و نتافس في لهن

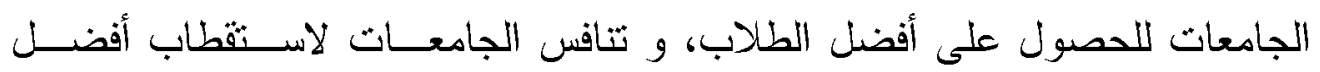
الأساتذة و أعضاء هيئة التشريس ، و تتافس الجامعات للحصول على موارد تمويـلـل

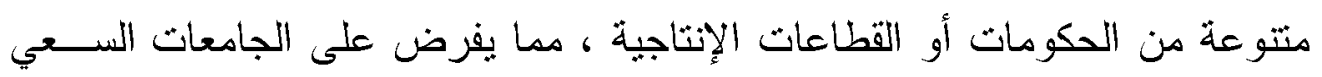

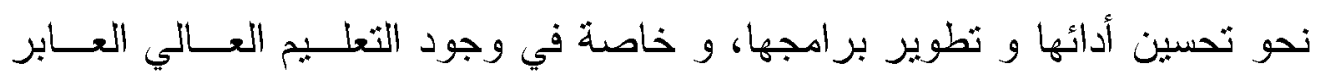
للحدود و القار ات. لذا يتتاول الباحث في هذا المحور بعض الإتجاهات العالميـــة المعاصــرة و بعض المداخل الأكاديمية و الإدارية و بعض التجارب الجامعية الرائدة فـي مجـــال

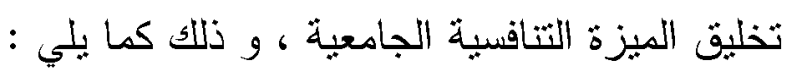

أولاً: الاتجاهات العالمية المعاصرة في مجال تخليق الميزة التنافسية الجامعية :

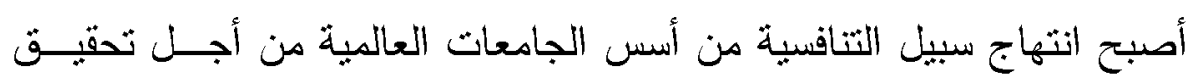

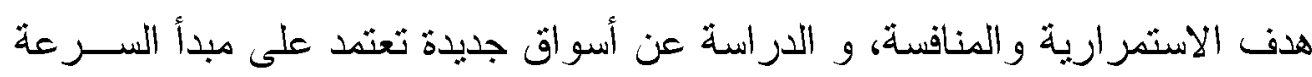

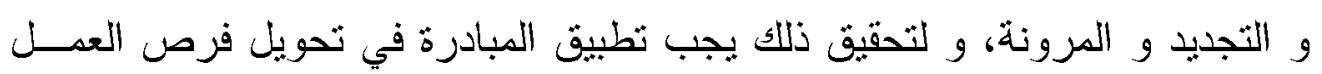




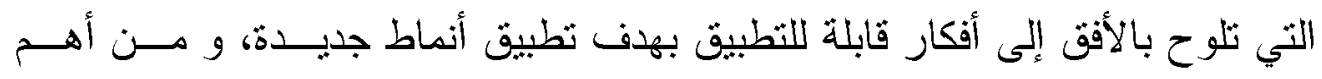

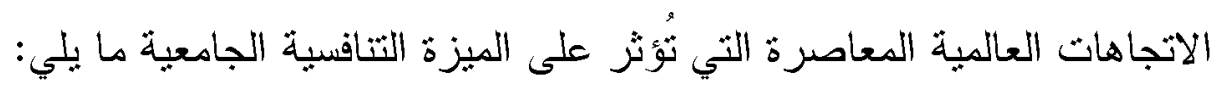

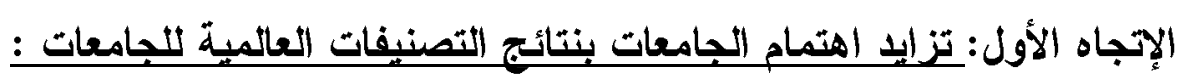

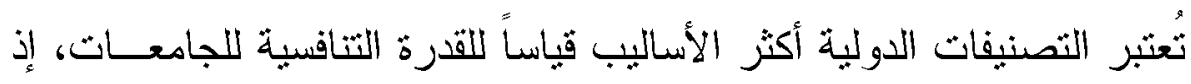

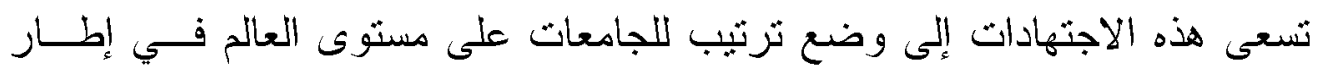

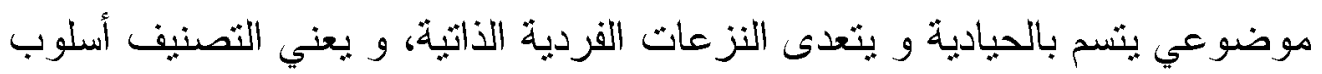

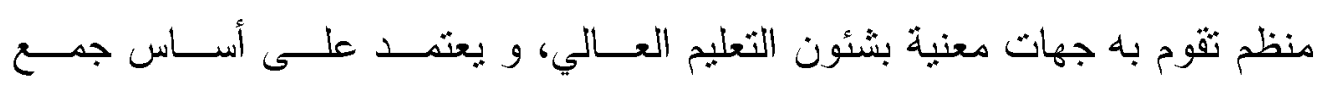

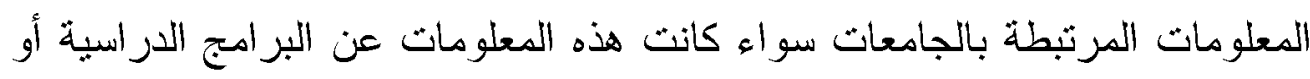

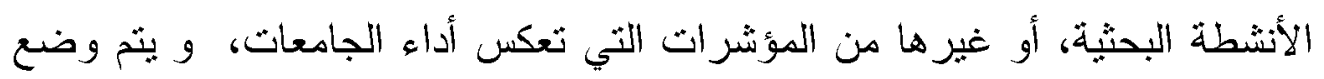

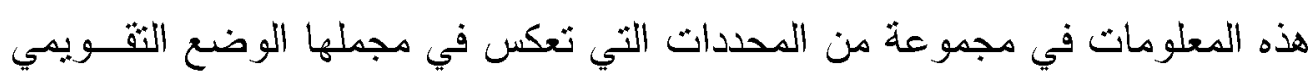

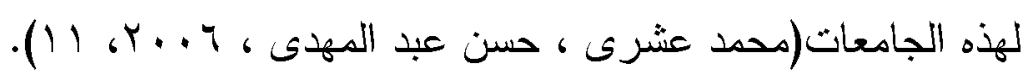
و ثسعى بعض المؤسسات العالمبة إلى وضع ثرتيب للجامعات على مسنوى

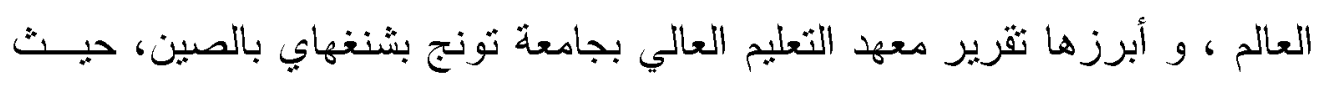

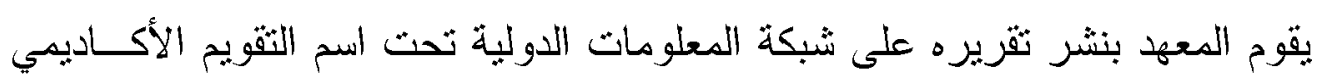

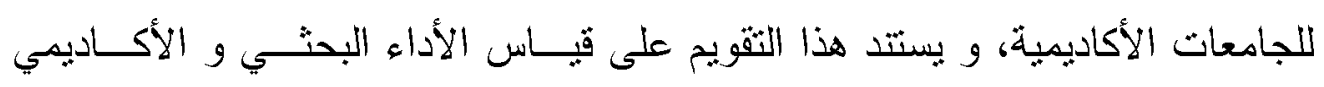

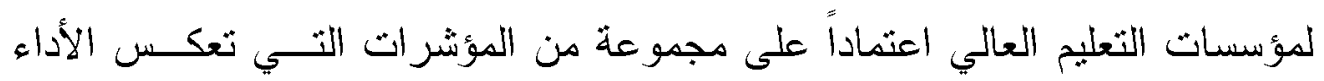

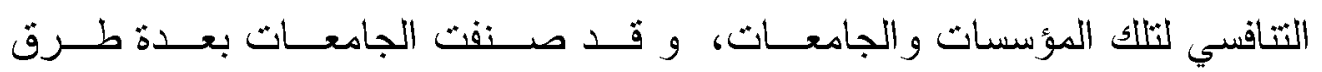

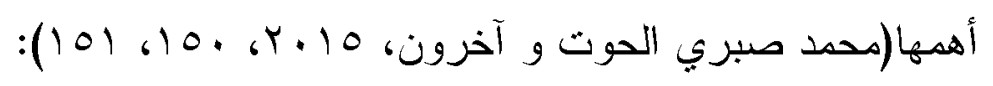

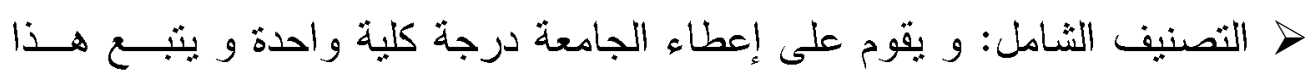

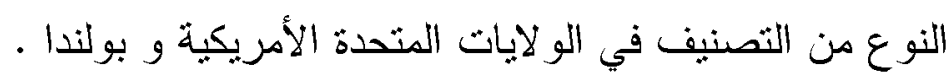

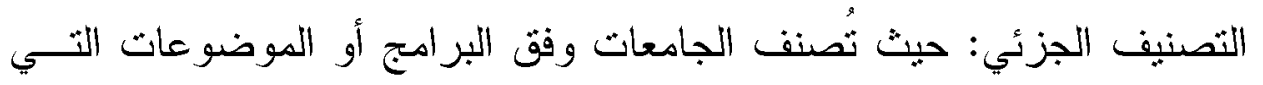

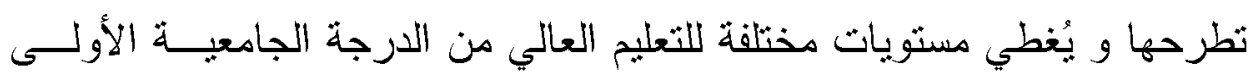

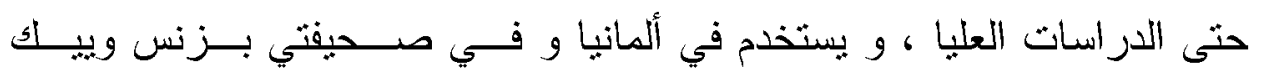

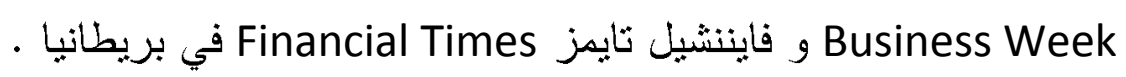


التصنيف المتتوع: و يشكل جميع الأنواع المتبعة للتصنيف و الني يوجد بينهـا

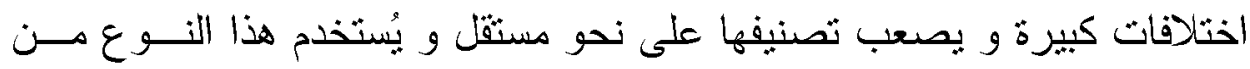

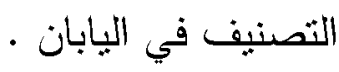

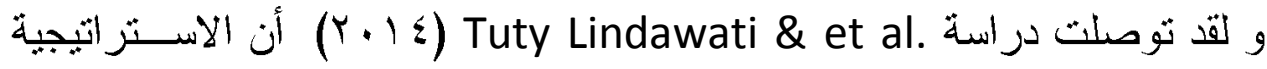
الني تعمل جامعة ويديا ماندالا الكاثوليكية widya Mandela Catholic -كجامعة تُحقق نتائج منميزة في التصنيفات العالمبة -على تقديمها هي اســنر اتيجية اســتباقية ثتز امن مع اثتين من البدائل الاستراتيجية المقترحة، و هي اختراق السوق وتطـــير المنتجات، و تمنلك الجامعة ميزة تنافسية للتغلب على نقاط الضعف الداخلية و كذلك الفرص الخارجية من حولها، و تعثمد الجامعة على رأس المال الفكري القائم على مئى

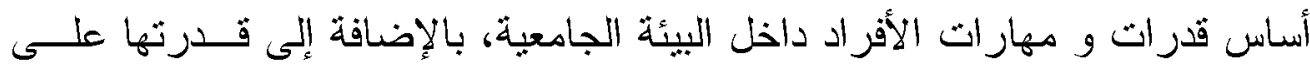

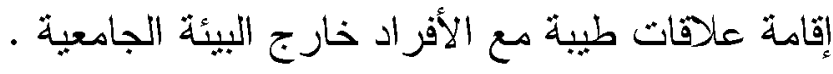

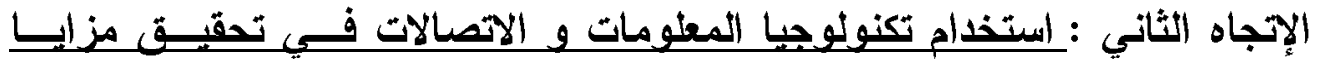
تنافسية للجامعة:

يُعتبر نطور نكنولوجي المعلومات و الاتصالات مدخلاً مهـــاً لتحقبـق الميـزة التنافسية الجامعية، و ذلك بفضل إسهامه في ابتكار منتجات جامعية جديدة، فهو رأس

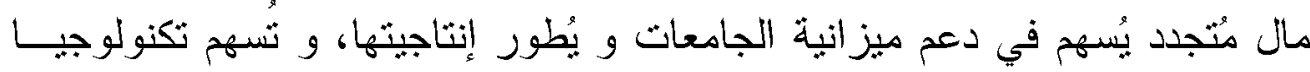
المعلومات و الاتصالات في ثقديم منتجات جامعية عالية الجودة، و تضمن الجامعـة بذللك تحقيق قيمة نتافسية عالية و مكانة سوقية كييرة (بلعلياء خديجـة و معدــوري

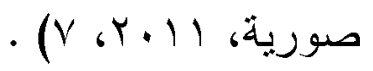

و لقد أدى تطور تكنولوجيا المعلومات إلى ظهور الإدارة الإلكترونبــة، و و

التي تعنمد على توظيف نكنولوجيا المعلومات في ثقديم منتجات و خدمات جامعيــة يستفيد منها المتعاملين مع الجامعة، و هي استراتيجية إدارية تُحقق خدمات أفضــلـل

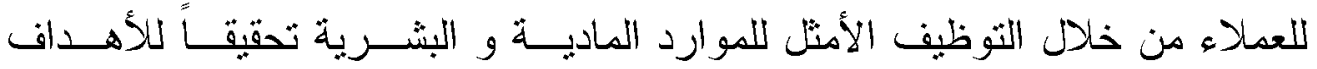
الجامعية و بالجودة المطلوبة، و إنجاز معظم معاملات الجامعة عبر شبكة الإنترنت 


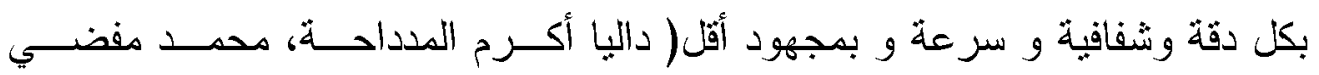
الكساسبة،

و تعتمد الجامعات على تطبيقات تكنولوجيا المعلومات و الاتصالات لمواجهة

التحديات المتلاحقة، وتوفير الوقت و الجهد و تحسين جودة الخـدمات الجامعيــة و الارتقاء بصورة الجامعة، و زيادة قاعدة المستفدين من خدماتها، و هي ثُمنل مصدراً

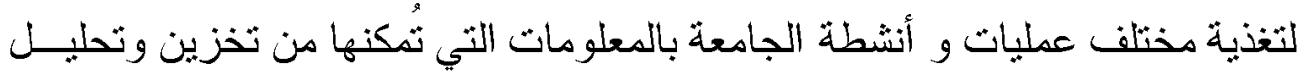

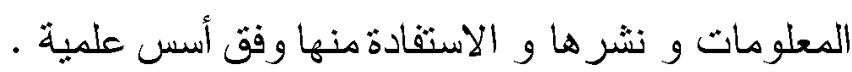

الإتجاه الثالث : استخدام مدخل إدارة الجودة الثاملة في تحقيت المبزة التنافسـيـية

\section{البحامعنة:}

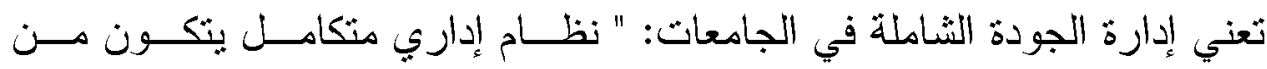

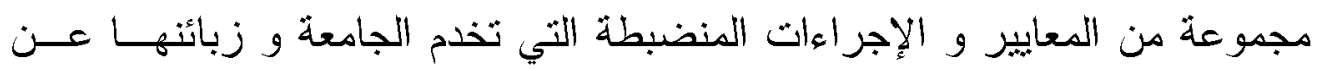
طريق التحسين المستمر في المنتجات و الخدمات الجامعية، و يثوقف نجاح الجامعة في تطوير قدرثها التتافسية على بناء سُمعة طيبة عن جودة منتجاتها و خـدماتها، و و

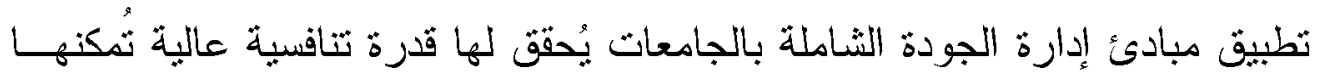
من مواجهة التحديات، و تحسين الإنتاجية، و خفض التكلفة، و إطلاق الابداع في كل

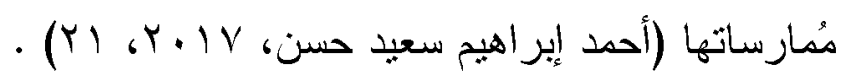
و لقد حدد David Garven خيير الجودة بجامعة هارفارد الأمريكية خمســة إهية عناصر أساسية يثوجب على المؤسسة اتباعها إذا ما اعنددت الجودة كأداة للتنافسية، و هي ( تحديد متطلبات الجودة من وجهة نظر العمبل، و النظر إلى الجودة على أنها

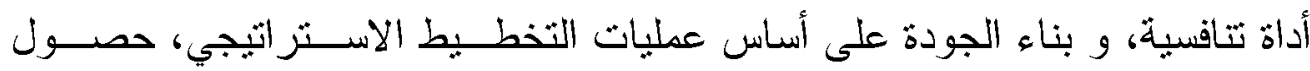
الجودة على الالنزام الكامل للجامعة، ربط الجودة مع الربحية مع النظر إلى النكلفة و

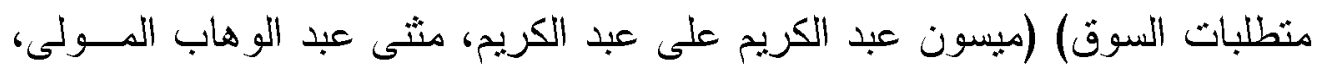
(r) r. Y. 19

و نسعى الجامعات في ظل بيئة شديدة التتافية إلى كسب ميزة ثتافسية عـن

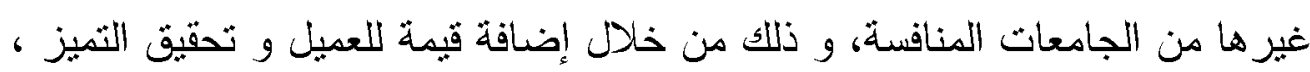


و ذلك عن طريق نطبيق مبادئ إدارة الجودة الثاملة، حيث يُؤدي ثطيقها دوراً مهماً في تحقيق ميزة تتافسية من خلال : ثدعيم الإمكانيات الماديــة، وتحفيــز الطاقــات البشرية، و تطوير تثقافة الجودة بالجامعة، و التركيز على الطلاب، والتركيز على جودة مخرجات العملية التعليمية بحيث ثتوافق مع احثياجات سوق العدـل ( حنــان

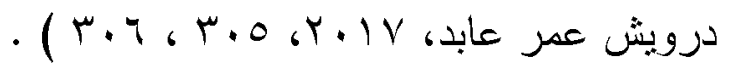

و من النجارب العالمبة الرائدة في نطبيق مبادئ إدارة الجودة الثـــاملة تجربــة الجامعة الجزائرية ، و الثي اعثمدت على مجموعة خطوات ثبدأ بتحديد الأهــداف و و الخطط و الإجراءات، و تحديد المؤشر ات التي تعمل على تحقيق مستوى معين مسن

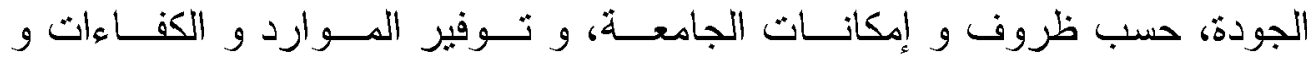
المعلومات و الهياكل التنظيمية الملائمة، و هذه الإستر اتيجية ساعدث الجامعسـة فـي تحسين ممارسات العمل و سلوكيات العاملين، و إدخال التغيرات اللززمة للتوافق مع المحيط الخارجي، و ثرشيد التكاليف، و تعظيم اسـتغلال الإمكانيـات المتاحسة، و

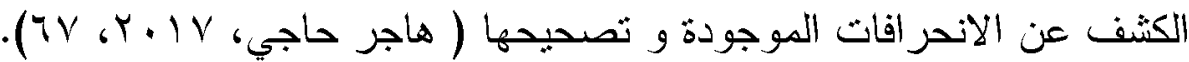
الإتجاه الر ابع : استخدام مدخل إدارة التمبز في تحقيق الميزة التنافسية الجامعية:

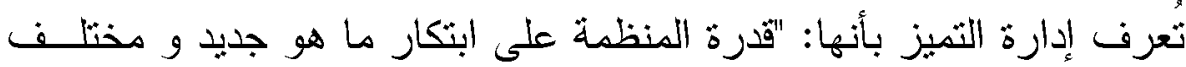

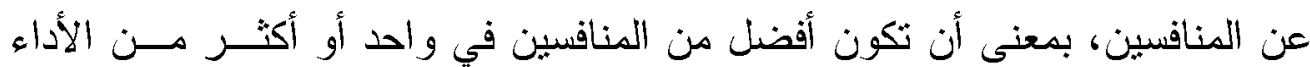

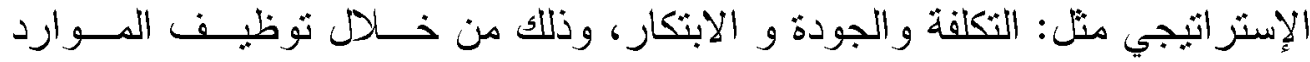

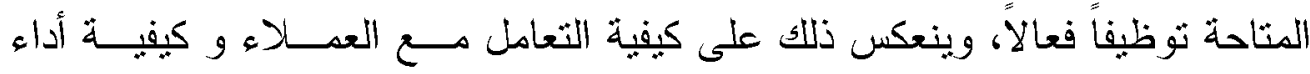
أنشطنها و عملياتها و إعداد استر اتيجياتها الإدارية و التنظيمية (سامي بــن جبــــان

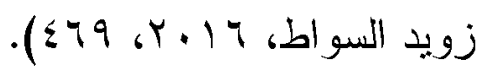

و تشتهدف إدارة التميز تحقيق مبزات تنافسية تضمن للجامعات تحقيق أعلى مستويات الأداء في جميع مكوناتها النتظيمية، بدءاً من رؤية الجامعة و رســالتها و

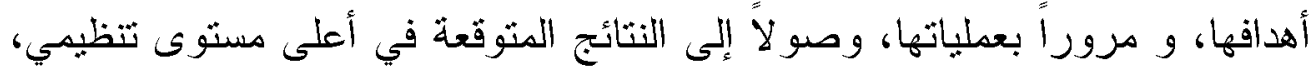

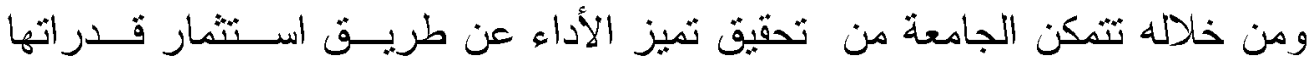

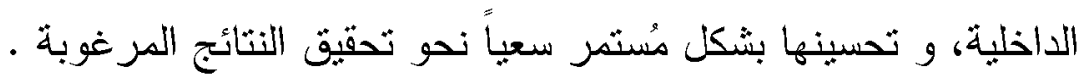


و لقد وضعت المؤسسة الأوروبية لإدارة الجودة نموذجاً معثمداً لتحقيق الثمبـز لكافة المؤسسات بغض النظر عن حجمها أو المجال الذي نعمل فيه، و يُعتبر النموذج أحد وسائل تحقيث الجودة و التميز المؤسسي المعتمدة عالمياً للارتقاء بمســتوى أداء

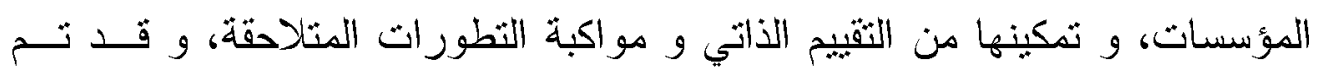

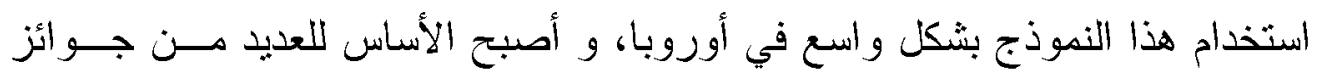

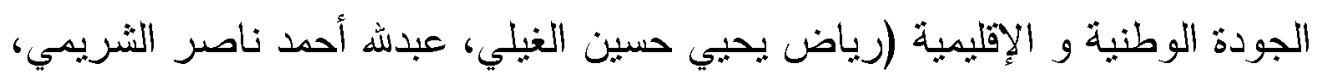
$\cdot\left(14 R_{6} t_{0}\right) 14$

و يُساعد نطبيق النموذج الأوربي للتميز المؤسسي في تعزيز قدرة الجامعسة

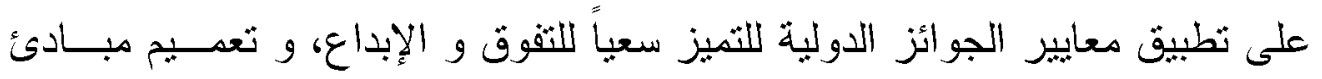

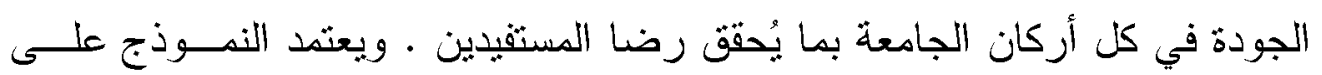

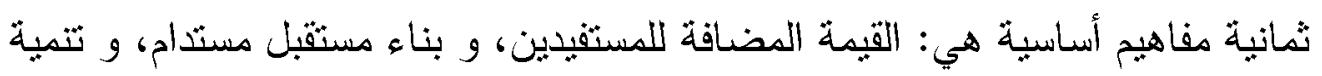

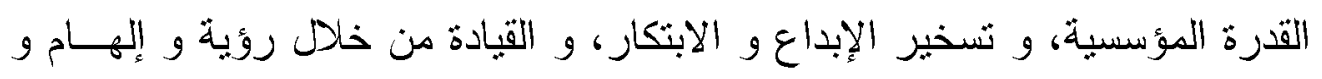

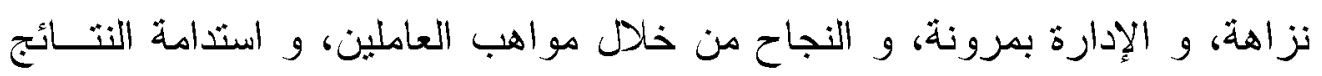

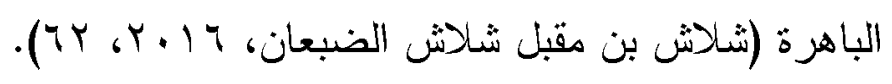

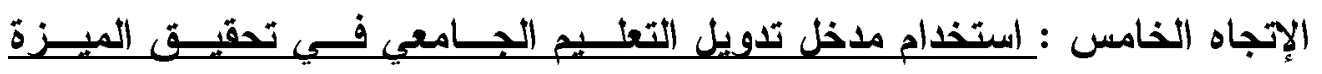
التنافسية:ة يعني تذويل التعليم الجامعي إضفاء البعد الدولي على كافة الأنثــــة الجامعيــة للارثقاء بكفاءة البر امج الأكاديمية بالجامعات، و تعزيز قدر اتها النتافسـبـة محليـاً و

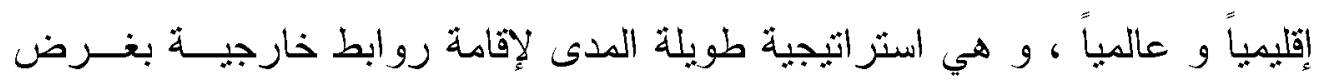
تفعيل الحر الك الدولي للطلاب، و التنمية المهنية لهيئة التدريس، و التجديد في المناهج و تحديثها، و دعم المثروعات البحثية بين الجامعات . و هنالك مجموعة من المو اصفات التي تحقق الميزة التتافسية للجامعة من خــلال تذويل برامجها التعليمية و البحثية ، وهي (محد إبراهيم عبد العزيز خاطر، 10 ـب، $:($ Yo. 
تبادل الأساتذة و الطلاب لتبادل الخبرات في مختلف المجالات التعليمبة و البحثية و المجثمعية .

إضفاء الطابع الدولي على البرامج الدراسية و العمل التعليمي بمنظور عالمي .

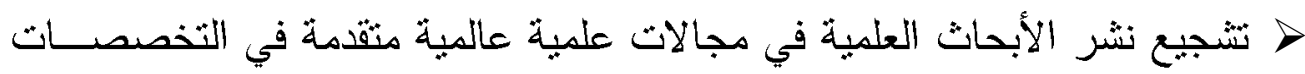

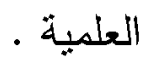

> دعم المبادرات المحلية و الإقليمية و الدولية في المشروعات الجديدة و الســي

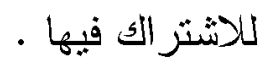
عقد ندوات و ورش عمل و مؤثمرات مشتركة لتبادل الخبرات محلياً و إقليمياً و

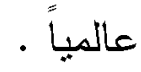
تعظيم الاستفادة دن الجامعات الأجنبية العاملة، و اتخاذها وسيلة لجذب العقول و

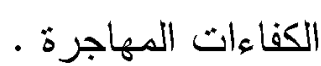
كما تُعد جامعة موناش الأسثر الية من الجامعات الرائدة في تطبيق إســر اتيجيات

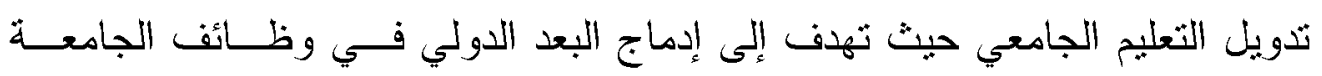

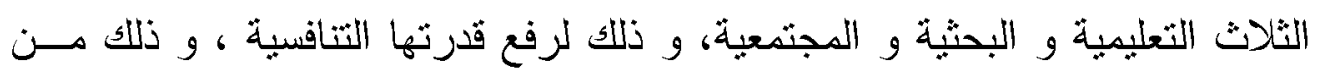
خلال .Mertova, Patricia, Green, Wendy , 2010, 101, 102): > منح درجات علمية ذات بعد دولي: مثل درجــة البكلوريـــوس فــي الدراســات

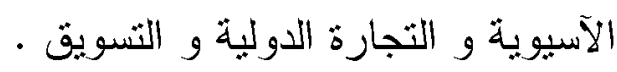

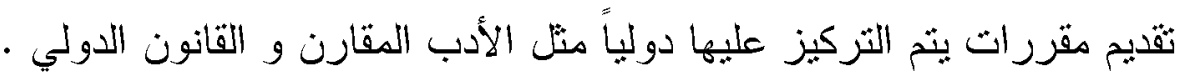

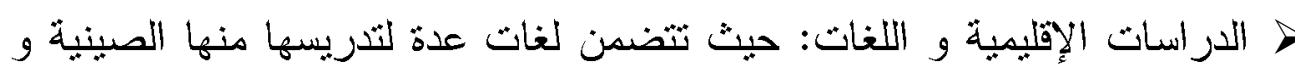
البابانية و الكورية . تضمين بر امج تدريب أعضاء هيئة التذريس موضوعات دولية و توفير التمويل اللازم للمثرو عات المبنكرة . إنشاء الجامعة لشركة دوناش الدولية: و ذلك لتقديم الخدمات التالية : (التســويث

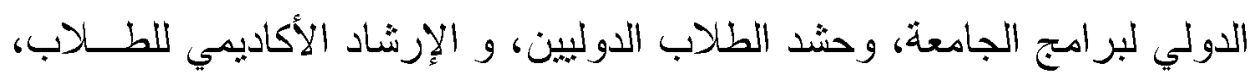

$$
\text { و الاستشارات الدولية . }
$$


تُقلم الجامعة مواد ثسويقية و معلوماتية شاملة و جذابة: إذ يصدر عن الجامعسـة

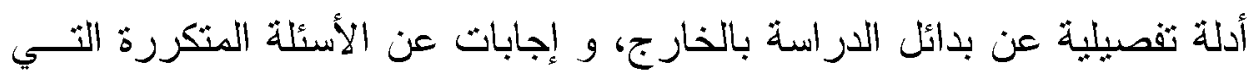
بسألها الطلاب مابه

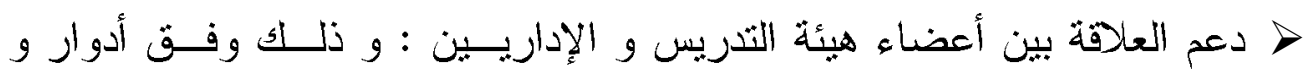

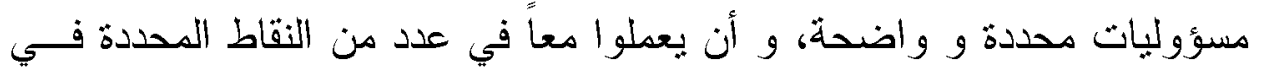
عملية اختيار و إرشاد و ثقويم الطلاب المشاركين . إ إنثاء الجامعة لمركز موناش للبحث في الثربية الدولية : و ذلك بهدف الاستفادة

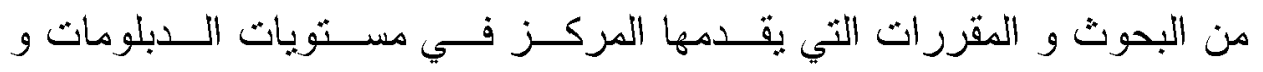
الماجستير في الثربية الدولية و الثربية المقارنة .

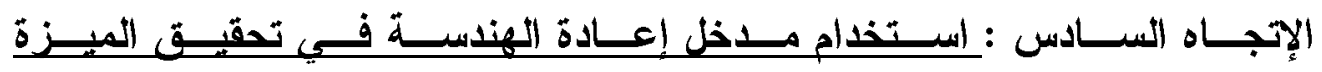
Reengineering Approach التنافسبة الانسية يعني مدخل إعادة هندسة العمليات: "إعادة تتظيم العمليات بشكل يُؤدي إلـى

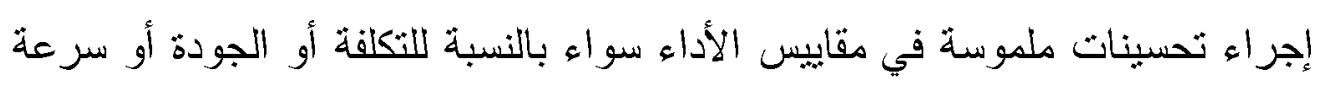

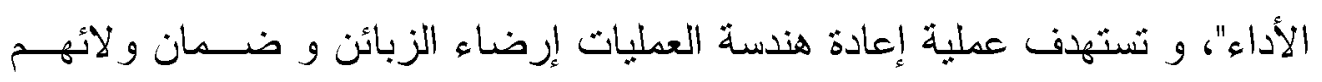

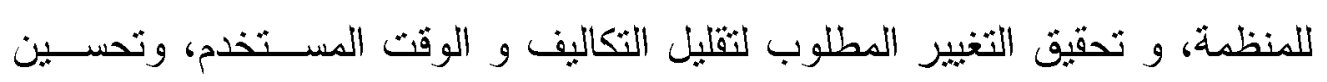

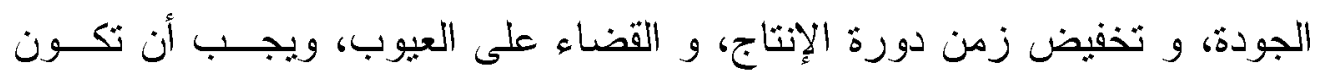

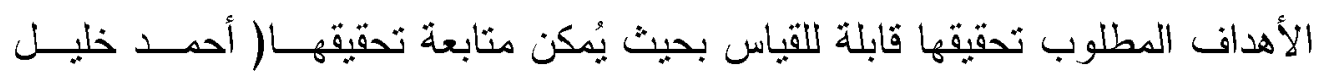

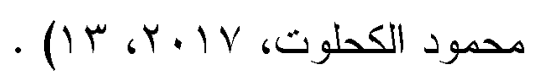

و نعني هندسة العمليات الجامعية: عملية نطوير جذريــة ثمـس العمليـات

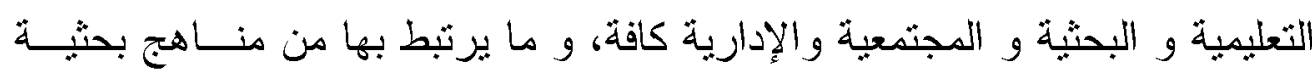

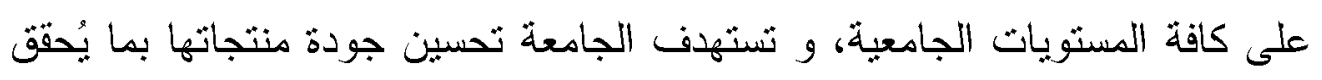

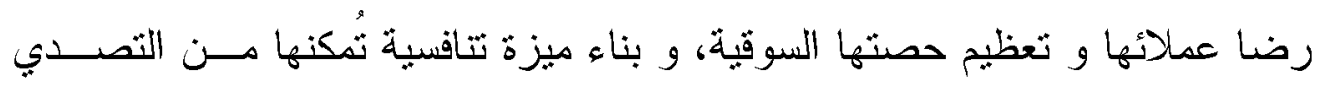

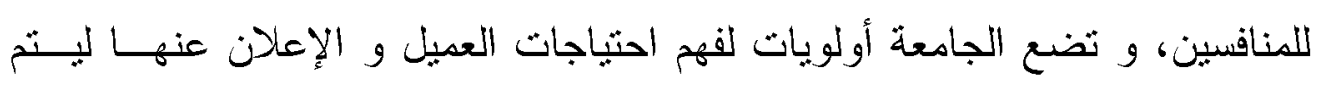

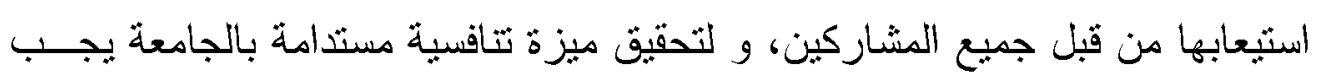


متطلبات تطوير الميزة التتافسية لجامعة أسوان في ضوء الاتجاهات العالمية المعاصرة

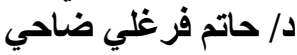

تو افر موارد مثميزة لديها لكي تشنطيع المنافسة بها و هذه الموارد تثميز بالنــدرة و

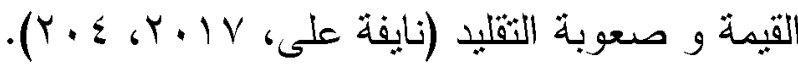

و تثبنى الجامعة الإسلامية بغزة مشروع ضخم لإعــادة هندســة العمليــات

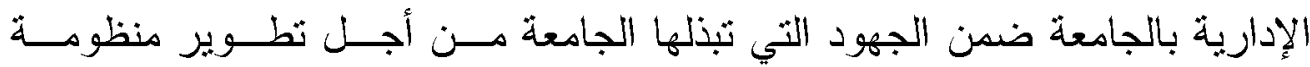

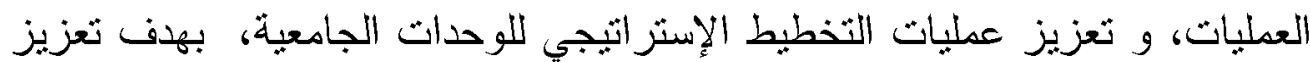
الدور الأكاديمي للجامعة، و ثرنكز فكرة المشروع على ثنسيط الإجراءات الإداريــة

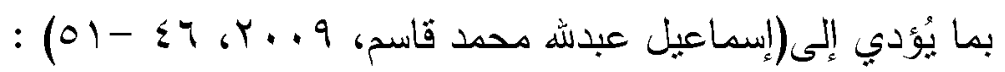

> تحسين مستوى الخدمات المقدمة للمستفيدين و زيادة مستوى الرضا لديهم. > توفير الجهد و الوقت و المال المخصص لتتفيذ العمليات في الأقسام الإدارية . تكوين و بناء دليل إجراءات و عمليات لكل وحدة و قسم إداري . > تعزيز ثقافة الجودة الإدارية الثناملة في مختلف الأقسام و الوحدات الإدارية . > تعديل بعض بنود النظام الإداري و كذلك الهياكل التنظيمية و الوصف الوظيفي .

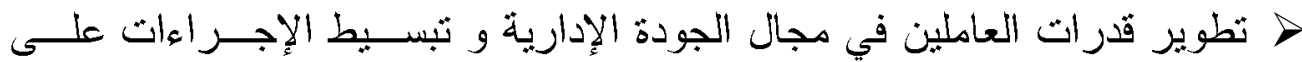

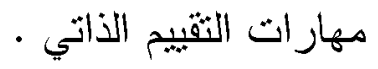

> عمل أدلة جديدة لتوثيق الإجر اءات و العمليات الإدارية بعد إعادة هندستها .

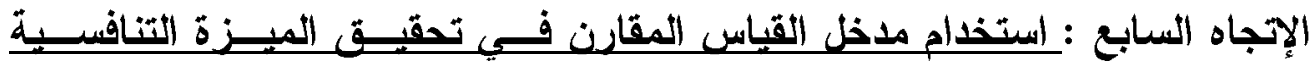

\section{Benchmarking الجحامعية إنية}

و هو من الأساليب الحديثة الثي تشتخدمها المنظمات في مقارنة أداء عملياتها و منتجاتها بأفضل منافسيها لمعرفة نقاط قوتها و ضعفها و البحث عن مز ابا نتافسية.

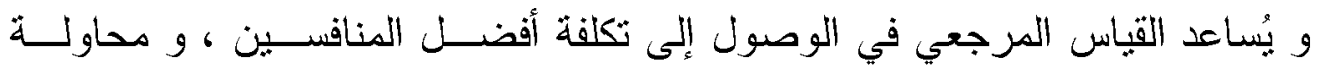
تحسينها للوصول إلى مستويات أفضل منها، و البحث عن مناطق تخفـبض تبض تكلفــة

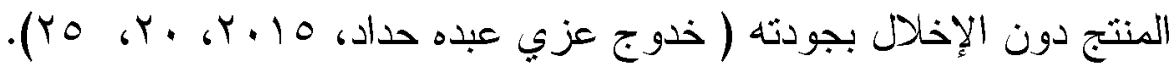
و الفكرة الأساسية التي يعنمد عليها هذا المقياس هي: الاستفادة مــن أفكــار الآخرين، و محاولة نطييق طرق مماثلة للحصول على ميزة تتافسية، و لا ينم ثقليد

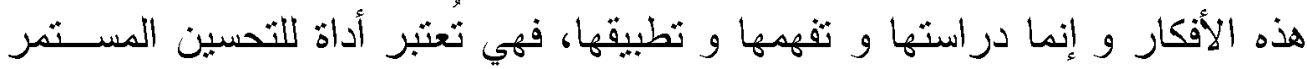


لأداء المنظمات، و هي الأسلوب المفضل لاى العديد من المؤسسات العالمية و أهمها Ford, Toyota, General Motors, Motorola, Xorex

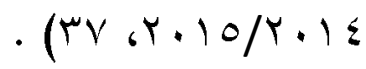

وتثمثل أنشطة القباس المقارن بالجامعات فيما يليل(أماني نصر على عواجي،

$:(07.60096 \% \cdot 19$

مر اجعة دورية للمركز التتافسي للجامعة و البحث عن محسـاور جديــدة للتمبـز

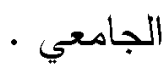

مر اجعة تصميم المنتجات و الخدمات الجامعية بصورة دورية مقارنة بتصــاميم

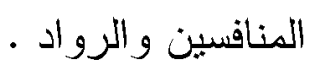

مر اجعة تصميم المنتجاث والخدمات الجامعية بحيث تصل لثرائح جديـدة مسن

العملاء

> مر اجعة تصميم أساليب التدريس لتنتاسب مع نطور مواصفات الخريجين و كفاءة

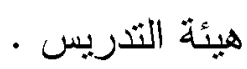

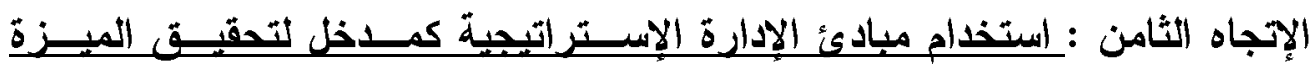
التنافسية الجامعية:

تشتهدف الإدارة الإستر اتيجية صياغة الإسنتر اتيجيات التتافسية، و ربــط البيئـة

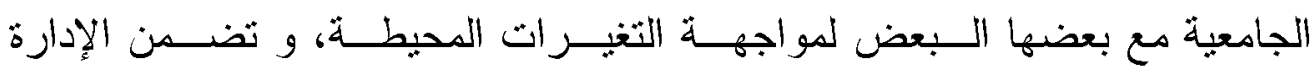
الإستراتيجية تنمية القدرة التتافسية للجامعة في ظل منغيرات البيئة النتافسية، و لكي تسنطيع الجامعات مو اكبة التحديات العالمية و دعم قدرثها التنافسية في ضوء مدخل

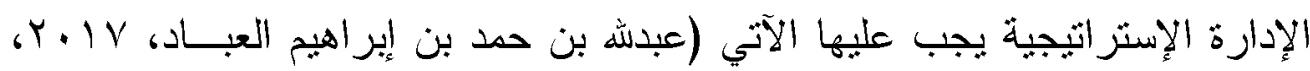
$:(r)$

وضنع استر اتيجيات لقياس الحاجات و الطلبات الحالية و المستقبلية .

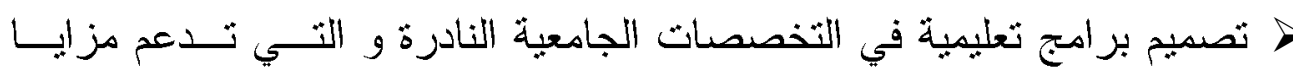
تتافسية مينم 
متطلبات تطوير الميزة التتافسية لجامعة أسوان في ضوء الاتجاهات العالمية المعاصرة

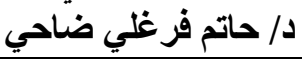

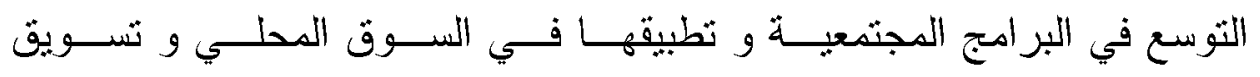

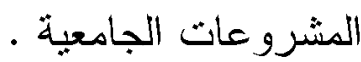

تطبيق أسلوب التخصصات الرئبسية و القرعية بين الكليات وفق نظام الساعات المعتمدة . Dا إنثاء مركز لبحوث الثشويق الجامعي و ثقسيم السوق المحلي و الــدولي إلـى قطاعات .

الإتجاه التاسع : الثر اكة البحثية بين الجامعات و المؤسسات الإتتاجية: تعني الثراكة البحثية بين الجامعات و بين المؤسســات الإنتاجيــة علاقــات

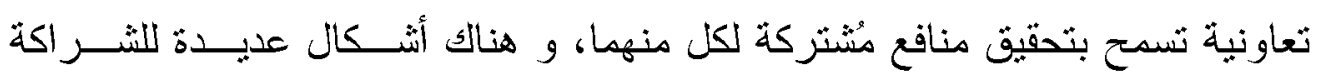

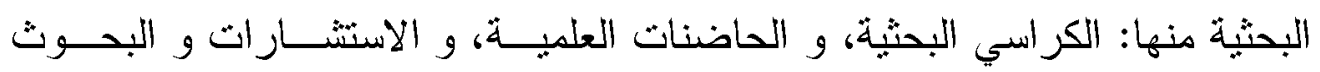
الداعمة ـ و تعني الميزة التتافسية في هذا المجال قدرة الجامعة على تحقيق التميـز

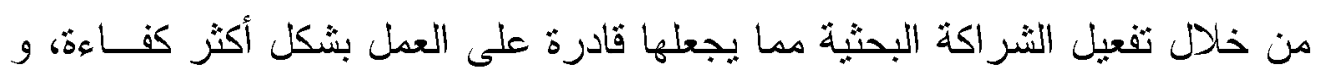

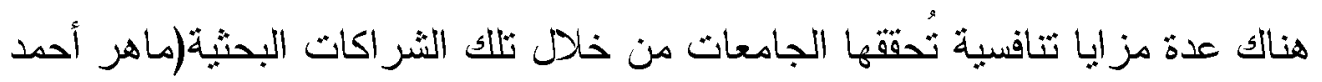

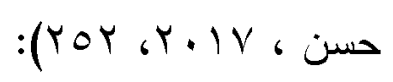
> زيادة قدرة الجامعة على إنتاج المعرفة الثقنية المنطورة و الإفادة منها في نطوير - المجنمع > ربط البحوث النطبيقية الجامعية بالمثكلات المختلفة التي ثواجه المجثمع المحبط. > الحصول على الإستشارات الفنية و البحثية للجامعات في معالجة مشكلات العمل باتل

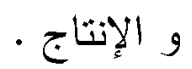

> تحقيق أعلى معدلات النشر العلمي للبحوث العلمية في المجلات العالمية وصولاً للتنتافسية. > تعزيز المركز النتافسي للجامعة و تحسين أداء أعضاء هيئة التذريس و دفعهـ نحو التجديد . نمريد

توظيف المو اهب من الأوساط الجامعية سو اء على مستوى المرحلـــة الجامعيــة الأولى و الدر اسات العليا 
متطلبات تطوير الميزة التتافسية لجامعة أسوان في ضوء الاتجاهات العالمية المعاصرة

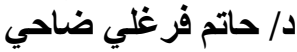

الإرثقاء بسمعة الجامعة خلال الأوساط العلمية و تطوير البحوث في إطار نظـــ الابتكار الوطنية.

Cambridge (MIT) تعتبر تجربة معهد ماساتشوستس للتكنولوجيا بكامبردج من نماذج الثراكة البحثية بين الجامعات و المؤسسات الإنتاجية، و هو يُمثل نجربة منميزة في مجال نطوير تدفق المعرفة بين الجامعة و المؤسسات الإنتاجية، مما يُسـهل نقل التكنولوجيا و رفع القدرة التنافسية للمعهد، و هذا من خلال شر اكة المعهد مــع شبكة واسعة الثركات الإنتاجية بهدف إبراز مجنمعات نكامل المعرفــة (KICS)، و و تشتهدف تعزيز أنشطة نبادل المعرفة، مثل: مجال نطوير القدرة النتافسية، و مبادرة

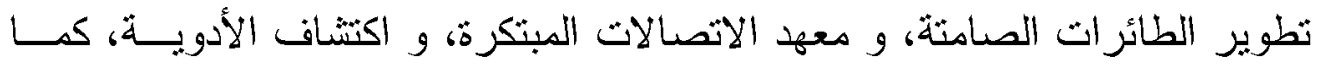
ظهر مجتمع جديد للمعرفة يقوم على مشروعات بحثية منطورة حول مجال الرعاية الصحية (مجال الموارد الحيوية الجديدة لبدائل العظام، و ثطويز منصات إنتاج جديدة لأدوية مرض السل)، و القيام بدراسات جديدة في مجال ريادة الأعمال ساهمت فـي

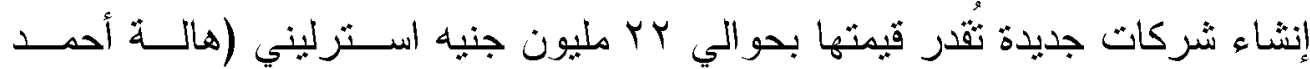

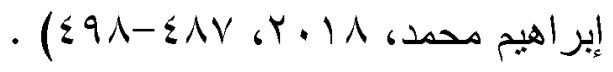

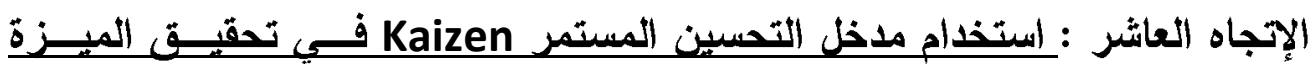
التنافسية الجامعية: إن نشأة منهج كايزن للتحسين المستمر كانت في اليابان في الخمسينات من القرن

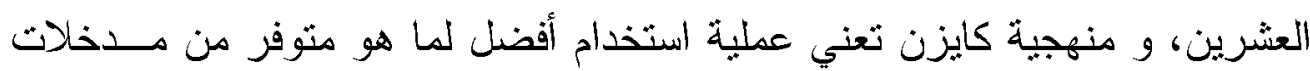
(معدات و أماكن و أفر اد و أساليب عمل و ثقنيات) و محاولة التحسين خطوة خطوة

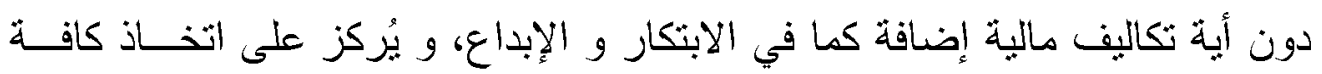

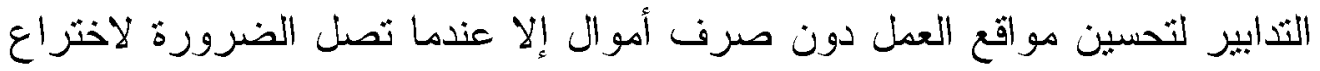
تقنية جديدة، و بعد استنفاد كافة الإمكانات لاستغلال ما هو مثو افر (مزنة المارديني ،

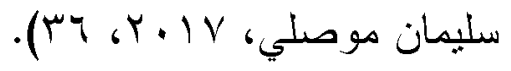
و ينم وفق هذا الددخل نطوير الأداء حسب الآتي: التطوير المستمر مسؤولية كل

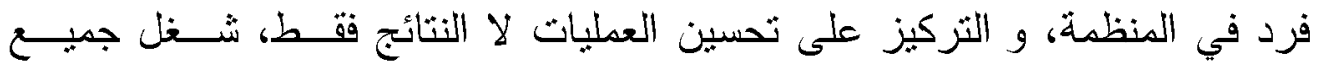


المجالات الإنتاجية، و لا بنتم النطوير إلا إذا ثم الاعثر اف بأن هنــاك مشــكلات، و

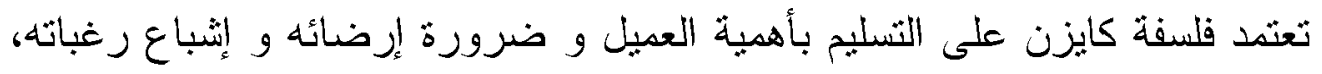
و التطوير عملية مستمرة و لابد من إعطائها الوقت اللازم (شلاش بن مقبل شــلاش

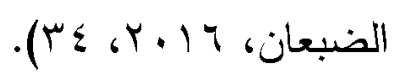

و يُعنبر ثو افر مناخ الإبداع من الثروط الأساسية لنجاح أنشطة التحسين المستمر في الجامعة و هو يتطلب نو افر العديد من المقومات منها: دعـــ الإدارة الجامعيــة لأنثطة الإبداع، و تعزيز التفاعل بين الجامعة و البيئة الخارجية، و تدعيم نشاطات

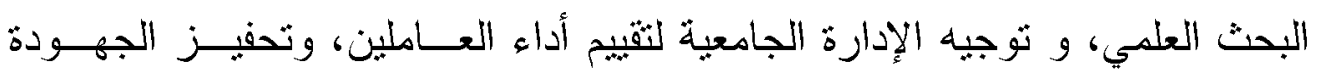
المبدعة و الأفكار التجديدية، و تشجيع روح الاسثقلالية، و التدريب على ثوليد الأفكار الإبداعية المبية

الإتجاه الحادي عشر : الكر اسي البحثية مدخل لتعزيز الميزة التتافسبة الجامعية: تعني الكراسي البحثية برامج جامعية تشمل الصورة البحثية و الأكاديمبة ثقوم

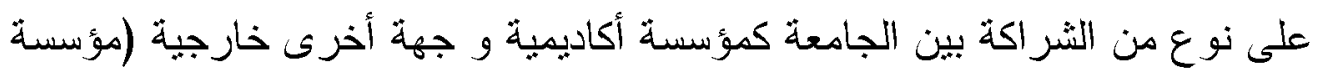

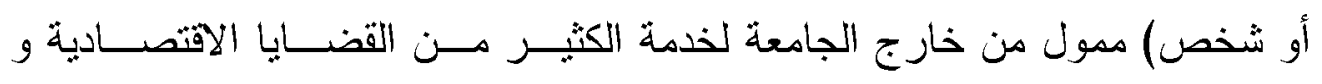

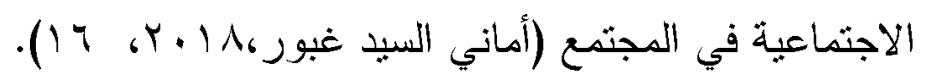

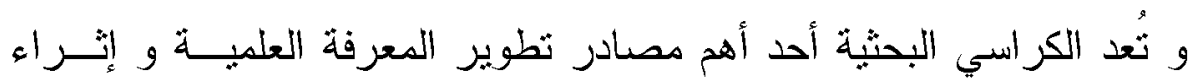

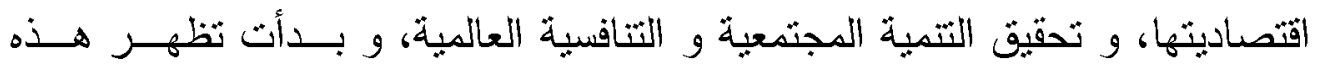

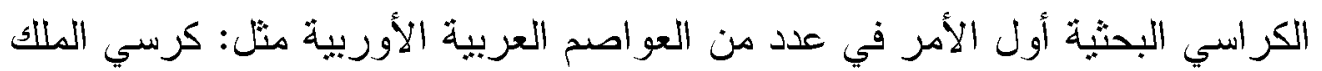

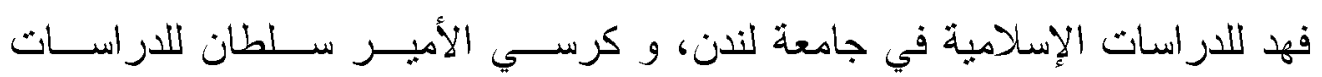

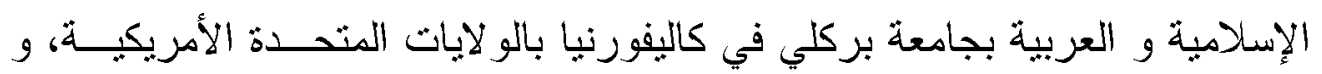

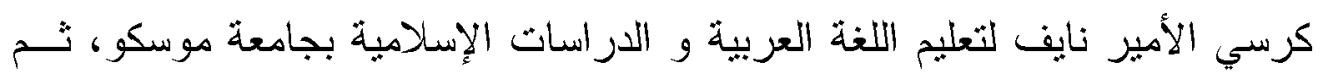

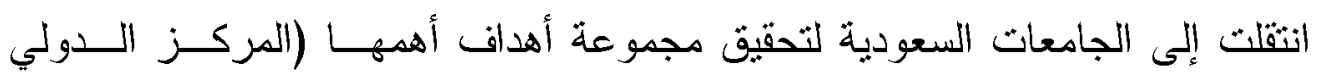

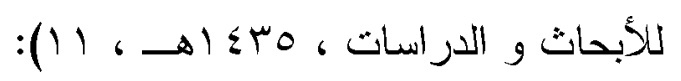

> تحقيق رغبات المجتمع السعودي و نطبيق بعض البرامج البحثية في الجامعـات السعودية . لمئية 
> اسثقطاب الكفاءات العلمية و تشجيع طلاب الدراسات العليا على المشاركة فـي

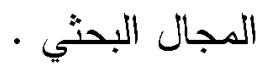
الإفادة من أصحاب الخبرات العلمية و تسخبر خبراتهم لتطوير الرصيد المعرفي

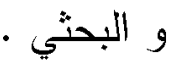

> دعم و تشجيع و ثطوير أبحاث المجالات النخصصية موضع اهنمام الكرسي • > دعم موقع الجامعات السعودية في خارطة الثميز البحثي و إثراء المعرفة العلمية.

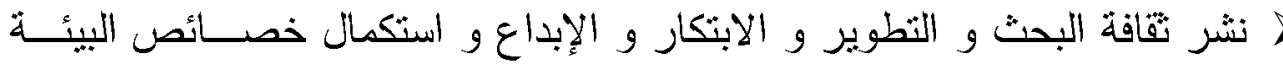
البحثية المنطورة . و قد اسنطاعث الجامعات السعودية الني حظبث بدعم مالي و معني حكومي كيير إلى إيجاد العديد من الكراسي البحثية من أجل ثقديم إثراء بحثي متميز و إنتاج بحوث

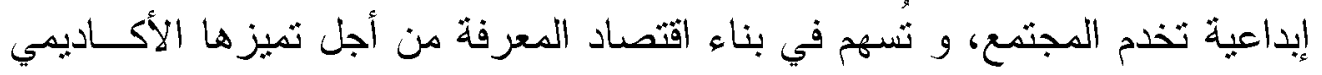
لتحقيق مزايا ثتافسية مستديمة، و الحصول على اعثراف عالمي بجودة مخرجاتهـا

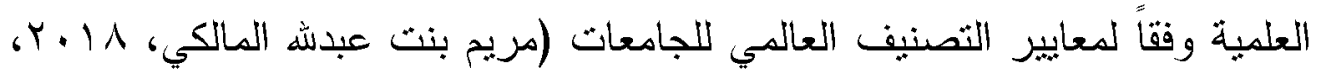
.$(V \vee Y$ الإتجاه الثاني عثر : مو ائمة مخرجات الجامعة و متطلبات ســوق العمـل كمـــل لتعزيز مزاياها التنافسبة: أصبحت الجامعات مطالبة بالإعداد لسوق العمل من خلال إعادة تأهيل الخريجين عبر دورات تكوينية لنسهيل ولوجهم لسوق العمل، و تشجيع الطلاب علـى العهـلـل

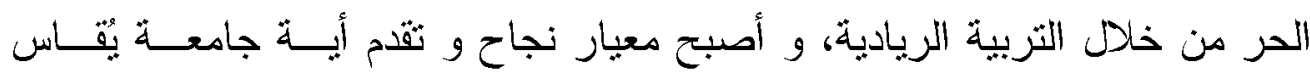

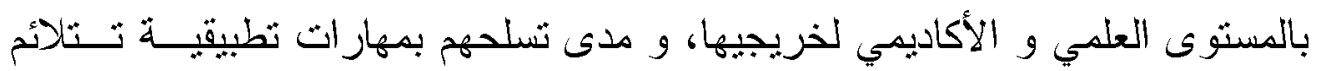

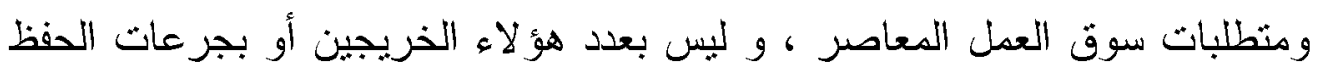

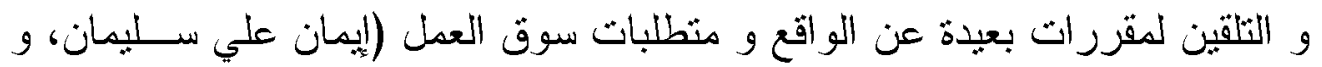

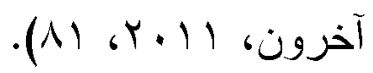

و تعني الميزة التتافسية مجموع ما يمنلكه الخريج من مهار ات فنية و شخصية و

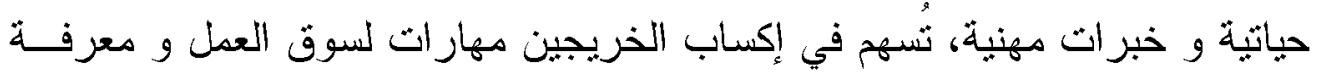




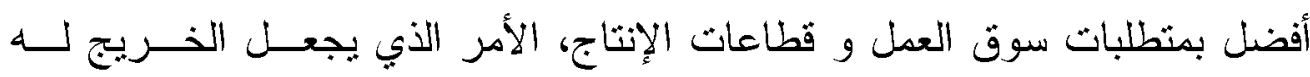
الأفضلية على المنافسين بما بُمكنه من الحصول على الفرص و الوظائف المطروحة

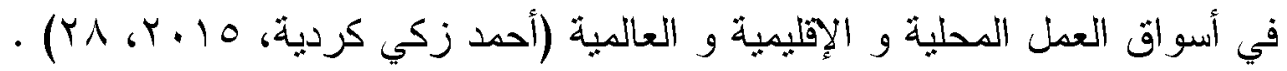
و حتى تثمن الجامعات من تحقيق مز ايا تنافسية في مجال الوفــاء باحتياجـات

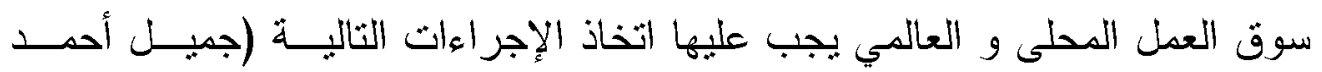

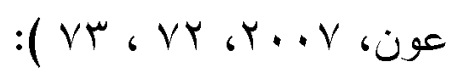
> اتخاذ آليات لتحسين نظام التعليم الجامعي لتمكين سوق العــل مــن اسـتيعاب الخريجين > تطوير البرامج التعليمية و تعميم دراسة الحاسوب و اللغات فـي الجامعسات، و تطويرها و تحديثها > تحسين التجهيزات التعليمبة و نطوير أساليب التدريس بما يواكب الثقدم العلمي و التكنولوجي.

> اعتماد سياسة قبول تكفل رفد الجامعات بمدخلات قادرة على التحصبل العلهـي

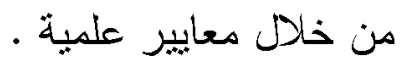
> إنشاء آليات فعالة يُمكن أن تُوفر فرصاً ملائمة بين طالب العمل و فرص العمل الموجودة و المحتملة . الماه. > إعداد مخرجات جامعية مؤهلة و ذات كفاءة لتنافس في إطار سوق العمل الــذي

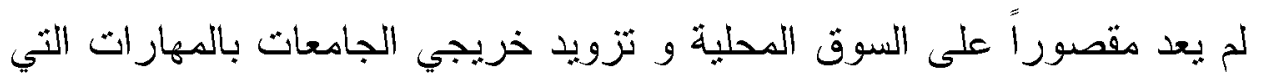

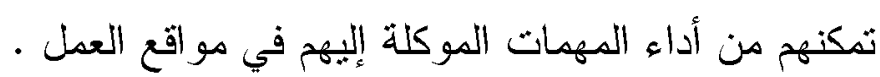

الإتجاه الثالث عشر : استخدام مدخل ستة سيجما (Six Sigma) في تحقبــق المبـزة

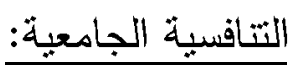

اتجهت العديد من جامعات العالم و منها الجامعات الأمريكية نحو دمج منهجية في عمليات التخطيط الإستر اتيجي لمستقبل الجامعات كمدخل لتقبـــيم

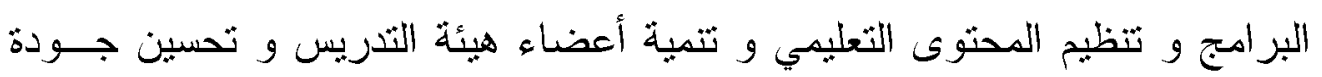
العمليات الأكاديمية بالجامعة، و دمج ثلاك المنهجية في الخطط الإستر اتيجية للجامعة 
بُساعد على تطوير التعليم الجامعي كماً و كيفاً عن طريق منهجيـــة تنفــذها الفــرق المنوط بها في إستر اتيجية الجامعة انطلاقاً من رؤيثها و رسالتها و ثلبية منطلبـات عملائها و حاجات سوق العمل و ذلك من خلال خطة عمل تحول تلأك الإستراتيجية

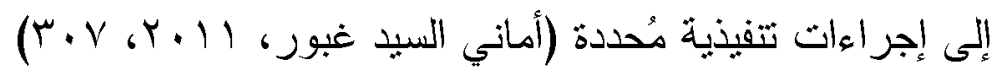

و من أهم فوائد نطبيق أسلوب سيجما ستة في مجال تحقيق الميزة التتافسية الجامعية: نطوير فريق عمل منعدد المهام بالجامعة ، و رفع معنويات العـاملين، و و التقليل من العمليات الإدارية غبر المجدية، و ثقليل نكاليف العمليات الجامعيـة، و نشر الوعي حول أدوات حل المشكلات ، و زيادة معايير ثبات الخدمات الجامعيـة، اتخاذ القرار ات الجامعية في ضوء الييانات و المعلومات، و رفع مســثوى انتاجيــة الجامعة، و تطوير مهار ات القيادات الجامعية ، و تقديم الجامعة لأفضــل الخــدمات

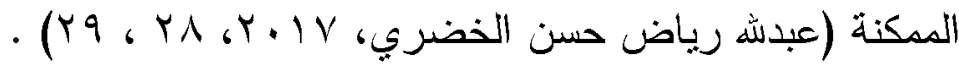
الاتجاه الرابع عشر: استخدام مدخل إدارة المعرفة فــي مجــال تحقبـت الميـزة التنافسية الجامعية:

تستهدف إدارة المعرفة بالجامعة تحقيق الأهداف التالبة: تبسـبــ العملبـات الجامعية، و خفض التكاليف عن طريق التخلص من الإجر اءات المطولة ، و تحسين خدمة العملاء، و ثبني فكرة الإبداع عن طريق تشجيع مبدأ تدفق الأفكار بحريسة، و و زيادة العائد المالي عن طريق نسويق الخدمات و المنتجات بفعالبة أكبر، وتحســين

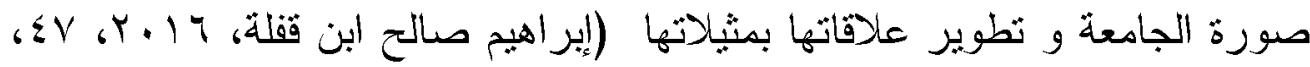

و تطبيق إدارة المعرفة في الجامعات لابد أن بقود إلى تحقيق مزايا نتافسية من خلال تمكين الجامعة من تطبيق أنسب للاستر اتيجية التتافسية لها، بالاعتماد على

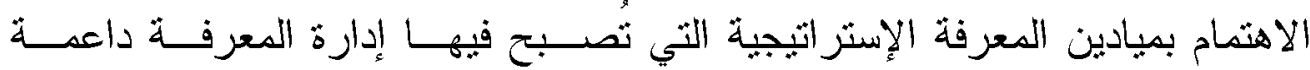
للاسنتر اتيجية التتافسية للجامعة . لهية

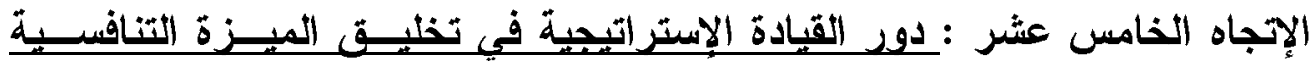
الجامعية: 
تعني القيادة الإسثر اتيجية بالجامعة : قيادة جامعية لديها القدرة على التوقع و التخيل و التغيير، وثوضيح التوجه الإسنراتيجي للجامعة ،و نحفيز الآخرين و دفعهم

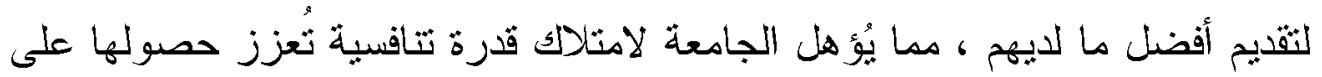

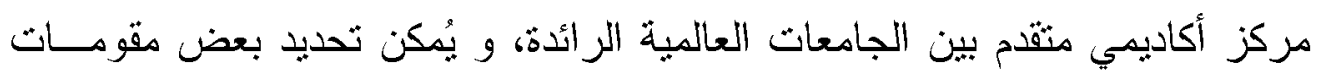

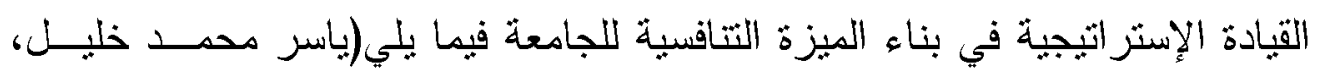
$: \sum r V-\sum r_{0}, r \cdot 11$

> بناء إسنر اتيجية جامعية نُحقق النجاح و الازدهار على المدى الطويل و تُعـزز الميزة التتافسية للجامعة. الفهم الواعي للبيئة المؤسسية الداخلية و الخارجية لاتخاذ قرارات رشيدة حـول

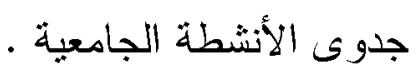

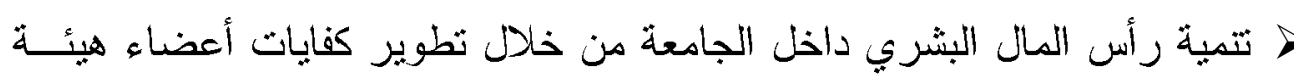
التدريس و العاملين > بناء نقافة تتظيمية فعالة تتميز بالمرونة و القدرة على مواجهة التغيير و إدارتــــ

$$
\text { لتحقيق أهدف الجامعة. }
$$

الإتجاه السادس عشر : استخدام تسويق المنتجات و الخدمات الجامعية في تحقيق الميزة التنافسية الجامعية: بعني تسويق المنتجات و الخدمات الجامعية: "مجموعة الأنشطة المتكاملة التي

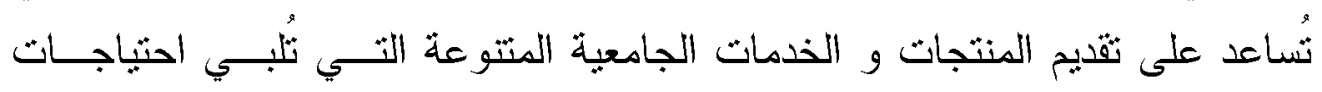
العملاء من خلال عناصر المزيج التسويق المتمثلة في الخدمة و التسعير و الثرويج و النوزيع و فريق عمل التسويق و البيئة المادية و طريق ثقديم المنتجات الجامعية،

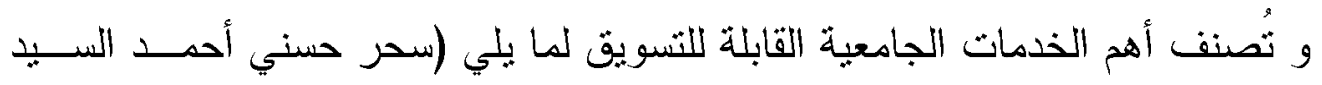

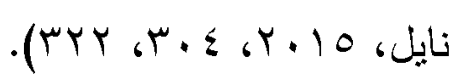

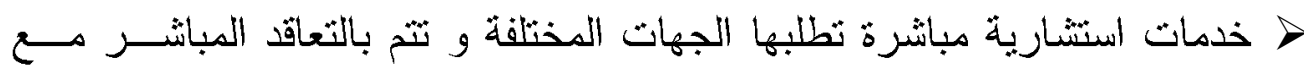

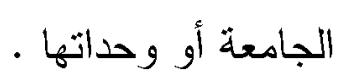

الخدمات التدريبية لنتمية مهار ات العامين في مؤسسات العمال و الإنتاج . 
خدمات تعليمبة و هي تسهم في تطوير خبرات و مهار ات و قدرات الطلاب . خدمات عامة مثل المسنشفيات الجامعية و السكن بالمدن الجامعية و غيرها.

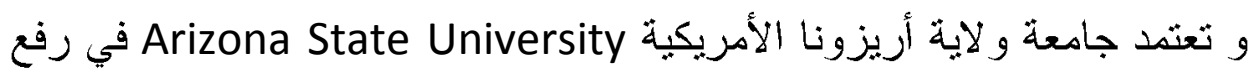
قدرتها التتافسية على تسويق منتجاتها من خلال الثراكة مع مؤسسة كوفمان، و هي

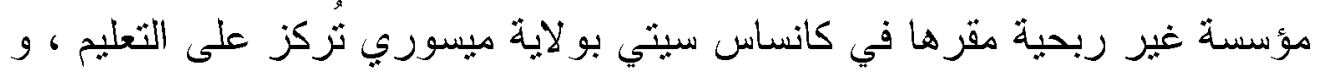
تنتهن زيادة الفرص التسويقية لها. وتثمثل ملامح خبرة جامعة ولاية أريزونا في : تعتمد الجامعة علي تسويق المعرفة العلمية و خبرة أعضاء هيئة التذريس، و تثميـز

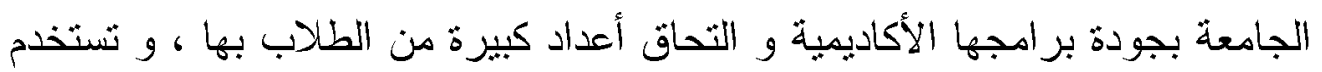

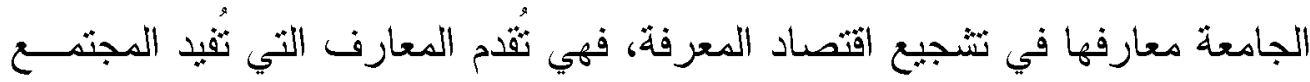
وتُؤثر فيه، ونتفاعل مع كافة الهيئات التي تُحول الأفكار البحثية إلي تطبيقات عملية، و تثوم الجامعة بتهيئة الفرص التسويقية لعرض منتجاتها و تقديم ابتكــار ات حديثــة

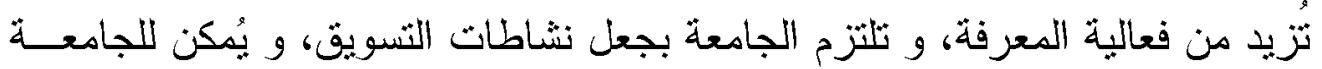

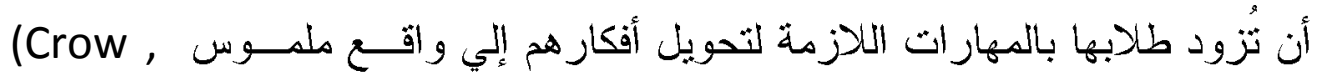
.Michael, Schramm , Carl,2006,1-10) ثنانياً: بعض النماذج الجامعية القائمة على فلسفة الميزة النتافسية ا ـ نموذج الجامعات عالمبية المستوى World- Class- Universities

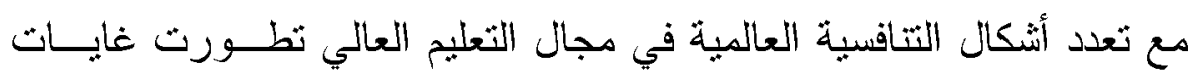

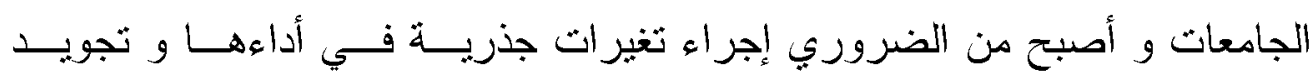

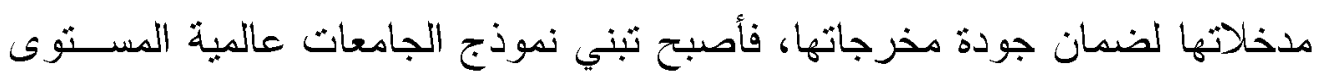

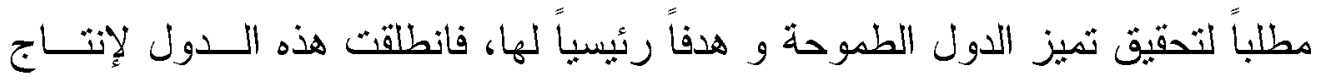
المعرفة الجديدة، و بناء الثقنيات المتطورة، و نطويع الإمكانيات للوصول بجامعاتها

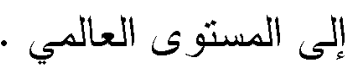
و تعرف الجامعات عالمبة المستوى بأنها: جامعات منتجة للمعرفة مُؤثرة على الصعيد العالمي، و تُقدم خدمات جليلة للإنسانية، و نتصدر التصنيفات العالمية

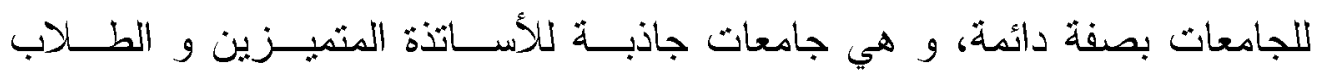




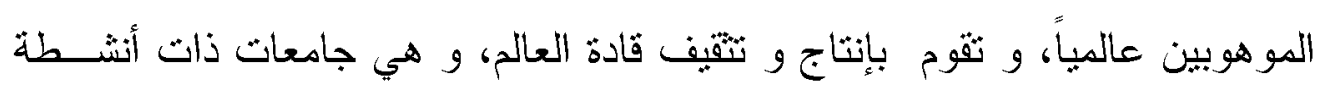

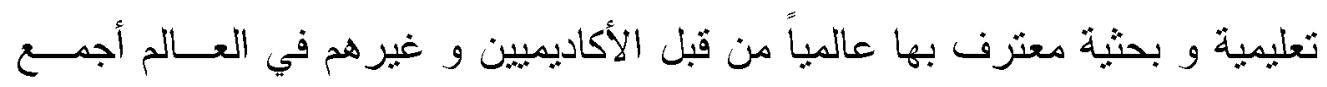

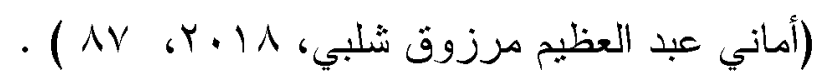

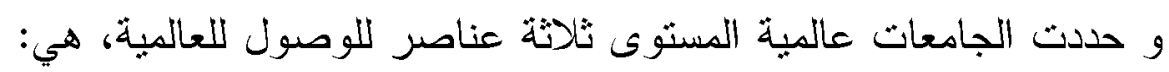

الحصول على نسبة عالبة من الأساتذة المنميزين و الطلاب الموهوبين من أبي مكان

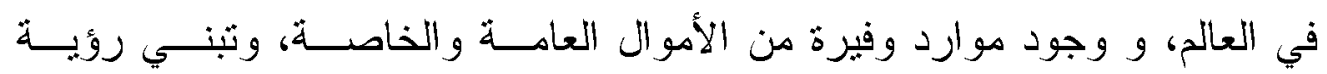

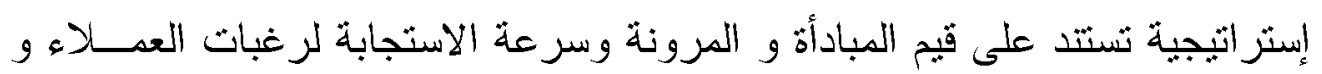

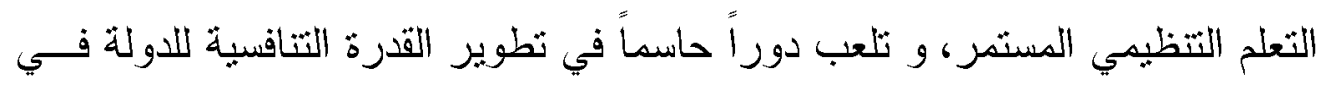
(Qi Wang, Ying Cheng, Nian Cai Liu , إطار الاقتصاد القائم على المعرفة

و من أمثأة الجامعات عالمية المستوى و التي ثتصدر قائمة تصنيف الجامعـات بصفة مستمرة جامعة هارفارد بالو لايات المتحدة الأمريكية، ونتسم الجامعة بعدد مـن فئن جوانب التمبز التي مكنتها هن الحفاظ على المركز الأول فــي التصــنيف العـالمي

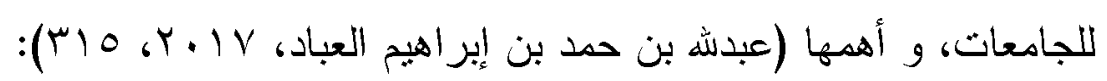

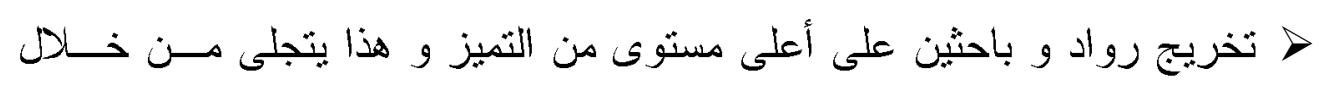

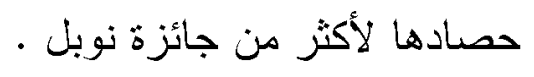
خا ثقديم الاكتشافات الثي تُفيد المجنمع ككل و التوسع في في المعرفة في كل مجــالات الاستقصاء الأكاديمي حصر مجالاتها الدراسية و البحثية و الخدمية في العلوم و الآداب الجيدة التـي

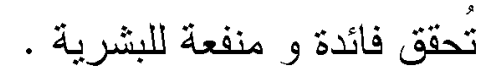

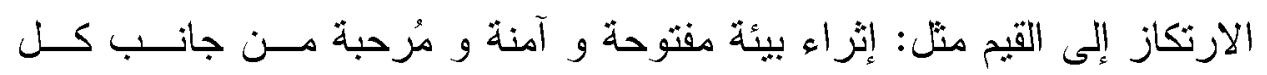

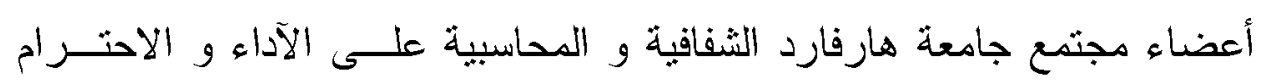

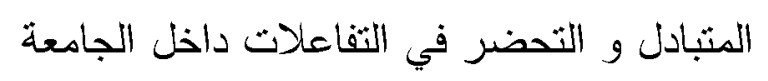

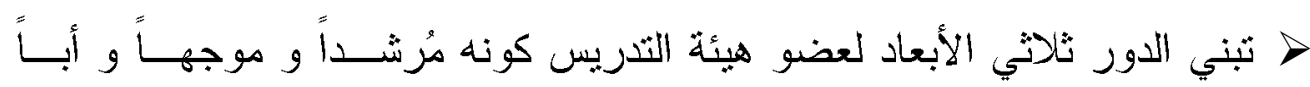
يختص بحماية أبنائه من الطلاب الابعاد لاعضو 
عدم الاقتصار على ثقييم الأقسام و الكلبات لعضو هيئة التدريس ، و إنمــا بــنم

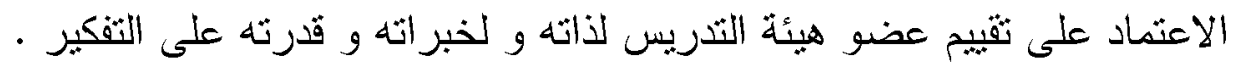

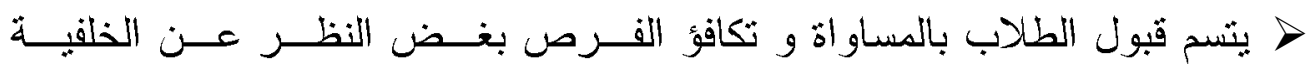
الاجنماعية أو الظروف المالية للمثقدم، كما بثضح ثميز الجامعة في سعيها إلـى بـى

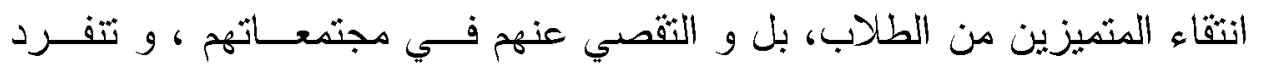
الجامعة برعاية المقبولين و غير المقبولين أيضاً من خلال استراتيجية التحويل . > ينضح ثميز هارفارد من خلال اسهاماتها في حل المشكلات الاقتصادية للمجنمع بنوفير فرص العمل ومعالجة المشكلات البيئية بالإضافة إلى كون الجامعة مركز

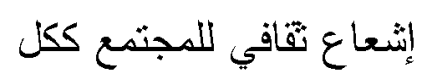

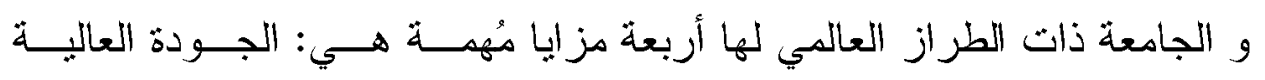
للتعليمهو التفوق في البحث العلمي، و نشر المعرفة، و المساهمات المثميزة في الثقافة

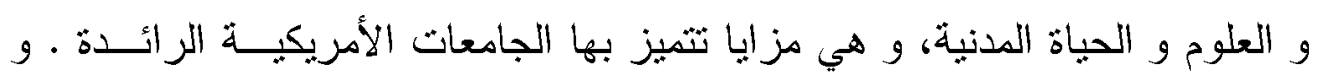

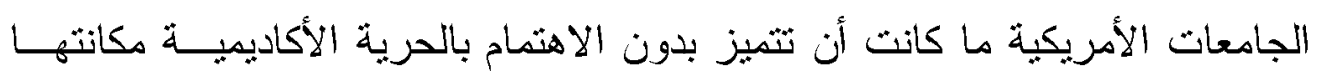
اللازمة داخل الجامعات. و للتأكبد على أهميتها نسترجع قول رئيس جامعة ستانفورد

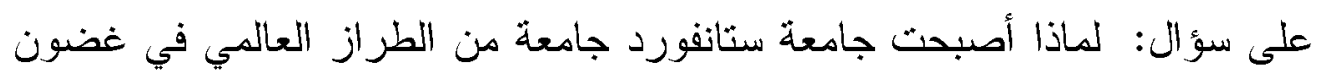

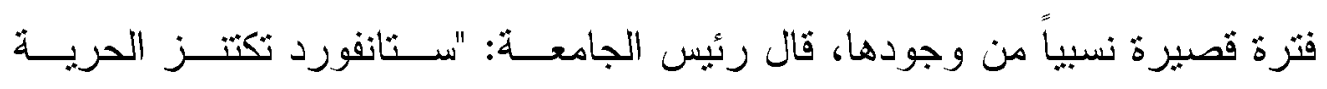

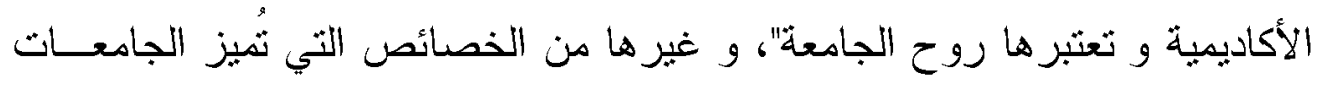

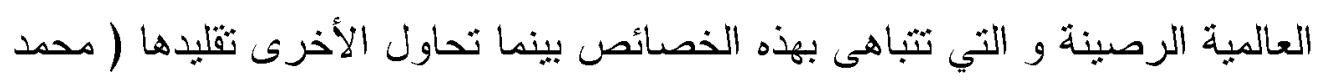

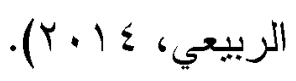

و يوجد ثناث خيارات للجامعات عالمبة المسنوى لنحسين الميزة التتافسية و هي

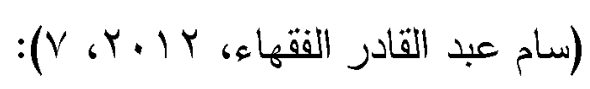

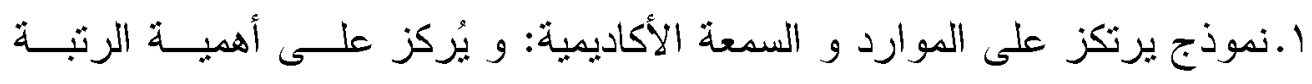

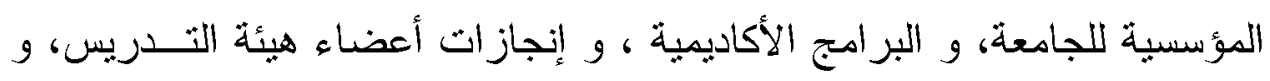

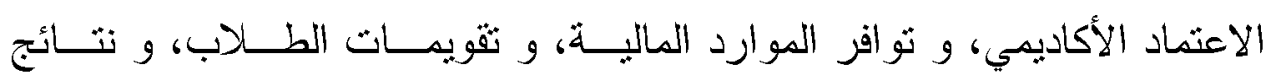

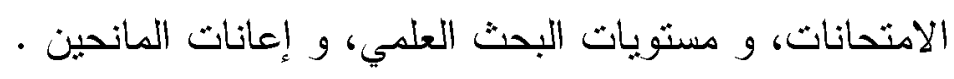


Y. نموذج برنكز على المسثفبد: و يُركز على تجربة الطالب، و جودة الممارسات

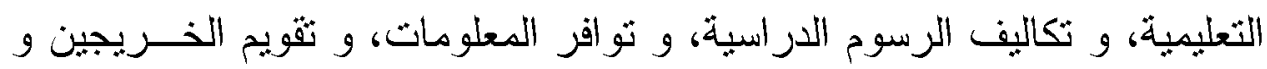

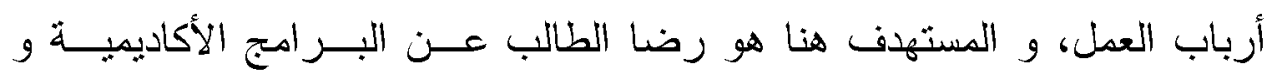

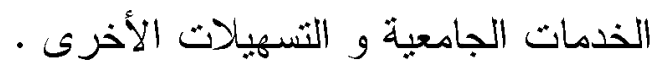

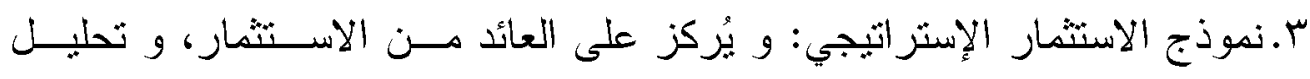

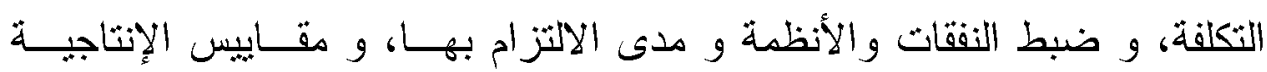

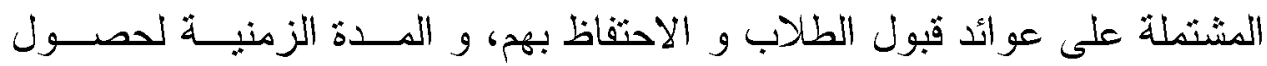
الطالب على الدرجة العلمية، و نققات كل طالب.

r. نموذج الجامعات البحثية: Research universities

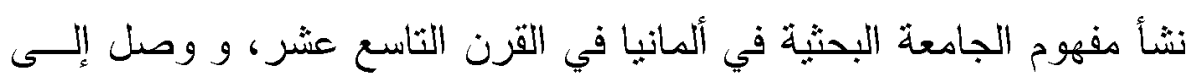
ذروة نجاحه في الولايات المتحدة الأمريكية، و تمحور هذا المفهوم حول ثلاثة مبادئ

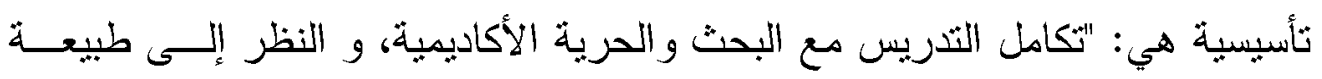

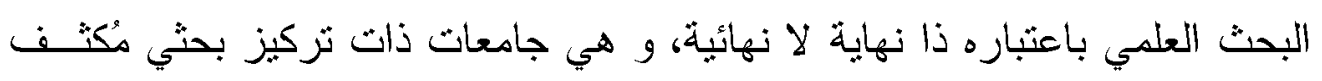

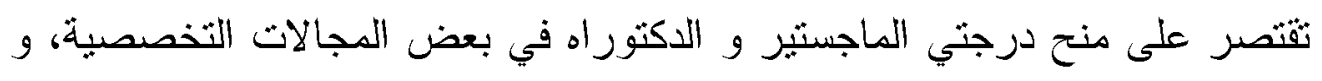

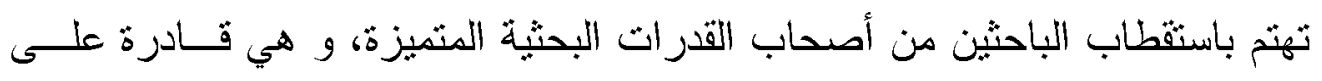

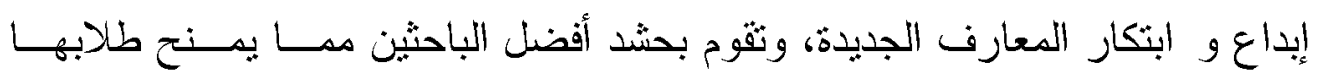

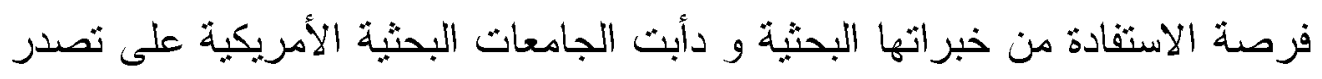

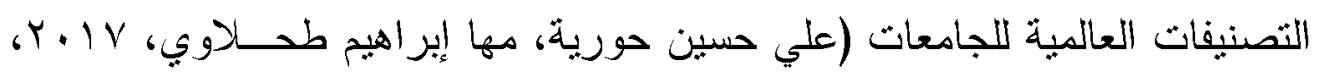
. 109

و تستتد الجامعات البحثية على مجموعة أسس أهمها (تــواف بـن بجــاد

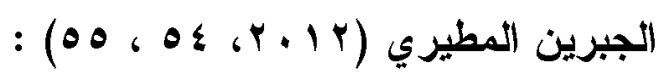

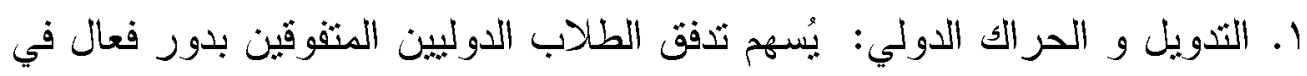
تطوير المستوى الأكاديمي للجامعة و إثزاء نوعية التجربة و خبرات التعلم عن بن

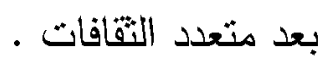


Y. ثزكز المواهب: نتميز الجامعات البحثية بقرة فائقة على جـ ذـب الأشـــاص

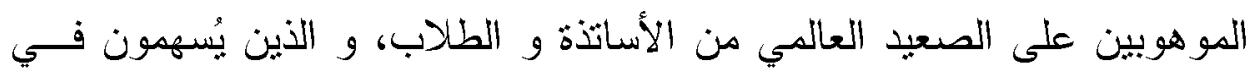
تطوير البحوث العلمية بالجامعة لتحقيق مزايا تتافسية.

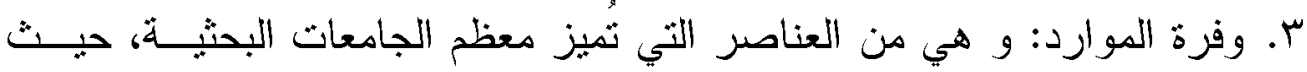

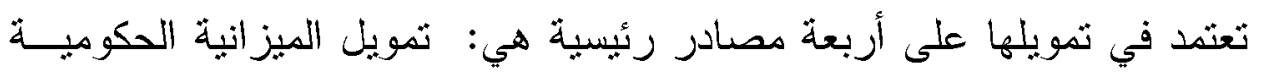

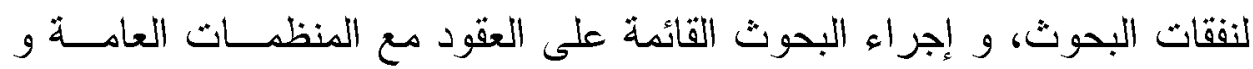
الثركات الخاصة، و العائدات المالية الثي نأثي من الأوقاف و الرسوم الار اسية ء. سمعة الجامعة: تُكون الجامعات البحثية كفاءات علمبة تسنطيع نشر نتائج بحوثها

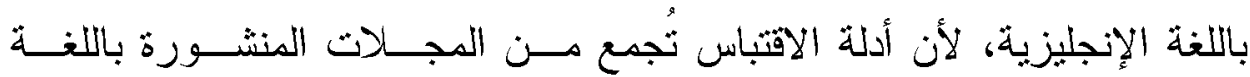

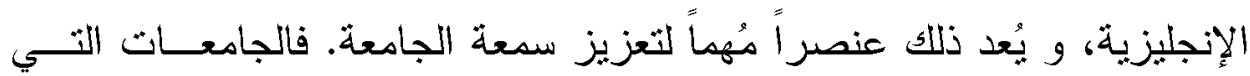
تُرس برامجها باللغة الإنجليزية هي التي تحظى بفرص أكبر لمثل هذا النجاح،

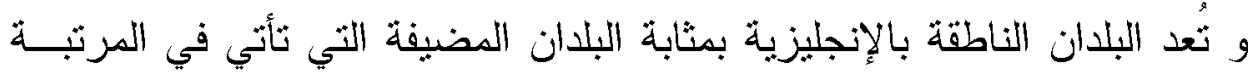
الأولى بالنسبة للطلاب الدوليين. و من أمثلة الجامعات البحثية على الصعيد العالمي جامعة طوكيو البحثية باليابان

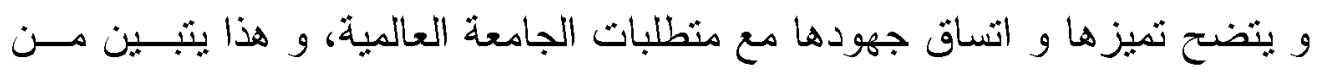

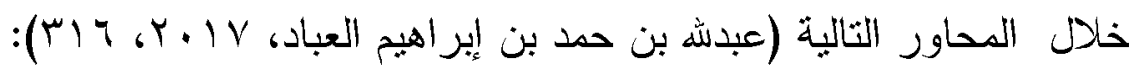

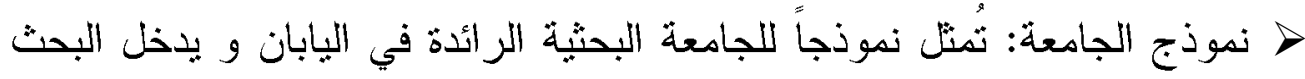
في كافة أنشطنها الرؤية: دعم الروابط البحثية مع قطاعات الإنتاج لتخريج مخترعين بيسـنطيعون التوصل إلى المعرفة بأنفسهم. الرسالة: من خلال سعى الجامعة إلى التميز العالمي و المساهمة في التحضر و

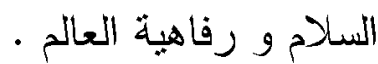
خا المبادئ : ثتميز باهتمامها بالجانب القيمي و الاهتمام بتحقيق مستويات كُنقدمـــة

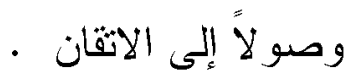


متطلبات تطوير الميزة التنافسية لجامعة أسوان في ضوء الاتجاهات العالمية المعاصرة

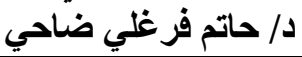

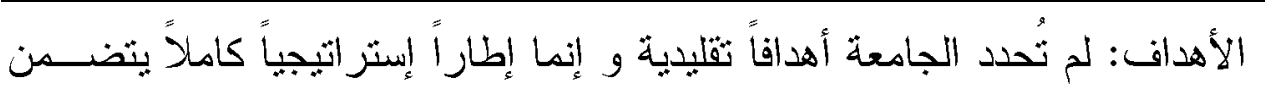
سبعة مجالات، و في كل مجال عدد من الأهداف، و يندرج نحتها عـدداً مسن الهن

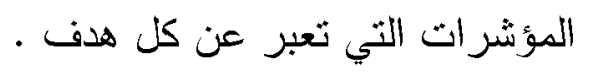
> أعضاء هيئة التذريس: يتضح ثميزهم من خلال انخراطهم في مبدان الصناعة و هون الإنتاج، بالإضافة إلى وجود معهد عالمي للإعدادهم و تأهيلهم للعمل بالجامعة .

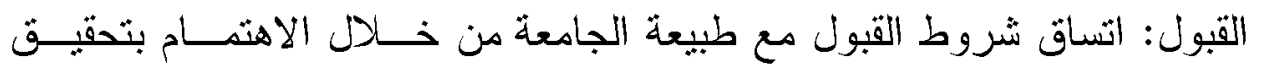
الكفاءة في مختلف تخصصات العلوم و التكنولوجيا، و بثضـح الثميز فــي تتــوع شروط القبول حسب المرحلة الجامعية، أما بالنسبة للطلاب الدوليين فلابد مسن اثقان اللغة البابانية، و قد بلتحق الطالب الدولي كدارس منتظم أو كباحث.

بntrepreneurial University نموذج الجامعة الريادية يُعتبر نموذج الجامعات الريادية من الاتجاهات الحديثة التي ظهرث لإصلاح الجامعات، و تحقيق التميز فيها، و تُعد الريادة من مداخل النطوير التنظيمي الحديثة

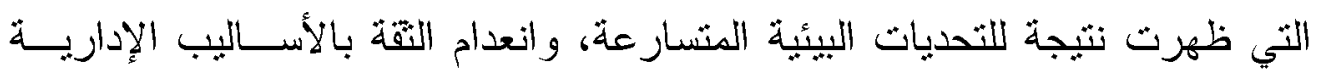
الثقليدية، و رغبة المنظمات في تطوير وضعها القائم لمو اجهة تحديات المنافسة .

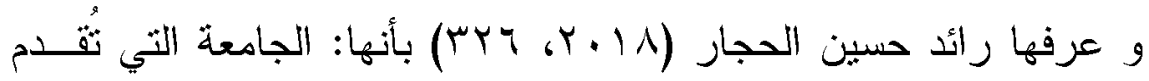
بر امج إبداعية في مجال التدريس و البحث العلمي و خدمة المجثمع، و لديها القــدرة

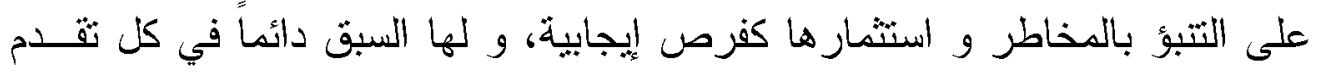

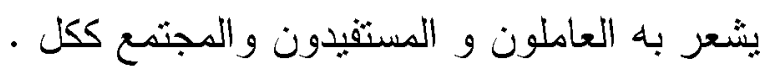
و تشنهف الجامعة الريادية إكساب طلاب الجامعة اتجاهــات و مهـار ات العمل الحر، وذلك لزيادة الوعي بإدراك الفرص الوظيفية، و تدريبهم على مهـار ات

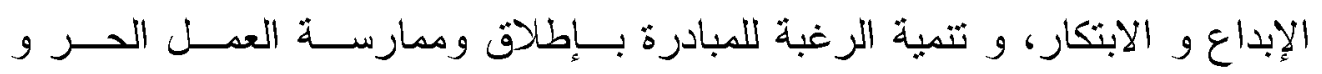
التوظيف الذاتي، و جعل الخريجين خالقين لفرص العمل لا باحثين عنها، و تزويدهم بالقدرة على إدراك الطرق التي يسنطيعون من خلالها المساهمة في النتميــة و فــي 
متطلبات تطوير الميزة التتافسية لجامعة أسوان في ضوء الاتجاهات العالمية المعاصرة

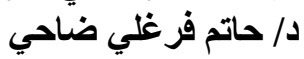

رخاء مجثمعاتهم، و ذلك لعلاج مشكلات البطالــة و الفقــر و العنــف و التهــيش

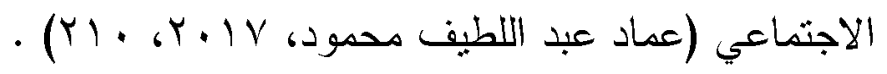

و قد أوضح (Clark, 2004, 353) خمس خصائص للجامعة الريادية:

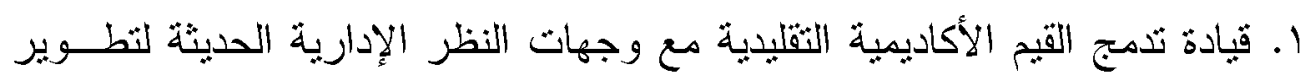

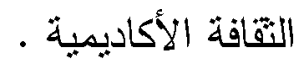
Y. أقسام علمية تُبرم برونوكو لات و شر اكات بين الجامعة و المحيط الخارجي لخلق وظائف جديدة .

ب. تمويل كافي بدعم أبي مشروع ريادي في كل الأقسام العلمية، و تعمل الجامعــة

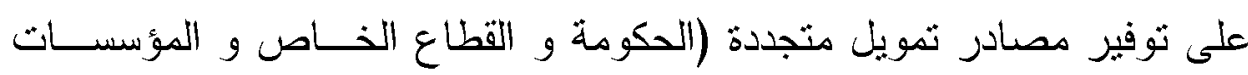
(المانحة)

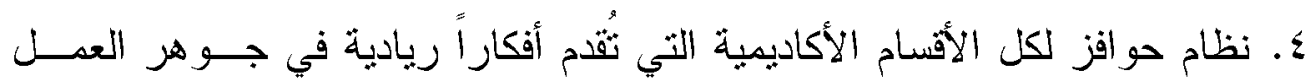
الأكاديمي.

0. وحدة إدارية تتشر تقافة الإبداعو الروح الريادية في كل أرجاء الجامعة . و من منطلبات وصول الجامعة الريادية إلى مزايا تنافسية(صلاح الدين محمد نوفيق،

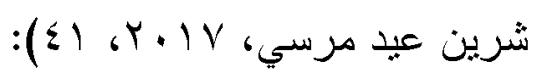
> تحقيق سمعة عالمبة معنزف بها في البحث العلمي و التدريس • > إيجاد أفكار مبنكرة مبدعة يقوم الريادي بنقلها و تحويلها إلى مخرج في ســـوق العمل تحقيق مكانة مثميزة معثرف بها من مؤسسات المجثمع سواء التعليمية أو غيــر التعليمبية .

إقامة تحالفات تسهم في ثز ايد حركة الأساتذة و الطلاب و الأبحاث العلمية .

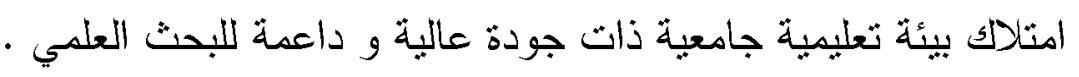

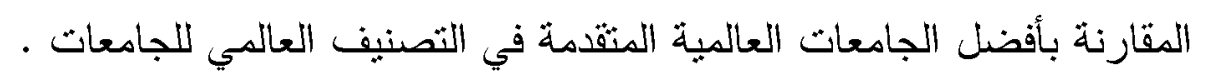
و تُعنبر جامعة واتزلو الكندية من أهم الجامعات الريادية في كندا، و نتمبز بأجندة

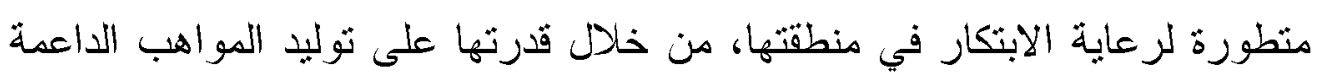


للتميز في مجال العلوم و الرياضيات و الهندسة، ودعــم الثــركات البحثبــة مــع

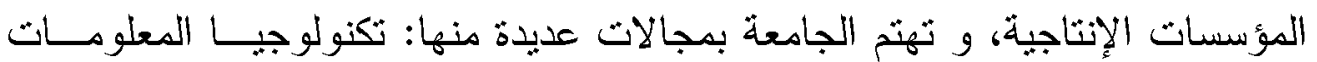
والاتصالات و هندسة البرمجيات و الرعاية الصحية و الييئة و مجــالات الطاةــة

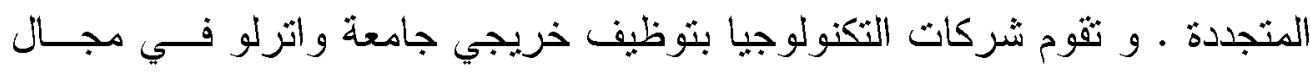

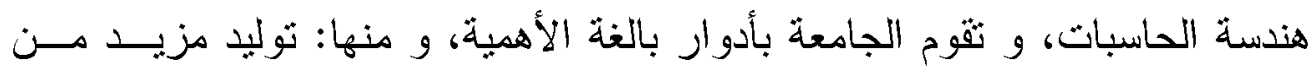

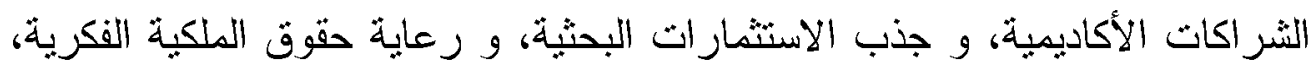
و استثطاب الباحثين المنميزين على المسنوى العالمي، و اجناب العمال الموهوبين

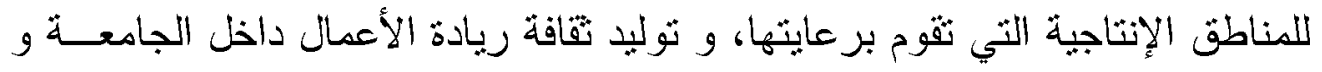

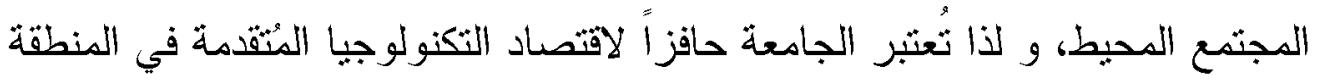

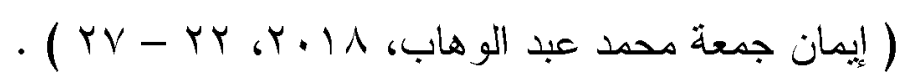

ثنالثاً: بعض الخبرات العات العالمبة في مجال تخليق الميزة التتافسية للجامعات :

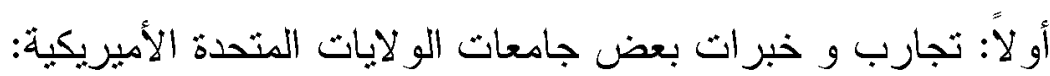

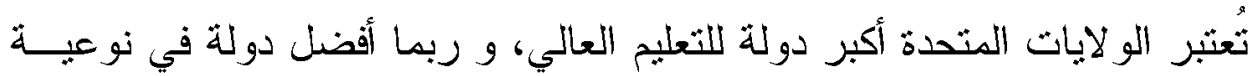

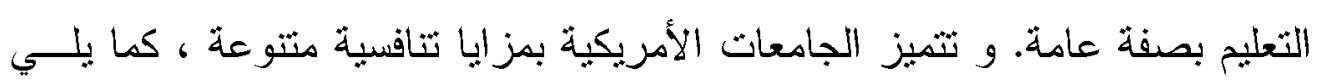

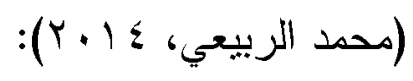

خ تُعتبر جامعة ييل (Yale) من أفضل الجامعات في العالم، و تزى أن مُهمتها أولاً

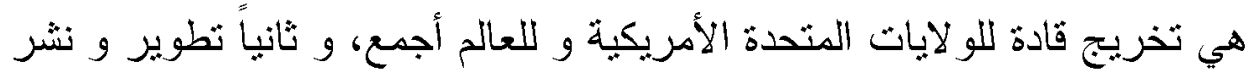

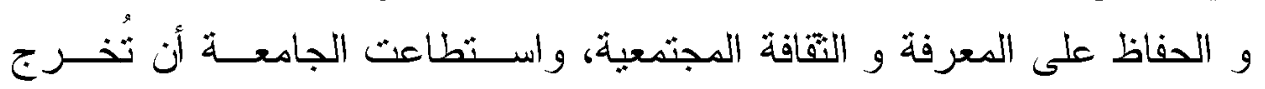

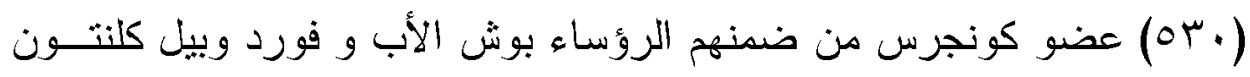
وجورج بوش الإبن، و هي بهذا تكون قد نفذت مُهنتها الأولى. أما المُهمة الثانية

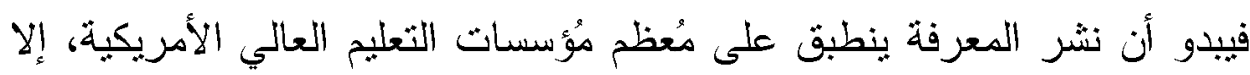

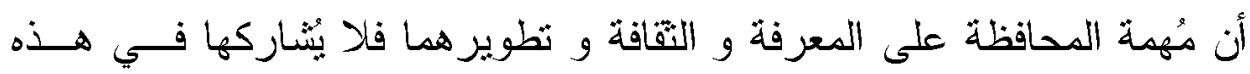

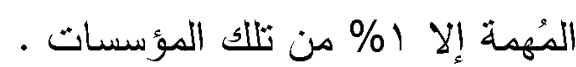

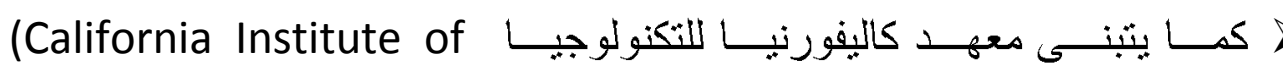
(Technology) 
خلال إجر اء البحوث المتكاملة و التعليم. و هذا المعهد يُدرّس فيه حــوالي . .؛

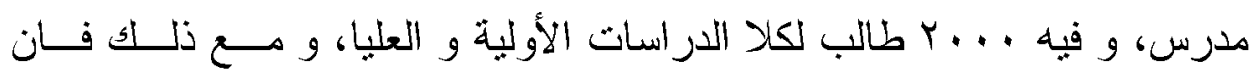

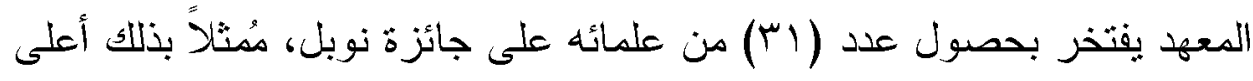

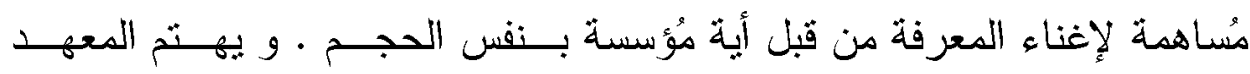
بموضو عات مُحددة هي الطيران و الفضاء و علوم الحياة و الفيزياء. كما تُعتبر جامعة هارفرد (Harvard University) من أعرف و أفضل جامعات

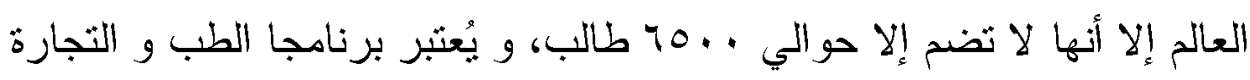

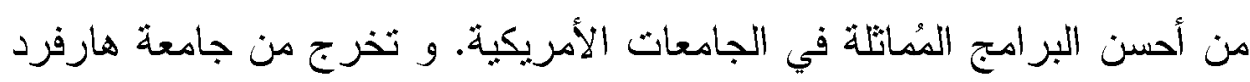

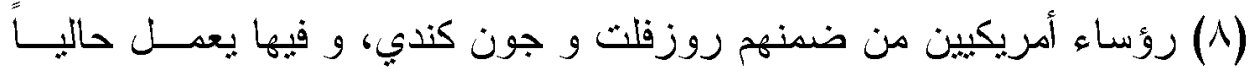

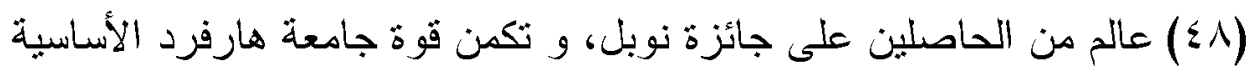

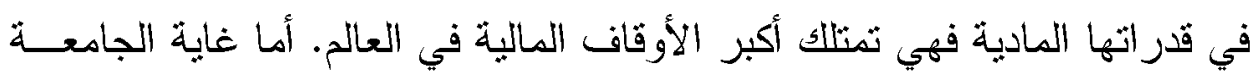
فهي ببساطة "انتاج المعرفة و فتح أذهان الطلاب على هذه المعرفة و تمكيــنهم من الاستفادة القصوى من الفرص التربوية" .

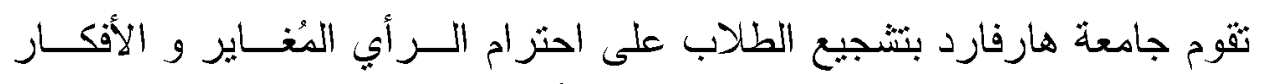

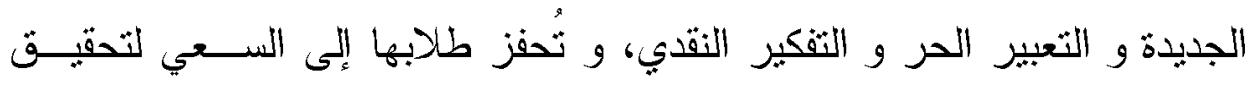
التفوق من خلال التعاون المُثر البناء، كما تُشجع طلابها على تحمل المسؤولية،

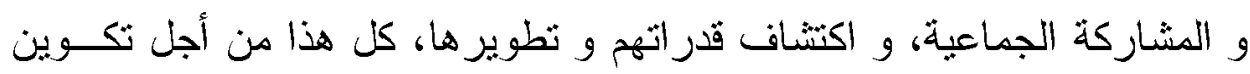

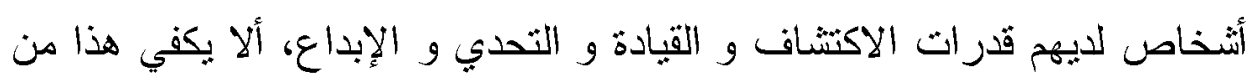

مُهمات لكي تثرشح الجامعة بكل جدارة لتصدر التصنيفات العالمبة للجامعات؟ تنتهدف جامعة هارفرد صناعة الانسان، و ليس مُجرد تعليم الطلاب علوم الطب و الهندسة والآداب والفنون كما تفعل معظم الجامعات، و عمل بجامعة هارفارد بعض من الحاصلين على جوائز نوبل كجيمس واتسون، ونوماس ولر، و و فرنز

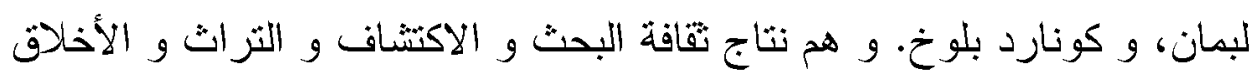

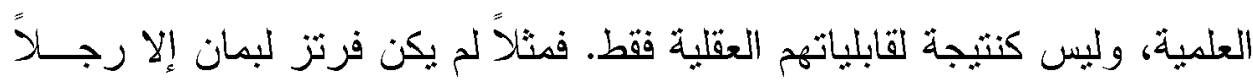


متطلبات تطوير الميزة التنافسية لجامعة أسوان في ضوء الاتجاهات العالمية المعاصرة

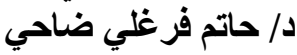

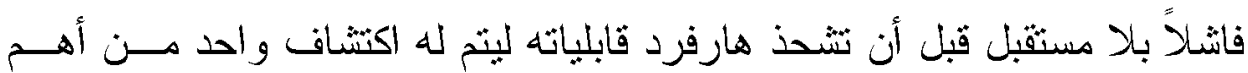
الإنزيمات في صناعة البروتينات .

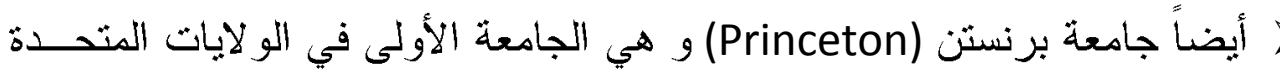

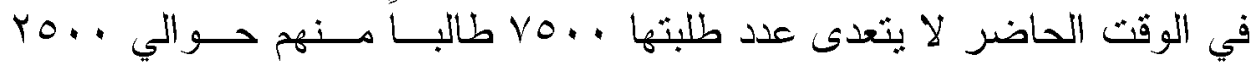
يدرسون دراسات عليا. و لا نمتلك الجامعة أي من أكثر الدراسات رغبة بها في

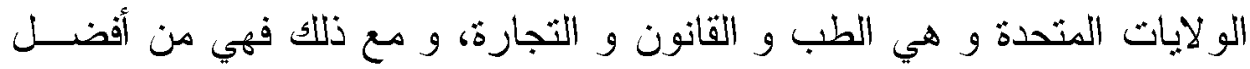
الجامعات في العالم، و السبب في ذلك أنها نتبنى نظام تعليمي من أكثر الأنظمة صرامة و التزام، وباستخدام موارد مُحدودة اسنطاعت من خلالها انتـاج (Yo) من الحائزين على جائزة نوبل (V) المنهم في الفيزياء) ، و (Y (Y) من الفـائزين

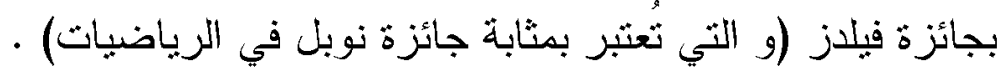
ثانياً: تجارب و خبرات بعض الجامعات الأوروبية

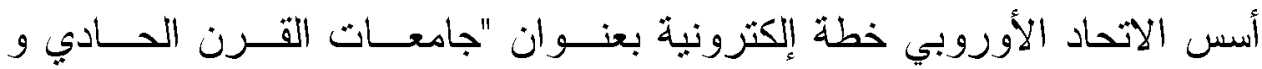
العشرين"، و هي عبارة عن ائتلاف يضم مجموعة من الجامعات الأوروبيـــة التــي تشتهدف نقل التعليم الجامعي إلى الطلاب في آسيا و إفريقيا وأمريكا اللاتينية، و من هن

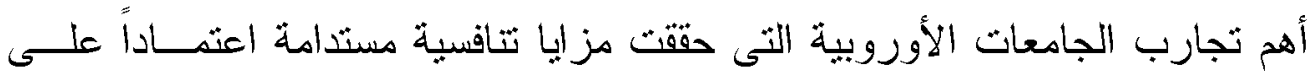

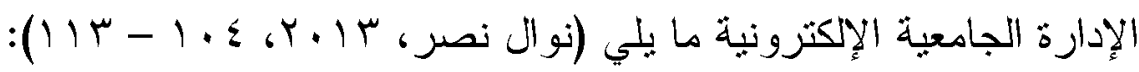
ا . جامعة ليميرك بأيرلندا: Lemyerk University تقع جامعة ليمريك على طول نهر شانون بالقرب من وسط مدينة ليمريك، و تهنم الجامعة بتخصيص برنامج تدريبي لجميع الطلاب في مكان العهـلـ لمــدة (ᄉ)

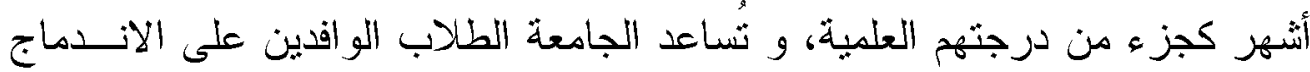

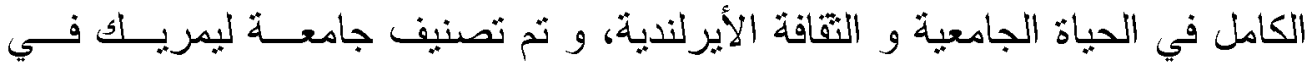
المركز الأول كجامعة مسثقلة خاصة لديها علاقات شر اكة أكاديمبة واسعة النطاق مع عدد من مؤسسات التعليم العالي حول العالم، و تضم الجامعة عدد كبير من الطلاب الو افدين في برامجها الدراسية، وثهتم الجامعة بثقنيات المعلومات و الاتصــالات و التجارة الإلكثرونبة. 
و تثضن البنية الثقنية للجامعة: دائرة أليات بصرية و اتصالات تفاعليـة

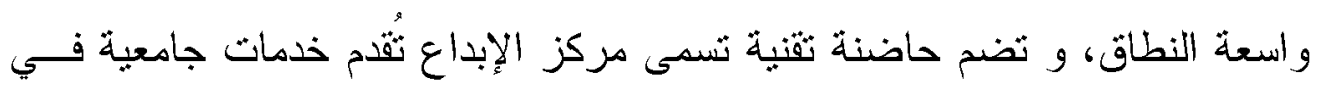

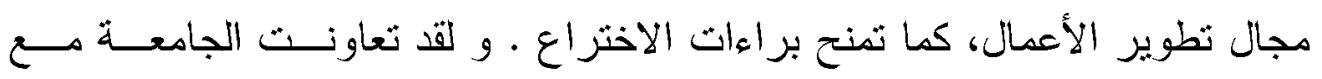

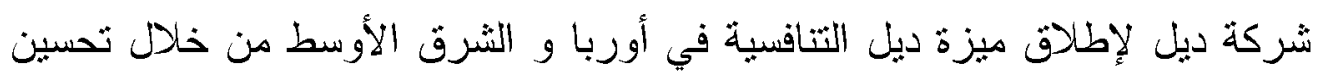

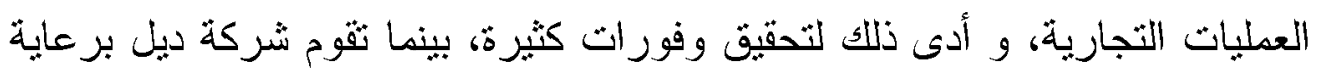

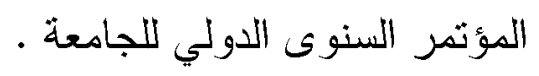
Y.تجربة جامعة أولو بفلندا: Oulo University : تُعتبر جامعة أولو الفنلندية واحدة من أكبر الجامعات في فنلندا، و ثقع في مدينة

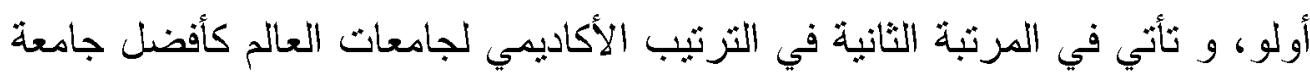

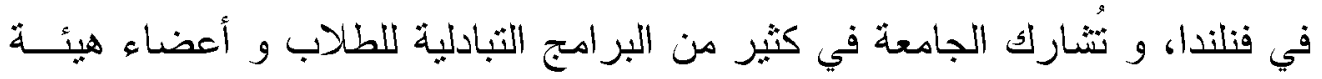

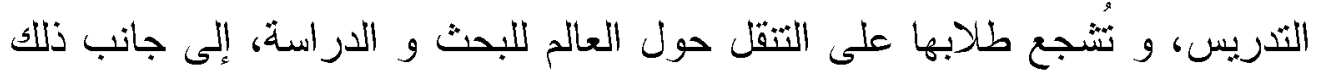

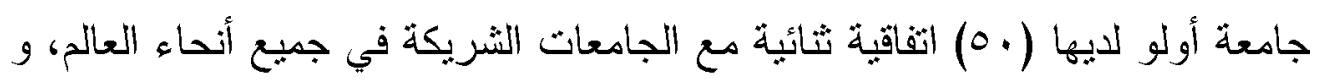
تُقدم الجامعة دنحة لطلاب الماجستير الأجانب بمبلغ (ع.ب) مليون يورو كمُّــاعدة

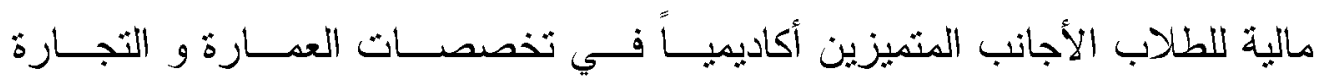
والاقتصاد و التعليم و الهندسة و العلوم. و لقد عقدت جامعة أولو شركات علمبة و بحثية مع شركة التكنوبولس الني تقوم بإدارة و نوجيه الأبحاث الجامعية، و تقدم كافة الخدمات الجامعية المطلوبة من بن

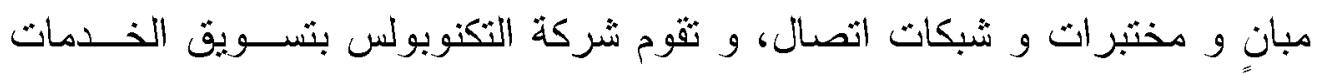

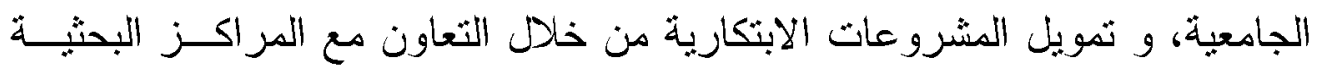
العالمبة، و نجحت الثركة في تحقيق سمعة طيبة و عو ائد مالية عالية.

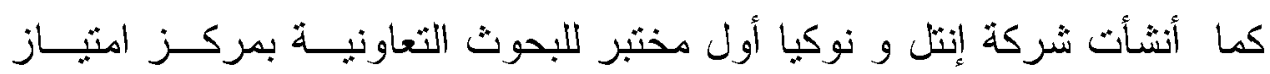

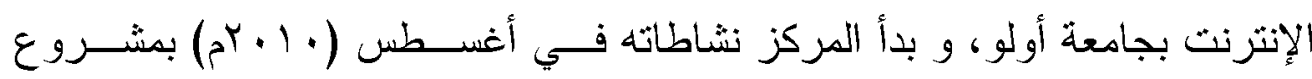

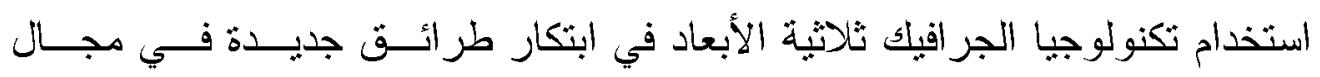
الاتصالات المنتقلة، وساعدت البحوث العلمية المنصلة بالإكترونيات و الضـــئيات 
على جعل هذه الجامعة مكاناً مناسباً لإنشاء مركز الابتكار المشترك بـين إنتـلـل و نوكيا. ب.تجربة جامعة هلسينكي بفلندا: و هي ثُعنبر أحد أهم المر اكز العلمبة المُتخصصة في أبحاث الثقبية الحبوية

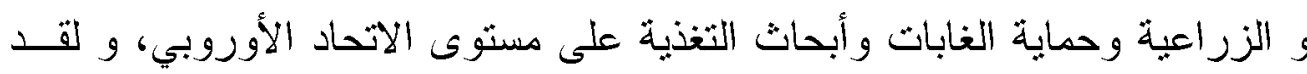

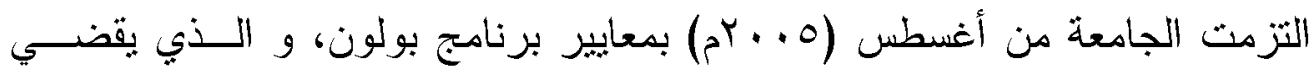
بإنشاء فضاء جامعي مُوحد قبل عام (•(1.rم) في جميع دول الاتحاد الأوروبي بما

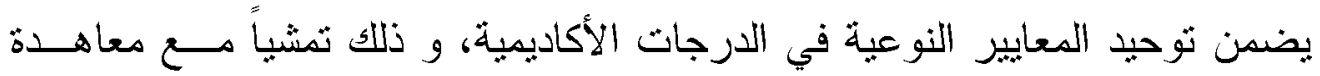
ليشبونة، و ثقوم الجامعة بمنح درجات البكالريوس و الماجسـثير و الــدكتور اه، و و تُعتبر من أفضل الجامعاث البحثية مُتعددة التخصصات في أوروبا.

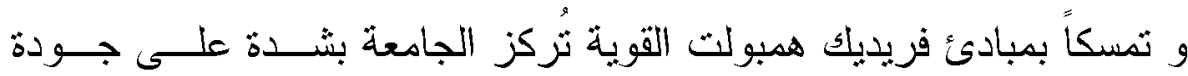

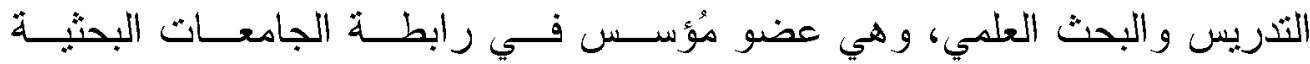

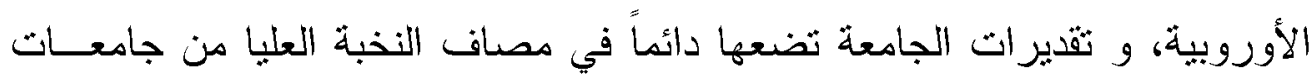

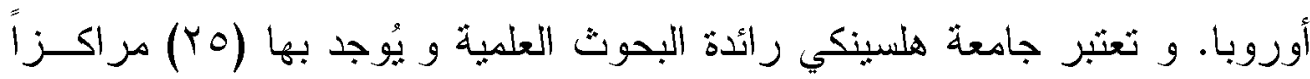
للتميز البحثي، و ثتميز ببحوثها الجامعية الناجحة، و لهذا حصــلت علــى ثمويـلـل مشرو عات ذات قدرة تتافسية عالية، وتثلقى حصة كبيرة من تمويلها مسـن برنــامج البحوث الدولية للاتحاد الأوروبي. و مع نشر تصنيف جامعة شنغهاي جياو تونغ للجامعات العالمية في يوليــو

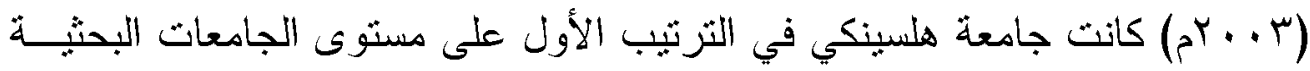
الأوروبية بنسبة (T.T. Y.

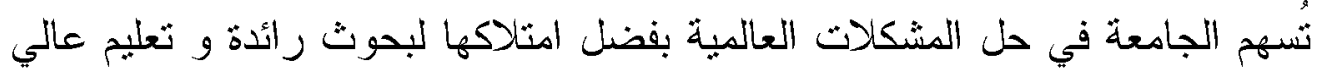
الجودة، و ثقوم الجامعة بثوليد المعارف الجديدة لصالح المجثمع العالمي .

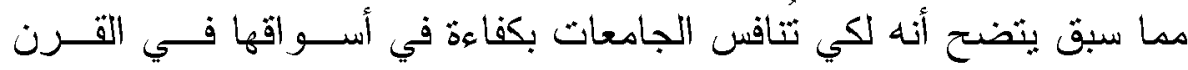
الحادي و العشرين فإنها تحتاج إلى تعزيز كل أنواع المبزة التتافسبة لنضمن ثقــيم منتجات جامعية عالية الجودة، و تحقيق رضا عملائها الداخليين و الخارجيين و خلق 
الولاء لايهم، و تحقيق الإبداع على مسنوى الطالب و عضــو هيئــة التـدريس و الجامعة. و تتبع الميزة النتافسية الجامعية من الاستخدام الفعال للموارد لأدعم عمليات

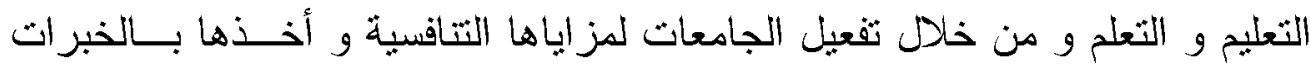

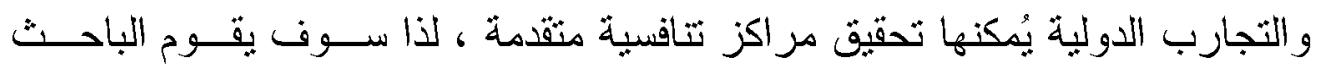

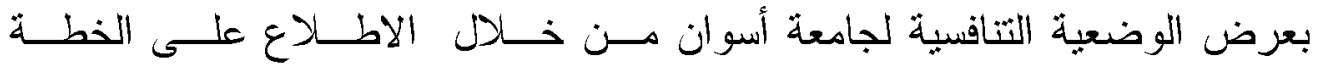

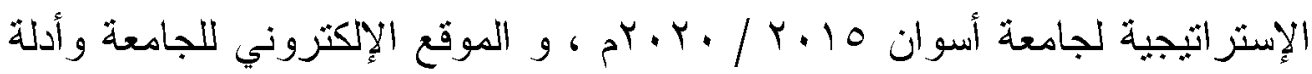
إنجازات الجامعة خلال نفس الفترة ، كما بلي : المحور الثالث: تحليل الوضعية التنافسية لجامعة أسوان

أنتشئث جامعة أسوان فى عام (Y (Y) كجامعة حكومية في أقصى صعيد

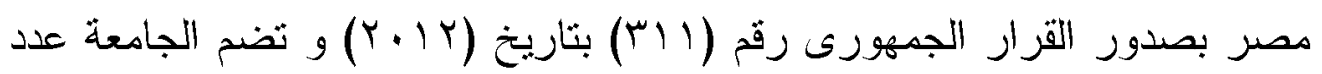

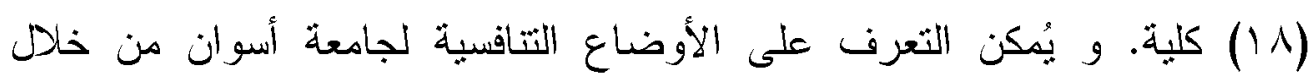
استعر اض النقاط الثالية ( جامعة أسوان، 10 ـب، 1 - ال10)، (الموقع الإلكتروني

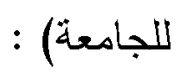
1. تثضمن كليات الجامعة (1) كلبة أساسية، و هى ( كلبة الأداب، كلية التربية، كلبة العلوم، كلية الخدمة الاجتماعية، كلية الهندسة، كلبة الطب البيطرى، كلية الزراعة، كلية التمريض، كلية الطب البشرى، و كلية التجارة، كلية الألسن، كلية الحقوق، كلية التربية الرياضية، كلية الثربية النوعية، كلبة دار العلوم، كلية

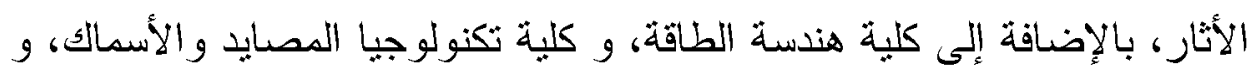
هما تخصصات منميزة تجذب الطلاب من مختف محافظات الجمهورية، و والهابه ثتو افق هذه التخصصات المثميزة مع احتياجات سوق العمل و منطلبات مجتمع

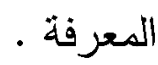
r. تضم الجامعة أيضاً معهدين منميزين، و هما (معهذ التمريض) و يقوم بدور كبير

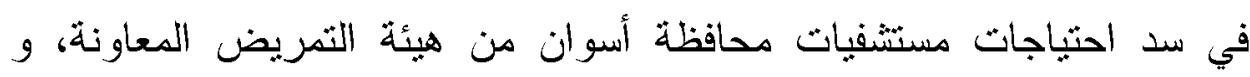
كذلك معهد البحوث و الدراسات الأفريقية ودول حوض النيل ، و يُمُنل منارة

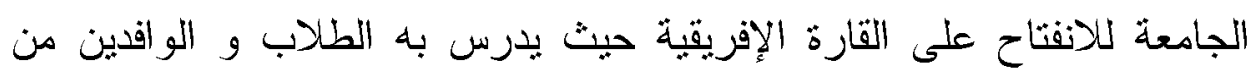


جميع أنحاء العالم دراسات مثقدمة تخدم القارة الإفريقية). و كلاهما يمثل ميزة تنتاقسية لجامعة أسوان.

ب.تقع الجامعة على خمسة مواقع تتضمن صروحاً علمية مختلفة المكان، مدا يمنحها مبزة الثميز المكاني والمساحي، حبث نبلغ مساجة الجامعة الإجمالية ( . بـ) فداناً ثقريباً

ـ. تمثلاك الجامعة طاقة تدريسية و بحثية كبيرة من أعضاء هيئة التدريس و معاونيهم

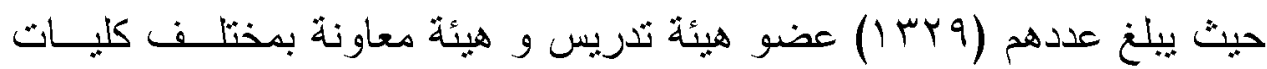

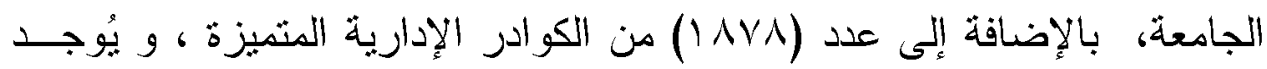

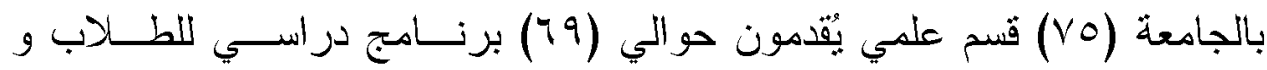

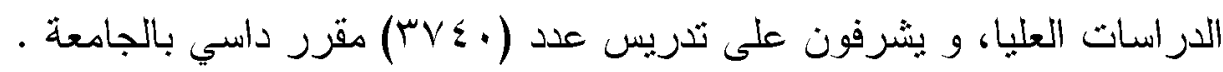

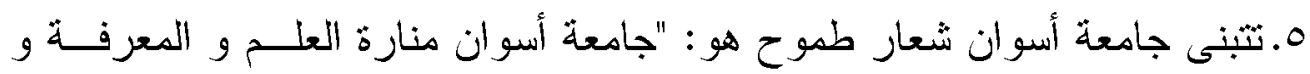
التثمبة المستدامة"'." و تثمثل رؤية الجامعة في: "الريادة و الإبداع في مجال التعليم و إنتاج المعرفة و نشرها و تطبيقها، و تعزيز فرص التتمية لضمان حياة أفضل للمجنمع المحيط" .

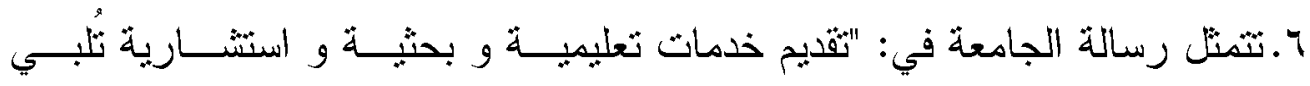
احتياجات المجتمع من خلال ثوفير مناخ تعليمي قادر على إعداد خــريجين ذوبي كفاعة نتافسية طبقاً لمعايير الجودة، و إعداد باحثين ذوي قدرات إبداعبة بشاركون بشكل فعال في تعزيز فرص التتمية المستدامة و تأسيس مجتمع المعرفة".

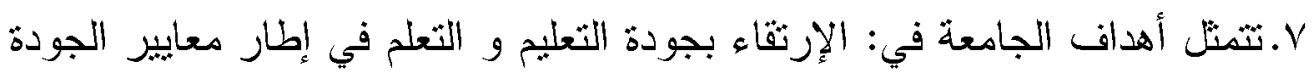

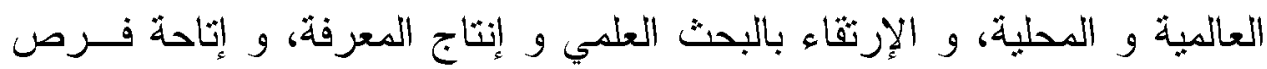
الإبداع و الثميز، و بناء شراكات فاعلة مع المجتمع المحيط بالجامعة ، و تعزيز بإيز

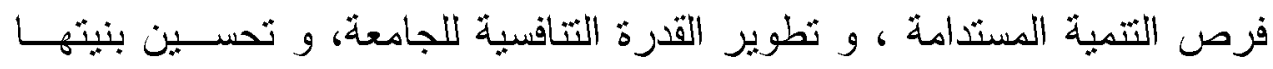

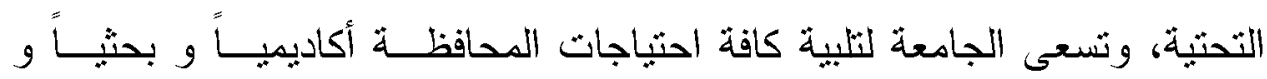
مجنمعياً 
^. تسعى الجامعة نحو انثاء قاعدة بيانات حديثة لرفع كفاءة التعليم و البحث العلمي، و تدريب الكوادر الجامعية على تحقيق الثميز في التعليم و التعلم •

9. تفعيل دور الجامعة في تلبية احتياجات المجتمع و سوق العمل، و رفــع كنــاءة

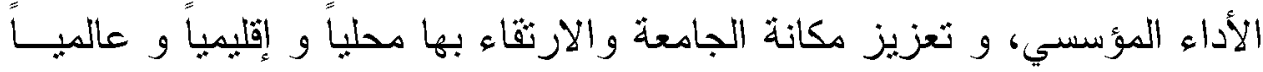

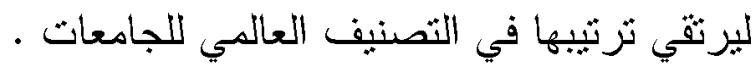
• اـ تُبر الجامعة شبكة علاقات واسعة مع المجلس الأعلى للجامعات و أعضاء هيئة

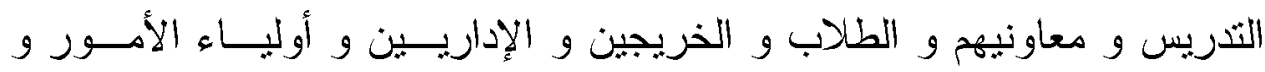
النقابات المهنية و المجتمع المحيط وأصحاب المصالح معها.

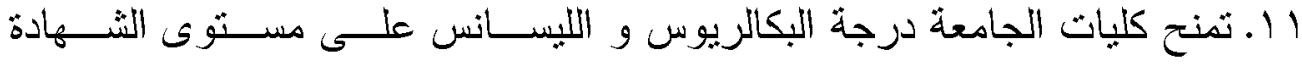

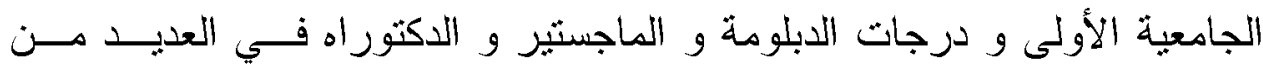

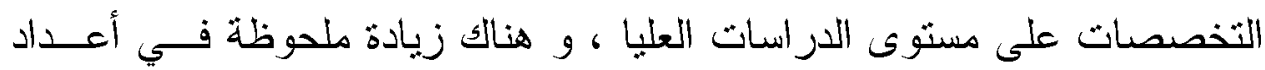
الطلاب الملتحقين بالجامعة نتيجة لتوع الكليات و الأقسام و التخصصات العلمبة حبث يصل عددهم الآن (.... (Y) طالب على صعيد طلاب المرحلة الجامعيـة

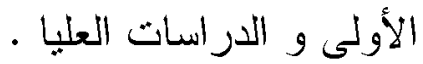

r ا ـوقعت الجامعة العديد من الاتفاقيات العلمبة مع مختلف جامعات العالم المثةـدم في كوريا الجنوبية و ألمانيا و إيطاليا و السودان و غيرهــا ، لتدعيم التعـاون الدولي و نتشيط البحث العلمي بالجامعة .

با ا. قامت الجامعة بتطوير مستشفي أسوان التعليمي التابع للجامعة بتكلفة إحماليــة بلغت ( ـ با مليون جنيه مصرب، حيث قامت باستقطاب الكوادر الطبيــة فائقــة

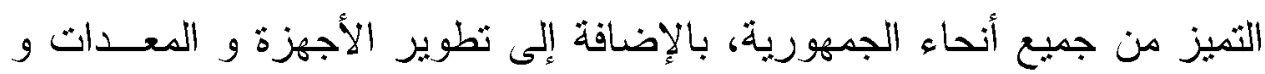
مهار ات العاملين بالمسنشفي لتقديمي خدمات صحية عالية الجودة . ـ ا ـ ثمتلك الجامعة عدد (ro) مركز و وحدة جامعية ذات طابع خاص ثمثل ميـزة تتافسية للجامعة، حيث تُهم تلك المر اكز و الوحدات في تقديم خدمات تعليمية و وحرة بحثية و مجثمعية و استشارية عالية الجودة نؤكد حرص الجامعة على أن نكــون بيث خبرة في المجتمع المحبط بها، و من هذه الوحدات: وحدة الدراسات الييئة، 
وحدة المطبعة المركزية، و مركز ضمان الجودة و الاعنماد، و مركز التـدريب وتكنولوجيا المعلومات، و مركز التعليم المفتوح ، و مركـز التــدريب و ريــادة

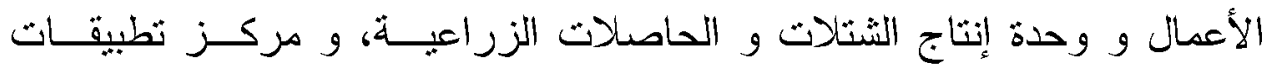

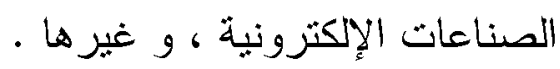

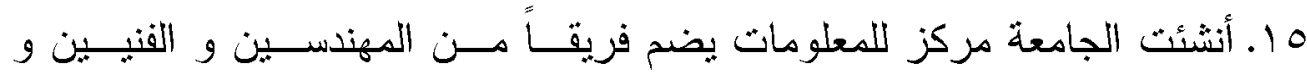
الإداريين الذين يعملون في مجالات ميكنــة إدارة الجامعسـة، و التـدريب علـى

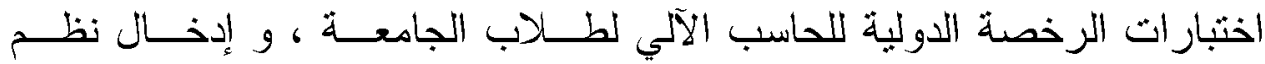
المعلومات و الاتصالات في جميع العمليات الإدارية بالجامعة .

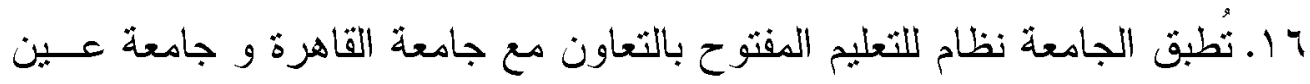

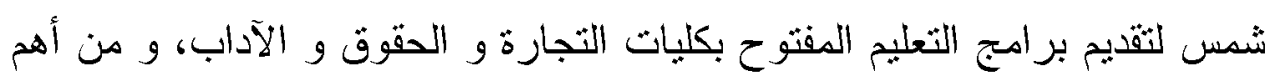

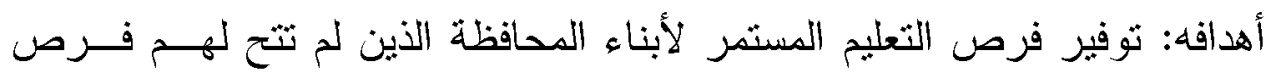

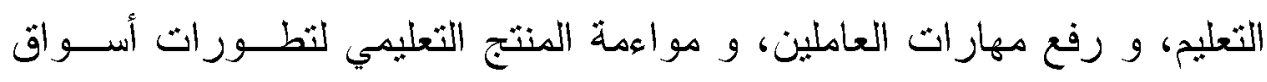
العمل . الع

I V تثمثل القيم الحاكمة للأداء الجامعي بجامعة أسوان فــي : تـداول المعرفــة و مشـاركتها مع الآخرين، وثقدير الكفاءات التعليمية و البحثيــة و المجتمعيـة ذات

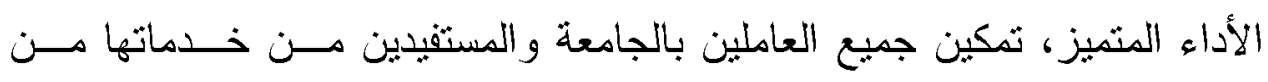
المشاركة في صنع و اتخاذ القرار، و توفير مناخ نتظيمي داعم للابتكار، وتحقيق ونيق العدالة وتكافؤ الفرص بين جميع العاملين بالجامعة و بين الطلاب أيضاً ، علاوة

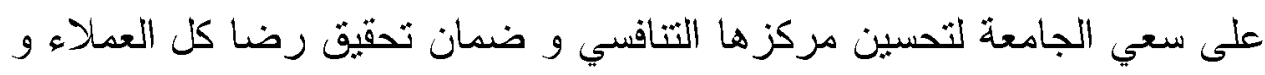

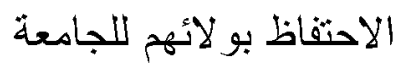

1 1. تبني الجامعة لفلسفة تقوم على توجيه كافة الأنشطة الأكاديميــة و الإداريسـة و المالية نحو تحقيق رضا العملاء و الأطر اف المعنية ، مع النطوير المستمر لجودة الخدماث التعليمية التي تقدمها الجامعة . 9 1. من المزابا التتافسية لجامعة أسوان ثطبيق برنامج جامعة الطقل، و هو هو برنامج در اسبي ثابت و مُوحد نتبناه أكاديمية البحث العلمي و التكنولوجيا بوزارة التعلـيم 


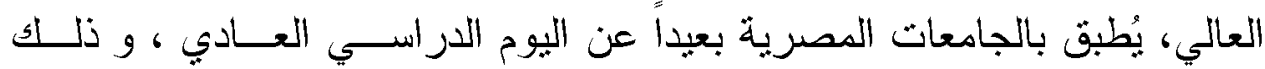

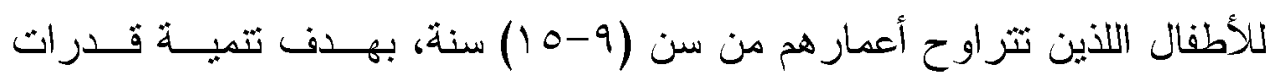
الأطفال و ثوسيع مداركهم ، و خلق روح الإبداع و الابتكار، و حثهم على الفهم و الحوار و المناقشة الو اعبة و ذلك من خلا تدريبهم على كافة الانثطة المهارية

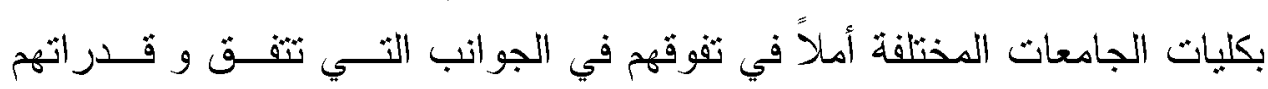

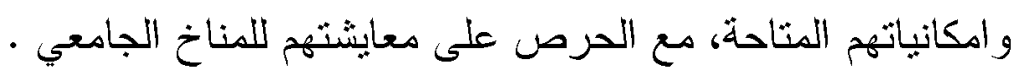
تدل المؤشرات السابقة على جهود التحسين المستمرة التي تبذلها جامعة أســـوان لتحسين مركز ها النتافسي ، و التفكير الإستراتيجي لنظوير منظومة العمل الجامعي ،

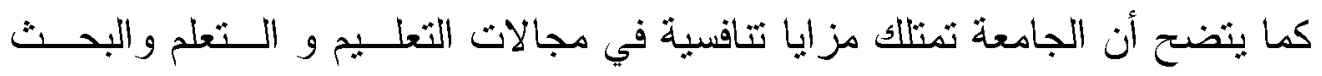

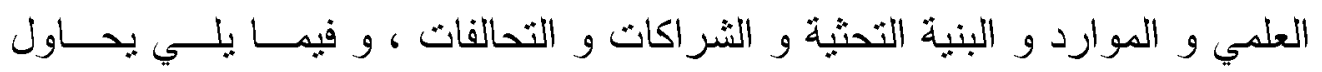

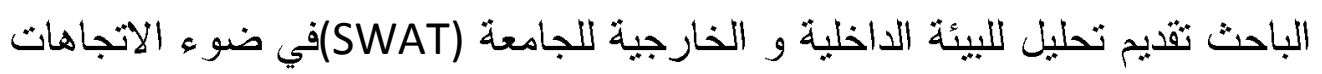
العالمية المعاصرة كما بلي: تحليل البيئة الاخلية و الخارجية لجامعة أسوان (SWAT) : جدول (1) تحليل لعناصر البيئة الداخلية و الخارجية لجامعة أسوان

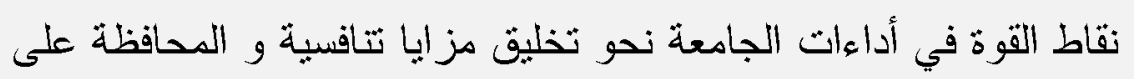
استمراريتها

| تحظى جامعة أسوان بسمعة أكاديمية منميزة حققتها منذ إنشائها محلياً و إقليمياً r التوسعات الإنشائية لمشروعات البنية التحتبة للجامعة و التي شملث بناء دقار

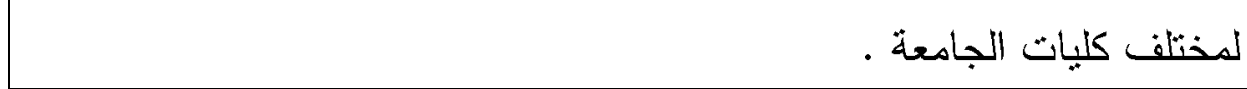
r | ثو افر منظومة قيمية كأساس للتقافة التنظيمية و مظلة للعلاقات الإيجابية بـين العاملين بالجامعة ع حصول عدد من كليات الجامعة على مشروعات لإنشاء نظم داخلية لضــمان

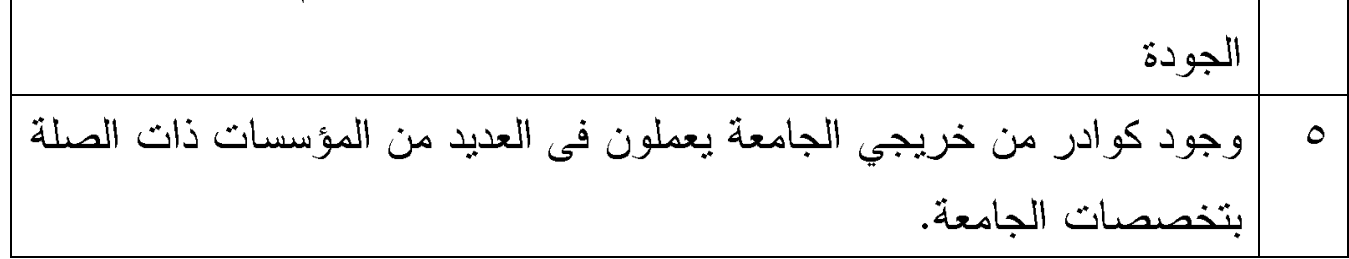


متطلبات تطوير الميزة التنافسية لجامعة أسوان في ضوء الاتجاهات العالمية المعاصرة

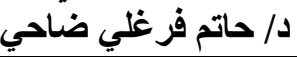

\begin{tabular}{|c|c|}
\hline نقاط القوة في أداءات الجامعة نحو تخليق مزابا نتافسية و المحافظة على اسنمر ارينها & \\
\hline و ثو افر معامل للحاسب الآلي مُتاحة لأعضاء هيئة التذريس و الطلاب بالجامعة & 7 \\
\hline الدو افر مصادر للتعلم بالجامعة و منها المكتبات الرقميــة و المنصــلة بأحسـدث & $V$ \\
\hline التأهيل و التدريب المستمر للكوادر البشرية من أعضـــاء هيئــة التـدريس و & $\lambda$ \\
\hline المقوم الجامعة بقو اقل طبية و اجنماعية وزر اعية و بيطرية لخدمــة المجتمـع & 9 \\
\hline 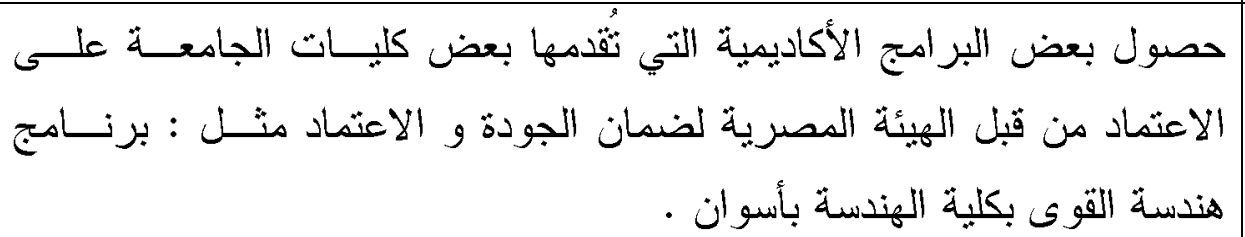 & 1. \\
\hline ثانباً: نقاط الضعف لاى جامعة أسوان و الني تحول دون نحقيق الميزة & ? \\
\hline بأعداد الطلاب . وجود في أعداد أعضاء هيئة التدريس ببعض كليات الجامعــة مقارنــة & 1 \\
\hline 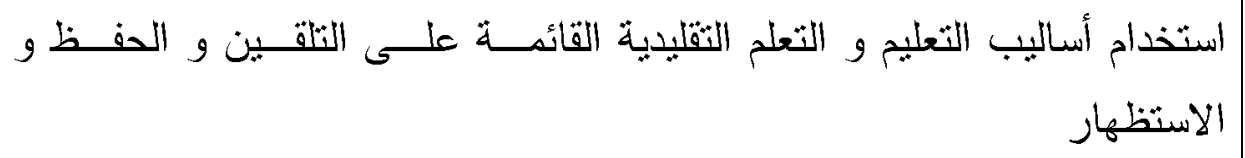 & $r$ \\
\hline |ستخف جودة المعامل البحثية الخاصة بأعضـــاء هيئــة التـدريس و آلبــات & $r$ \\
\hline 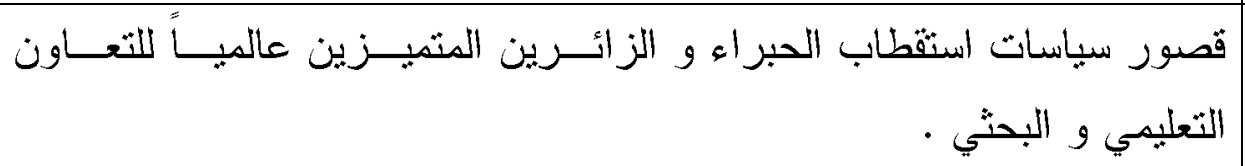 & $\varepsilon$ \\
\hline ضعف الثشر اكة مع أولياء الأمور و أصحاب العمل و المستقيدين من خـدمات & 0 \\
\hline
\end{tabular}


متطلبات تطوير الميزة التنافسية لجامعة أسوان في ضوء الاتجاهات العالمية المعاصرة

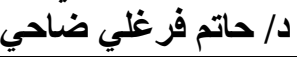

\begin{tabular}{|c|c|}
\hline نقاط القوة في أداءات الجامعة نحو تخليق مزابا ثتاقسية و المحافظة على استمراريتها & \\
\hline التنافسية . تفعيل وحدة مثابعة الخريجين و ضعف أدائها بالجامعة مما يقلل مزاياهــــ & 7 \\
\hline 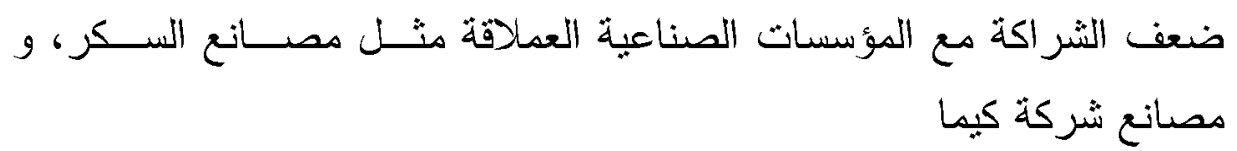 & $V$ \\
\hline 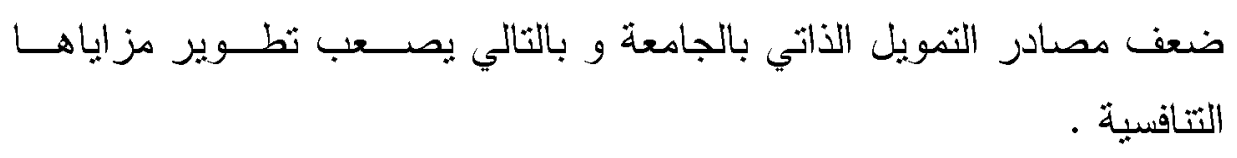 & $\lambda$ \\
\hline ضرف مستوى الكتاب الجامعي (المذكرة) و قلة المراجع و الدوريات العلميــة & 9 \\
\hline أساليب الثقويم تحديث المناهج و المقررات الدر اسية الجامعية في معظم الكليات و ضعف & 1. \\
\hline ثالثاً: الفرص المتاحة للجامعة في تعزيز مز اياها التنافسية ضــوء الاتجاهــات & ? \\
\hline توجه الدولة لتتمية إقليم جنوب الصعيد و توجه القيادة السياسية لتقديم مزيد من الإقليم & 1 \\
\hline في أعداد الطلاب الطلب الاجتماعي على التعليم الجامعي بمحافظة أسوان مها يُتيح زيــادة & $r$ \\
\hline ثو افر فرص للاستفادة من مشروعات الجودة الممولة من وزارة التعليم العالي & r \\
\hline تزابد المنح المجانية المقدمة من الهيئة العامة لضمان الجودة و الاعتماد . & $\xi$ \\
\hline والجامعية جوائز محلية و دولية مُحفزة للجامعة لدعم الإبداع على كافة المستويات & 0 \\
\hline تتامي دور مستشفي أسوان التعليمي في تقديم مزيــــــــن الخــدمات الطيـــة & 7 \\
\hline
\end{tabular}


متطلبات تطوير الميزة التنافسية لجامعة أسوان في ضوء الاتجاهات العالمية المعاصرة

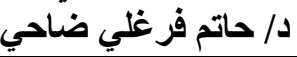

\begin{tabular}{|c|c|}
\hline نقاط القوة في أداءات الجامعة نحو تخليق مزايا نتاقسية و المحافظة على استمر اريتها & ? \\
\hline التخصصية المتميزة . & \\
\hline 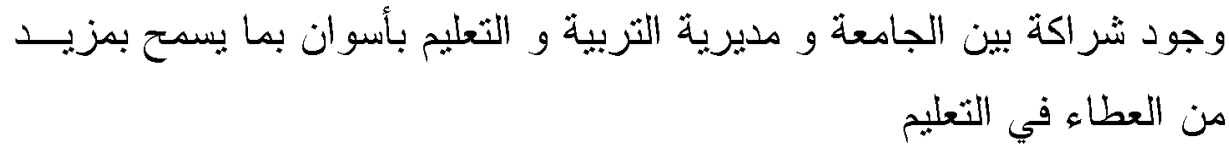 & $v$ \\
\hline الباحثين الجادين إجراءات النشر الدولي في الدوريات العلمية العالمية و ثيسيرها أيسـام & $\lambda$ \\
\hline خدمات واسعة للمر أة بأسوان جامعة أسوان و فرع المجلس القومي للمر أة فـي تقـــيم & 9 \\
\hline لرابعاً: التهديدات و المخاطر المتوقعة في مجال الاحتفاظ بالمزايـــا التتاقسـيـة & 5 \\
\hline زلتعليمبة و البحثية حدة المنافسة الإقليمية و العالمبة في مجال تجويد الخــدمات الجامعبــة & 1 \\
\hline تصنسر الدعم المقدم للجامعة من قبل المجتمع المحلي المحيط بالجامعة بســبب & r \\
\hline 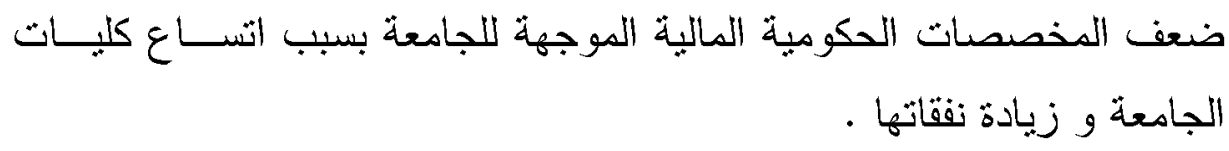 & r \\
\hline ذلك . التغير في احتياجات سوق العمل و ضعف قدرة البرامج الأكاديمية على مواكبة & $\varepsilon$ \\
\hline تزايد قو اعد حماية حقوق الملكية الفكرية و تأثيره على قواعد النشر و التوثيق & 0 \\
\hline كميزة تنافيد اللوائح الإدارية بمؤسسات التعليم العالي بحيث تعوق مرونة الجامعـات & 7 \\
\hline التطور الهائل في تكنولوجيا المعلومات و الاتصالات بحيث يصعب مو اكبته و & 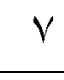 \\
\hline
\end{tabular}


متطلبات تطوير الميزة التنافسية لجامعة أسوان في ضوء الاتجاهات العالمية المعاصرة

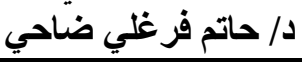

نقاط القوة في أداءات الجامعة نحو تخليق مزايا نتافسية و المحافظة على استمراريثها

ارتفاع ثوقعات العملاء و المستفيدين من خدمات الجامعة بسأن جودة المنتج أو

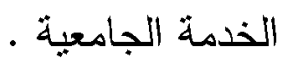

9 • 1 |تدهور مستويات الطلاب القادمين من مرحلة الثانوية العامة في اللغتين العربية و الإنجليزية و غيرها .

1 | غياب العمل بروح الفريق في مجال البحث العلمي و غياب التتــاركية مــع المؤسسات البحثية ذات الصلة

مما سبق ينضتح امتلاك الجامعة للعديد من المزايا التتافسبة و التـي تحثــاج لإجر اءات فعالة للحفاظ عليها ، و الآن يقوم الباحث بدر اسة مبدانية لتثبــيم جامعسـة

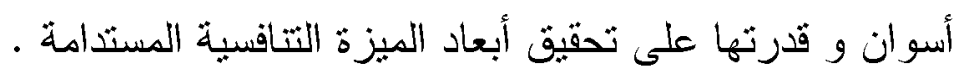
المحور الر ابع: إجر اءعات الدر اسة الميدانية

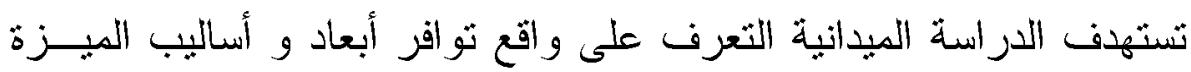
التتافسية الجامعية بجامعة أسوان من وجهة نظر القبادات الجامعية و أعضداء هيئـة التدريس و معاونيهج بالجامعة، و لذا قام الباحث بثصميم اسنبانة نتكون من سنة أبعاد

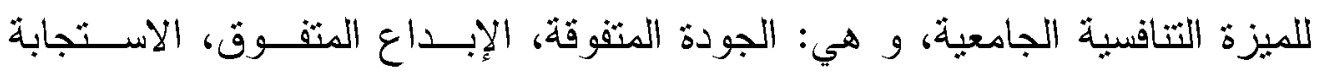

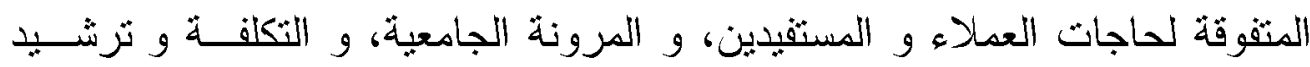

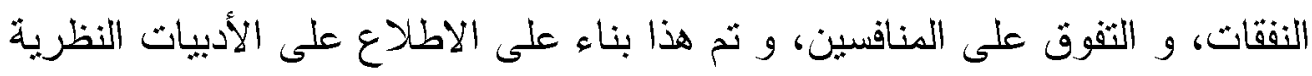
بهذا الصدد . بهات أدوات الاراسة الميانية: الهندا:

لتحقيق أهداف الدراسة المبدانية قام الباحث بتصميم استبانة نتكون من ســنة

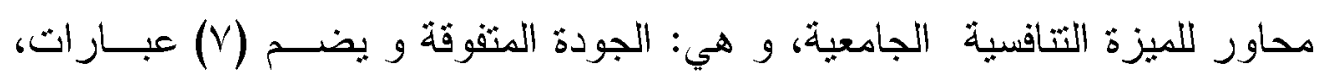


الإبداع المتفوق و يضم (V) عبار ات، الاســنجابة المتفوقـة لحاجــات العدـلاء و

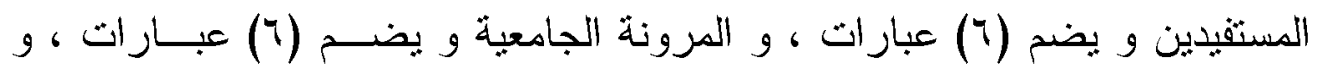

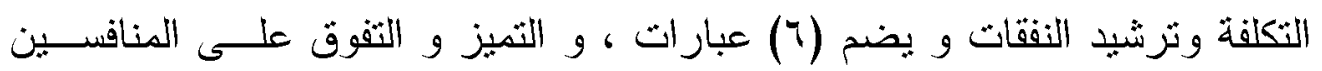

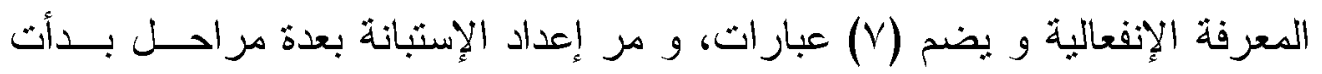

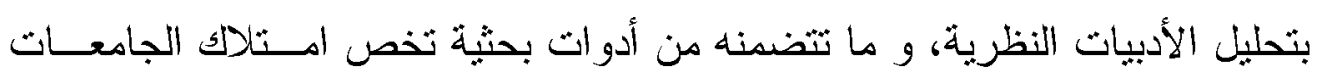

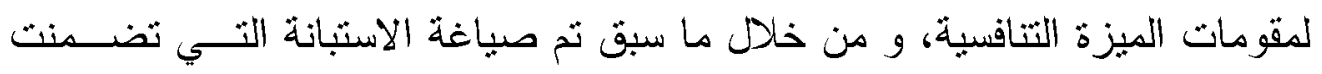

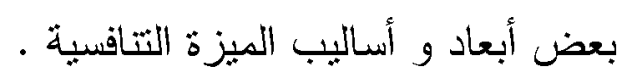

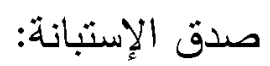

يُقصد بصدق الإستبانة" مقدرثها على قياس ما وضعت من أجله"( فؤاد البهي

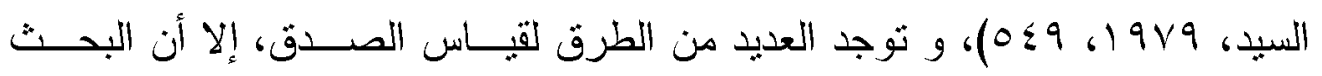

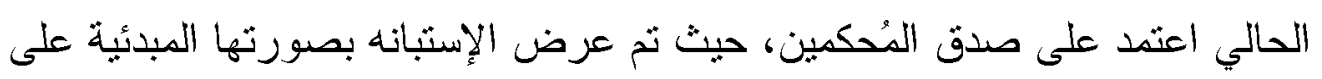
بعض الأساتذة المتخصصين في التربية و علم النفس لنحكيم العبار ات والتأكد مـن التـن

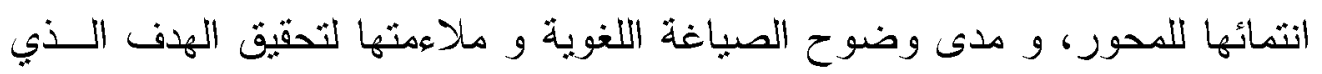

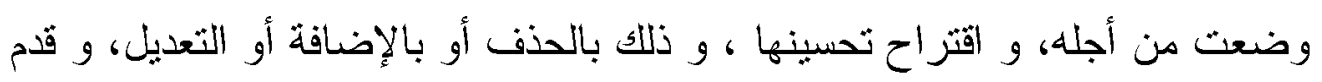

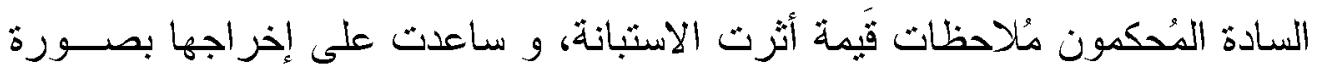

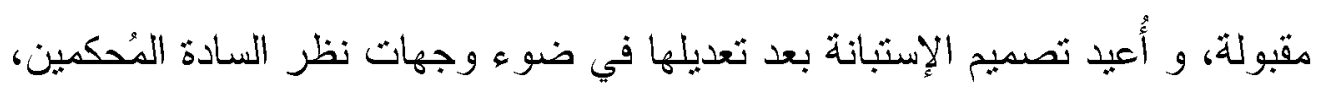
و بحساب معامل ثبات الإسنبانة ككل يُكن حساب معامـلـل الصــدق الــذاتي مــن المعادلة:

الصدق الذاتي = معامل الثبات = القيمة مقبولة لصدق الإستبانة)

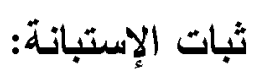

يُقصد بثبات الإستبانة أن تُعطي نتائج واحدة إذا ما أعبد ثطيقها على العينة

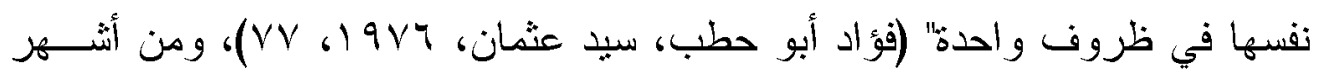

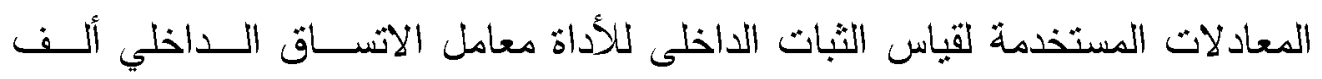
كرونباخ (Cronbach Alpha)، حيث نم سحب عدد (مro) استمارة ثم نطبيقها على لنى 
متطلبات تطوير الميزة التنافسية لجامعة أسوان في ضوء الاتجاهات العالمية المعاصرة

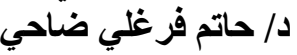

عبنة عشو ائية من أعضاء هبئة التدريس بكلية التربية جامعة أسوان، و نم التحقق من

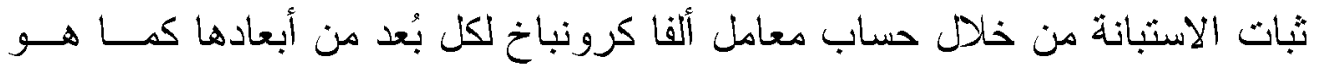

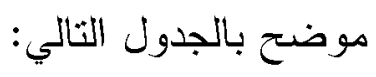

جدول (Y) معاملات الثبات لأبعاد الاسنبانة

\begin{tabular}{|c|c|c|c|}
\hline قيم ألفا كرونباخ & العبار ات & الأبعاد & م \\
\hline 0.914 & 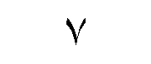 & الجودة المثقوقة & 1 \\
\hline 0.920 & v & الإبداع المثفوق & r \\
\hline 0.938 & 7 & الاستجابة المتفوقة لحاجات العملاء و & r \\
\hline 0.955 & ז & المرونة الجامعبة & $\varepsilon$ \\
\hline 0.958 & 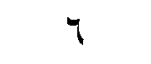 & التكلفة و ترشيد النفقات & 0 \\
\hline 0.957 & $\checkmark$ & التميز و التفوق على المناقسين & 7 \\
\hline 0.940 & rq & المنوسط & \\
\hline
\end{tabular}

يتضح من الجدول السابق أن قيمة معامل الثبات للاســثبانة ككـلـل بلغــــ (

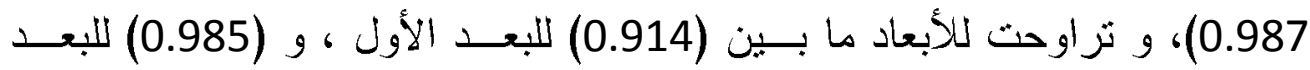

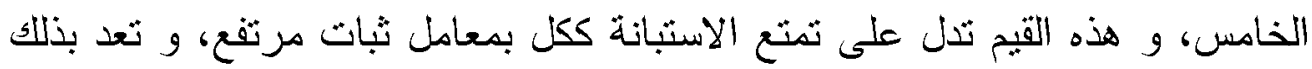

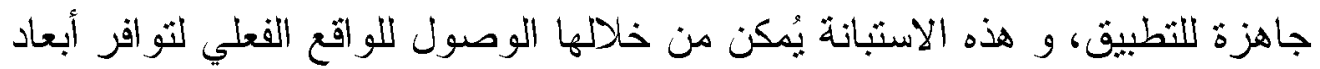
الميزة النتافسية الجامعية بجامعة أسوان من وجهة نظر القبادات الجامعية و أعضاء هيئة التّريس و معاونيه بالجامعة، و ذلك من خلال الإجابة على بنود الاستبانة، و كل بند يبدأ بعبارة تثريرية نثطلب إعطاء المفحوص درجة تثراوح من (1) إلى (0)

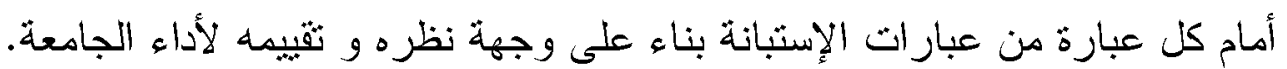
عينة البحث و خصائصها: تضم جامعة أسوان مجموعة من الكلبات الجامعية المنميزة، و نــم نطبيــق

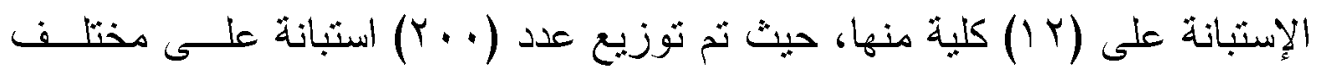


متطلبات تطوير الميزة التتافسية لجامعة أسوان في ضوء الاتجاهات العالمية المعاصرة

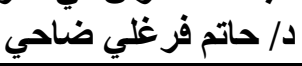

كلبات الجامعة و ثم استرجاع عدد (، (1) استبانة منها للقبادات الجامعية و أعضاء هيئة التذريس و معاونيهم، و يُوضح الجدول الثالي وصفاً لهذه العينة: جدول (r) ثوزيع عينة التطبيق على كليات جادعة أسوان

\begin{tabular}{|c|c|c|c|c|c|}
\hline العدد & الكلية & $\hat{\imath}$ & العدد & الكلية & b \\
\hline IV & كلية العلوم & V & 41 & كلية التربية & 1 \\
\hline V & كلية الألسن & $\wedge$ & rr & كلية الخدمة الاجنماعية & r \\
\hline$r$ & كلية التربية الرياضية & 9 & rr & كلية الآداب & $r$ \\
\hline r & كلية الآثار & 1. & 11 & كلية التربية النو عية & $\varepsilon$ \\
\hline r & كلية تكنلوجيا المصايد و & 11 & $\varepsilon$ & كلية التجارة & 0 \\
\hline iv & كلية الزر اعة و الموارد الطبيعية & ir & 11 & كلية الهندسة & $y$ \\
\hline 11 & & حلي & 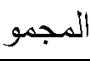 & & \\
\hline
\end{tabular}

المعالجة الإحصائية:

\section{استخدم الباحث الأساليب الإحصائية الآتية:}

ا. الأوزان النسبية: لحساب الأوزان النسبية لاستجابات عينة البحث في كل عبـارة

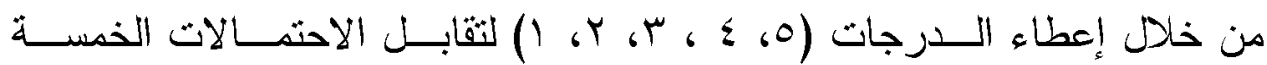
المحثلة ، و يُستخرج الوزن النسبي من العلاقة:

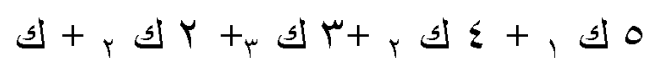

الوزن النسبي (ق)

$$
\text { ن }
$$

حيث تُمثل (ك ر، ك ب ، ك ب ، ك ؛ ؛ ، ك م) تكرار ات الاستجابات في كل احتمال من الاحتمالات الخمسة، (ن) هي عدد أفر اد العينة . 


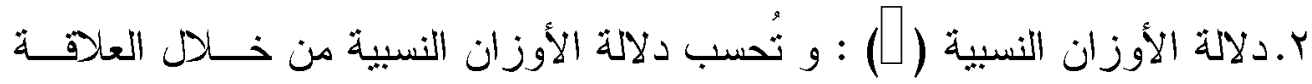

$$
\begin{aligned}
& \text { (أحمد سيد خليل، بدري أحمد أبو الحسن، } 999 \text { 1، V + ()): }
\end{aligned}
$$

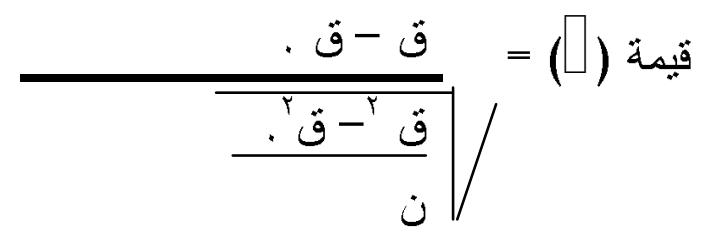

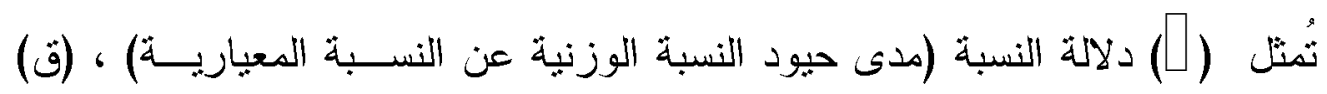
النسبة الوزنية المستخرجة، (ق.) هي النسبة الوزنية المعيارية ، وتساوى (.0..)،

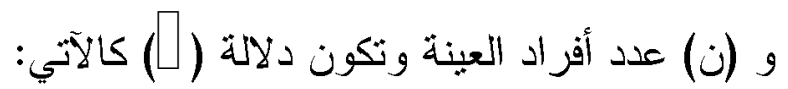

\begin{tabular}{|c|c|c|}
\hline إذا كانت & قيمة (لـ) دالة عند مسنوى دلالة (0. ·) & 1 \\
\hline إذا كانت r. & 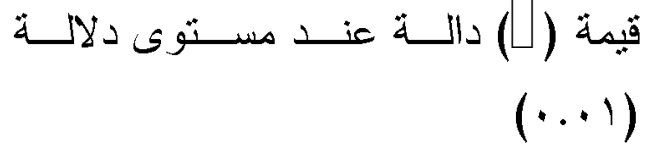 & $r$ \\
\hline إذا كانت قيمة (ل)> 9 ب. & 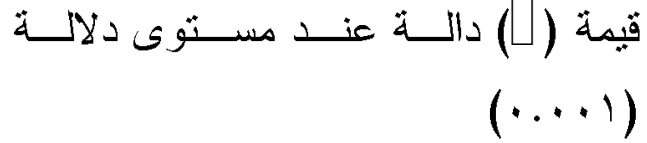 & $\mu$ \\
\hline
\end{tabular}

مناقتشة النتائج و تفسيرها:

بناء على ما سبق من إجراءات الدراسة المبدانية مـن حيـــث إعــداد الأداة المستخدمة في البحث، و اختبار صدق و ثبات الإسنبانة، ثم وصف المجثمع الذي أجريت فيه الدراسة، و الأساليب الإحصائية المستخدمة في تفسير النتائج، يُحاول الباحث التعرف على واقع تو افر أبعاد الميزة التتافسية الجامعية بكليات الجامعــة، سوف بناقش البحث النتائج من خلال استجابات أفر اد العينة على بنود الإستبانة، و يثضح ذلك كما يلي: 
متطلبات تطوير الميزة التنافسية لجامعة أسوان في ضوء الاتجاهات العالمية المعاصرة

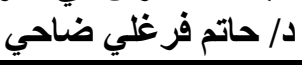

المحور الأول: الجودة المنقوقة:

جدول (s) الأوزان النسيية لاستجابات عينة النطبيق على عبار ات المحور الأول

(الجودة المتفوقة)

\begin{tabular}{|c|c|c|c|c|c|c|c|c|c|}
\hline \multirow{2}{*}{ | الترتيب } & \multirow{2}{*}{ الد الالة } & \multirow{2}{*}{ قيمة | } & \multirow{2}{*}{ الوزن } & \multicolumn{5}{|c|}{ استجابات عينة التطبيق } & \multirow{2}{*}{ رقارة } \\
\hline & & & & 1 & r & $r$ & $\varepsilon$ & 0 & \\
\hline 2 & 0.001 & 4.635826667 & 0.607778 & $Y_{1}$ & $r \varepsilon$ & 79 & $\varepsilon$ & 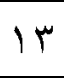 & 1 \\
\hline 7 & 0.05 & 0.447461979 & 0.501111 & $M$ & $r \leq$ & M & 10 & rV & $r$ \\
\hline 5 & 0.001 & 3.764040382 & 0.573333 & $1 \leq$ & $r \leqslant$ & 79 & $\leqslant 7$ & r. & $r$ \\
\hline 3 & 0.001 & 4.145707285 & 0.587778 & 19 & ب ب & r & $0 \lambda$ & 10 & $\varepsilon$ \\
\hline 1 & 0.001 & 4.918536368 & 0.62000 & $Y_{T}$ & ro & VT & $r v$ & 11 & 0 \\
\hline 4 & 0.001 & 4.059994527 & 0.584444 & $\zeta$. & $\leqslant$ & $\leqslant 0$ & or & YI & 1 \\
\hline 6 & 0.001 & 3.416463409 & 0.561111 & Y & T & $\leqslant 9$ & $\leqslant 0$ & $r \varepsilon$ & v \\
\hline
\end{tabular}

يتضح من الجدول السابق أن:

ا. يُلاحظ ارتفاع معظم الأوزان النسبية بالنسبة لاستجابات مجموعة الدراسة، و هذا

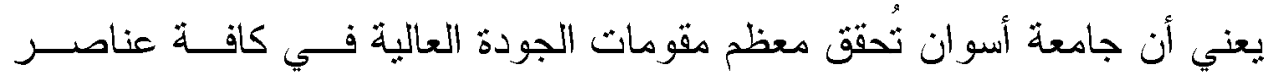
المنظومة الجامعية (المدخلات) و العمليات، و تثميز المخرجات الجامعية بكفاءة عالية و جودة مرتفعة .

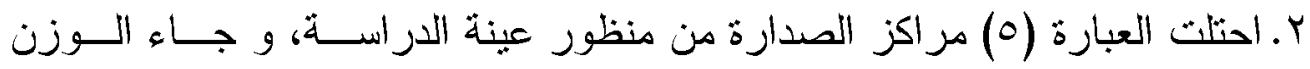

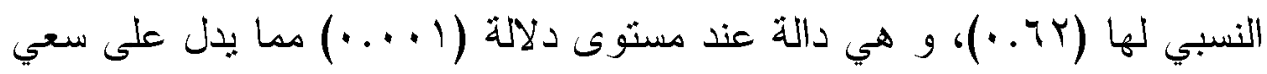
جامعة أسوان لتوفير كافة الموارد المادية و الطاقات البشرية اللخزمة لنطوير أداء الجامعة و دعم تفوقها و تميزها بهذف جذب مزيد من العملاءو المستفيدين إلبها

r. احتلت العبارثان (1) المرثبة الثانية من منظور مجموعة الدراسة، و بوزن نسبي

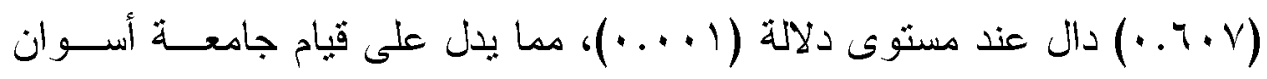

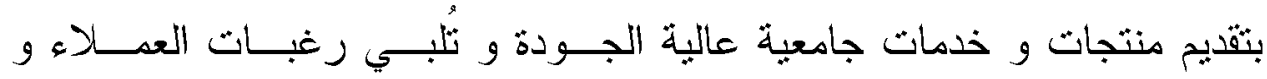


المستقبدين، و ثتخذ الجامعة بعض الآليات لتحقيق ذلك من خلال ثقديم منتجاتهــا بأسعار تتافسية ، و استخدام أماكن ( حرم جامعي) و قنوات ثوزيع مثتوعـة، و و

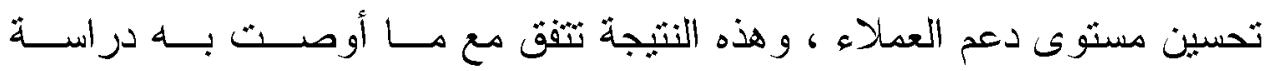

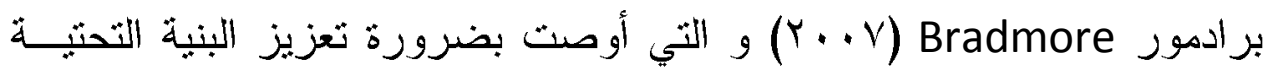
للجامعات الأستر البة و ثطوير مر اققها لاجتذاب أفضل الأساتذة و الطلاب .

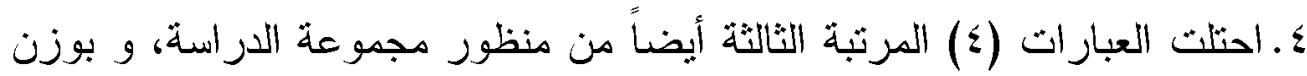

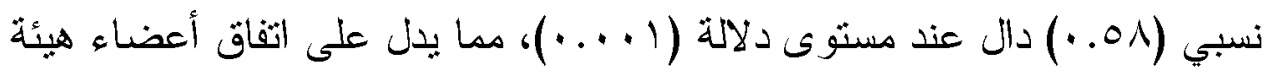

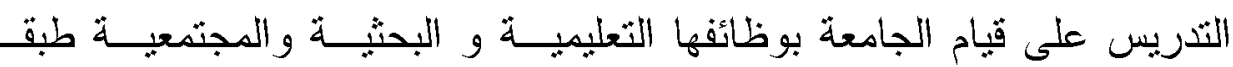

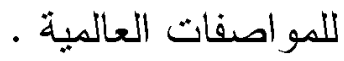
ه. احتلت العبارة (؟) المرتبة الرابعة من منظور مجموعة الدراسة، و بوزن نسبي دال عند مستوى دلالة (1 (...)، مما بدل على قيام جامعة أسوان بتقديم خدمات جامعية واسعة عبر الموقع الإكتروني للجامعة سواء لأعضاء هبئة التـدريس أو الطلاب أو للمتمع المحيط، و تثميز تلك الخدمات بالجودة العالية قياساً بخدمات الجامعات المنافسة ، و من أهم الخدمات التي يُقدمها الموقع الإلكثروني للجامعة: عرض للخطة الإستر اتيجية للجامعـة، و أهـــ الثقــارير الصــادرة عنهــا ، و البرونوكو لات التي وقعتها مع الهيئات و المؤسسات و الجامعات و مراكز البحوث العالمية، و الإحصائيات الخاصة بالجامعسـة، تعريسـف بــأهم إدارات الجامعــة، و المجلات الإككثرونية الثي تُصدرها كليات الجامعـة، و الوحسـدات و المراكـز الجامعية ذات الطابع الخاص، و خدمات متطورة لأعضـــاء هيئــة التـدريس و الطلاب و الباحثين و أحدث أخبار الجامعة و المؤثمرات التي سوف نتعقد برحاب الجامعة و أنشطة جامعة الطفل، و غير ها من الخدمات المنتوعة . 
7. احتلت العبارة (r) المرثبة الخامسة أيضاً من منظور مجموعة الدراسة، و بوزن نسبي دال عند مسنوى دلالة (1 (...) مما بدل على استخدام الجامعة أســاليب كفيلة بنطوير كفاءة المنتجات الجامعية للوصول إلــى المواصـفات العالميــة، و تحقيق مواقع منقدمة في التصنيف العالمي للجامعات ، و هذه النتيجة تتفق مع ما

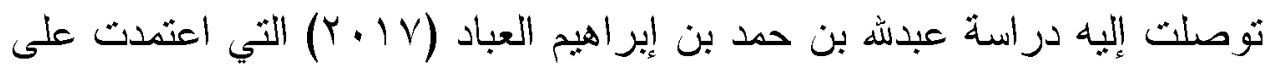
المعايير العالمبة لتصنيف الجامعات في تحقيق مزابا تتافسية مستدامة . V. احتلت العبارة (V) المرثبة السادسة من منظور مجموعة الدراسة، و بوزن نسبي دال عند مستوى( ( . ..)، وهذا يدل على اتفاق مجموعة الدراسة على ثتــيع جامعة أسوان لأعضاء هيئة التذريس على ثقديم مُبادرات للارثقاء بالخدمات الني

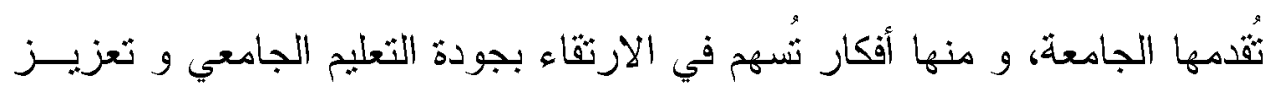
قدرات الخريجين، و بناء جسور الثواصل مع المجنمع الداخلي و الخـارجي، و تتويع مصـادر التمويل، وتطوير ثمنيات الاتصـال، و العلاقات بين أفراد المجثمـع الأكاديمي، و الأنشطة اللامنهجية . 1. فيما بنعلق بسعى الجامعة بشكل جاد لنطبيق أنظمة الاعتماد و معـايير ضــمان الجودة المحلية و العالمية جاءت العبارة (Y) في المرنبة السابعة و الأخيرة مسن منظور مجموعة الدراسة، و بوزن نسبي دال عند (0. . )، و هذا بدل على اتفاق أعضاء هيئة التدريس بالجامعة على وجود بعض أوجه القصور في نطبيق أنظمة ضمان الجودة والاعتماد بالجامعة حبث لم تحصل أية كلية على الاعنماد إلى الآن رغم ما بذلته الجامعة من جهود في إنشاء مركز لضــمان الجـودة و الاعتمــاد بالجامعة يقوم بنشر فكر و ثقافة الجودة بين كليات الجامعة . 
متطلبات تطوير الميزة التنافسية لجامعة أسوان في ضوء الاتجاهات العالمية المعاصرة

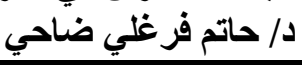

$$
\text { المحور الثاني: الإبداع المثفوق: }
$$

جدول (0) الأوزان النسيية لاستجابات عينة النطبيق على عبار ات المحور الثاني

(الإبداع المثنوق)

\begin{tabular}{|c|c|c|c|c|c|c|c|c|c|}
\hline \multirow{2}{*}{ الترتي } & \multirow[b]{2}{*}{ الدلالة } & \multirow[b]{2}{*}{ قيمة لق } & \multirow{2}{*}{ النوزن } & \multicolumn{5}{|c|}{ استجابات عينة التطبيق } & \multirow{2}{*}{ رقار } \\
\hline & & & & 1 & $r$ & r & $\varepsilon$ & 0 & \\
\hline 7 & غير & $\begin{array}{c}0.997218353 \\
-\end{array}$ & $\begin{array}{c}0.49444 \\
4\end{array}$ & $\begin{array}{l}1 \\
r\end{array}$ & 1 & $\begin{array}{l}0 \\
0\end{array}$ & $\begin{array}{l}4 \\
r\end{array}$ & Y & 1 \\
\hline 6 & 0.01 & 2.574403922 & $\begin{array}{c}0.53555 \\
6\end{array}$ & v & r & $\begin{array}{l}0 \\
9\end{array}$ & $\begin{array}{l}0 \\
\varepsilon\end{array}$ & 7 & $Y$ \\
\hline 1 & $\begin{array}{c}0.00 \\
1\end{array}$ & 5.548893784 & $\begin{array}{c}0.64888 \\
9\end{array}$ & $\begin{array}{l}r \\
1\end{array}$ & $\varepsilon$ & $\begin{array}{l}7 \\
1\end{array}$ & $\varepsilon$ & 1 & r \\
\hline 2 & $\begin{array}{c}0.00 \\
1\end{array}$ & 5.431206128 & $\begin{array}{c}0.64333 \\
3\end{array}$ & $\begin{array}{l}\text { r } \\
\text { v }\end{array}$ & 0 & r & r & 1 & $\varepsilon$ \\
\hline 4 & $\begin{array}{c}0.00 \\
1\end{array}$ & 4.313415764 & $\begin{array}{c}0.59444 \\
4\end{array}$ & $\begin{array}{l}1 \\
1\end{array}$ & r & $\begin{array}{l}4 \\
1\end{array}$ & $\xi$ & $V$ & 0 \\
\hline 5 & $\begin{array}{c}0.00 \\
1\end{array}$ & 3.214584819 & $\begin{array}{c}0.55444 \\
4\end{array}$ & r & r & $\begin{array}{l}1 \\
0\end{array}$ & $\begin{array}{l}r \\
v\end{array}$ & $\varepsilon$ & $y$ \\
\hline 3 & $\begin{array}{c}0.00 \\
1\end{array}$ & 4.739924988 & $\begin{array}{c}0.61222 \\
2\end{array}$ & $\begin{array}{l}Y \\
\varepsilon\end{array}$ & $\varepsilon$ & $\begin{array}{l}0 \\
y\end{array}$ & $\varepsilon$ & 9 & V \\
\hline
\end{tabular}

يتضح من الجدول السابق أن:

ا.يُلاحظ ارتفاع بعض الأوزان النسبية بالنسبة لاستجابات مجموعة الدراسة، و هذا

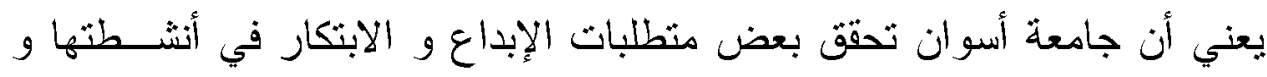

عملياتها الجامعية و لكن ثواجهها بعض التحديات و الصعوبات في تفعيل هذا البعد

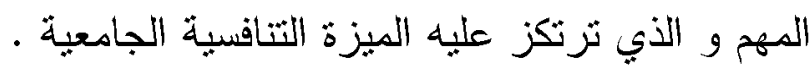


Y.احتلت العبارة (r) مركز الصدارة من منظور مجموعة الدراسة، و جاء الــوزن

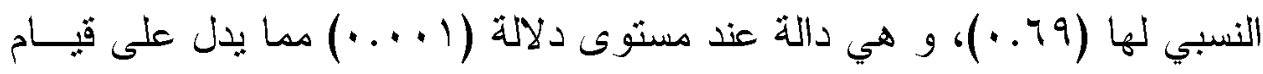

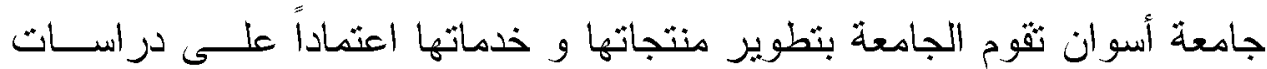
السوق الجديدة لنتكيف معها ، و لكن بختلف الباحث مع هذه النتيجة حيث هنــاك ضعف ملحوظ في نظم المعلومات بالجامعة و فيما بثعلق بالخــدمات التشــويقية بوجه خاص ن إن

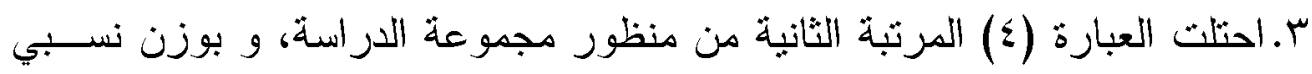

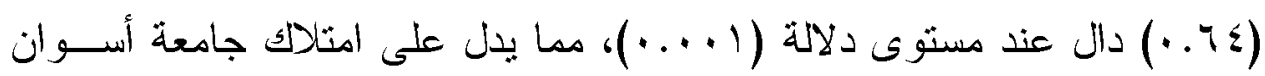

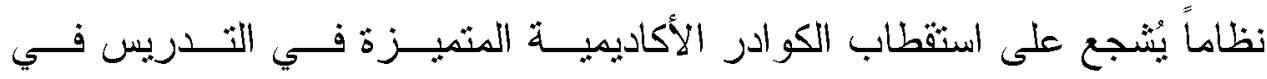

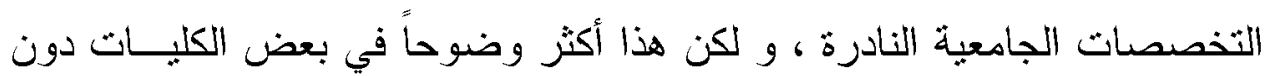

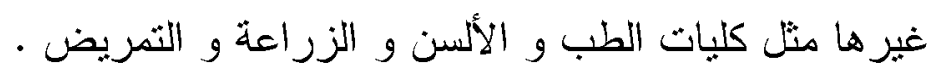

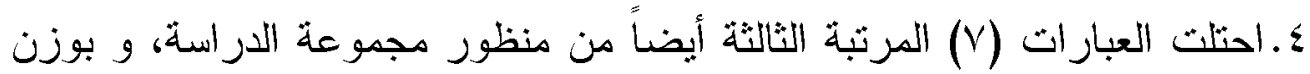

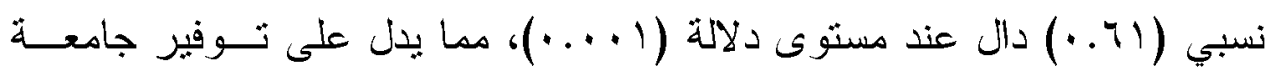

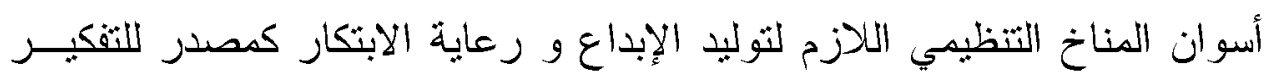
الإسنر اتيجي و ثوفير بيئة جامعية داعمة للأفكار و المشرو عات الإبنكارية .

ه.احتلت العبارة (0) المرنبة الر ابعة من منظور مجموعة الدراسة، و بوزن نســبي دال عند مستوى دلالة (1 (. ..)، مما يدل على استخدام جامعة أسوان نكنولوجيا منطورة نُساعد على نطوير و نتويع منتجاتها، لكن يختلف الباحث مع هذه النتيجة

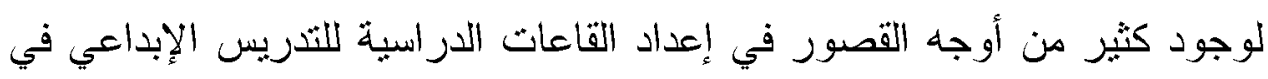

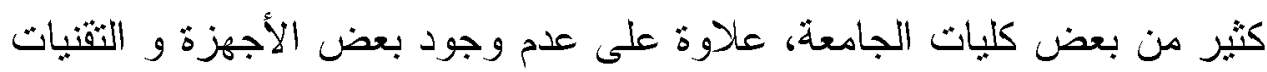

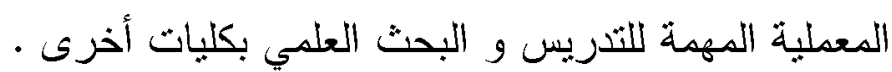

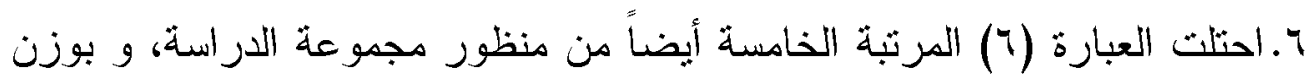
نسبي دال عند مستوى دلالة (1 (....) مما بدل على إتاحة جامعة أسوان الحرية

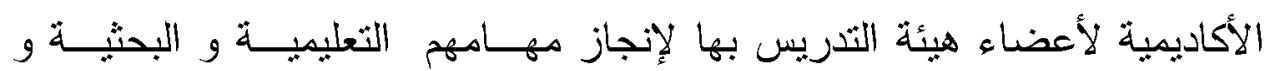

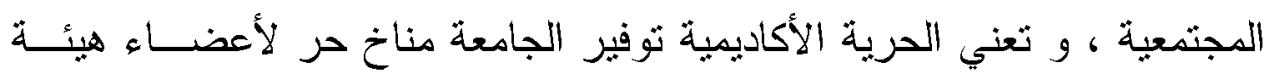


التدريس لممارسة أدوارهم بشكل من الإستقلالية دون تدخل أو تقييد من أبي جهة خارجية، و حريثهم في منابعة المعرفة العلمية و تطوير ها من خــلال البحــث و و

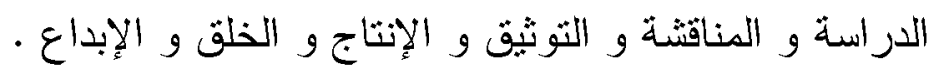

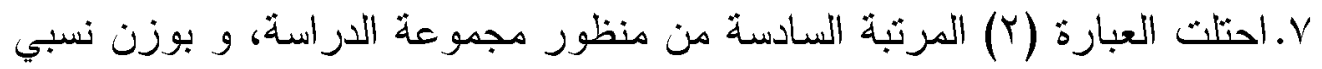

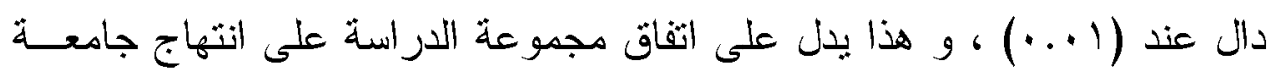

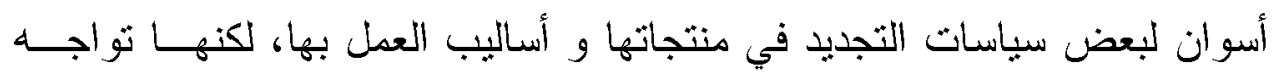
بعض الصعوبات في تفعيل هذه المفردة .

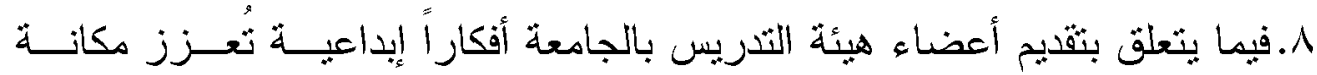
الجامعة في السوق المحلي والعالمي جاءت العبارة (1) في المرتبــة الســابعة و الأخيرة دن منظور مجموعة الدر اسة غير دال عند أبي مستوى مــن مســتويات الدلالة، و هذا يدل على ضعف اهنمام أعضاء هيئة التدريس بالجامعة بثقديم أفكار إبداعية لنطوير وظائف الجامعة الثعليمية و البحثية و المجتمعية نتيجة لعدم وجود

$$
\text { مُحفزات كافية من الجامعة . }
$$

المحور الثالث: الاستجابة المتفوقة لحاجات العملاء و المستفيدين: جدول (T) الأوزان النسبية لاستجابات عينة الثطييث على عبار ات المحور الثالث

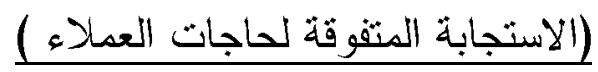

\begin{tabular}{|c|c|c|c|c|c|c|c|c|c|}
\hline \multirow{2}{*}{ الترتيب } & \multirow{2}{*}{ الدلالة } & \multirow{2}{*}{ قيمة } & \multirow{2}{*}{ النسبي } & \multicolumn{5}{|c|}{ استجابات عينة التطبيق } & \multirow{2}{*}{ رقام } \\
\hline & & & & 1 & r & $\mu$ & $\varepsilon$ & 。 & \\
\hline 5 & 0.001 & 4.765711 & 0.613333 & YI & $\varepsilon \varepsilon$ & $0 \leq$ & $\varepsilon \lambda$ & 14 & 1 \\
\hline 4 & 0.001 & 5.068333 & 0.626667 & rr & rq & $T V$ & $\leqslant 1$ & 1. & $r$ \\
\hline 2 & 0.001 & 5.431206 & 0.643333 & Tr & ru & 0\{ & ro & r. & r \\
\hline 6 & 0.001 & 4.688070 & 0.610000 & YV & rq & 7. & $r \varepsilon$ & 1. & $\varepsilon$ \\
\hline 3 & 0.001 & 5.239614 & 0.634444 & YV & $r v$ & VI & r. & 10 & 。 \\
\hline 1 & 0.001 & 5.848248 & 0.663333 & r & $\varepsilon Y$ & ror & $\leqslant V$ & 17 & 1 \\
\hline
\end{tabular}




\section{ينضح من الجدول السابق أن:}

ا ـ يُلاحظ ارتفاع الأوزان النسيية بالنسبة لاستجابات مجموعة الدراسة، و هذا يعني

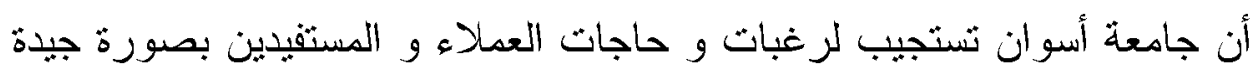

r. احتلت العبارة (آ) مركز الصدارة من منظور مجموعة الدراسة، و جاء الوزن

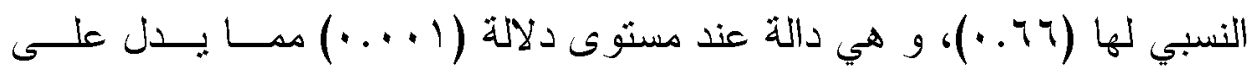

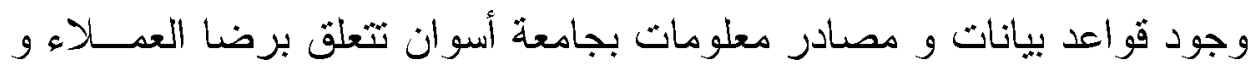

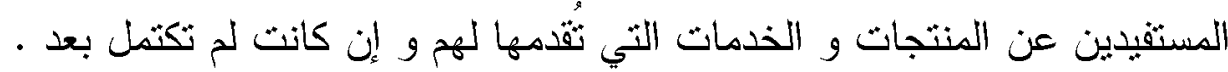

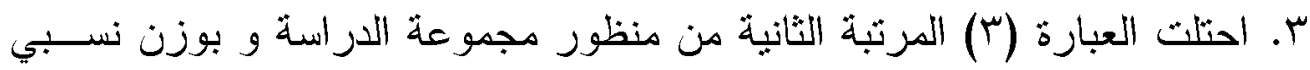
دال عند مستوى دلالة (1....)، مما بدل على اهتمام الجامعة ببحوث التسويق اللتعرف على احتياجات العملاء و سرعة إنجاز ها لالها

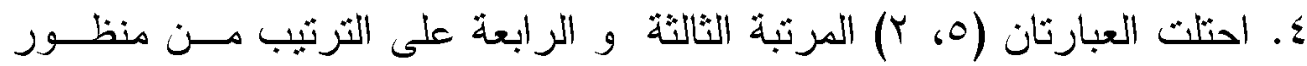

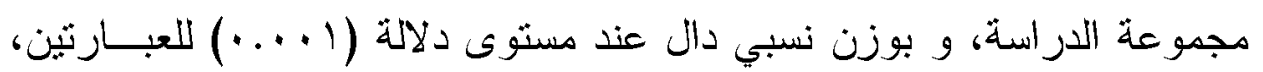

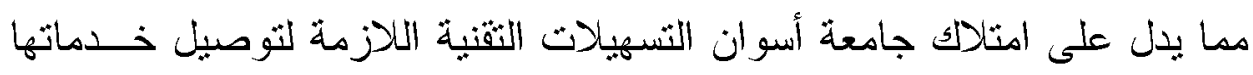

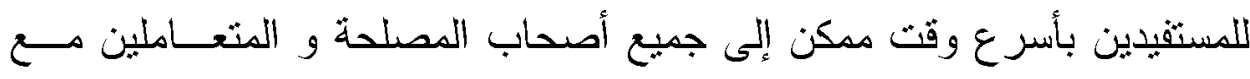
الجامعة في الوقت المناسب و المكان المناسب عبر شبكة الإنترنت و عن طريق

$$
\text { إمكانات الجوال (برنامج وانس أب). }
$$

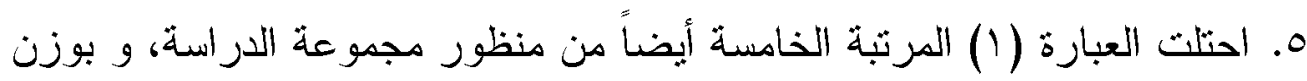

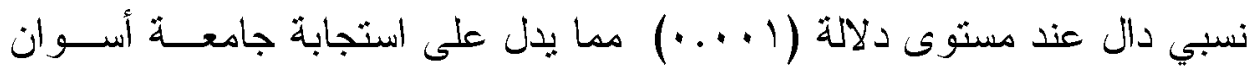

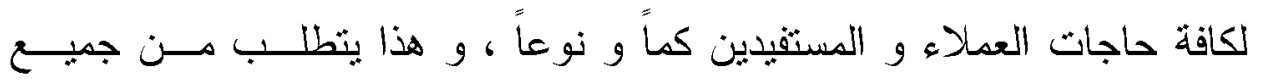

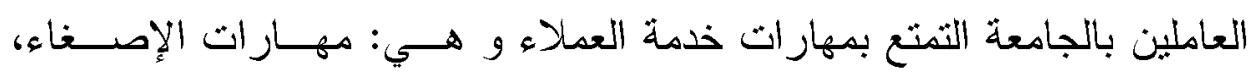
التحلي بالصبر والهاوء قدر الإمكان، مهارات التواصل الفعال، و إجادة اللغـــة الإيجايية ، و مهار ات قراءة العملاء. 
7. احتلت العبارة (ع) المرنبة السادسة من منظور مجموعة الدراسة، و بوزن نسبي دال عند (1 (...) ، و هذا بدل على اتفاق مجموعة الدراســـة علــى احتــرام الجامعة مواعبد تقديم المنتج أو الخدمة بجودة و كفاءة عالية، و هذه النتيجة تثلق

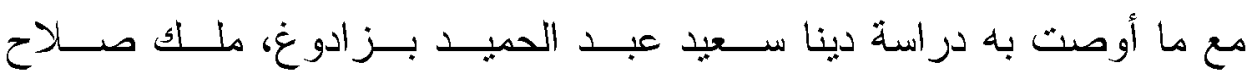

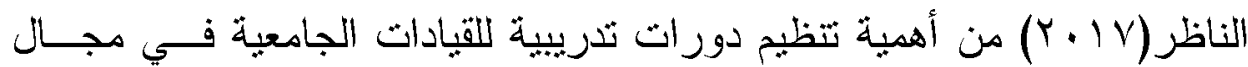
تذعبم الميزة التتافسبة الجامعية . المحور الرابع: المرونة الجامعية: جدول (V) الأوزان النسيبة لاستجابات عينة النطبيق على عبار ات المحور الرابع (المرونة الجامعبة)

\begin{tabular}{|c|c|c|c|c|c|c|c|c|c|}
\hline \multirow{2}{*}{ الترتيب } & \multirow{2}{*}{ الدلالة } & \multirow{2}{*}{ قيمة } & \multirow{2}{*}{ النسبي } & \multicolumn{5}{|c|}{ استجابات عينة التطبيق } & \multirow{2}{*}{ رقار } \\
\hline & & & & 1 & Y & $r$ & $\varepsilon$ & 0 & \\
\hline 1 & 0.001 & 4.918536 & 0.620000 & 17 & צ & $O V$ & $0 y$ & 10 & 1 \\
\hline 4 & 0.001 & 4.503431 & 0.602222 & 19 & $r 9$ & $0 \leqslant$ & or & 10 & r \\
\hline 6 & 0.001 & 4.117281 & 0.586667 & YE & $r$. & 74 & $\varepsilon \varepsilon$ & $1 \varepsilon$ & r \\
\hline 2 & 0.001 & 4.714045 & 0.611111 & $r$. & ro & ov & 01 & IV & $\varepsilon$ \\
\hline 5 & 0.001 & 4.340916 & 0.595556 & YV & r & 7. & $\varepsilon \lambda$ & 10 & 。 \\
\hline 3 & 0.001 & 4.609555 & 0.606667 & r. & \& & or & or & 17 & 7 \\
\hline
\end{tabular}

يتضح من الجدول السابق أن:

ا ـ يُلاحظ ارتفاع الأوزان النسيية بالنسبة لاستجابات مجموعة الدراسة، و هذا يعني

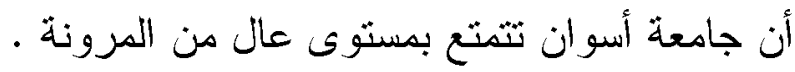
r. احتلت العبارة (1) مركز الصدارة من منظور مجموعة الدراسة، و جاء الوزن بهون

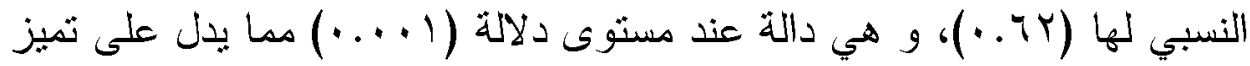

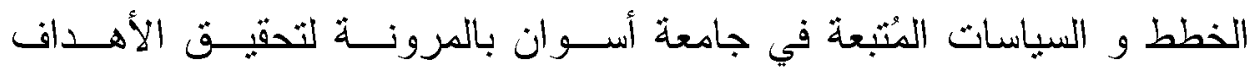
الإستر اتيجية الحالبة و المستقبلية للجامعة بسهولة . 
r. احتلت العبارة (ع) المرنبة الثانبة من منظور مجموعة الدراسة، و بوزن نســبي

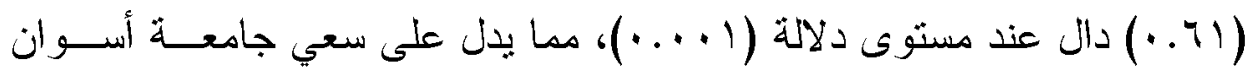

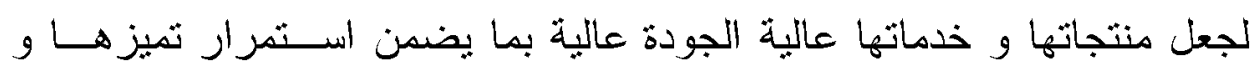
تفوقها (مرونة المنتج) و هذا ينطلب ثنبي الجامعة مداخل أكاديميــة و إداريـــة

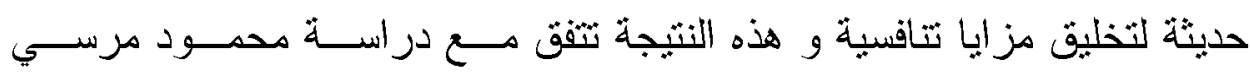

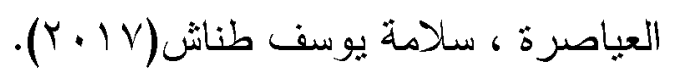

ء. احتلت العبار ات (T) المرثبة الثالثة أيضاً من منظور مجموعة الدراسة، و بوزن

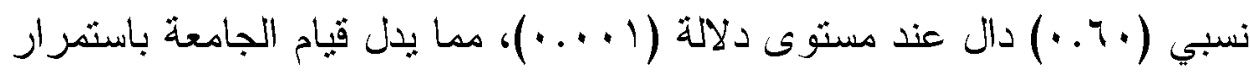
بتثيبم جودة منتجاتها و خدماتها من أجل التحسين المستمر بمرونة و اقتـدار و وله احتر افية للنأكد من تو اققها مع المو اصفات العالمية . 0. احنلت العبارة (Y) المرثبة الر ابعة من منظور مجموعة الدراسة، و بوزن نسبي

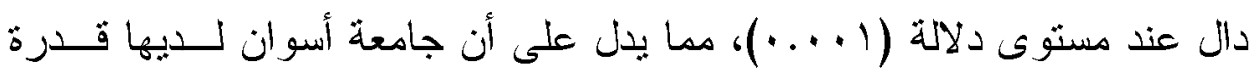

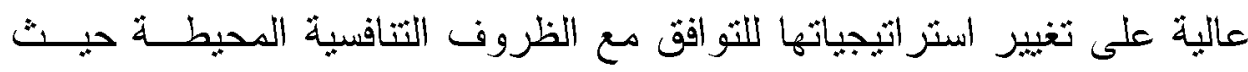

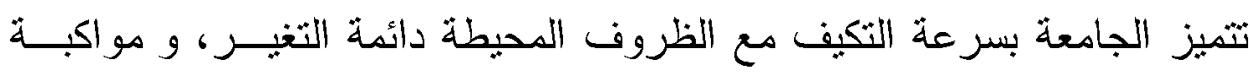
النطور و إمكانبة التغيير في العمليات الإنتاجية و ثقديم منتجات جديدة . 7. احتلت العبارة (0) المرنبة الخامسة أيضاً من منظور مجموعة الدراسة، و بوزن

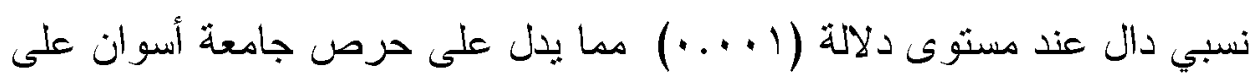

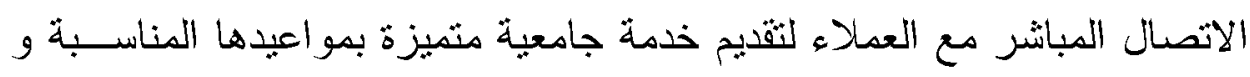

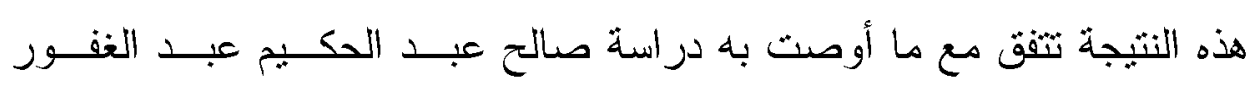
$\cdot(r .10)$

V. احتلت العبارة (r) المرنبة السادسة من منظور مجموعة الدراسة، و بوزن نسبي دال عند (1 (....)، و هذا يدل على اتفاق مجموعة الدراسة على سماح جامعــة أسوان للعملاء و المستفبدين من خدماتها بثقديم مقترحاتهم خصوصاً عبر مواقع

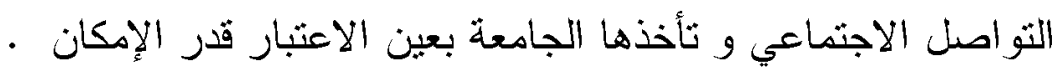


متطلبات تطوير الميزة التنافسية لجامعة أسوان في ضوء الاتجاهات العالمية المعاصرة

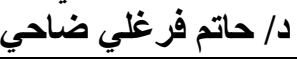

$$
\text { المحور الخامس: التكلفة و ثرشيد النققات: }
$$

جدول (入) الأوزان النسيبة لاستجابات عبنة النطييق على عبار ات المحور

الخامس (التكلفة و ترشيد النفقات )

\begin{tabular}{|c|c|c|c|c|c|c|c|c|c|}
\hline \multirow{2}{*}{ الترتيب } & \multirow{2}{*}{ الدلالة } & \multirow{2}{*}{ قيمة } & \multirow{2}{*}{ النوزن } & \multicolumn{5}{|c|}{ استجابات عينة التطبيق } & \multirow{2}{*}{ رقار } \\
\hline & & & & 1 & r & $r$ & $\varepsilon$ & 0 & \\
\hline 3 & 0.001 & 4.817007 & 0.615556 & Tr & r & 09 & $\varepsilon r$ & $Y \leq$ & 1 \\
\hline 6 & 0.001 & 4.791404 & 0.614444 & r) & $\mu$ & 7. & 0. & 11 & r \\
\hline 2 & 0.001 & 5.166 & 0.631111 & 11 & $\mu$ & కo & 07 & rr & $r$ \\
\hline 5 & 0.001 & 4.503431 & 0.602222 & r & ro & ov & $\leqslant V$ & 11 & $\varepsilon$ \\
\hline 1 & 0.001 & 5.431206 & 0.643333 & r) & 19 & $7 V$ & $\leqslant 7$ & YV & 0 \\
\hline 4 & 0.001 & 4.449719 & 0.600000 & Y & צ & 7. & $\varepsilon \varepsilon$ & 11 & 1 \\
\hline
\end{tabular}

يتضح من الجدول السابق أن:

A. يُلاحظ ارتفاع الأوزان النسيية بالنسبة لاستجابات مجموعة الدراسة، و هذا بعني أن جامعة أسوان تتمتع بمستوى عـال مـن ترشـبـ النفقـات و التكــاليف و

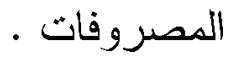

9. احتلت العبارة (0) مركز الصدارة من منظور مجموعة الدراسة، و جاء الوزن

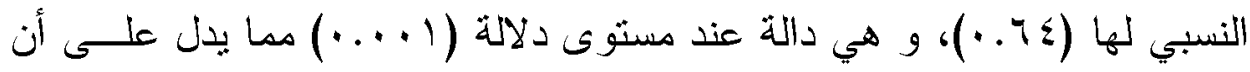
تخفيض التكاليف و نرشيد النققات و حسن اســتخدام المــوارد مــن الأهــداف

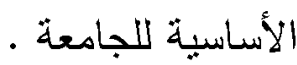

• 1 ـ احتلت العبارة (r) المرتبة الثانية من منظور مجموعة الدراســة، و بــوزن نسبي (rا. ·) دال عند مستوى دلالة (1 (...)، مما يدل على ســي جامعــة 
أسوان للاحتفاظ بالكفاءات من أعضاء هيئة التدريس و العاملين لتخفيض حجـ التكاليف حيث كليات الجامعة أغلبها جديدة و تشترط على أعضاء هيئة التدريس المعينين بها عدم الثقدم بطلبات نقل قبل مرور عشر سنوات . 11 ـ احتلث العبار ات (r) المرثبة الثالثة أيضـاً من منظور مجموعة الدراســة، و

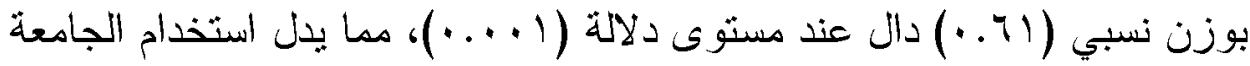
ثقنيات حديثة مرنة في إنجاز العطليات التشغيلية والإدارية بالجامعة بتكلفة أقـلـل من خلال ثوظيف إمكانات الإدارة الإلكترونية بالجامعة . r ا. احتلت العبارة (ب) المرتبة الرابعة من منظور مجموعة الدراسة، و بــوزن نسبي دال عند مستوى دلالة (1 (...)، مما بدل على أن جامعة أسوان تُحــاول استخدام أساليب حديثة في تقديم المنتجات و الخدمات عالية الجودة بأقل تكلفــة مُككنة . r ا. احتلت العبارة (乏) المرثبة الخامسة أيضاً من منظور مجموعة الدراسـة، و بوزن نسبي دال عند مستوى دلالة (1 (...) مما بذل على حسرص جامعـة أسوان على تخفيض الخدمات التكميلية، و استثندار مواردهــــا المالبــة بصــورة اقتصادية رشيدة ، و هذه النتيجة تثفق مع ما أوصت به دراسة محمــد عبـدله محدد عبدله (9 1 ب ب) من ألبات لرفع القيمة المضافة لمنتجات و خدمات الجامعة باستخدام مدخل سلسلة القيمة . ـ ا. احتلت العبارة (Y) المرثبة السادسة من منظور مجموعة الدراسة، و بــوزن نسبي دال عند (1 (...)، و هذا يدل على اتفاق مجموعة الدراسة على استخدام الجامعة تثنيات حديثة مرنة في إنجاز العمليات النشغيلية و الإداريسـة بالجامعـة

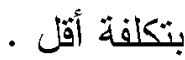


متطلبات تطوير الميزة التنافسية لجامعة أسوان في ضوء الاتجاهات العالمية المعاصرة

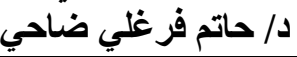

المحور السادس: الثميز و الثفوق على المناقسين

جدول (9) الأوزان النسيبة لاستجابات عبنة النطبيق على عبار ات المحور

السادس (الثميز و الثفوق على المنافسين)

\begin{tabular}{|c|c|c|c|c|c|c|c|c|c|}
\hline \multirow{2}{*}{ الترتيب } & \multirow{2}{*}{ 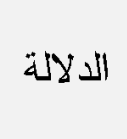 } & \multirow{2}{*}{ قيمة } & \multirow{2}{*}{ النسبي } & \multicolumn{5}{|c|}{ استجابات عينة التطبيق } & \multirow{2}{*}{ رقلم رق } \\
\hline & & & & 1 & r & r & $\varepsilon$ & 0 & \\
\hline 7 & 0.001 & 3.513909 & 0.564444 & r & ri & $\varepsilon r$ & 0. & 17 & 1 \\
\hline 0 & 0.001 & 3.702732 & 0.571111 & rq & rq & $0 \leqslant$ & $\leqslant 0$ & 14 & r \\
\hline 1 & 0.001 & 4.714045 & 0.611111 & r. & rᄉ & $0 \leqslant$ & $\leqslant \wedge$ & r. & r \\
\hline$\varepsilon$ & 0.001 & 4.059995 & 0.584444 & Yo & rq & 01 & \& & iv & $\varepsilon$ \\
\hline r & 0.001 & 4.145707 & 0.587778 & rq & 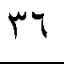 & 01 & $\leqslant 0$ & 19 & 0 \\
\hline v & 0.001 & 3.001814 & 0.547778 & rะ & 4 & ov & rq & IY & 1 \\
\hline r & 0.001 & 4.503431 & 0.602222 & ro & r. & 70 & rᄉ & rr & V \\
\hline
\end{tabular}

يثضح من الجدول السابق أن:

1. يُلاحظ ارتفاع الأوزان النسبية بالنسبة لاستجابات مجموعة الدراسة، و هــــا بعني أن جامعة أسوان تثمتع بمستوى مقبول من التميز و التفوق على الجامعات

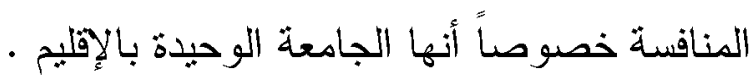

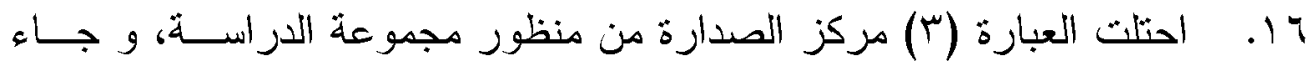

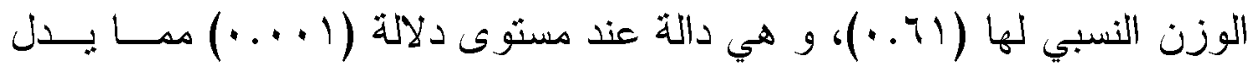
على اعتماد جامعة أسوان على نظم معلومات إداريــة نشــــح بالتتســيق بــين

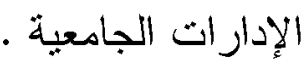

IV . احتلث العبارة (V) المرتبة الثانية من منظور مجموعة الدراســة، و بــوزن

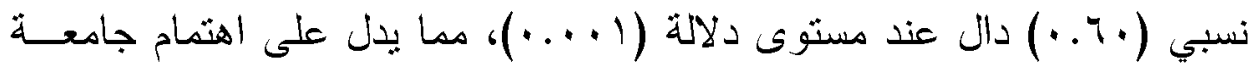

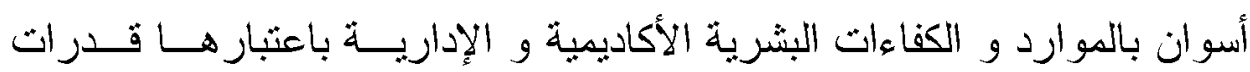
اسنر اتيجية لدى الجامعة غير قابلة للتقليد و المُحاكاة . 


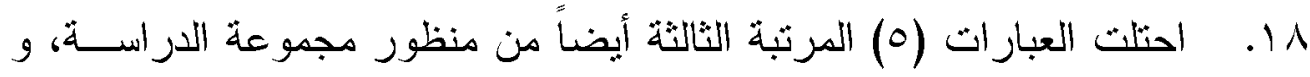

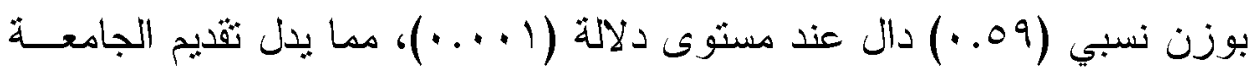
بر امج تعليمية في تخصصات علمية نادرة تفي باحتياجات سوق العهـلـ دائمــة - التغير

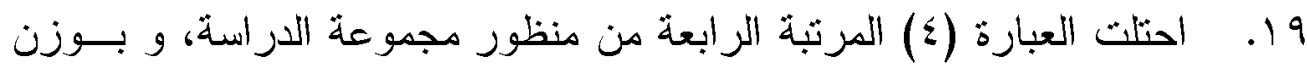

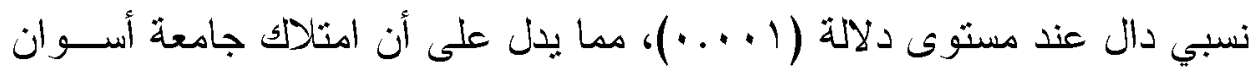
نظام رقابة بتضمن فحص و تثييم كفاءة العمليات الإدارية و الأكاديمية بالجامعة.

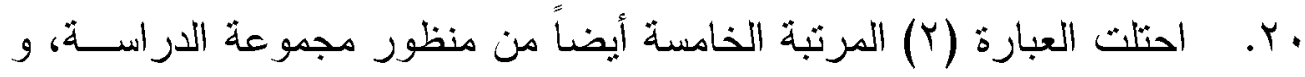
بوزن نسبي دال عند مستوى دلالة (1 (...) مما يدل على استقصاء الجامعـة

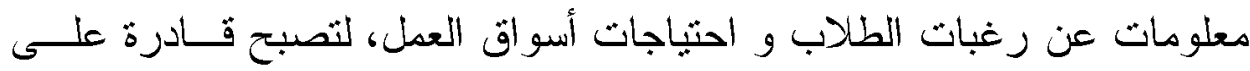
تكوين كوادر بشرية تُلائم عصر اقتصاد المعرفة المدعوم بنكنولوجيا المعلومات ، كو ادر تمثلك مهار ات وظيفية و فنية و إنتاجية و إثر افية و إحتر افية. ا r. احتلث العبارة (1) المرتبة السادسة من منظور مجموعة الدراسة، و بــوزن

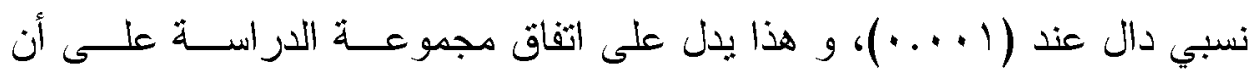

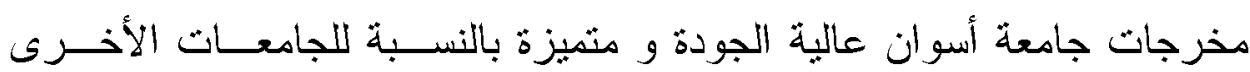

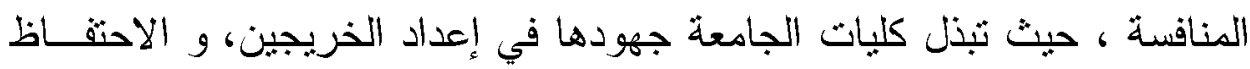

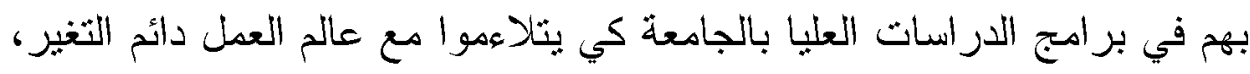

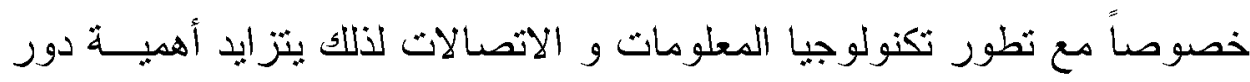

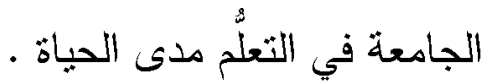

r. احتلت العبارة (ب) المرثبة السابعة من منظور مجموعة الاراسة، و بوزن نسبي دال عند (1 (...)، و هذا يدل على اتفاق مجموعة الدراسة على ثركيز الجامعة على ثقديم نوع معين من المنتجات الجامعية الني لا ثقدمها الجامعات المنافسة ،

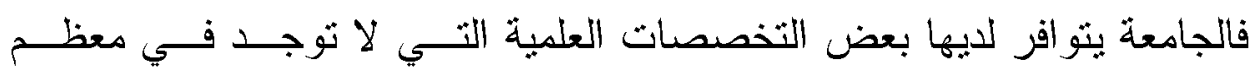


الجامعات المصرية منل كلية تكنولوجيا المصايد و الأسماك و معهـــ الثــئون

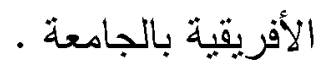

مناقشة نتائج الار اسة المبدانية: ا ـ تُحقق جامعة أسوان ميزة الجودة العالبة في كافة عناصر المنظومــــة الجامعيـة

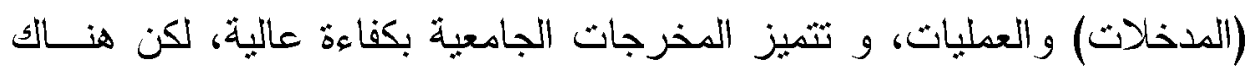
بعض وجود بعض أوجه القصور في تطبيق أنظمة ضمان الجــودة و الاعنمـاد

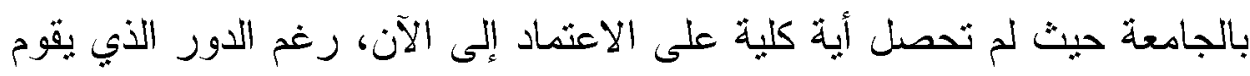

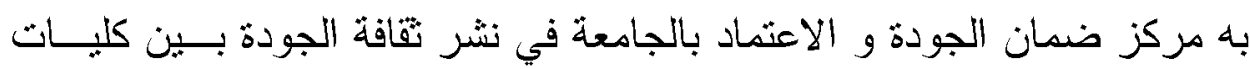
الجامعة . برة

Y. تُحقق جامعة أسوان ميزة الإبداع و الابتكار في أنتطنها و عملياتها الجامعية، و

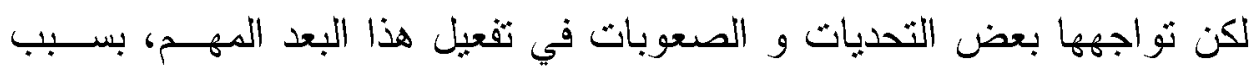

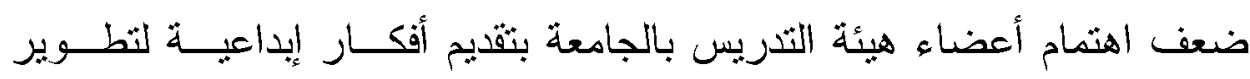

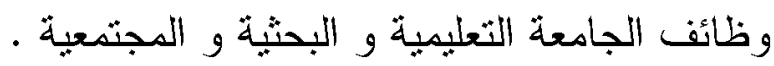

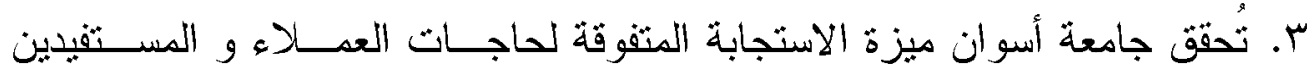
بصورة جيدة بالاعتماد على التقنيات الحديثة لتوصيل خدماتها للمستفيدين بأسرع

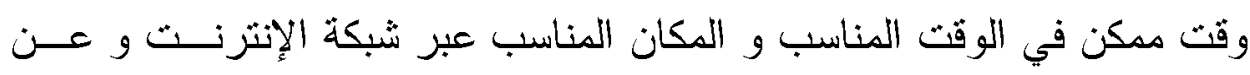

$$
\text { طريق إمكانات الجوال (برنامج واتس أب). }
$$

ـ. تُحقق جامعة أسوان ميزة المرونة بصورة جيدة من خلال تغيير اســتراتبجياتها

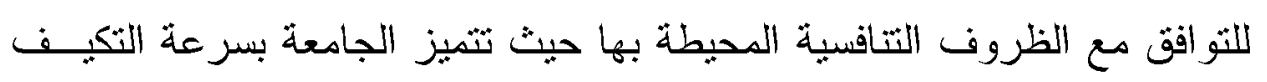
مع الظروف المحيطة دائمة التغير •

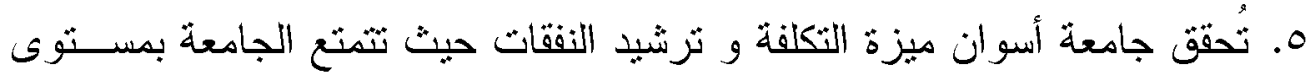

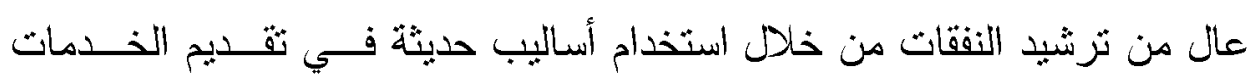

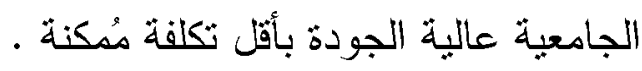
7. تُحقق جامعة أسوان ميزة التمبز و التفوق على المنافسين حيث نتمثع الجامعسـة

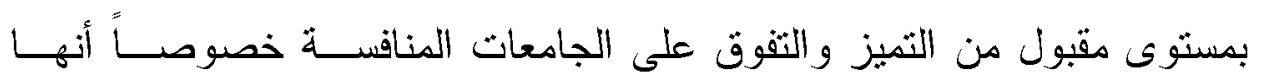


الجامعة الوحيدة بالإقليم التي تقدم بر امج تعليمبة في تخصصـات علمية مُتمبــزة تفي باحتياجات أسواق العمل دائمة التغير ل

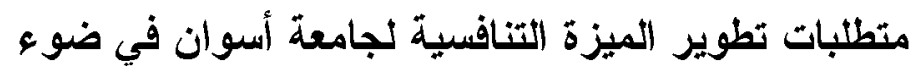

الاتجاهات العالمية المعاصرة: تصور مقترح

تسعى الجامعات في ظل بيئة شديدة التنافسية إلي كسب ميزة نتافسية ثميز ها عن غيرها، و ذلك من خلال إضـافة قبمة للعمبل ، و تحقيق الثمبـز عـن طريــق

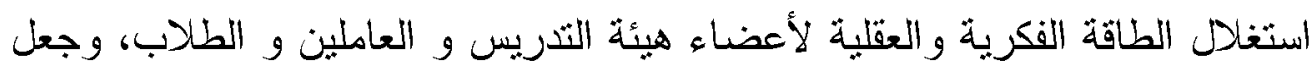

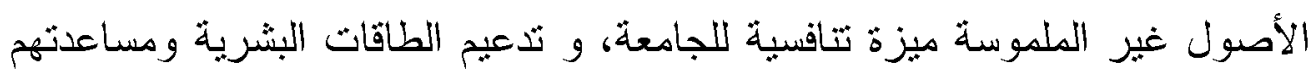
على اكتثاف امكانياتهم المحتملة، و لكي تتمكن الجامعات مــن تعزيــز المزايــا

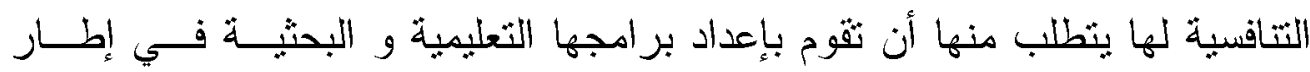
استر اتيجيات الميزة التتافسية . فأه فلسفة التصور المقترح و أهدافه :

في ظل ما بشهده العالم في القرن الحادي و العثرين من تصـاعد المنافســة

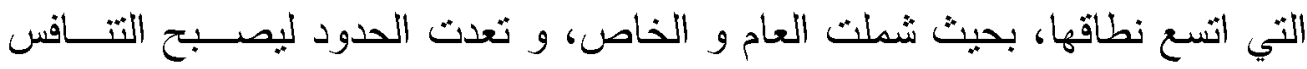

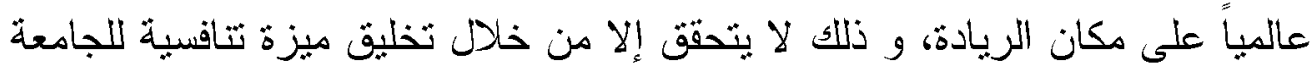

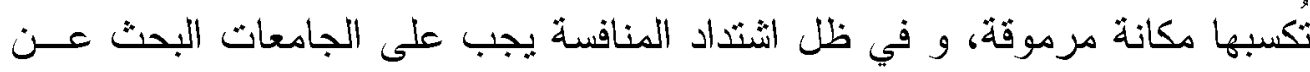

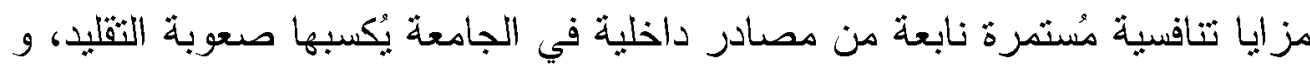
هذا المصدر يتمثل في الموارد البشرية القادرة على التفكير و الإبداع و التحسين من

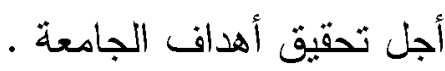
و تتعرض جامعات اليوم للعديد من التغيرات بالغة التأثير فــي سباسـنها و

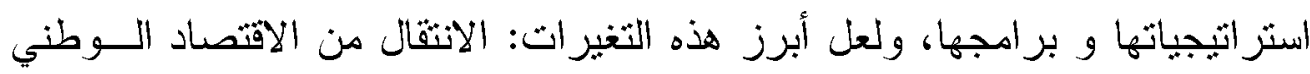
إلى الاقتصاد العالمي، و دن مجتمع المعلومات إلى مجتمع المعرفة، و من التبعيــة

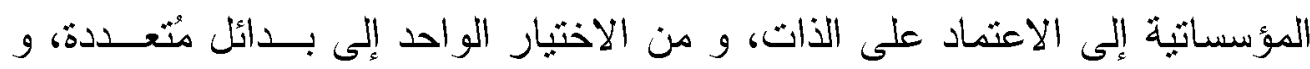

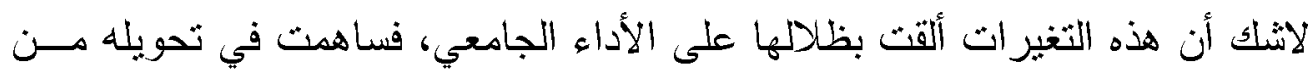




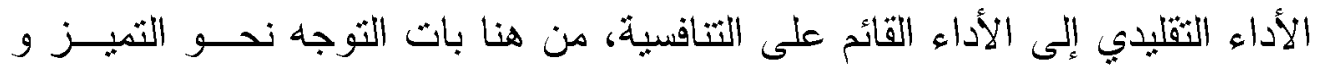

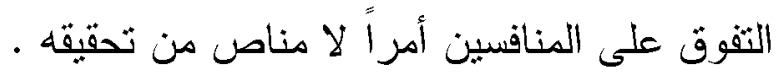
و لكي تحقق جامعة أسوان القدرة التتافسية لابد من قيامها بدورها الحقبة الهي في بناء نظام جامعي بنسم بالتتوع و التزابط يُساعدها في تحقيق التميز فيما بينها في

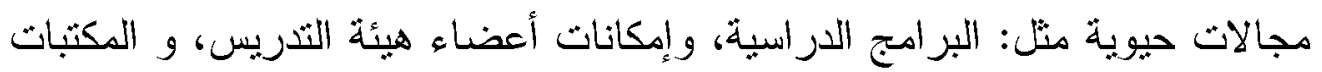
التي تملكها، و القاعات الدر اسبة و التجهيزات البحثية، و تشهيلات التذريب العملـي

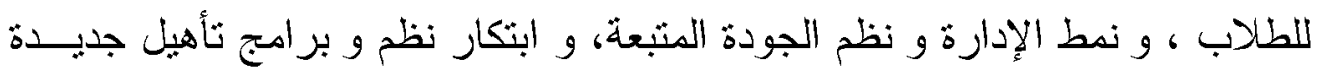

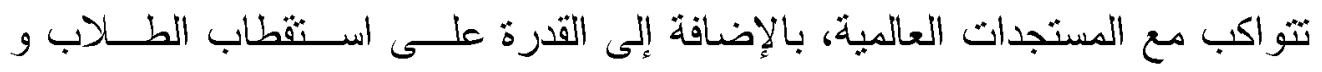

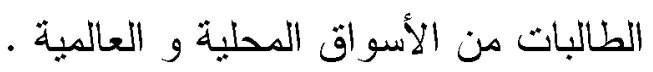
و تستند فلسفة التصور المقترح على أسس و مبادئ ثُر اعي طبيعة العصر

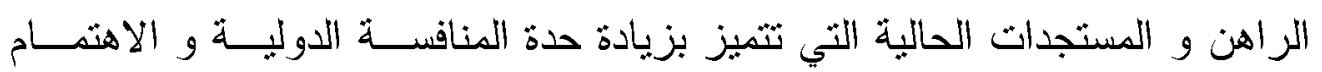

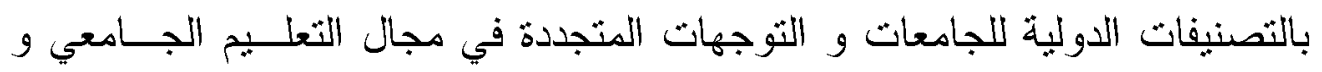
احتباجاته و متطلباته المتتوعة من العمل التعاوني و المتجدد، و الاتجاهات العالميــة

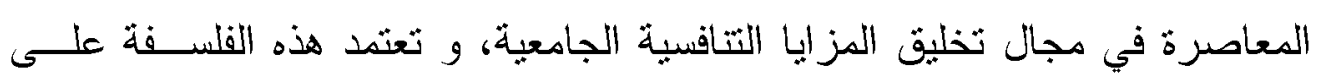

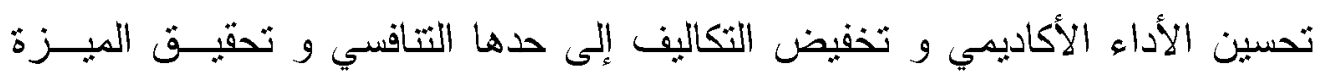

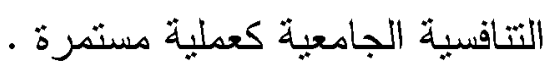

أهداف التصور المقترح > هذا التصور بمثابة دعوة إلى التطوير و التفاعل مع المستجدات و عدم انتظــار

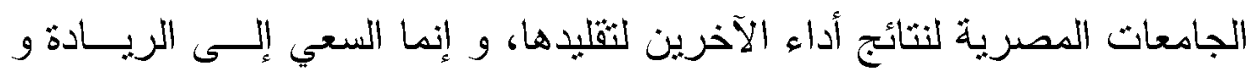
التَّعرف على كل ما هو جديد لتحقيق الأفضلية.

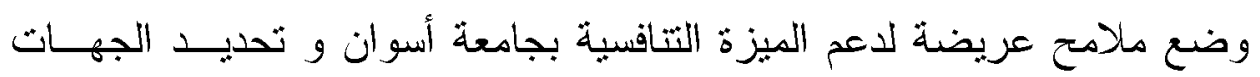
المشاركة في هذا الاعم. تقديم بعض الآليات التي يُمكن أن تعتمد عليها الجامعات المصرية في دعم الميزة التتافسية الجامعية. 
لا مُساعدة متخذي القزار لرسم خطط مستقبلية لدعم الميزة التتافسية الجامعية بُغية الحصول على مر اكز مثتمدة في تصنيف الجامعات العالمية . منطلقات التصور المقترح: ا.تعليم القرن الحادى والعشرين هو حجر الأساس للتنافسية، فالتحولات الجوهزيــة فى الإقتصاد تنطلب سياسات خلاقة لإيجاد ثواصل بين التعليم و التنافسية، فنظام

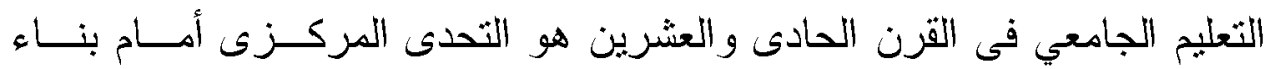
القدر ات التنافسية للاول . r.إن مستقبل نجاح أي منظمة لبس امثداد لنجاحات الماضي، و رغم أن الخبرات و واته النجاحات السابقة لا يُمكن إنكارها في المستقبل، إلا أن التتافسية الجديــدة هـي وهي محاولة لصنع و تشكيل المستقبل، و ليس مجرد الانثقال إلبه للبحث عن مكان فيه. ب.تُعد المبزة التنافسية بمثابة السلاح الرئيسي لمواجهة تحديات السوق، من خــلهل قيام المنظمة بتنمية قدرثها على نليية احثياجات الزبائن في المسنقبل، عن طريث مقرتها الجوهرية التي تُكنها من التكيف للفرص سربعة التغير ، كما تُعد معيارًا

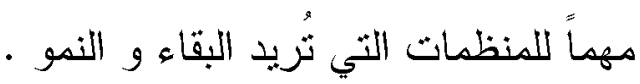

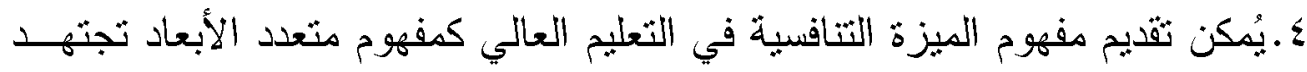
الجامعات في تحقيقه، بهدف احتلال موقع مُتمبز في التصنيف الدولى للجامعات، فالتتافسبة هي حالة ذهنية تدفع إلى التفكير في كيفية نطوير الجامعات لموقعها في • السوق

ه. تعثمد الميزة التتاقيبة للجامعات على أن الجودة النوعية الثي تثطلب جـودة أداء

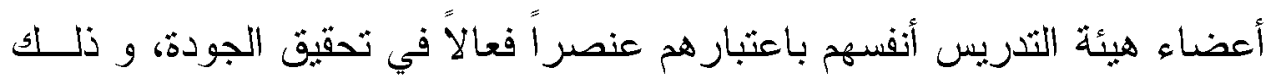

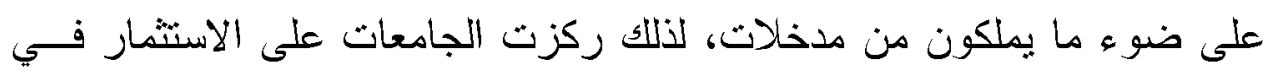

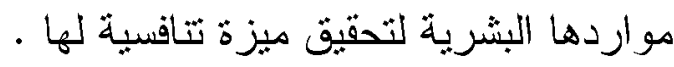

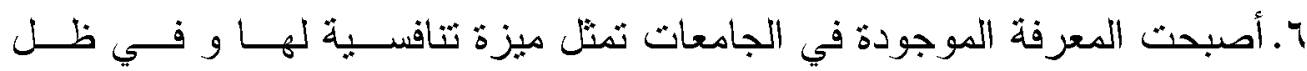
محدوبة الموارد المادية للجامعات وانخفاض الدعم الخارجي أصبحت الجامعات 
تعثمد على مواردها الداخلية و الخارجية من أجل تعزيز ميزاتها التنافسبة بهدف تحقيق الارثقاء في مستو اها التعليمي •

\section{أسس و مرتكزات التصور المقترح:}

يستتد تحقيق الميزة التنافسية الجامعية لجامعة أسوان على مجموعة ركائز أهمها: ا. تبني الجامعة رؤية استراتيجية لتحقيق الميزة التنافسية: و هو منطلب مُهم لتحقيق

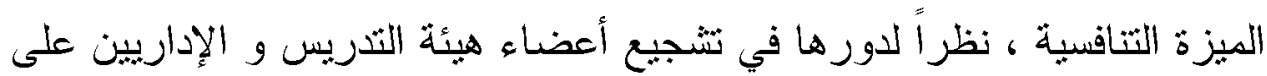
تحقيق أفضل أداء جامعي بأقل تكلفة ممكنة . r. نوفير البنية التحنية اللازمة لتحقيق الميزة التتافسية: يحتاج تحقيق الميزة التتافسية بنية تكنولوجية و مباني ومرافق مجهزة بأحدث الثقنيات ، و ثو افر قو اعد بيانات

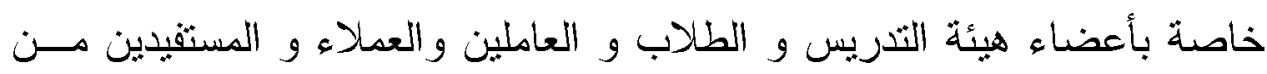
الخدمات الجامعية، و هذا كله بُنتبح فرص لتحسين الأداء الجامعي المؤسسي .

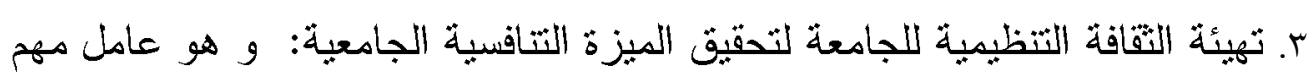
لنجاح الجامعة في تخليق مزايا تتافسية، لدورها في إكساب أعضاء هيئة التدريس المكونات الثقافية للميزة التنافسية . ع. توفير الموارد المادية الملائمة لنحقيق الميزة التنافسية: بحتاج تحقبــق الميـزة التتافسية مزيد من الموارد المادية (موارد مالية لتوفير رواتب و مكافأت أعضاء

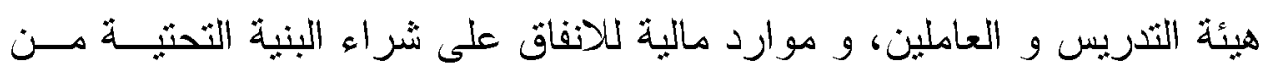

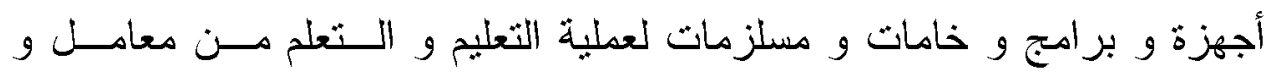

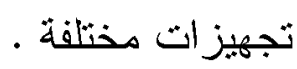
ه. توفير الموارد البشرية الملائمة لتحقيق الميزة التنافسية: و هي العوامل الأهم في تهي

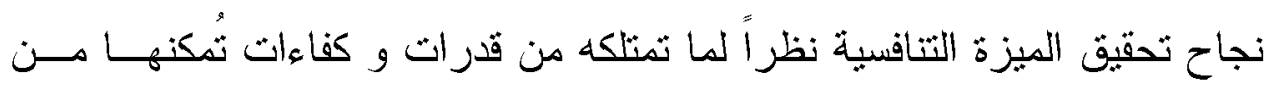
توظيف و اسنثمار الموارد المالية في تحقيق الثميز و التفوق • 
7. الثركيز على المستفيدين (العملاء): إن احتياجات العمـلاء و المسـتفيدين مــن

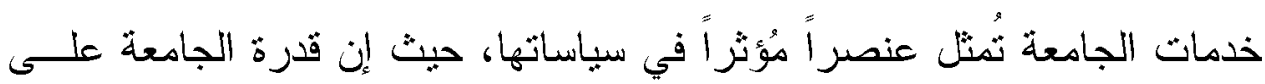
تلبية هذه الاحتياجات و تقديم خدمات ذات جودة عالية .

v. التحسين المستمر للعمليات الجامعية: إن الوصول إلى مخرجات ذات جودة عالية إنما يعتمد في الأساس على التحسين المستمر للعمليات الجامعية، من خلال تشجيع المبادرات المبدعة، و تنمية المعارف و الكفاءات لدى جميع عناصر المنظومسـة الجامعية، كما بعتمد التحسين المستمر على قياس رضا المستفيدين .

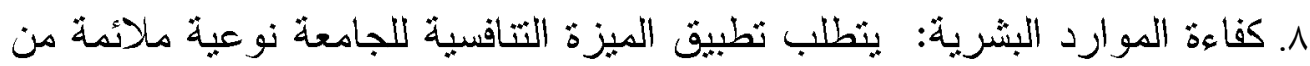
الموارد البثرية تكون ذات كفاءة عالية و لايها القدرة على تحمل مسئولية اتخــاذ

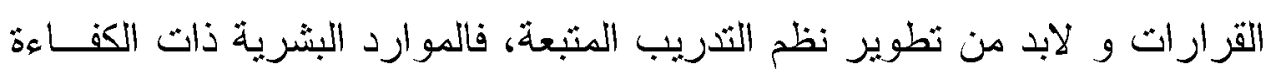

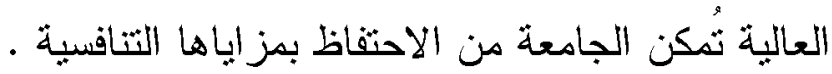

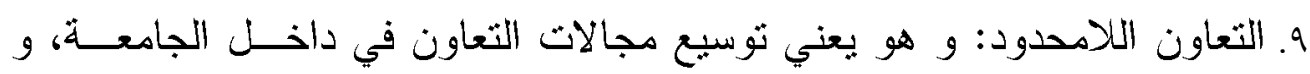

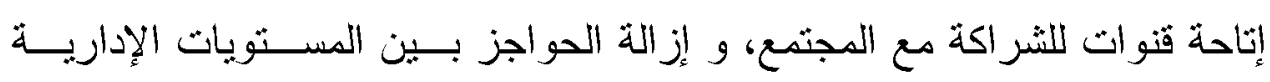
بالجامعة ضمانات تحقيق التصور المقترح: ا. الثركيز على أركان بناء الميزة التناقسية: و هي (الكفاءة و الجودة و الإبــداع و

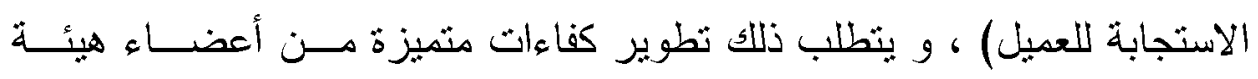

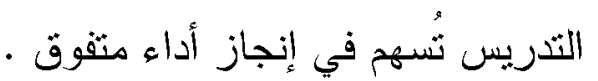

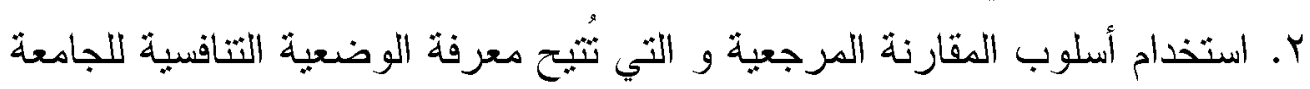

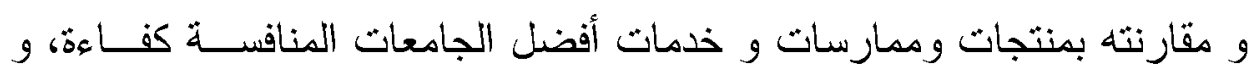

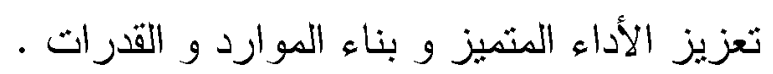
ب. البقضة الإستر اتيجية: و هي عملية منظمة تثضدن البحث و التحليل و الاتثة ولـاء

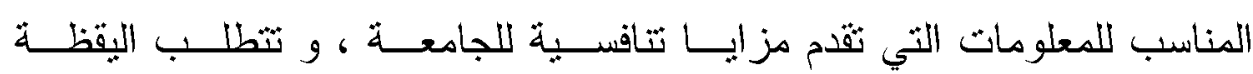

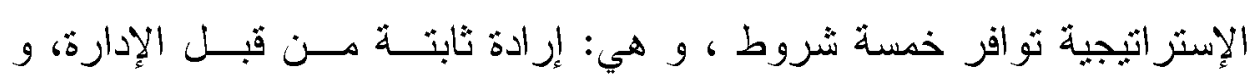


الاتصـال الداخلى الجيد ، و التحكم في الوقت ، و الحد الأدنـى مــن الهياكـل التظظيمية . ـ. الذكاء الاقتصادي: و هو امتداد للبقظة الإستراتيجية من أجل استعمال هجـومي للمعلومة بهذف تعزيز و استمر ارية الميزة التنافسية، و ذلك من خلال بناء معرفة هونة

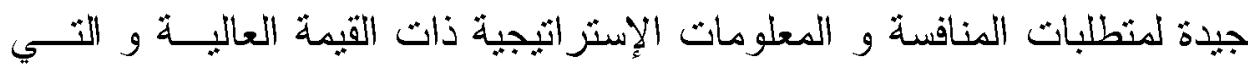
تسهم في تعزيز تتافسية الجامعة . ه. الاستمر ار المنظم لعمليتي التحسين و التعلم: في ظل النغير الديناميكي في البيئة أصبح من السهولة تلاشي الميزة النتافسية أما عن طريق التقلبد أو التفوق عليها

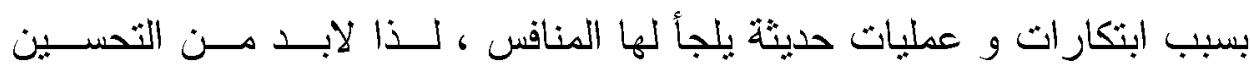
المستمر للكفاءة و الجودة و التحديث و الاستجابة للعميل .

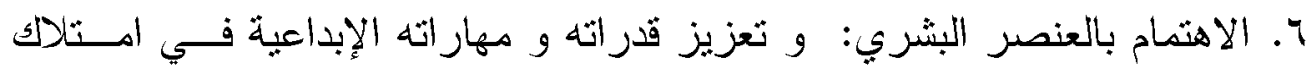

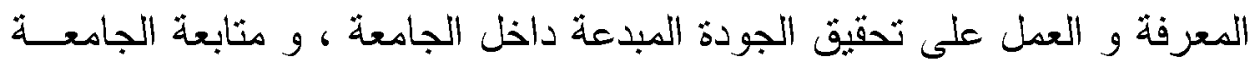
لمدى جدوى مواردها المادية و البشرية لضمان اســثمر ارية الريــادة والســـث التنافسي، و تجديد سياساتها التنافسية و نوجههاتها الإسنر اتيجية لاستدامة المزابا التتافسية بها V. زيادة القدرة الإبداعية: يُشكل التفكير الإبداعي أسلوباً حديثًا لحـلـل المشــكلات و

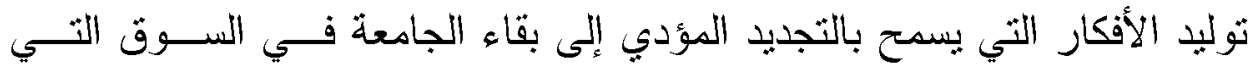
تتصف بشدة المنافسة، و تتمية التفكير الإبداعي لا ثقتصر على تتمية مهــار ات

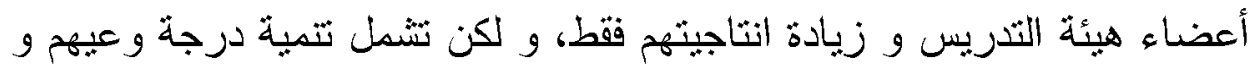
تتمية إدر اكهم و توسيع مداركه و تصور اتهم و تتمية خبالهم . A. تتويع المنتجات الجامعية: ليس بإمكان الجامعة الاعتماد على إنتاج نوع واحد من المنتجات و الخدات الجامعية و لمدة طويلة، خاصة في زمن يثميز بقصر دورة لئه حياة المنتج. 9. جذب عملاء جدد و تعزيز و لائهم: نحتاج الجامعة إلى ضمان تسويق منتجاتها، و مع انتداد المنافسة يُمكن أن ثفثقد الجامعة عملائها في أي لحظة و بمنعها ذلك 
متطلبات تطوير الميزة التتافسية لجامعة أسوان في ضوء الاتجاهات العالمية المعاصرة

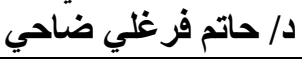

من الاستمرار في نشاطاتها و أعمالها، و تحتاج الجامعة إلى زبائن جدد في كل

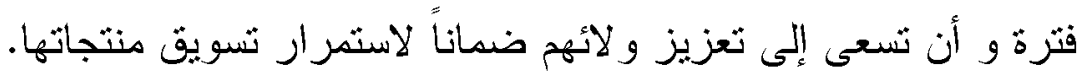
متطلبات تطوير المبزة التنافسية لجامعة أسوان في ضوء ولهير الاتجاهات العالمية

\section{المعاصرة}

المنطلب الأول: تطوير رأس المال البثري

تشجيع أعضاء هبئة التدريس و العاملين على المشاركة في البـــرامج التدريبيــة

$$
\text { داخل و خارج الجامعة. }
$$

تزويد أعضاء هيئة التدريس بالمعلومات المتجدة أول بأول باســتخدام ثقنبـات

$$
\text { مثطورة (الإنترنت و الجوال). }
$$

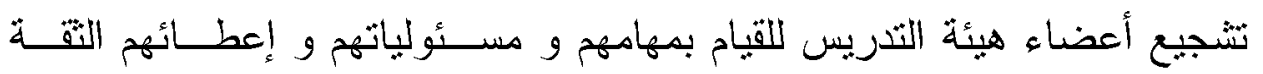

$$
\text { •بأنفسهم }
$$

تشجيع التعاون و العمل الجماعي بين أعضاء هيئة التربيس و تتمية الاتصالات

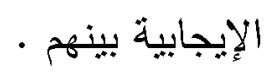

> اسنثمار الجامعة للقدرات المتمبزة من أعضاء هبئة التدريس و العاملين و إتاحة

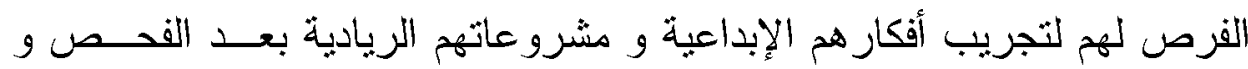

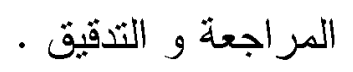
تُثابع الجاهعة الكفاءات المتميزة بغرض جذبها و استقطابها لتستفيد منها الجاهعة في تطويز مزاباها التنافسية و الحفاظ عليها بمختلف آساليب الجذب و الاستبقاء

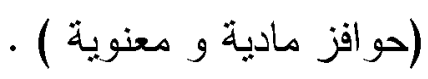
إقامة المؤتمرات العلمبة المحلية و الدولية لاستثمار طاقات أعضاء هيئة التدريس و إبراز الكفاءات . تسعى الجامعة لملء الثو اغر الوظيفبة بأعضاء هيئة تدريس مُؤهلين تأهيلاً عالباً و بمو اصفات عالمبة . 
متطلبات تطوير الميزة التتافسية لجامعة أسوان في ضوء الاتجاهات العالمية المعاصرة

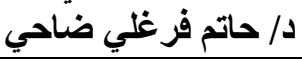

\section{المتطلب الثاني: تطوير النظل و القواعد الإدارية الحاكمة}

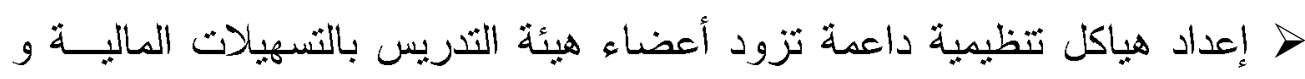

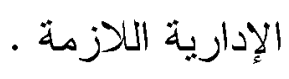

> تغيير الثقافة النتظيمبة بالجامعة للتكيف مع المنافسة الحادة القائمة على المعرفة .

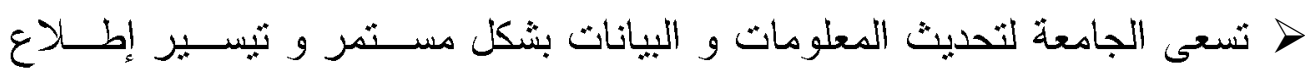

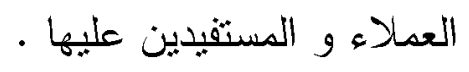
بناء ثقافة تتظيمبة إيجابية تُجبع الإبداع و الإبتكار و تكافئ الجامعة المتمبـزين

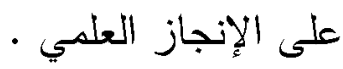
تتبنى الجامعة مو اصفات و معايير ضمان الجودة بشكل صارم في جميع كلياتها

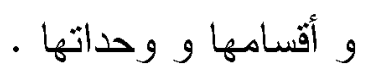

إ إسراع الجامعة في توظيف تكنولوجيا المعلومات و الاتصالات فـي عملياتهــا التعليمية و البحثية و المجنمعية. انتقاء الجامعة للعاملين فيها بعناية فائقة و تأهيلهم و تدريبهم بشكل جيد لضـــــان حل المشكلات الإدارية.

> سعى الجامعة لتأصيل نقافة الاستفادة من نتائج البحث العلمية في تحسين وظائف الجامعة . الجمان. > إنثاء مر اكز خدمة المجنمع بالجامعة للقيام بدورات لتدريب أفراد المجنمع على

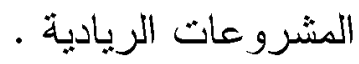
المتطلب الثالث: المرونة الإستراتيجية للجامعة (مرونة الموارد - مرونة القدرات):

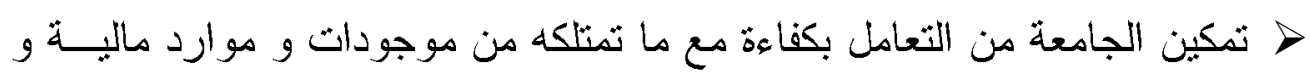
مادية و بثرية و معرفية و مهار ات بما يمنحها قدرة عالية على تفعيل الخيارات من مونه

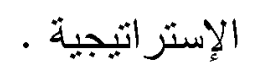
> استفادة الجامعة من الموارد المتاحة و الأكثر فعالية لتليية احتباجات عملائهــا و المستفبدين منها . 
متطلبات تطوير الميزة التنافسية لجامعة أسوان في ضوء الاتجاهات العالمية المعاصرة

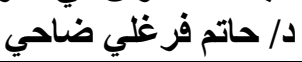

استخلال كافة الفرص السوقية بالملائمة مع قدرات الجامعة و إمكاناتها الحالية و المستقبلية .

خا تبني الجامعة سباسات و اضحة لتطوير علاقاتهـا و ســـتهـا لـدى أصــحاب المصلحة و المستفبدين من خدماتها >ا اهتمام الجامعة بمقترحات العملاء و المستفبدين في ثقديم خدمات جامعية جديــدة و إجراء تحسينات عليها.

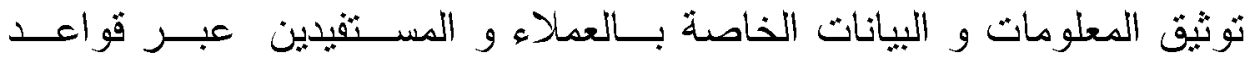
معلوماث و بيانات منطورة . خا سعي الجامعة لجذب المزيد من العملاء و المستفيدين و ثقتح المجال للاتصــال

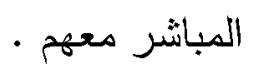
التعاون مع جامعات عالمية و مؤسسات أكاديمية و بحثية مرموقة فــي العـالم لتحسين قدرثها التنافسية . > امتلاك الجامعة علاقات طيبة مع مختلف المؤسسات المجتمعية و الإنتاجية فـي

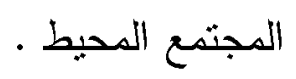

المتطلب الرابع: تأسيس مجتمع المعرفة بالجامعة

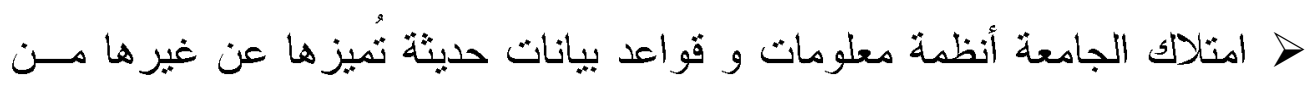

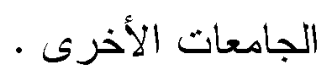

> امتلاك مكتبة مركزية يتو افر بها أحدث الكتب و الدورات و المراجـع العلميــة

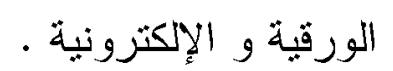

> امتلاك الجامعة انشتر اكات مع العديد من قو اعد الييانات التي ثُقدم خدمات علمية و بحنية . مبنا > امتلاك الجامعة موقع إلكتروني يُشبع احتياجــات أعضـــاء هيئسة التـدريس و

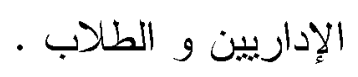
> إتاحة إصدارت الجامعة على البوابة الإكترونية و تحويل المجلات الورقية إلى مجلات إلكترونية . 


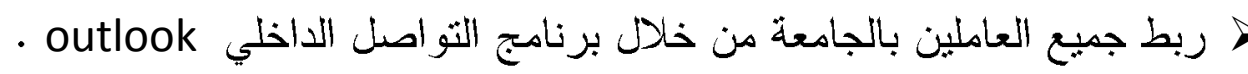

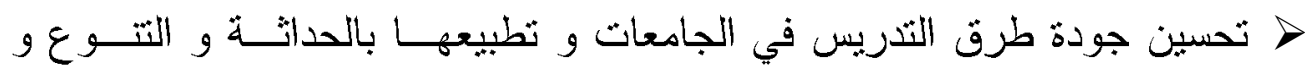
الاعتماد على طرق التعلم الذاتي والتعاوني و العصف الذهني بالإضــافة إلــى بـى

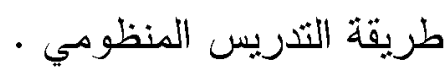

المتطلب الخامس: تطوير الوظيفة البحثبة للجامعة تبني الجامعة فكرة الريادة البحثية في نثاطات البحث العلمي بالجامعة لتحقيـقة

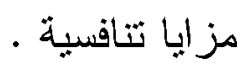
تفعيل الخطط و الإستر اتيجيات البحنية للجامعة و التسويق الجيد لها بين كليـات الجامعة ، و تتجيع أعضاء هيئة التدريس على نشر بحوثهم في دوريات علمية

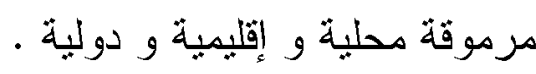
تشجيع أعضاء هيئة التذريس على البحث العلمي و الإبداع و التأليف و الترجمة دونة

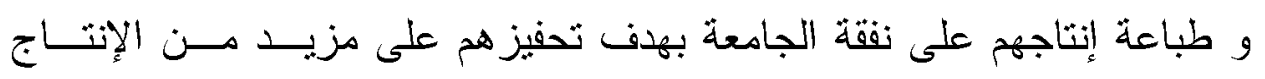
العلمي. إقامة مر اكز للثميز على مسنوى عال من الجودة و قادرة على مثابعة الثطــور

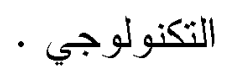
> اعثماد الجامعة لضمانات لحقوق الملكية الفكرية و النشر المعرفي .

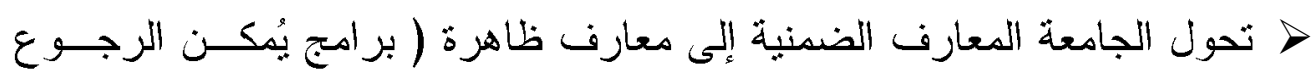

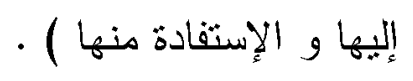
المنطلب السادس: السعي نحو التميز و التفوق على المنافسين

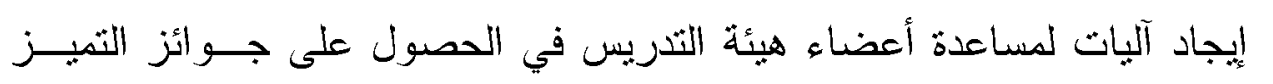
العلمي و براءات الاختر اع و المنح > احتضان الجامعة للأفكار و المثروعات المبدعة و المنميزة و تقديم الدعم المادي

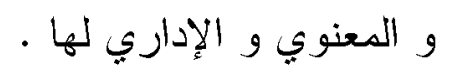


متطلبات تطوير الميزة التتافسية لجامعة أسوان في ضوء الاتجاهات العالمية المعاصرة

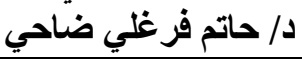

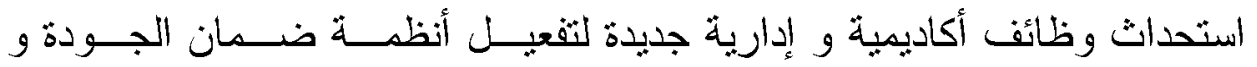
الاعتماد مثل نائب رئبس الجامعة للجودة و الاعتماد و وكيل الكليــة لضـــــان

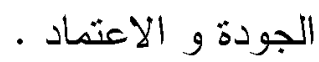

> استخدام الجامعة صيغ و نماذج جامعية حديثة ترثقي بالأداء الجـامعي مثــل :

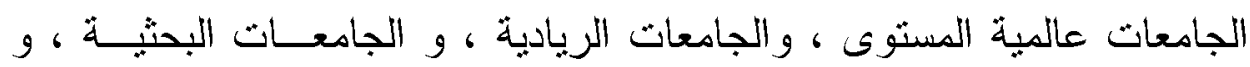
الجامعات المنتجة و الجامعات الاسنثمارية . المتطلب السابع: تطوير الوظيفة التعليمية للجامعة تصميم بر امج تعليمية في التخصصات النادرة و التي تدعم مزايا ثتافسية تنافسية عالمية للجامعة . إعداد بر امج أكاديمية و أنثطة نعليمية دولية لاستهطاب الطلاب و الباحثين مسن

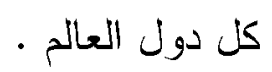
عقد اتفاقيات الثر اكة مع الجامعات العالمبة من خلال الثبادل الطلابي . وضع إجر اءاث تحفيزية للطلاب و الباحثين من خلال منح الدراسة و التـدريب بالجامعات الإقليمبة و العالمية

> مر اعاة البعد المستقبلي في تناول المقرارات المختلفة بمعنى أن كل مقرر ينبغي

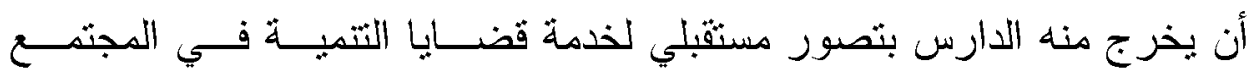

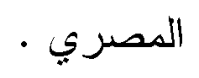

المتطلب الثامن: تطوير الوظيفة المجتمعية للجامعة :

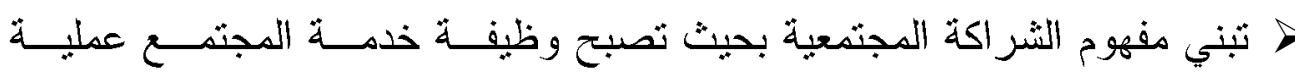

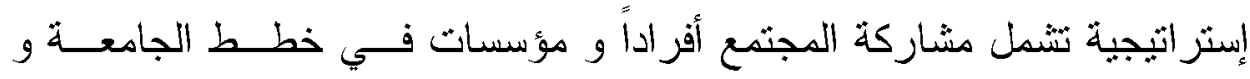

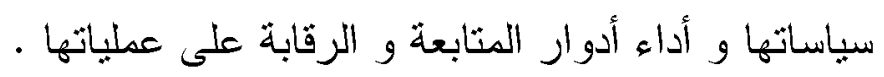
استحداث إدارة جامعية لخدمة العملاء و المستقبدين تستهدف إستطلاع آراء كافة

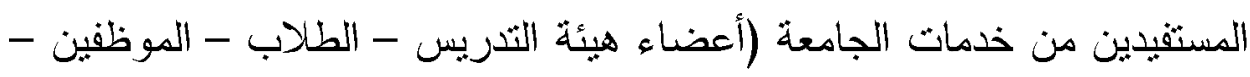

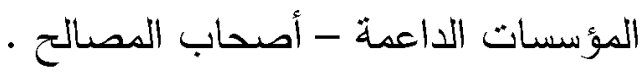


متطلبات تطوير الميزة التتافسية لجامعة أسوان في ضوء الاتجاهات العالمية المعاصرة

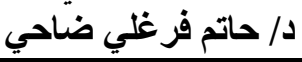

> تشهيل حصول العملاء و المستفبدين على خدمات الجامعة و سرعة الاســنجابة

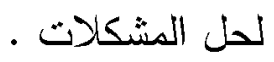
> التواصل مع مؤسسات المجتمع المدني لتحسين مهار ات الطــلاب و الخــريجين

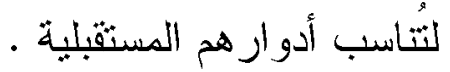
إ إنشاء إدارة مسثقلة للعلاقات التقافية و التعاون الدولي تسثقطب الطلاب الو افدين

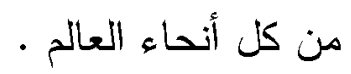
امتلاك الجامعة كادر أكاديمي و إداري لديه القدرة على حل المشكلات المرثبطة

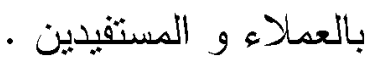

المتطلب التاسع : التركيز على الطلاب باعثبار هم أهم عملاء الجامعة

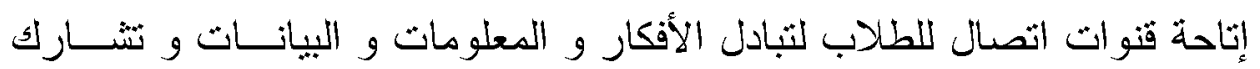
المعرفة . المهن

در اسة الاحتياجات المعرفية للطلاب في ضوء مستجدات العصر و تغير ظروف

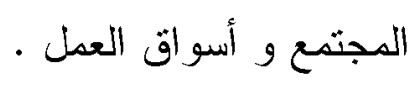

عقد دورات تدريبية للطلاب للمساهمة في تدعيم المزايا التتافسـية للجامعــة و الدعايا لمنتجاتها و خدماتها . تشجيع الانفتاح المعرفي و إكساب الطلاب مهـار ات الـتعلم الـذاتي و الــنعلم

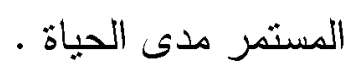
> جذب الطلاب الخريجين لمواصلة الدراسات العليا بالجامعة مع الاحتفاظ بو لائهم

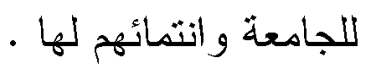
تعزيز الجامعة للقيم و الأخلاق لدى الطلاب للوصول إلى الفضــائل الحســنة و

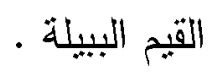
إناحة أجهزة حاسوب عالية المواصفات و خدمات الإنترنت بثقنيـة مثقدمــة و بسر عاث عالية . > توفير الجامعة لعدد من المنح و الإعفاءات من الرسوم للارجات العلمية المختلفة. 
> تفهم الجامعة الظرون المالية للطلاب و يكون لديها نظام إقراض و إعفاء شفاف و عادل بين الطلاب .

> اختبار الطلاب للالتحاق بالجامعة بناء على قدرات و مهار ات و معارث الطلاب عالبة الثميز تلبية احتياجات الطلاب باعتبار هم هدف الجامعة و سر بقائها و اسـثمرار ها و

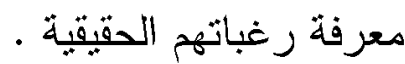
وجود نظام للإرشاد التربوي و الأكاديمي و المهني داخل الكليات للمساهمة في حل المشكلات الطلابية . المنطلب العاشر : التكيف مع مستجدات اقتصاد المعرفة السعى الجاد نحو استثمار مزابا اقتصاد المعرفة باعتبار ها وسائل ناجحة لتحقيق

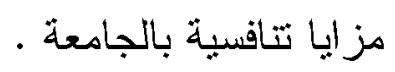

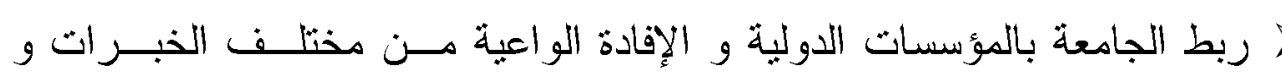

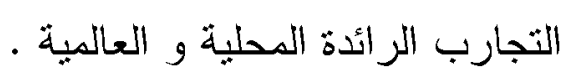

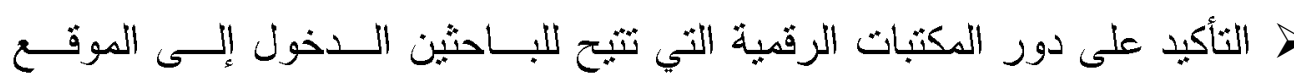

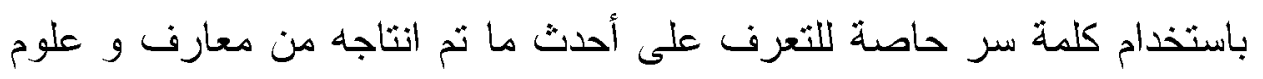

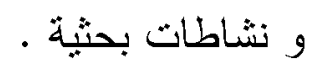

> الاهنمام بتطبيقات تكنولوجيا المعلومات و الاتصالات مثل : شبكة الإنترنــــ -

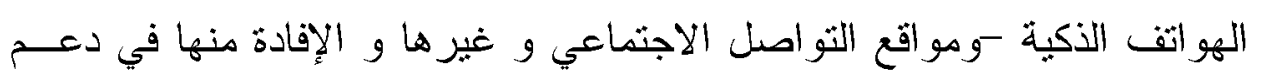
عمليات التعليم و التعلم بالجامعة . استفطاب كفاءات بشرية أكادمية و إدارية عالي المهارة تشنطيع تحقيق مزيد من المز ايا التتافسية .

سعي القيادات الجامعية إلى جلب أحدث الوسائل التكنولوجيـــة المحققــة لميــزة التتاقسية .

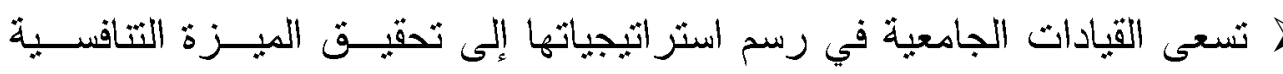
الجامعية . 


\section{توصيات البحث :}

ا. وضع خطة للاستفادة من تجارب الجامعات المرموقة و نوجيه الاهنــام نحسـو

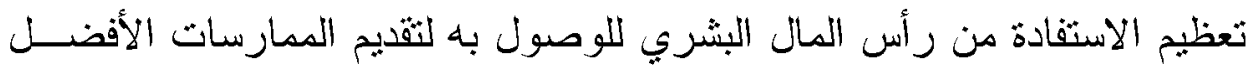

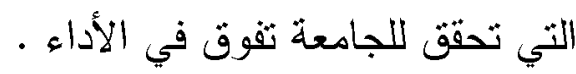

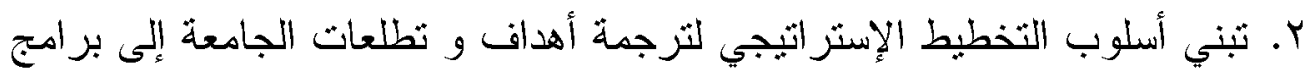

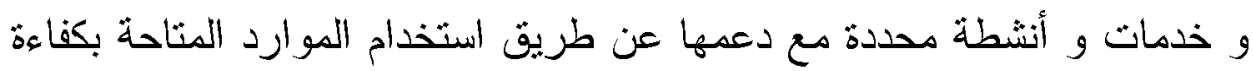
و فعالية .

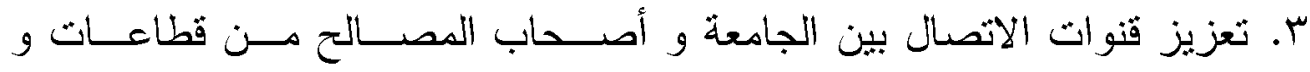

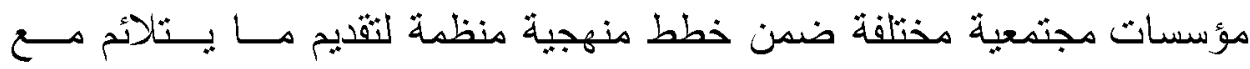

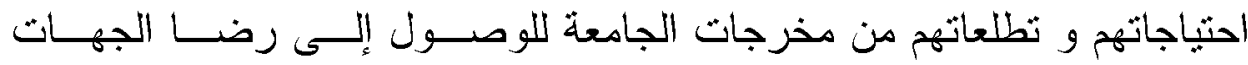

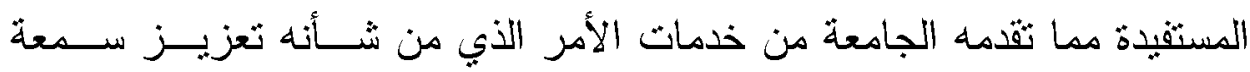

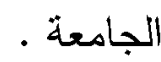

ـ. إنشاء دوقع للتو اصل الاجتماعي لأعضاء هيئة التدريس لتبادل الخبرة و المعرفة

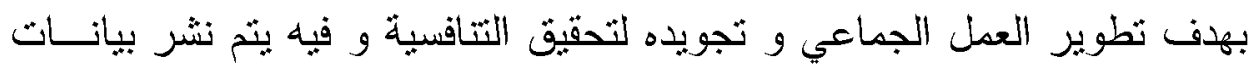

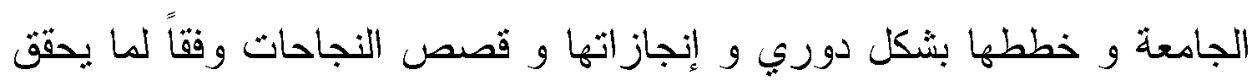
المزايا التتافسبة محلياً و عالمباً. ه. دعم و تعزيز موقع الجامعة الإلكثروني لما له من دور في تعزيـز العلاقــات

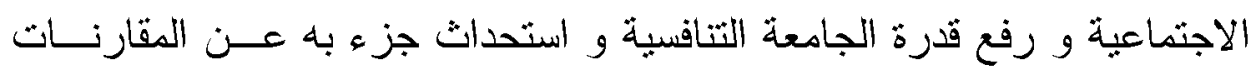

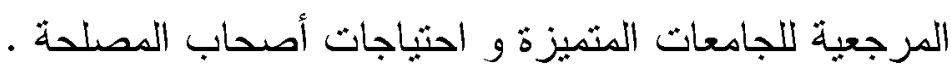
T. إقامة بر امج تدريبية و ورش عمل لكافة أعضاء هيئة التذريس بالجامعسـة عـن

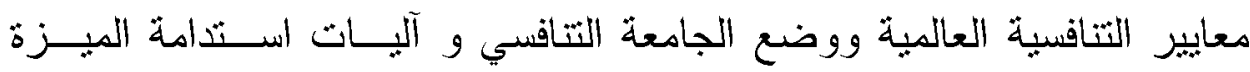

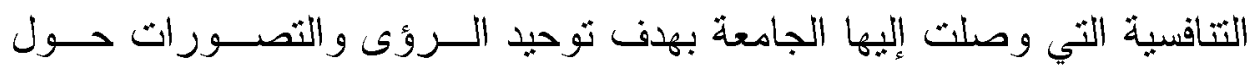
امتلاك الجامعة لمقومات التتافية و كيفية الحفاظ عليها . V. إدراج خطط الجامعة الحالية و المسنقبلية عن تحسين الوضع التنافسي بناء على متغيرات البيئة المحيطة في نشرات ثرسل لرؤساء الأقسام للعرض في مجــالس 
متطلبات تطوير الميزة التنافسية لجامعة أسوان في ضوء الاتجاهات العالمية المعاصرة

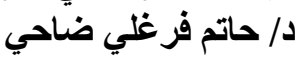

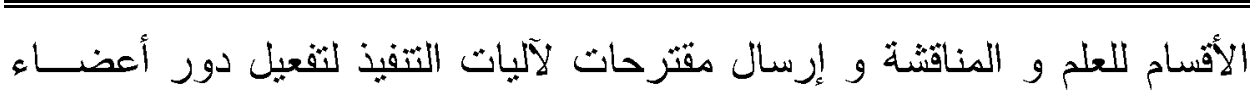

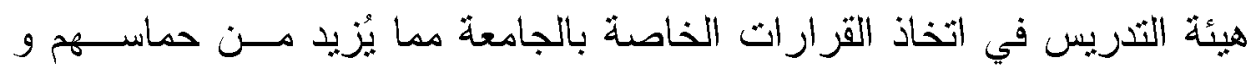

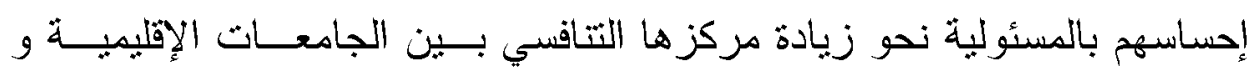

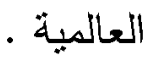
A. الاستغلال الأمثل لموارد الجامعة المادية من معامل و مـدرجات و ملاعـب و

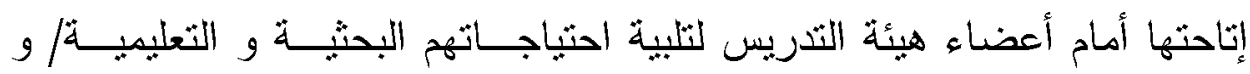
تمكينهم من أداء أعمالهم في الوقت المناسب و بأعلى كفاءة . 9. إنشاء قاعدة بيانات لمنطلبات التنافسية تشمل الظروف البيئية المحيطة بالجامعة و

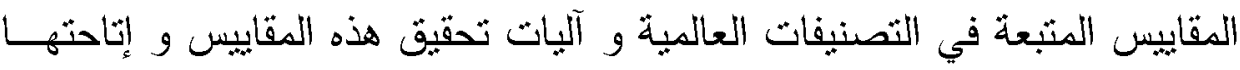
باستمر ار لأعضاء هيئة التدريس .

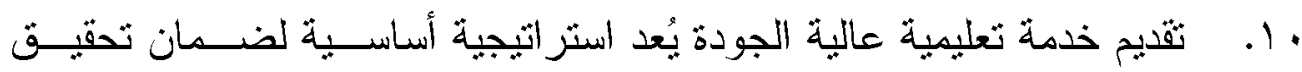
النجاح و البقاء و بناء مركز ها التتافسي و زيادة حصنها السوقية و ثقليل التكاليف في البيئة التتافسية . 


$$
\text { ملحق (1) جامعة أسوان -كلية التربية -قسم أصول التربية }
$$

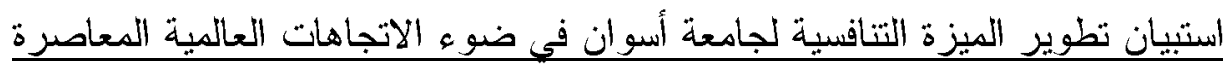

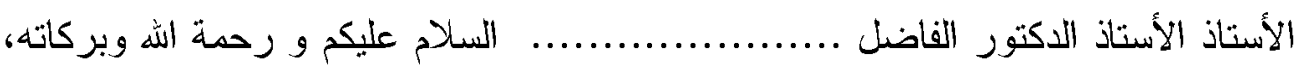

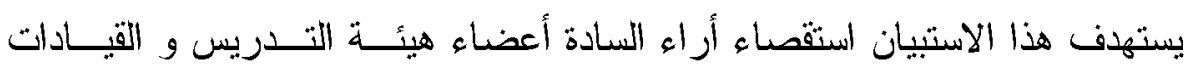

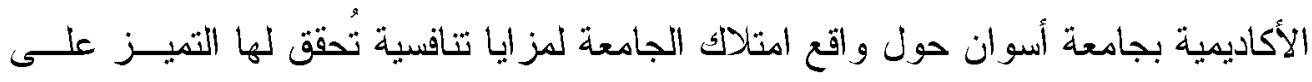

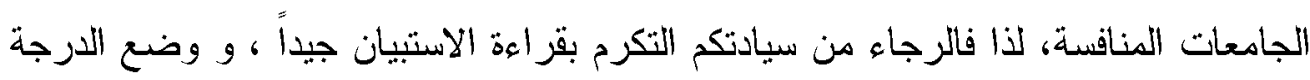

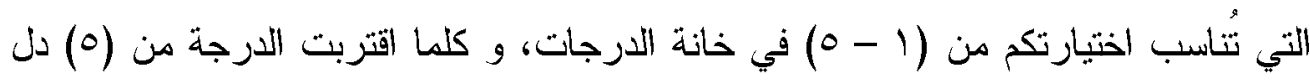

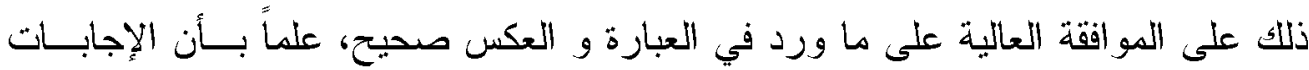

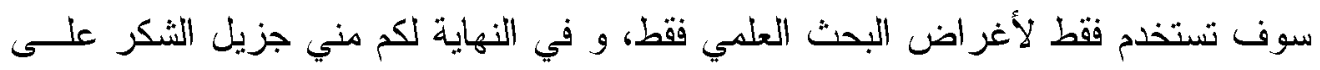

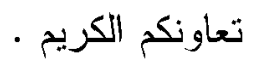

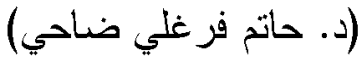

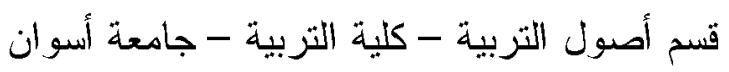

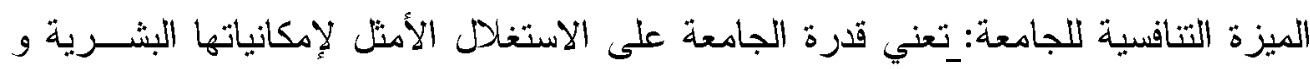
المادية و المالية والتنظيمية، لتتمكن من تزويد عملائها بمنتجات تعليمية و بحثية و مجتمعية أكثر كفاءة من المنافسين.

\begin{tabular}{|c|c|c|}
\hline الدرجة & أولاً: أبعاد الميزة التنافسية للجامعة & ? \\
\hline \multicolumn{3}{|c|}{ البعد الأول: الجودة المتفوقة } \\
\hline & | تُقدم الجامعة منتجات و خدمات عالية الجودة تُلبي رغبات العملاء و & 1 \\
\hline & المحلية و العالمية . ل & r \\
\hline & التبنى الجامعة استخدام الطرق و الأساليب الكفيلة بتطوير كفاءة المنتجات و & $\mu$ \\
\hline & مطُ اعي الجامعة عند تقديم منتجاتها و خدماتها التعليمية و البحثية و المجتمعية & $z$ \\
\hline
\end{tabular}


متطلبات تطوير الميزة التنافسية لجامعة أسوان في ضوء الاتجاهات العالمية المعاصرة

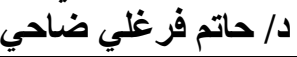

\begin{tabular}{|c|c|c|}
\hline | الدرجة & أولاً: أبعاد الميزة التنافسية للجامعة & r \\
\hline & تُوفر الجامعة الموارد المادية و القدرات البشرية التي تُور أدائها و تدعم & 0 \\
\hline & بُوجد بالموقع الإلكتروني للجامعة خدمات جامعية ذات جودة عالية قياساً & 7 \\
\hline & التُشجيع الجامعة أعضاء هيئة التدريس على تقديم مُبادرات للارنقاء بالخدمات & $V$ \\
\hline \multicolumn{3}{|c|}{ البعد الثاني: الإبداع المتفوق } \\
\hline & 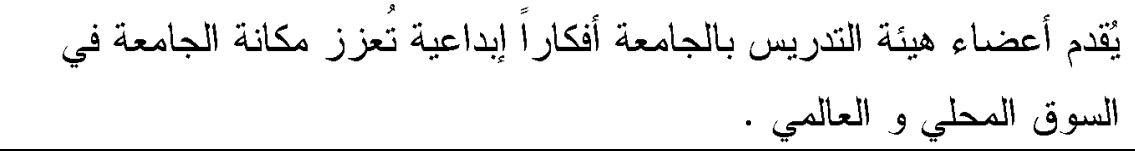 & 1 \\
\hline & تقتهج الجامعة سياسة التجديد في منتجاتها و أساليب العمل بها كجزء من & r \\
\hline & تثتوم الجامعة بتطوير منتجاتها و خدماتها اعتماداً على دراسات السوق الجديدة & r \\
\hline & تمتلك الجامعة نظاماً يُشجع على استقطاب الكوادر الأكاديمية الفريدة و & $z$ \\
\hline & خدمات الجامعة الجامعة تكنولوجيا متطورة تُساعد على تطوير و تتويع منتجات و & 0 \\
\hline & 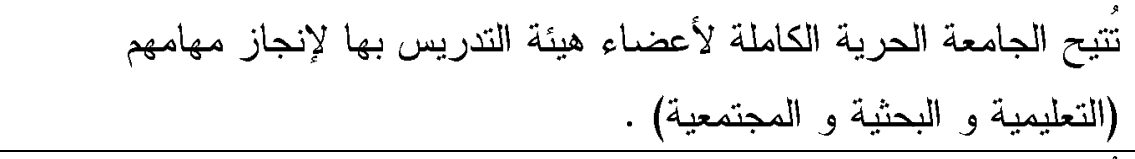 & 7 \\
\hline & 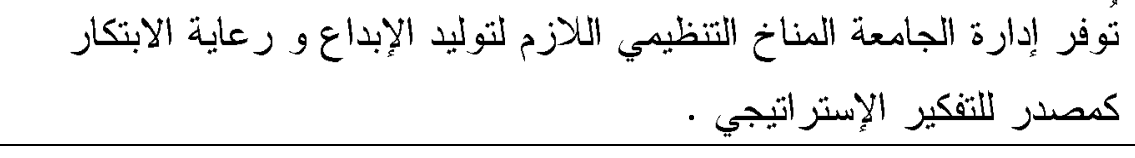 & $r$ \\
\hline \multicolumn{3}{|c|}{ البعد الثالث: الاستجابة المتفوقة لحاجات العملاء و المستفيدين } \\
\hline & كماً و نوعاً الجامعة بقدرة عالية على الاستجابة لكافة حاجات العملاء و المستفيدين & 1 \\
\hline
\end{tabular}


متطلبات تطوير الميزة التتافسية لجامعة أسوان في ضوء الاتجاهات العالمية المعاصرة

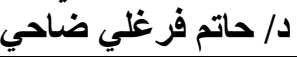

\begin{tabular}{|c|c|c|}
\hline الدرجة & أولاً: أبعاد الميزة التنافسية للجامعة & r \\
\hline & في التزتم الجامعة بتسهيل وصول المنتجات الجامعية إلى جميع أصحاب المصلحة & $r$ \\
\hline & تهنم الجامعة ببحوث التسويق بُغية التعرف على احتياجات العملاءو و & $r$ \\
\hline & تحترم الجامعة مو اعيد تقديم المنتج أو الخدمة بجودة و كفاعة عالية و بتقنية & $z$ \\
\hline & وقتلك الجامعة التسهيلات التقنية اللازمة لتوصيل خدماتها للمستفيدين بأسرع & 0 \\
\hline & الخدمات التي تُقدمها لهمه. مصادر معلومات تتعلق برضا العملاء عن المنتجات و & 7 \\
\hline \multicolumn{3}{|c|}{ البعد الر ابع: المرونة } \\
\hline & تلتصف الخطط و السياسات المُتبعة في الجامعة بالمرونة لتحقيق الأهداف & 1 \\
\hline & 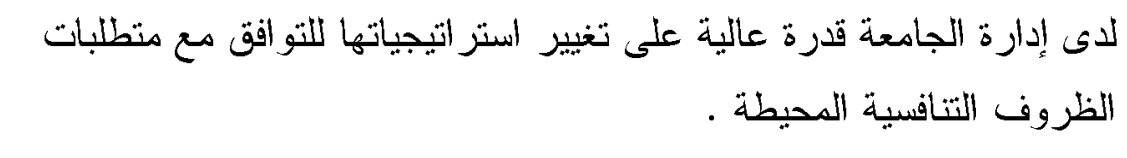 & $r$ \\
\hline & تسين الاعتبار . تجعة للعملاء و المستفبدين من خدماتها بتقديم مقترحاتهم و تأخذها & $r$ \\
\hline & 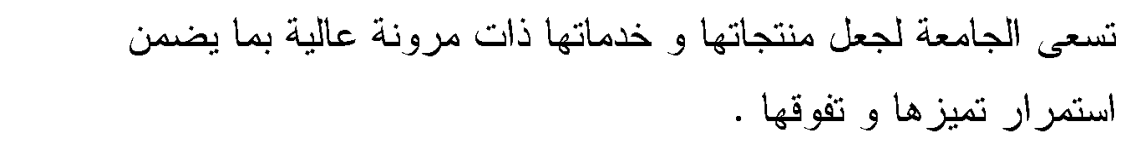 & $\varepsilon$ \\
\hline & تحرص الجامعة على الاتصال المباشر مع العملاء لتقديم خدمة جامعية & 0 \\
\hline & تُقيم الجامعة باستمر ار جودة خدماتها من أجل التحسين المستمر بمرونة و & 7 \\
\hline
\end{tabular}


متطلبات تطوير الميزة التتافسية لجامعة أسوان في ضوء الاتجاهات العالمية المعاصرة

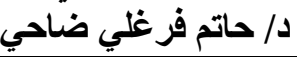

\begin{tabular}{|c|c|c|}
\hline 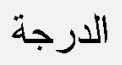 & أولاً: أبعاد الميزة التنافسية للجامعة & r \\
\hline \multicolumn{3}{|c|}{ البعد الخامس: (التكلفة ) ترشبد النقات } \\
\hline & تسعى الجامعة إلى خفض تكاليف الإنتاج من خلال البحث و التطوير و & 1 \\
\hline & تسالجامعة بتكلفة أقلى . تجامعة تقنيات حديثة مرنة في إنجاز العمليات التشغيلية و الإدارية & $r$ \\
\hline & تسعى الجامعة للاحتفاظ بالكفاعات من أعضاء هيئة الترريس و العاملين & r \\
\hline & تحاول الجامعة تخفيض الخدمات التكميلية و تشتخدم مواردها المالية بصورة & $\varepsilon$ \\
\hline & بُعد تخفيض التكاليف و ترشيد النفقات و حسن استخدام الموارد من الأهداف & 0 \\
\hline & تنتهج الجامعة منهجبة تقديم المنتجات و الخدمات عالية الجودة بأقل تكلفة & 7 \\
\hline & البعد السادس: التميز و التفوق على المنافسين & \\
\hline & تُعد مخرجات الجامعة عالية الجودة و متميزة بالنسبة للجامعات الأخرى & 1 \\
\hline & تعمل الجامعة على استقصاء المعلومات عن رغبات الطلاب و احتياجات & $r$ \\
\hline & تعتمد الجامعة على نظم معلومات إدارية تُسق بين الإدار ات الجامعبة في & r \\
\hline & تمنلك الجامعة نظام رقابة يتضمن فحص و تقييم كفاءة العمليات الإدارية و & $\varepsilon$ \\
\hline & تلقدم الجامعة بر امج تعليمية في تخصصات علمية نادرة تفي باحنياجات سوق & 0 \\
\hline
\end{tabular}


متطلبات تطوير الميزة التنافسية لجامعة أسوان في ضوء الاتجاهات العالمية المعاصرة

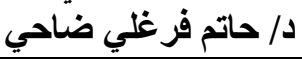

\begin{tabular}{|c|c|c|}
\hline 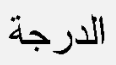 & أولاً: أبعاد الميزة التنافسية للجامعة & $\vec{r}$ \\
\hline & تُوكز الجامعة على تقديم نوع معين من المنتجات الجامعية التي لا تقدمها & 7 \\
\hline & تقابلة للتمليد و الجامعة بالموارد البشرية باعتبار ها قدر ات استر اتيجية لدى الجامعة غير & $V$ \\
\hline
\end{tabular}


قائمة المراجع

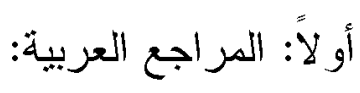

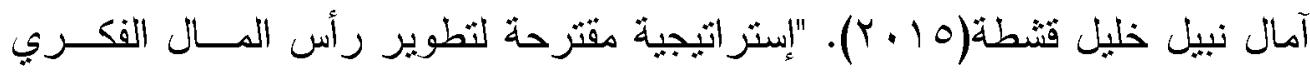
لتحقيق المبزة التناقسية في الجامعات الفلسطينية". رسالة ماجسنير غير منشورة. كلية

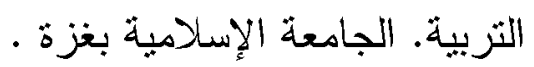

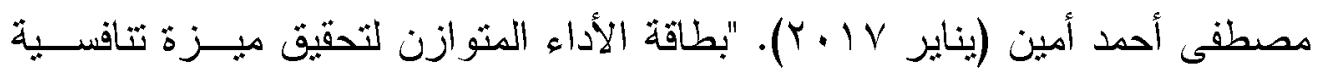
للجامعات المصرية". مستقبل الثربية العربية. المركز العربــي للتعلــــم و التنميــة.

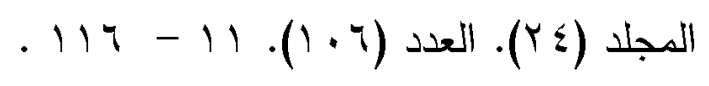
سعود بن عيسى النايف (أبريل با + ب). "دور نكنولوجيا المعلومات في تحقيق مزايا تتافسية لمؤسسات التعليم العالي: در اسة استطلاعبة في جامعة حائل". مجلة در اسات

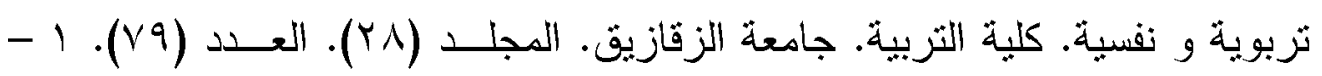
.07

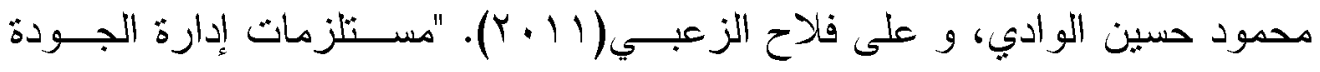

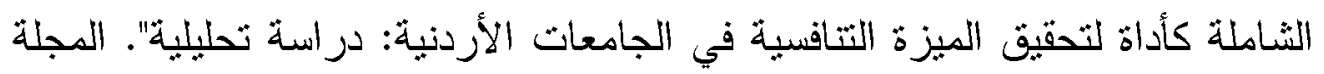

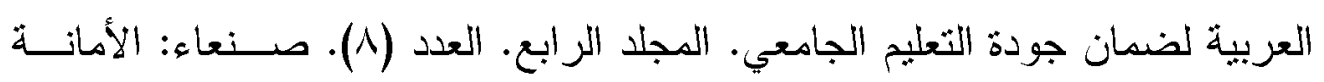

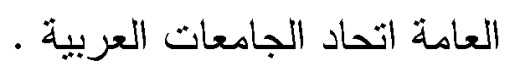
خالد أحمد عبد الحمبد قتشق(ع ا ـ ب). "إدارة رأس المال الفكري و علاقته في تعزيز

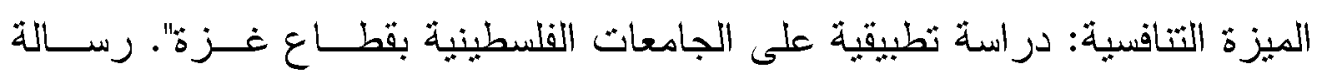
ماجستبر غير منتورة. قسم إدارة الأعمال. كلية الاقتصاد و العلوم الإدارية. جامعة الماته

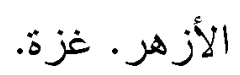

منال أحمد على الفقبه(1 ( • ب). "دور الرشاقة الإستراتيجية في تحقيق الميزة التنافسية

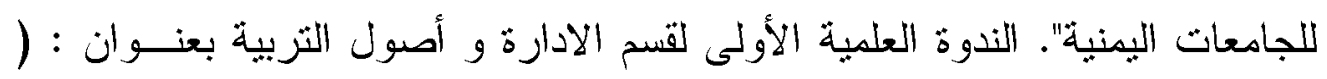
آفاق مستقبل المؤسسات التحليمبة في اليمن). كلبة التربية ـ جامعة إب ـ البمن ـ في

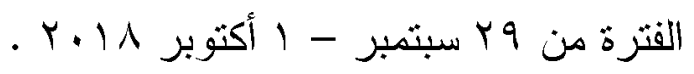


محمد عبدله محمد عبدلله(9 ( ـ r). "تصور مقترح لنحقيق الميزة التتافسية لمؤسسات التعليم العالي بثطييق مدخل سلسلة القيمة في ضوء بعض النماذج العالمية". مجلــة

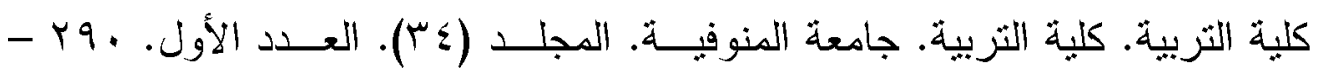
$r \leqslant 0$

حمدي جمعة عبد العزيز (يناير با +ب). "دور تسويق الخدمات الجامعية في تحسين القدرة التتافسية من وجهة نظر الدارسين بجامعة حلوان". المجلة العلمية للاقتصاد و

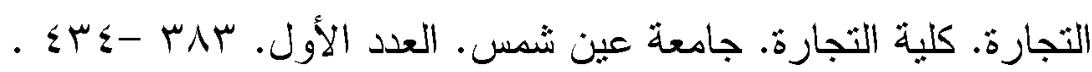

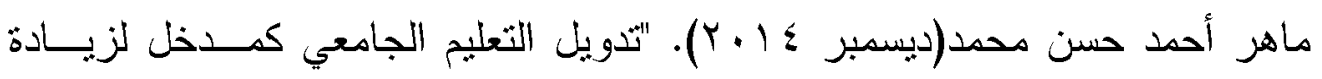

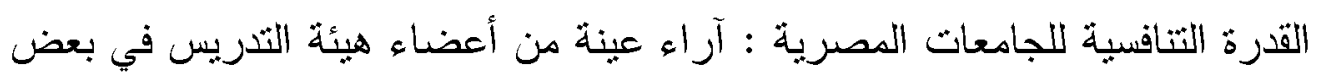

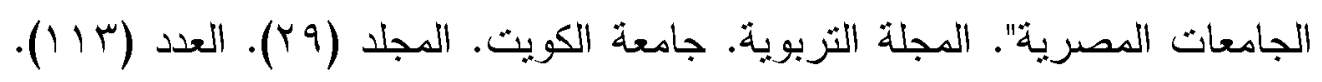
. YIA-IEI

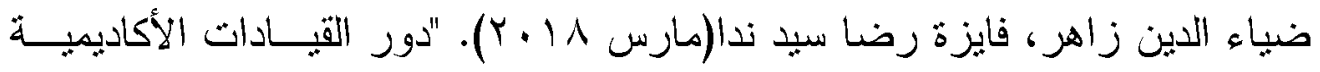

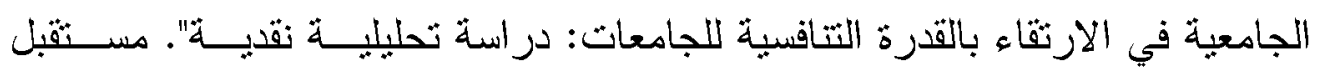

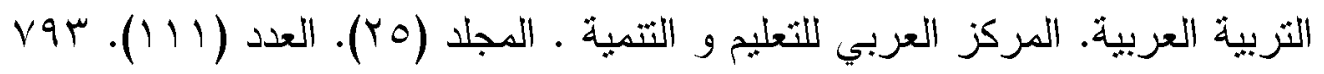
. Ar. -

هنية جاد عبد الغالي(ب ( • ب). "المنطلبات التربوية لتفعيل جودة العمليات الإداريــة بالجامعات المصرية في ضوء الاتجاهات الحديثة للإصلاح الثربوي". رسالة دكتور اه غير منشورة. كلية التربية. جامعة أسوان .

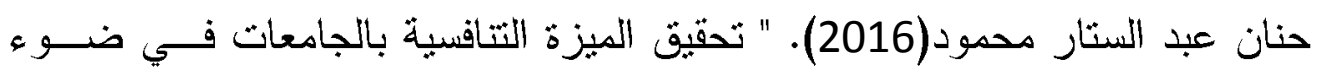

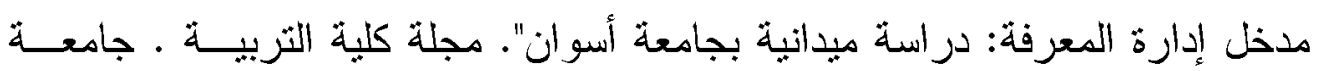
دمنهور • المجلد الثامن • العدد الرابع.

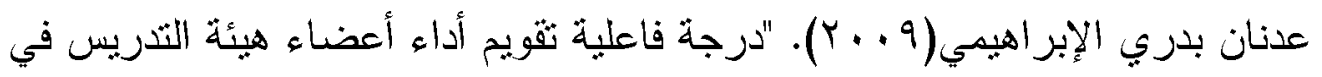

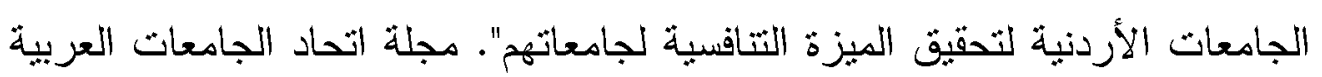

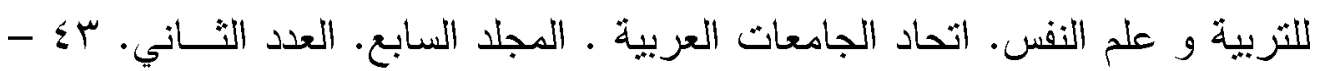
. VT 


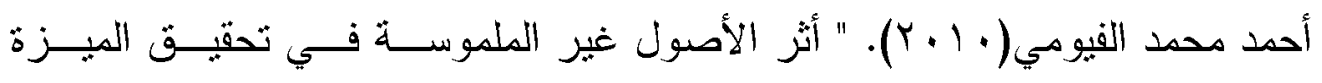
التتافسبة في ظل ثبني معايير إدارة الجودة الثشاملة : دراسة مقارنة على عينة مسن

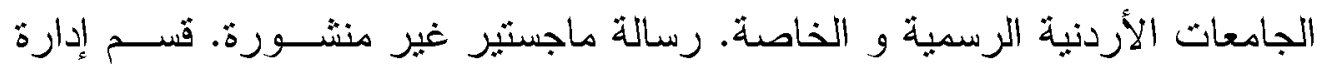

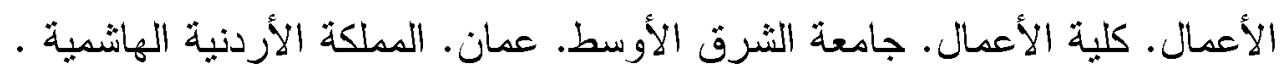

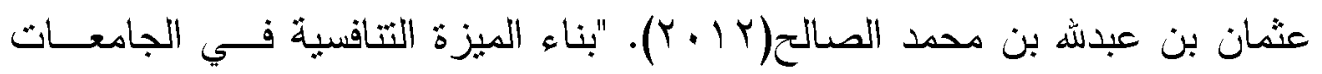
الحكومية السعودية". رسالة دكتور اه غير منشورة. كلية الثربية. جامعة أم القــرى. المملكة العربية السعودية. على محمد عليان علي(ب ( • ب). "منطلبات استدامة الميزة التنافسبة في التعليم العالي: وجهة النظر القائمة على أساس الموارد: دراسة حالة الجامعسـة الإســلامية بغــزة". رسالة ماجستير غير منشورة. قسم إدارة الأعمال. كلية التجارة. الجامعة الإســلامية الفهية بغزة .

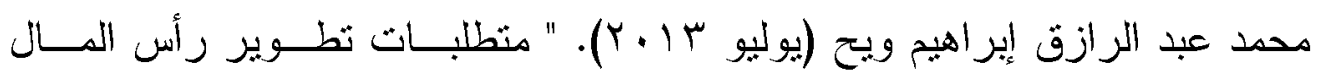

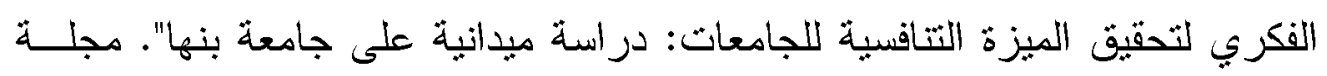

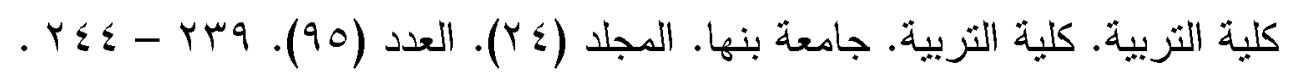

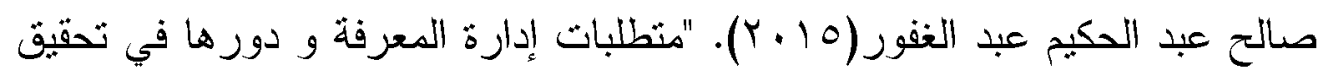
الميزة التتاقسية في جامعات قطاع غزة". رسالة ماجستير غير منشـــورة. برنــامج

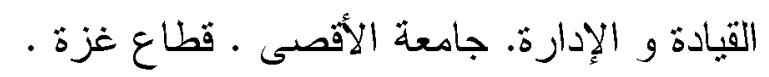

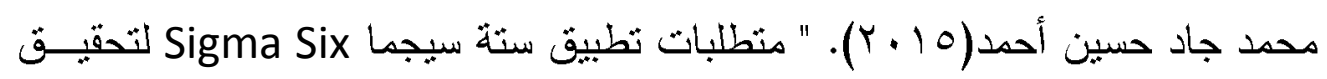
الميزة الثنافسية بالجامعات: دراسة تطبيقية على بعض كليات جامعة جنوب الوادي".

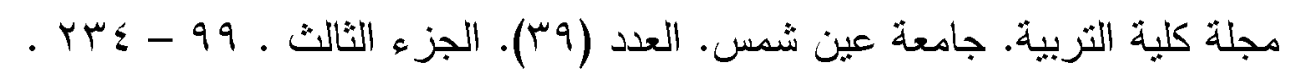

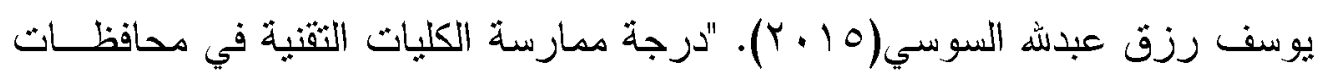
غزة لإدارة الثميز وعلاقتها بالميزة التتافسية". رسالة ماجسثير غير منشورة. كليــة التزبية. الجامعة الإسلامية بغزة.

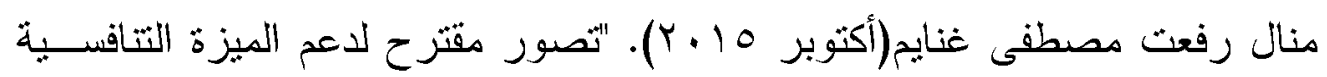
بالتعليم الجامعي المصري على ضوء متطلبات اقتصاد المعرفة". مجلـــة دراســات 
ثربوية و اجثماعبة. كلية الثربية. جامعة حلوان. المجلد (ب). العسدد (ع). سابr . $\Sigma \cdot Y$

اسماعيل صبحي كحيل(ب ( ץ). " إدارة الجودة الثشاملة و علاقتها بالميزة التتافسية: در اسة ثطيقية على العاملين في جامعة فلسطين". رسالة ماجستير غيــر منتـــورة. البرنامج المشترك بين أكاديمية الإدارة و السياسة للار اسات العلبا و جامعة الأقصىى.

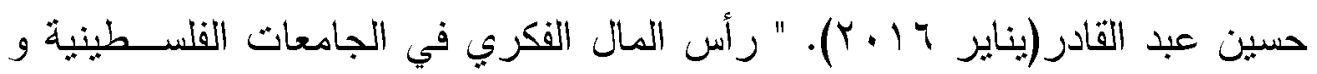

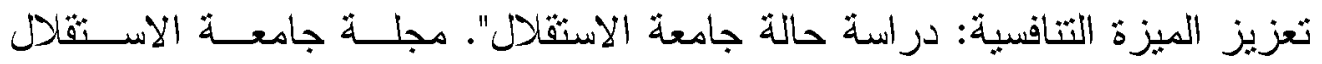

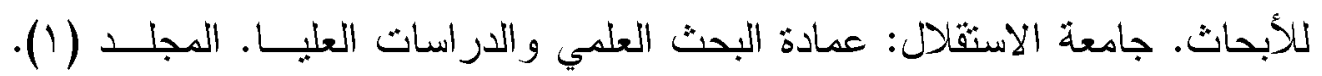

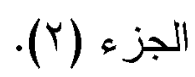

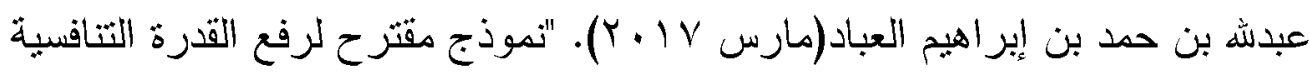
لجامعة الملك سعود في ضوء معايير التصنيفات العالمية للجامعات". المجلة الثربوية الدولية المتخصصة. الجمعية الأردنية لعلم النفس. المجلد (ب). العـدد (ب). الجـزءء

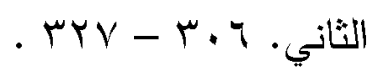

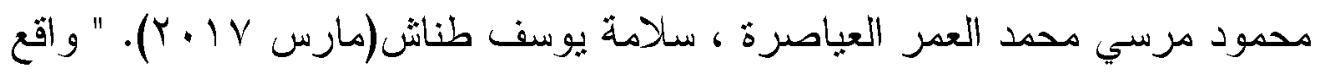

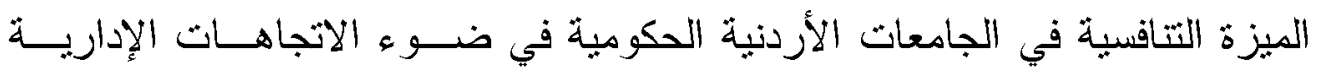
المعاصرة". المجلة التربوية الأردنية. الجمعية الأردنية للعلوم التربوية. المجلد (Y).

$$
\text { العدد (1) TIY - IV9 }
$$

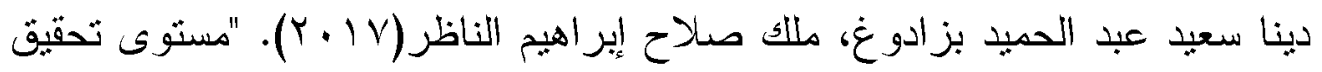

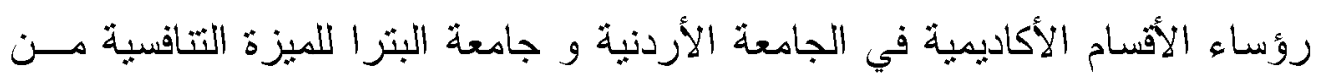

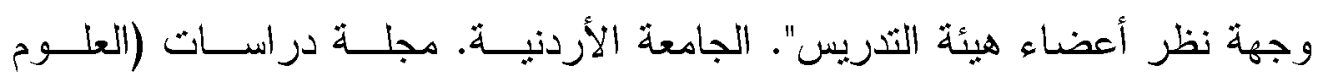

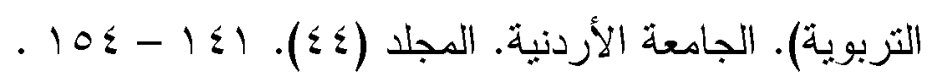

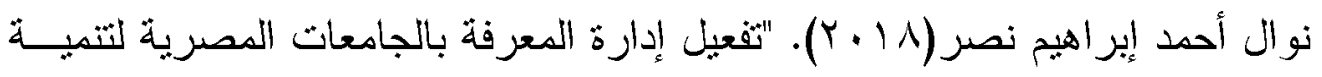

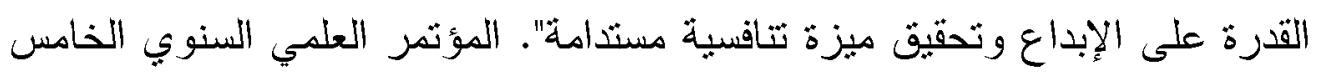

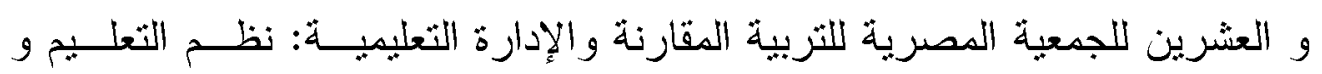


مجنمع المعرفة. الجمعية المصرية للتربية المقارنة و الإدارة التعليمية. في الفنرة من

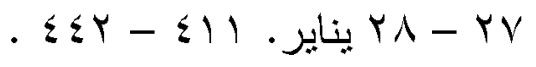
جابر عبد الحميد جابر، أحمد خيري كاظم (9NVV) (19v). مناهج البحث في التربية و علم

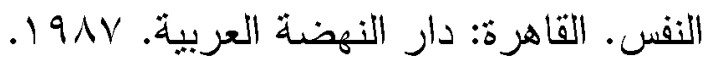
أحمد محمود خليل الأسطل (· ( ب). " دور بيانات التكالبف في تفعيل القدرة التتاقسية في ضوء آلبات الحوكمة: دراسة تطبيقية على الثركات الصناعية المدرجة في سوق

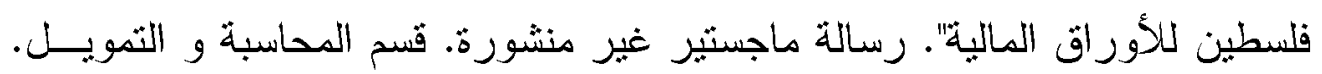
كلبة التجارة. الجامعة الإسلامية بغزة.

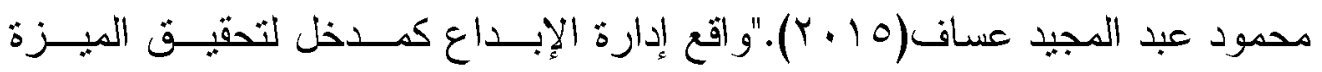
التتافية التتافسية في مؤسسات التعليم العالي بمحافظة غزة و استر اتيجية مقترحسـة

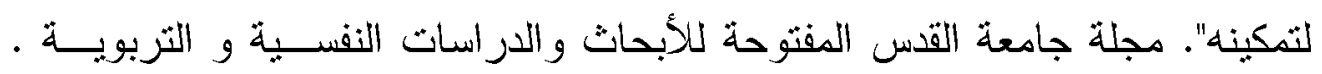

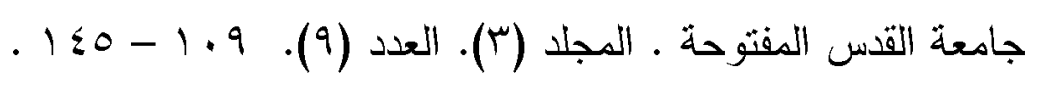

أسامة زين العابدين عثمان، منال موسى سعيد(أبريل 0 ـ ب). "تصور مقترح لتفعيل الميزة النتافسية لكلية الثربية بالو ادي الجديد: دراسة مبدانبة". مجلة كلية التربية. كلبة مونية

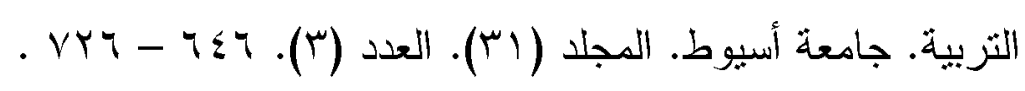

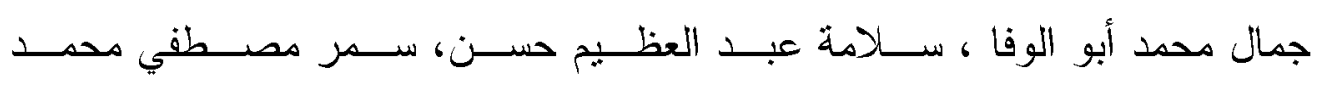

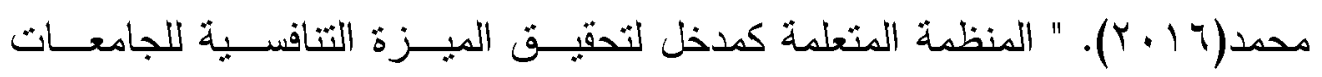

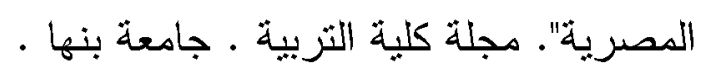
ندى حسين جودة(11 + r). "التخطيط الإسنر اتيجي للموارد البشرية كمدخل لتعزيــز القدرات النتافسية: دراسة ثطبيقية على شركات الأدوية بجمهورية مصر العربيــة".

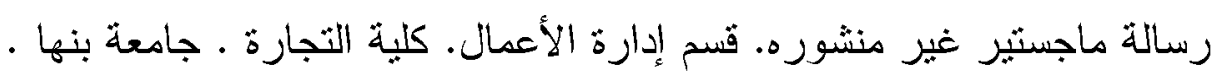

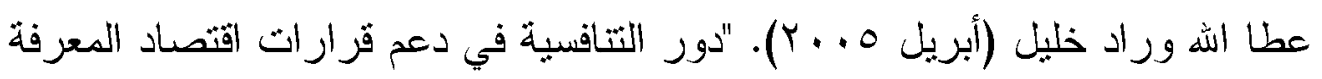

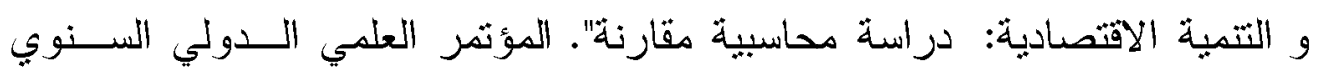
الخامس: اقتصاد المعرفة و التتمية الاقتصادية. كلية الاقتصاد و العلــوم الإداريــة. جامعة الزيثونة الأردنية. عمان V Y Y أبريل . 
سناء عبد الرحبم سعيد(أكتوبر سا • ب). " منطلبات تحقيق الميزة التتافسية المستدامة

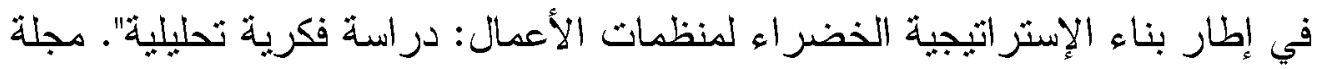

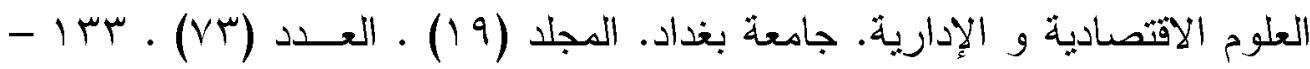
. 174

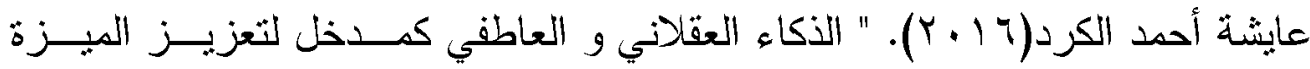
النتافسية في الكليات التثنية في قطاع غزة". رسالة ماجستير غير منشـــورة ـ كليــة التجارة. الجامعة الإسلامية بغزة. فلسطين. حنان البدري كمال سليمان (مارس 9 ( • Y). "استراتيجية مقترحة لتفعيل دور التعلم التنظيمي في تحقيق الميزة التنافسبة لجامعة أسوان". المجلة التربوية. جامعة سو هاج.

$$
\text { العدد (090 - ovor). }
$$

محد نصحى سبد إبر اهيم 9 . . ب). "المشرو عات النتافسية في الجامعات المصــرية بين الواقع و المأمول مع التطبيق علي كليات التربية" المؤتمر الدولي الثاني لنطوير

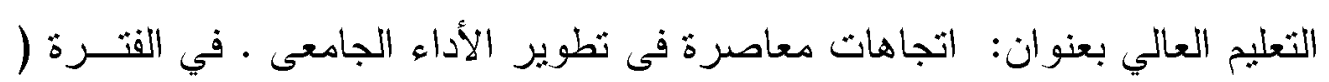

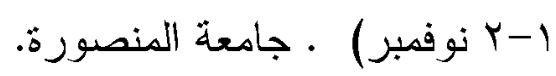

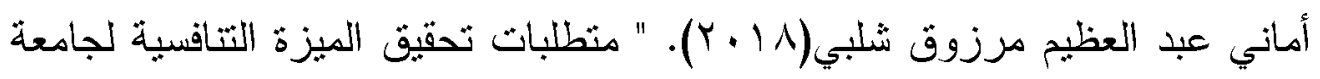

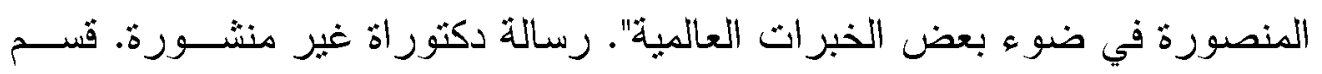
أصول الثربية. كلية التربية. جامعة المنصورة. بعضئ.

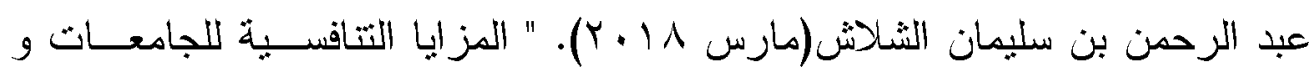
الكلبات الأهلية بالمملكة العربية السعودية و سبل تحسينها". مستقبل التربية العربية.

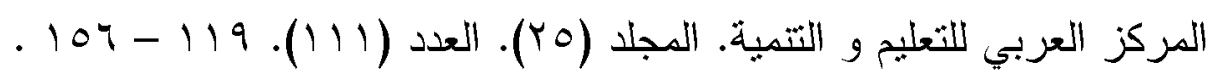
نجلاء عبد التواب عيسى (1) (ب). "دور رأس المال الاجنماعس في تحقيق استدامة

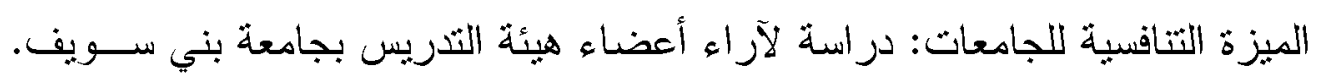

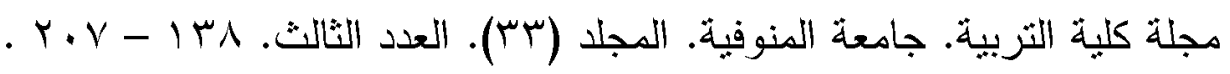




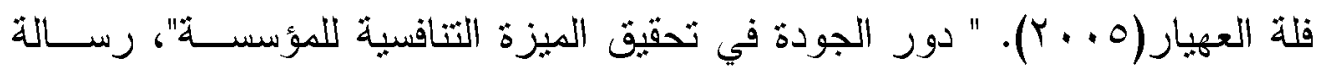
ماجسنير غير منشورة. قسم علوم التسيير. كلية العلوم الاقتصادية و علوم التشـبير

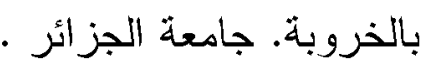

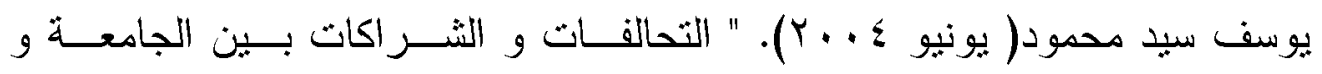
المؤسسات الإنتاجية: مدهل لتطوير التعليم الجامعي". مجلة در اســات فــي التعلــيم الجامعي. مركز تطوير التعليم الجامعي. كلية التربية. جامعة عين شمس. العدد (؟). $.00-$ - rs

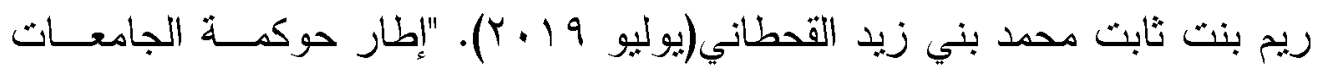

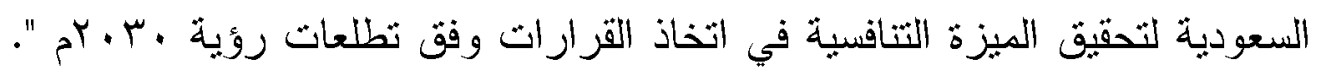

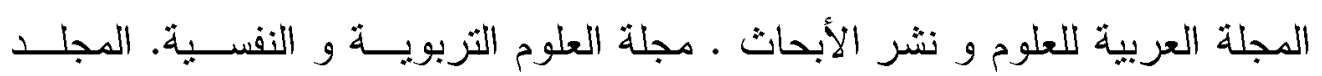

$$
\text { الثالث. العدد الخامس عشر. . } 01 \text { - v . }
$$

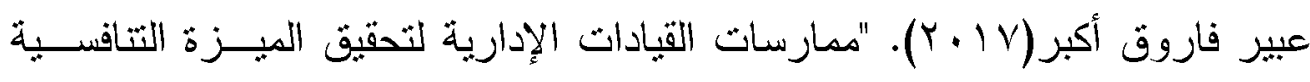

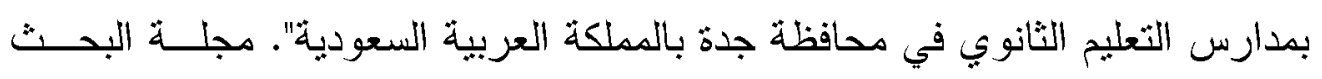

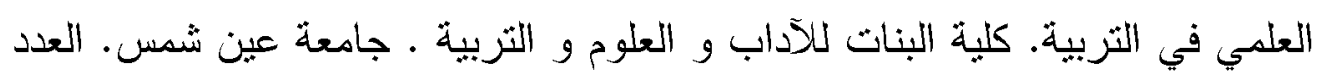

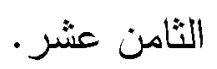

معموري صورية، هجيرة الثيخ (نوفمبر · ل • ب). "محددات و عوامل نجاح الميزة التنافسية في المؤسسة الاقتصادية". الملتقى الدولى الرابع: المنافسة و الاستر اتيجيات التتاقسية للمؤسسة الصناعية خارج قطاع المحروقات في الدول العربية. كلية العلوم الاقتصادية و علوم التسبير · جامعة حسيبة بن بو علي بالثلف. 1 - Y Y.

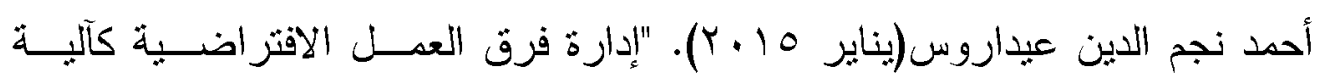
استر اتيجية لتحقيق الميزة التتافسية في الجامعات المصرية". مجلة كليــة التربيــة.

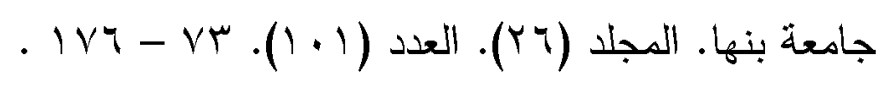
أمل صلاح الحارون(يونيه 9 1 • (ب). "درجة ممارسة الإدارة الإستر اتيجية لدى عمداء

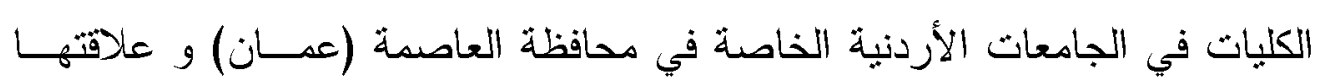


بالمبزة التتاقسية من وجهة نظر رؤساء الأقسام وأعضاء هيئة التـدريس". رسـالة

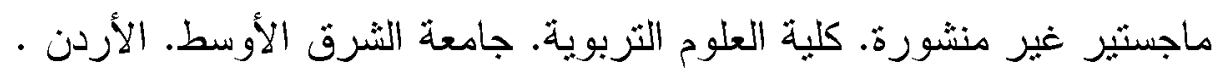

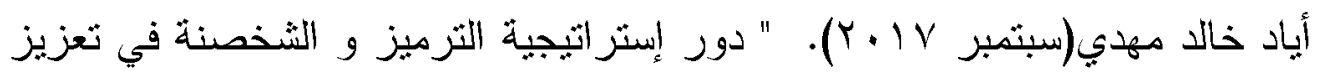
الميزة التتافسية: دراسة استطلاعية لآراء عينة من المديرين في المصارف العر اقية

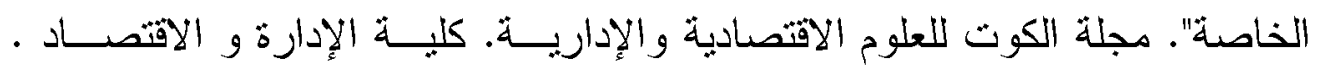

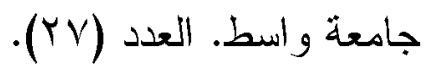
دبا شيما (ب ا • Y). "دور رأس المال الفكري في تحقيق الميزة التنافسية للمؤسســات الصغيرة و المنوسطة : دراسة حالة مؤسسة سيفانكو لصناعة البيوث الصحر اوية". رسالة ماجستير غير منشوره. كلية العلوم الاقتصادية و التجارية و علوم التشـيبر.

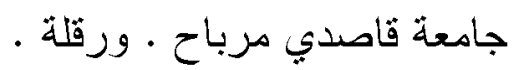

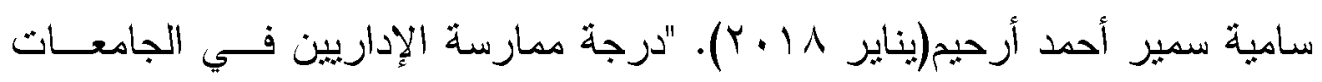

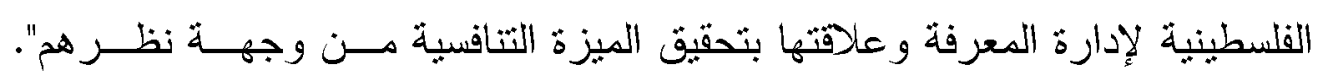

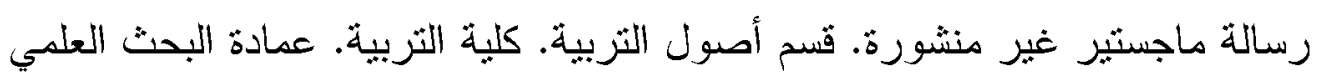
و الدراسات العليا ـ الجامعة الإسلامية بغزة.

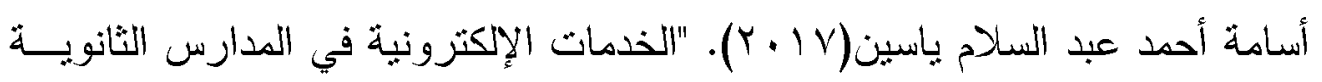

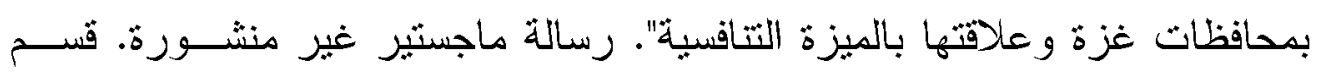
أصول النربية. كلية الثربية. الجامعة الإسلامية.

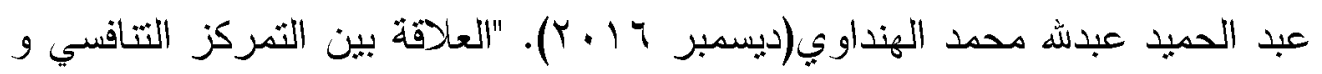
تطوير القدرة التتافسية المستـامة: دراسة تطبيقية على البــر امج المثمبـزة بكلبــات جامعة المنصورة". مجلة التجارة و التمويل. كلية التجارة . جامعة طنطا. العدد (ع). . $) \leqslant-Y \vee \leqslant$

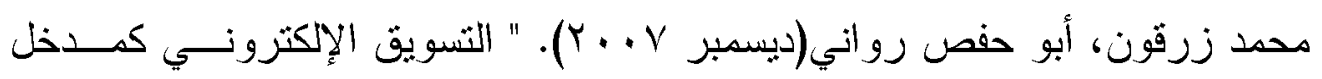
لتحقيق الميزة التتافسية في ظل اقتصاد المعرفة". الملتقى الدولى الثاني: المعرفة في ظل الاقتصاد الرقمي و مساهمتها في تكوين المزايا التتافسية للبلدان العربية. كليــة العلوم الاقتصادية و علوم النسيير · جامعة حسيبة بن بوعلى بالثلف. 
محمد إبراهيم عبد العزيز خاطر (10 ب ب). "تدويل التعليم: أحد مداخل ثحقيق المبزة التتاقسية للجامعات المصرية". مجلة دراسات ثربوية و نفسية. كلبة التربية ـ جامعة اهية

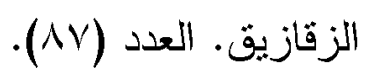

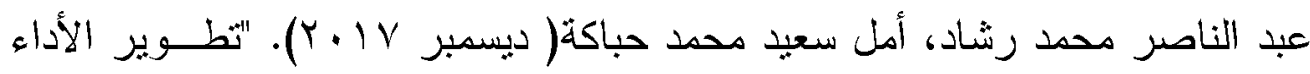
المؤسسي و تحقيق الميزة التنافسية بكليتي التزبية بجامعتي عين شمس و المجمعسـة: دراسة مقارنة". مجلة الإدارة الثربوية. الجمعية المصرية للتربية المقارنة و الإددارة

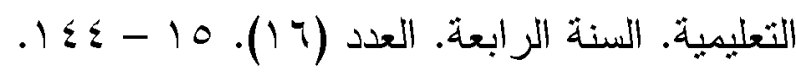

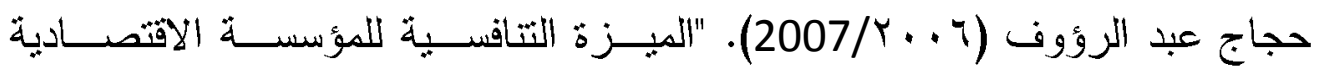
مصادرها و دور الإبداع الثكنولوجي في تنميثها: دراسة ميدانبة في شركة روائسـح

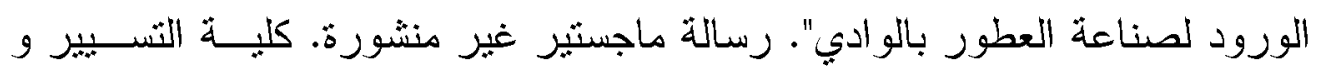

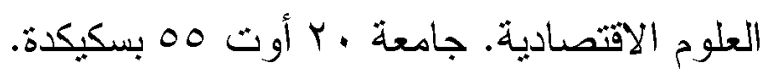

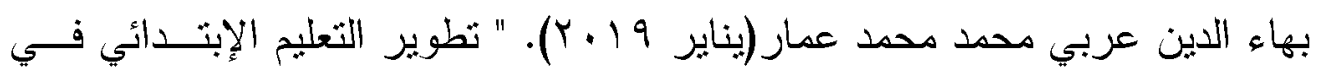
مصر لتحقيق الميزة التتافسية في ضوء مؤشرات التتافية العالمية". مجلة دراســات

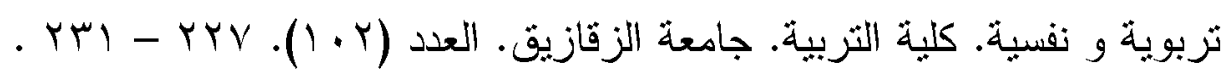

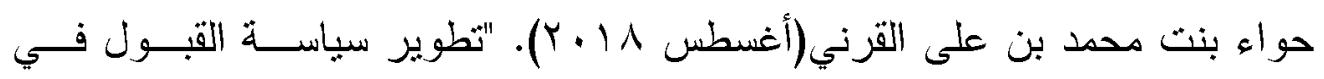

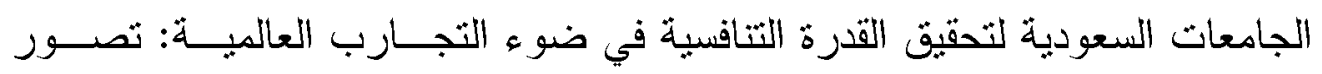

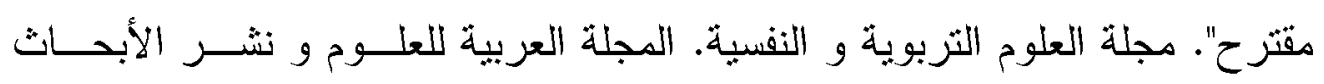
(AJSRP)

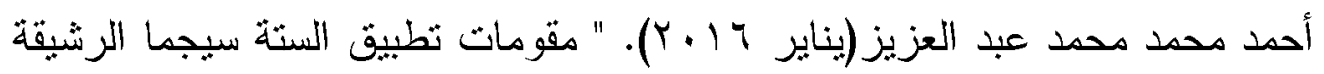

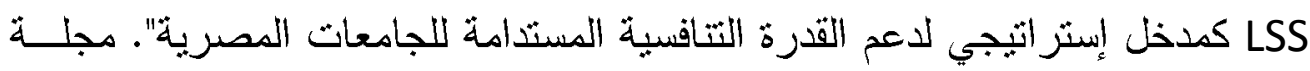

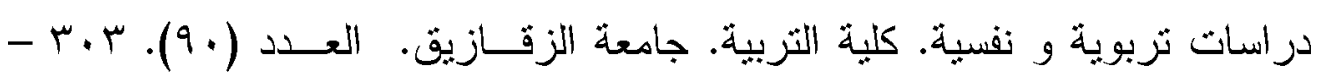
.$r v a$

محدد عشرى ، حسن عبد المهذى (؟ . . ץ). "مناهج و مؤشرات القـدرة التتافسـبة

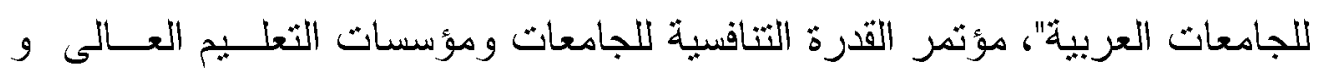


البحث العلمى المصرية و العربية فى إطار اتفاقيات تحرير التجـارة الدولبــة فــى الخدمات. جامعة حلوان في الفترة V - 9 مايو جامعة حلوان.

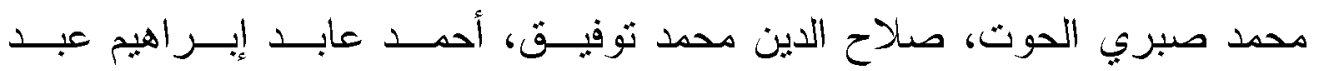

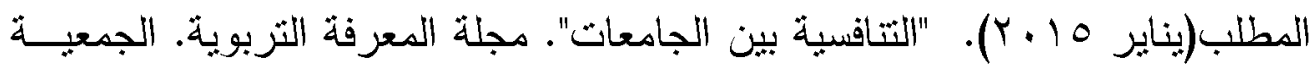

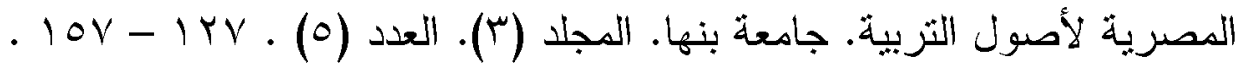

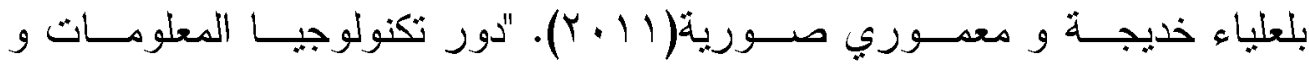
الاتصالات في اكنساب مزايا تتافسية في منظمات الأعمال". الملتقى الدولي الخامس

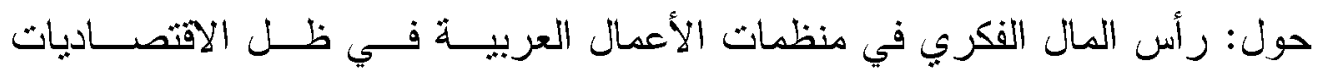

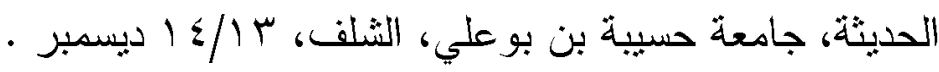

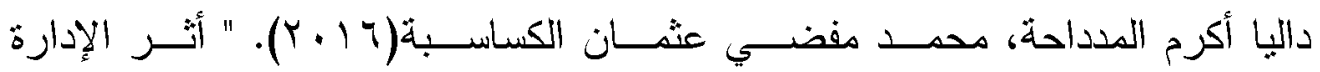

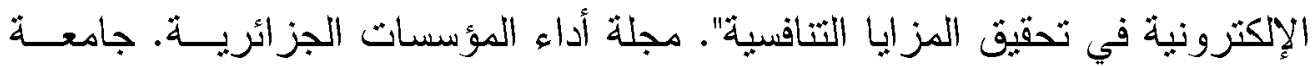

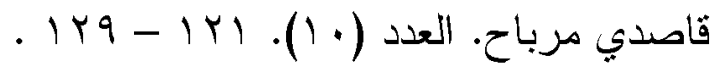

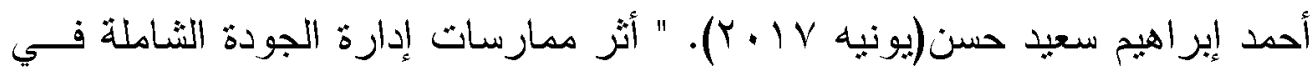

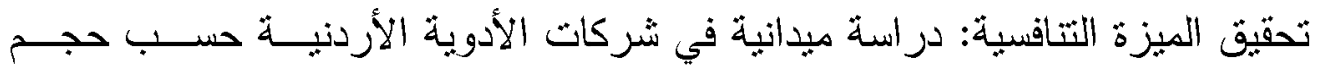
الشركات". رسالة ماجستير غبر منتورة. قسم إدارة الأعمال. كلية إدارة الأعمـال. جامعة الثرق الأوسط .

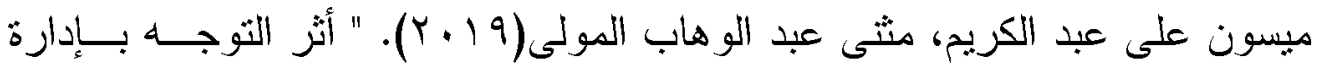
الجودة الثناملة و التميز التظظيمي في الميزة التنافسية المستدامة في الكليات الأهليــة العراقية". مجلة كلية بغداد للعلوم الاقتصادية الجامعة. العدد (N). . العدد الخـاص

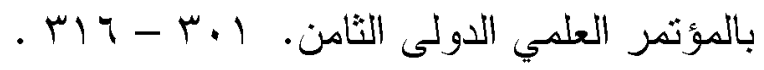

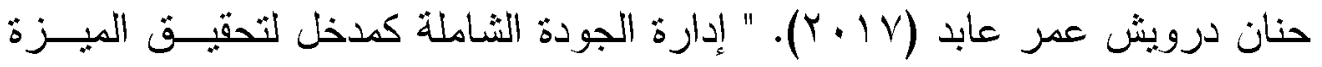
التتافسية في مؤسسات التعليم العالي السعودي". مجلة البحث العلمي في التربية. كلية البنات للآداب و العلوم و التربية . جامعة عين شمس. العدد (1 (). الجـزء ( (1). rYY- r.r 


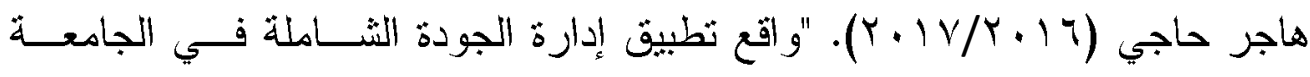

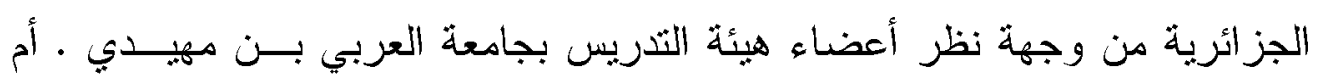

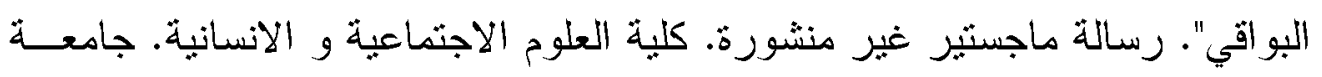
العزبي بن مهيدي أم البواقي. الجزائر .

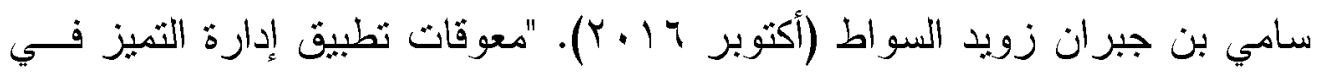

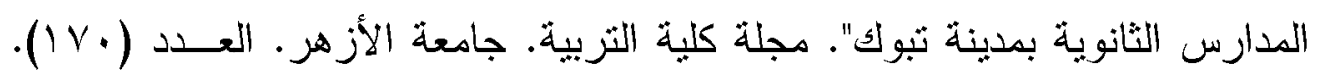
الجزء الثاني.

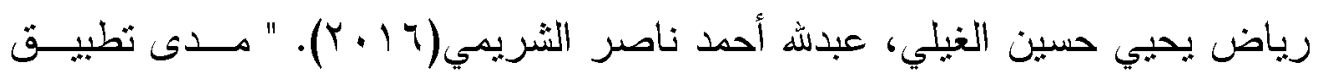

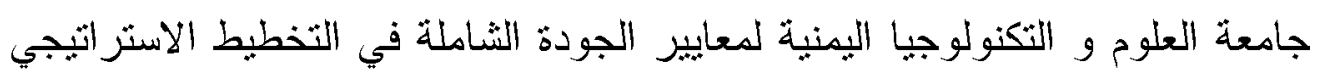
وفقاً للنموذج الأوروبي EFQM ". المجلة العربية لضمان جودة التعلــيم الجـامعي.

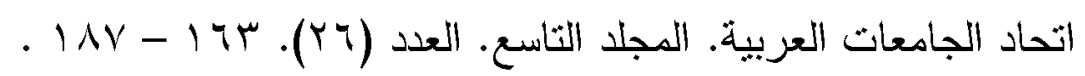

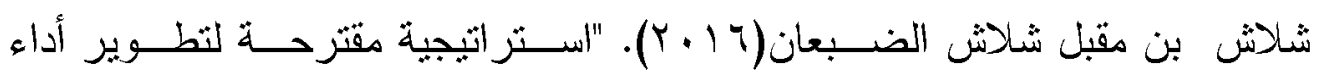
الجامعاث السعودية الناشئة في ضوء المعايير العالمية للتميز المؤسســيـ". رســالة

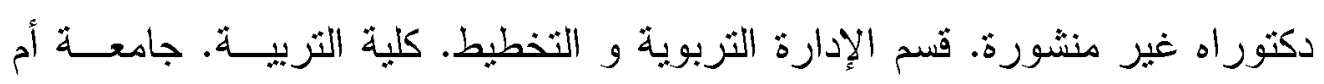
القرى. المملكة العزبية السعودية.

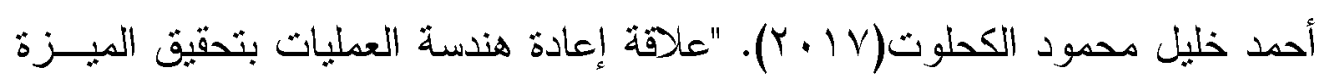
التناقسية في الجامعات الفلسطينية في غزة". رسالة ماجستير غير منشورة. برنـامج ماجستير إدارة الأعمال. كلبة الاقتصاد والعلوم الإدارية. جادعة الأزهر بغزة.

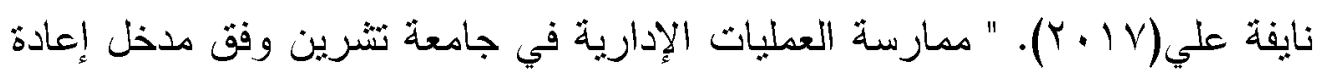
هندسة العمليات الإدارية من وجهة نظر أعضاء هيئة التعليمية و الإدارية بالجامعة".

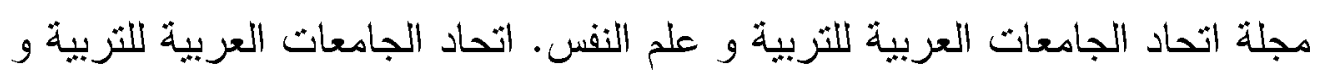
علم النفس. المجلد الخامس عشر . العدد الثاني. إسماعيل عبدله محمد قاسم(أغسطس 9. . . ب). "تحسين جودة الخدمة في الجامعـات

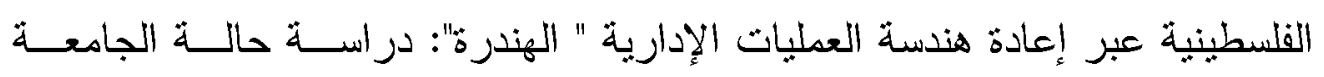


الإسلامية بغزة". رسالة ماجسنير غبر منشورة. قسم إدارة الأعمال. كلبة التجـارة .

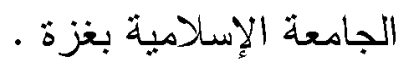

خدوج عزي عبده حداد(10 • ب). "دور القياس المرجعي الثشاهل في تحسين القـدرة التتاقسية : دراسة ثطيقية في المنشأت الصناعية". رسالة دكتور اة غير منشورة. قسم المحاسبة. كلية الاقتصاد. جامعة دمثن. درن.

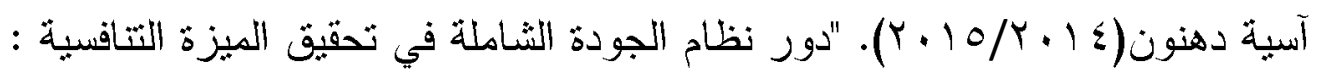
دراسة حالة اتصالات الجزائر بالو ادي". رسالة ماجستير غير منشورة. كلية العلــوم

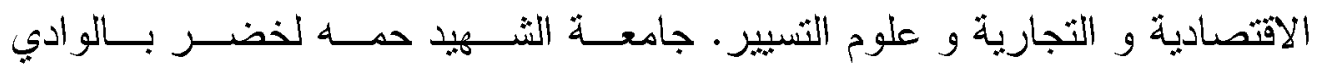
(بتصرف) (بن)

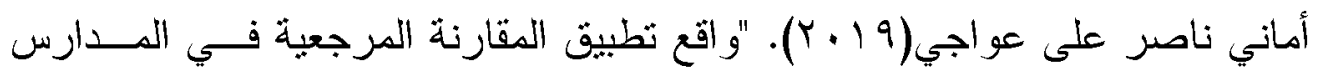

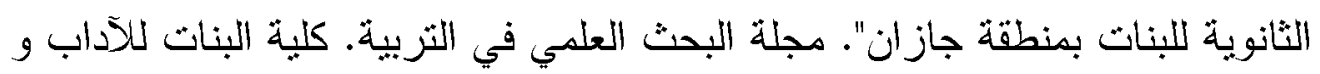

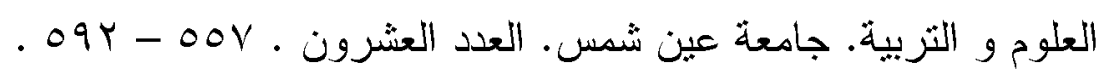

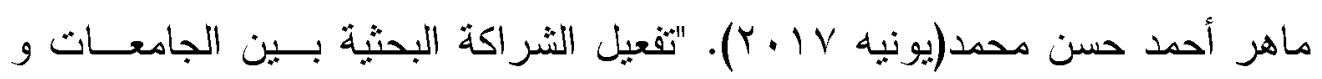

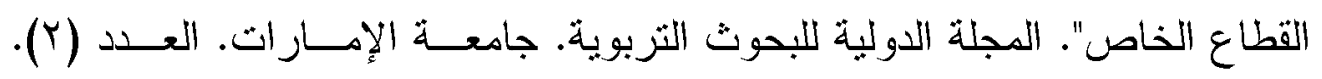

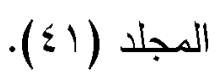

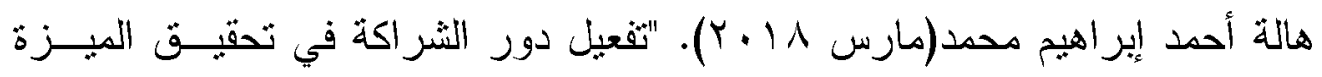

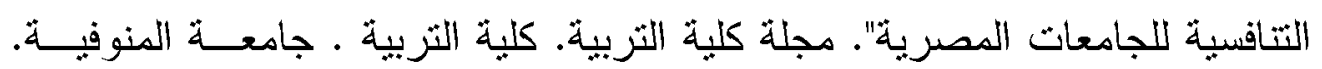

$$
\text { المجلد (سT). العدد(乏). . }
$$

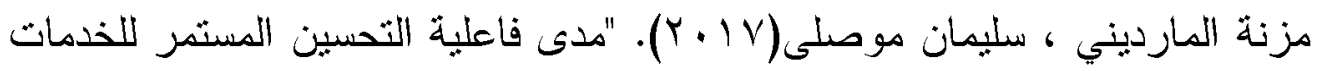

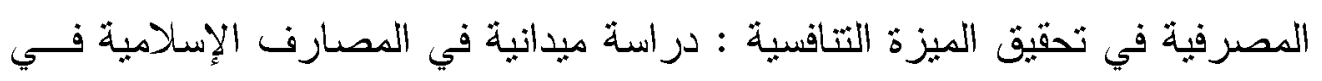
سوربية". مجلة جامعة تشرين للبحوث و الدراسات العلمية. سلسلة العلوم الاقتصادية

$$
\text { و القانونية. المجلد (qَ). العدد (1). }
$$

أماني السبد غبور (أبريل 1 1 • ب). " تصور مقترح لإدارة الكراسي البحثية بالجامعات

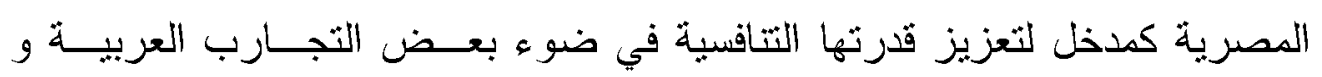


العالمية". مستقبل التربية العربية. المركز العربي للتعليح و التنمية. المجلـــ (ب). العدد (11) (11) - 11)

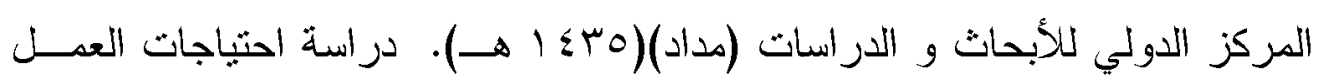

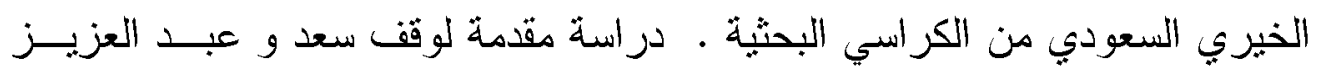

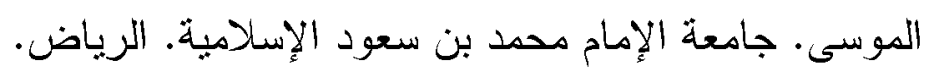

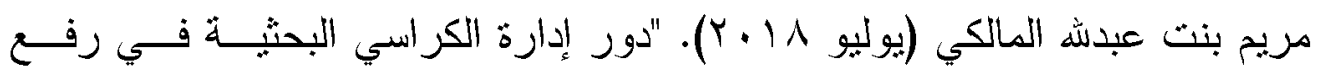

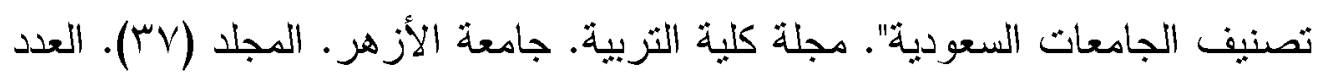

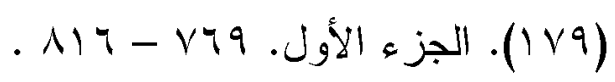

إيمان علي سليمان، غدير زين الدين فلبمان، وفاء عبــــ العزيــز شريف(ســبتمبر

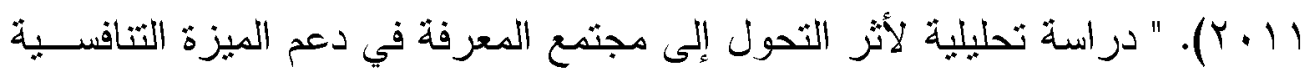
لمؤسسات التعليم العالي بالمملكة العربية السعودية".

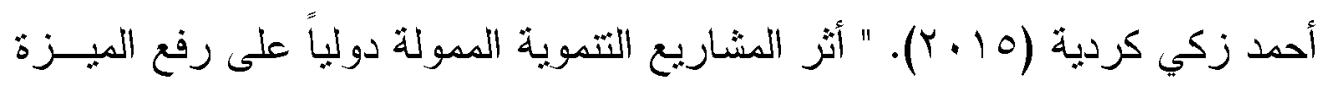

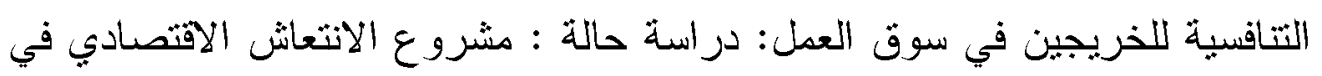

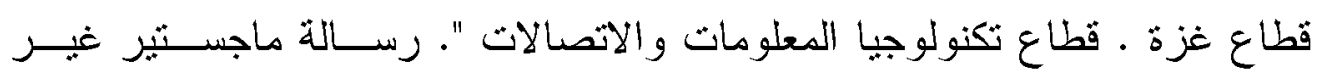
منشورة. قسم إدارة الأعمال. كلية التجارة. الجامعة الإسلامية بغزة.

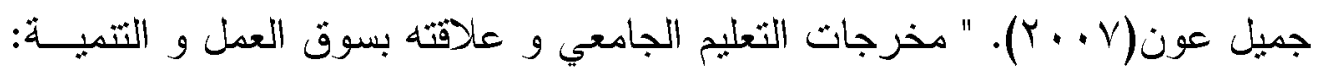
در اسة نظرية نطيقية في البنية الاجثماعية". سلسلة دراسات اجنماعية(ع ()، المركز اليمني للار اسات الاجتماعية و بحوث العمل. الجمهورية اليمنية .

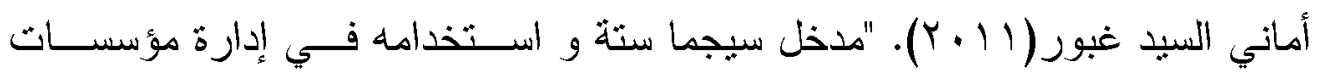

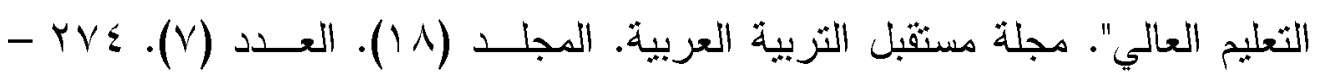
TY

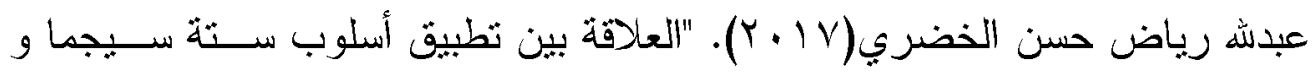
المبزة التتافسية: دراسة مبدانبة على عمادات القبول و التســيل فــي الجامعــات الفلسطينية في محافظات ثطاع غزة". رسالة ماجستير غير منشورة. كلية الاقتصاد

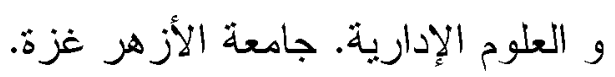




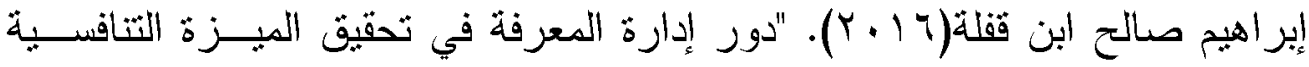
للجامعات اليمنية: دراسة حالة على الجامعات اليمنية بمحافظة حضرموت". رســالة ماجستير غير منشورة. كلية الار اسات العليا. جامعة النيلين. السودان.

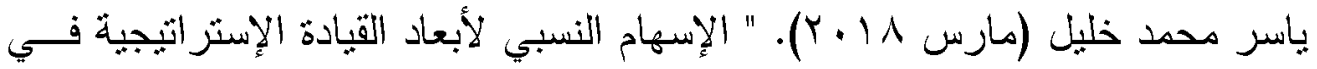
تحقيق الميزة التتافسية للجامعات المصرية". مسثقبل الثربية العربية. المركز العزبي

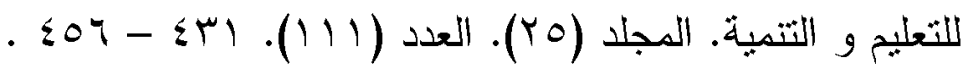

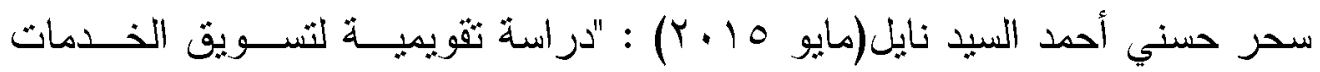
الجامعية في ضوء إدارة الجودة الثاملة بالجامعات المصرية". مجلة دراسات عربية

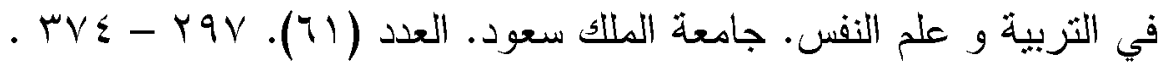

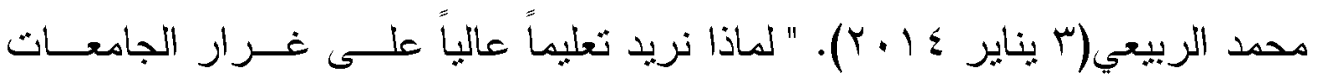

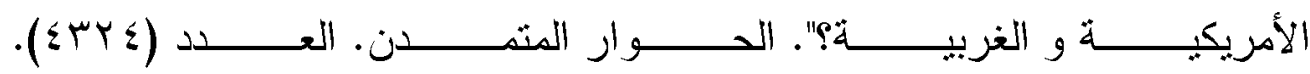

http://www.ahewar.org/debat/show.art.asp?aid=394186

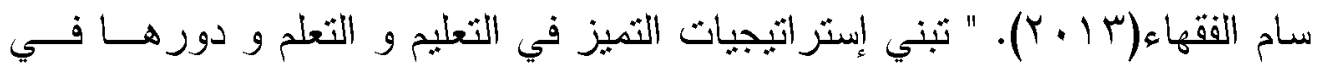
تحقيق الميزة التتافسية المستدامة لمؤسسات النعليم العالي : جامعة النجاح الوطنية : حالة در اسية". المجلة العربية للجودة و الثميز ـ مركز الوراق للار اسات و الأبحاث

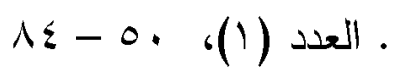

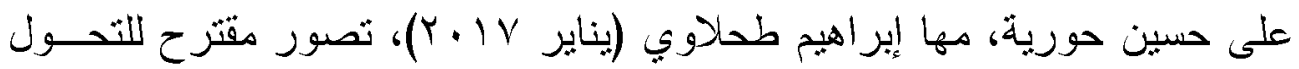
إلى جامعات بحثية في ظل التوجه نحو الاقتصاد المعرفي. مجلة اتحــاد الجامعـات

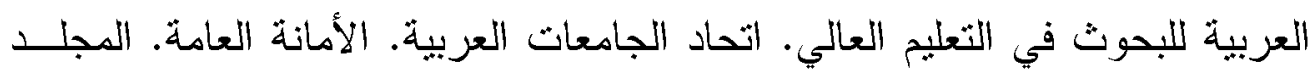

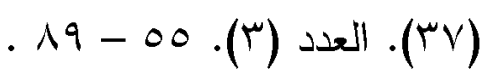

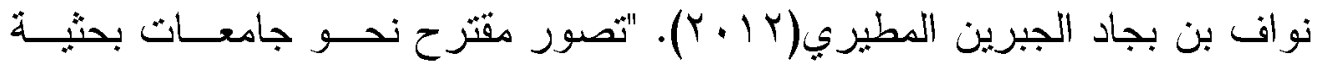
بالتعليم الجاعي السعودي في ضوء تحديات مجتمع المعرفة". رسالة دكتور اة غيــر

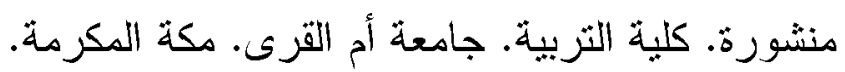




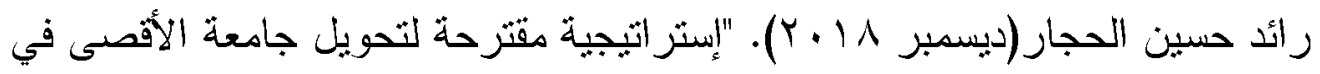

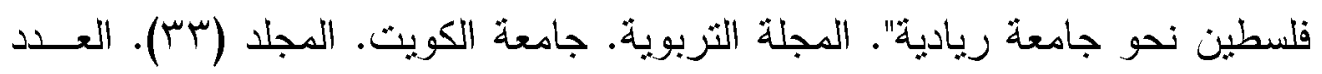

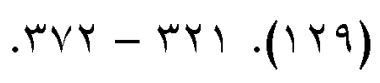

إيمان جمعة محمد عبد الوهاب(1 ( • ب). "مسار ات التحول بمؤسسات التعليم الجامعي

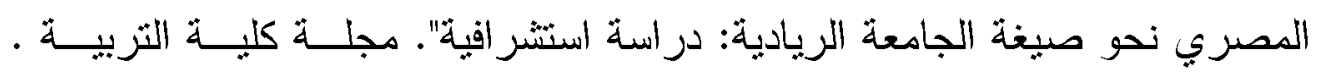

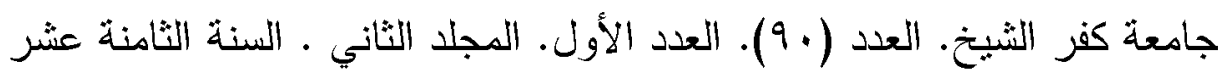

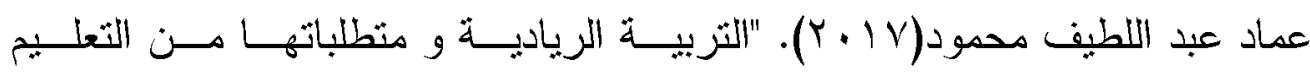
الجامعي". مجلة دراسات في التعليم الجامعي. مركز تطوير التعليم الجامعي. جامعة

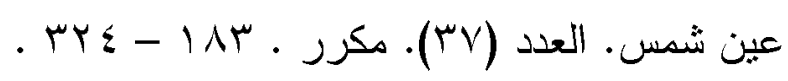

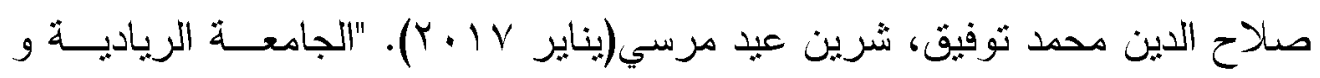

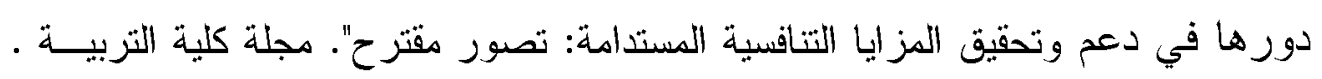

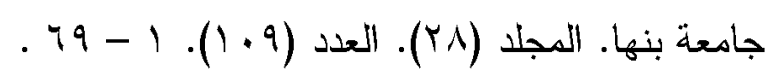

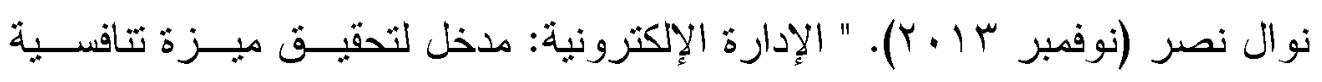

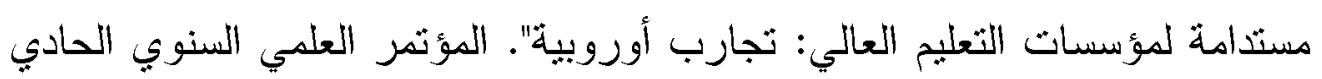
و العثرين: التعليم و التحديث في دول الاتحاد الأوروبي. الجمعية المصرية للتربية

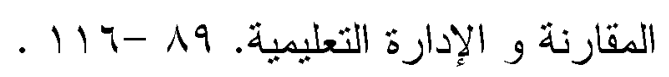

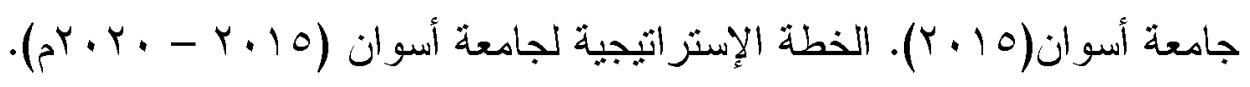

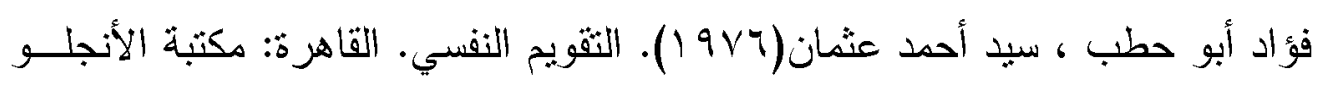
المصرية.

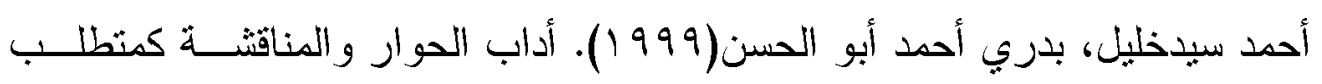

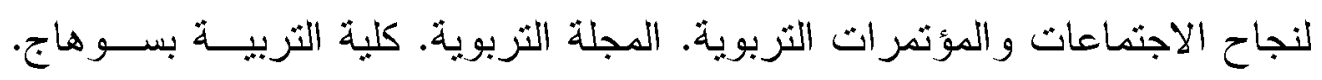
العدد (乏 ( ). (2) 


$$
\text { ثانياً: المراجع الأجنبية }
$$

Horta, Hugo (7 February 2009). "Global and national prominent universities: internationalization, competitiveness and the role of the State". High Educ. No. (58). Pp. 387-405

(https://link.springer.com/content/pdf/10.1007\%2Fs10734009-9201-5.pdf)

Suarez, A., Moreira, R.S. Carrapatoso,E.(2006), «The Role Of Usability In The Competitiveness Of Higher Education Institutions», IADIS International Conference Applied Computing 2006, San Sebastian, Spain, 25-28 February (Available at: http://www.iadisportal.org/digital-library/the-role-ofusability-in-hecompetitiveness-of-higher-education-institutions) Bradmore D. J.(2007). "The Quest of Australian public universities for competitive advantage in a global higher education environment",

A unpublished $\mathrm{PhD}$. Department of management, MIT University, Melbourne Australia.

https://pdfs.semanticscholar.org/b401/f02b81da309faa94f7c36530eed f62a67d27.pdf

Soegoto, Eddy Soeryanto (2009). "Marketing Environment and Source of Competitive Advantage In Terms of Formulating Marketing Strategy and its Influence On Image and Marketing Performance (Survey on Private Universities at Private Higher Educational Institutional Coordinator Area Iv in West Java and Banten Provinces)". Journal of Applied Sciences Research, $5(8)$ :

955-1001. (https://www.researchgate.net/signup.SignUp.html)

Hung, H.\& Lee(2012). "Strategies Management for Competitive Advantage : A Case Study of Higher Technical and vocational education an Taiwan "Journal of higher education policy and management, 34(6). $611-628$.

(Available

https://www.tandfonline.com/doi/abs/10.1080/1360080X.2012.72763 5)

Oana-Mara, S. 2013. "Competitive advantages of HRM practices across top-ranking European universities, 
متطلبات تطوير الميزة التنافسية لجامعة أسوان في ضوء الاتجاهات العالمية المعاصرة

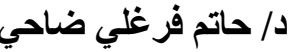

institutional discourse and rethinking HRM strategies in

Romanian Universities", Revista Transylvania de Stiinte administrative, 32 (1), p: 106-127.

https://www.academia.edu/9033105/Institutional_Discourse_and_Rethinking_HRM ROMÂNEȘTI

Porter, M. E. (2001): The competitive advantage of notions .Harvard business review, 68(2), 73-93.

http://www.economie.ens.fr/IMG/pdf/porter 1990-the competitive advantage of nations.pdf

Lombardi, John V.(2011). Quality Engines: The Strategic Principles for Competitive Universities in the Twenty-First Century, The Center for Measuring University Performance.(http://jvlone.com/UCV_ENG_1a.pdf)

Dahan, Gresi Sanje, Senol, Isil (March 2012). "Corporate Social Responsibility in higher education institutions: Istanbul Bilgi University Case". American International Journal of Contemporary Research'. Vol (2). No (3). http://www.aijcrnet.com/journals/Vol_2_No_3_March_2012/10.pdf Khan Hina \& Matly, Harry (2009) 'Implementing service excellence in higher Education ", Education and Training, Volume (51), ISSUE 819.

https://www.emerald.com/insight/content/doi/10.1108/004009109110052 99/full/html

Martin, Angela, Kennedy, Barbara (2006). "Academic service climate as a source of competitive advantage: leverage for university administrators". Education Research and Perspectives, Vol (33). No (1),

(Available at:

https://core.ac.uk/download/pdf/33311839.pdf

Lindawati1, Tuty, Budiman Christiananta, Ellitan, Lena,(January 2014) "Determining Basis For The Position of Competitive Advantage and The Choice OF Strategic Alternatives in widya Mandela Catholic" Social Sciences and Humanities , Faculty of Business, Widya Mandala Catholic University, Surabaya, Indonesia. Vol (5) N. (1). 
https://pdfs.semanticscholar.org/4432/500da69af71f1fc97ec60ce4a1 e6ea413b34.pdf

Mertova, Patricia, Green, Wendy (2010). "Internationalizing teaching and learning: perspectives and issues voiced by senior academics at one Australian university".

(Available at:

http://isana.proceedings.com.au/docs/2010/paper_mertova.p df)

Crow, Michael, Schramm, Carl (2006). "University As Entrepreneur: Ideas That Fly, Ewing Marion Kouffman Foundation, May 23, Pp 1- 9 .

Qi Wang, Ying Cheng, Nian Cai Liu (2012) . "Building WorldClass Universities: Different Approaches to a shared Goal, November 23,

(Available at: www.amazon.com/Building-WorldUniversities-Diffetent.)

Clark, R. B.(2004). "Delineating the Character of the Entrepreneurial Universities" . Higher Education Policy, 17 . $355-370$.

https://link.springer.com/article/10.1057/palgrave.hep.8300062 